University of Louisville

ThinkIR: The University of Louisville's Institutional Repository

Electronic Theses and Dissertations

$12-2017$

\title{
The otaku phenomenon : pop culture, fandom, and religiosity in contemporary Japan.
}

Kendra Nicole Sheehan

University of Louisville

Follow this and additional works at: https://ir.library.louisville.edu/etd

Part of the Comparative Methodologies and Theories Commons, Japanese Studies Commons, and the Other Religion Commons

\section{Recommended Citation}

Sheehan, Kendra Nicole, "The otaku phenomenon : pop culture, fandom, and religiosity in contemporary Japan." (2017). Electronic Theses and Dissertations. Paper 2850.

https://doi.org/10.18297/etd/2850

This Doctoral Dissertation is brought to you for free and open access by ThinkIR: The University of Louisville's Institutional Repository. It has been accepted for inclusion in Electronic Theses and Dissertations by an authorized administrator of ThinkIR: The University of Louisville's Institutional Repository. This title appears here courtesy of the author, who has retained all other copyrights. For more information, please contact thinkir@louisville.edu. 


\title{
THE OTAKU PHENOMENON: POP CULTURE, FANDOM, AND RELIGIOSITY IN CONTEMPORARY JAPAN
}

\author{
By \\ Kendra Nicole Sheehan \\ B.A., University of Louisville, 2010 \\ M.A., University of Louisville, 2012
}

\begin{abstract}
A Dissertation

\author{
Doctor of Philosophy \\ in Humanities
}

Department of Humanities

University of Louisville

Louisville, Kentucky
\end{abstract}

Submitted to the Faculty of the College of Arts and Sciences of the University of Louisville in Partial Fulfillment of the Requirements for the Degree of

December 2017 
Copyright 2017 by Kendra Nicole Sheehan

All rights reserved 

THE OTAKU PHENOMENON: POP CULTURE, FANDOM, AND RELIGIOSITY IN CONTEMPORARY JAPAN

\author{
By \\ Kendra Nicole Sheehan \\ B.A., University of Louisville, 2010 \\ M.A., University of Louisville, 2012 \\ A Dissertation Approved on
}

November 17, 2017

by the following Dissertation Committee:

Dr. Patrick Pranke

Dr. Natalie Polzer

Dr. Steve Sohn

Dr. Michael Hagan

Dr. Delin La 


\section{DEDICATION}

This dissertation is dedicated to my "daughter," Addison Sheehan and my loved ones who have always supported me in my endeavors. 


\section{ACKNOWLEDGMENTS}

As odd as this sounds, I would like to begin by giving thanks to the kami and powers that be for blessing me with all that I have experienced, learned, and gained in this process. Most importantly, I give thanks Dr. Patrick Pranke and Dr. Natalie Polzer for their guidance and abundance of patience. Thanks to committee members, Dr. Steve Sohn and Dr. Delin Lai, for their guidance provided to me in this endeavor. Dr. Mike Hagan also deserves special thanks for joining my committee and always lending an ear to an exasperated student. No words can do it justice, but love and eternal gratitude to my best friend, Stephanie, for her never-ending patience, support, and tolerance for my love of Japan and its culture. She pushed and cheered me on, especially when I was unsure of myself. Love and gratitude to Kazuko Probst, or Kaz-sensei, for her unknowingly pushing me to take my love of Japanese culture seriously as an academic pursuit. In addition, special thanks and consideration are given to Caitlynn Conn and Molly Phelps for being my own "idols" and telling me about Love Live! and all of its magnificence. To Yoko Martin and Chiaki Tamiya 一どうもありがとうございました。Much love and appreciation to Matt Hodge for arguing, debating, and helping me to edit my work.

Finally, I would like to thank my countless other friends and family who have guided me, listened to me whine, cry, complain, and who gave me more support than anyone can deserve. 


\title{
ABSTRACT \\ THE OTAKU PHENOMENON: POP CULTURE, FANDOM, AND RELIGIOSITY IN CONTEMPORARY JAPAN
}

\author{
Kendra Sheehan
}

November 17, 2017

The focus of this dissertation centers on the otaku subculture and their subsequent incorporation of Japanese religious elements into their consumption of Japanese popular culture. This phenomenon highlights the intersections of popular culture and religion in Japan, which is emerging in religious sites. Shintō shrines and Buddhist temples are incorporating popular culture as a means to maintain relevancy, encourage growth of parishioners, and raising revenue by capitalizing on the popularity of manga and anime. The relevance of this research connects to the continued impact of Japanese popular culture. Through globalization, Japan leads as a soft power, ranking third among world economic powers. The heavily promoted concept of Cool Japan, by the government and businesses, is aligned with otaku interests, relating to anime, manga, and video games. The irony of Cool Japan is that the otaku are disregarded within Japanese society as undesirables.

The first chapter provides a theoretical background examining this socio-religious phenomenon, and sociological framework, which considers the capitalist economy and relationship to religion. Chapter Two defines Shintō and kami, explains deification, outlines an historical overview for religion in Japan, providing historical antecedents for 
the otaku's relationship to religion and highlighting historical and cultural influences. This chapter provides a summary history of illustrated narrative, how it presages contemporary anime and manga, and its convergence with religion and popular culture.

Chapter Three analyzes the historical and cultural contexts that form the otaku identity, traces the etymology of the word "otaku," and positions the otaku within mainstream society. This chapter incorporates social psychology and identity theory to analyze and interpret how the otaku form identities, categorize, and define themselves. This analysis of otaku identity and mindset provides insight into the otaku's consumptive behaviors associated with popular culture. Chapter Four analyzes the otaku's consumptive practices and behaviors associated with anime and manga, and their impact on four Shintō shrines and two Buddhist temples. Chapter Four concludes with the emergence of "pop culture kami" that accentuate the otaku's incorporation of Shintō elements into their consumption of popular culture. This convergence of otaku, religion, and popular culture points to emerging shifts within contemporary Japan. 


\section{TABLE OF CONTENTS}

PAGE

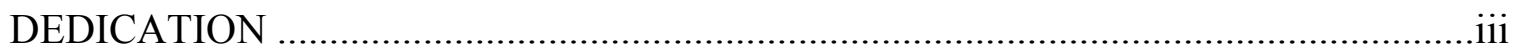

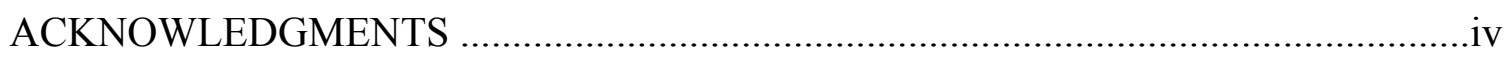

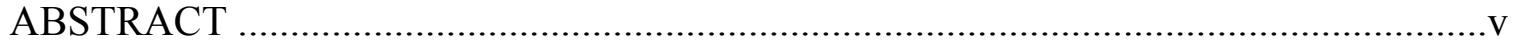

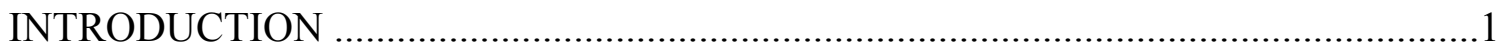

I. Japan as a Soft Power ……………..........................................................

II. Otaku Culture and Cool Japan ......................................................................

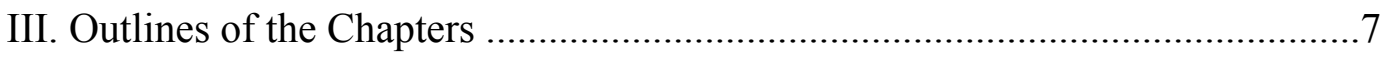

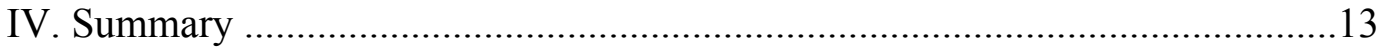

CHAPTER ONE: THEORETICAL FRAMEWORKS AND APPLICATIONS OF

THEORY

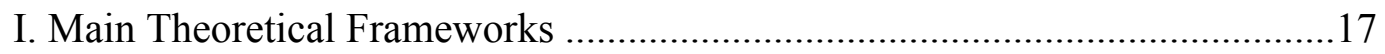

1. Religious Influences in Shaping a Capitalist Society.............................18

2. Pursuit of the Calling in Commodifying Japanese Culture ...................20

3. Creation of Specialist Groups in a Capitalist Society ...........................21

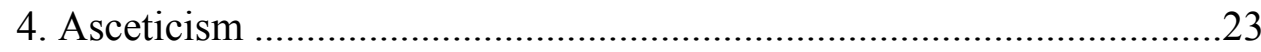

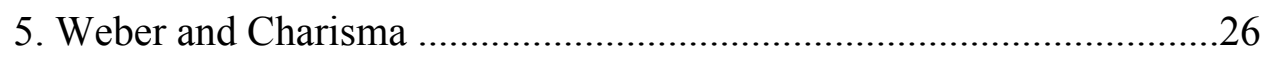

II. Social Construction of Religious Experience …………….............................30

III. Social Psychology and Identity Theory ………………...................................34

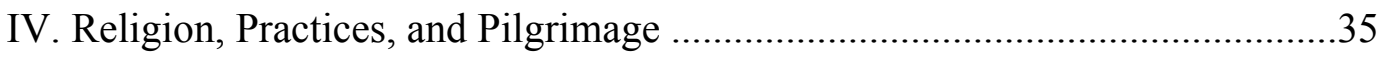


V. Other Points of Discussion 38

VI. Conclusion

\section{CHAPTER TWO: HISTORICAL AND CULTURAL CONTEXTS OF RELIGION IN}

JAPANESE CULTURE

I. Historical Roots of Manga ......................................................................45

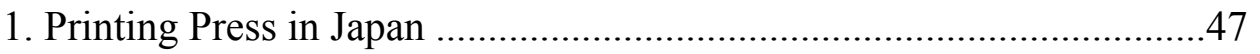

2. Ukiyo-E and Coining a Term .....................................................48

3. Nineteenth Century Japan and the Creation of Manga Magazines .......50

4. Media as a Tool during the Rise of Fascism and Nationalism ............52

5. Manga and Anime in Postwar Japan ...............................................54

6. Manga for the Mature Reader.......................................................56

7. Manga and Anime during and after the Bubble Economy of the

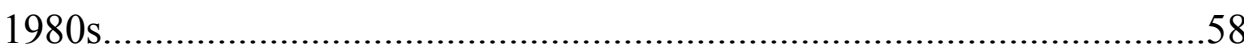

8. Anime and Manga's Influence on Contemporary Japan .....................60

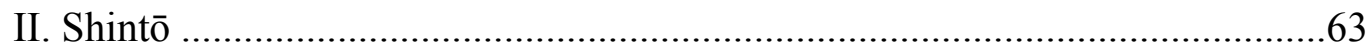

1. Routinization of Shintō in Pre-Meiji Japan .....................................64

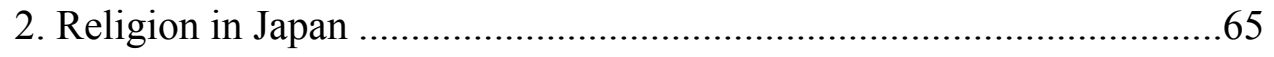

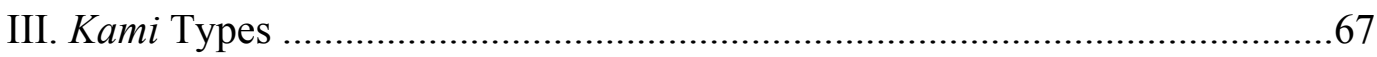

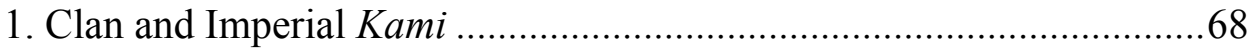

2. Nature and Natural Kami .......................................................... 71

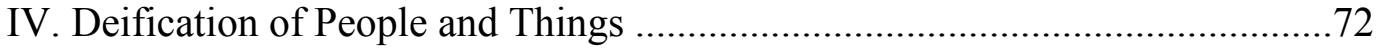

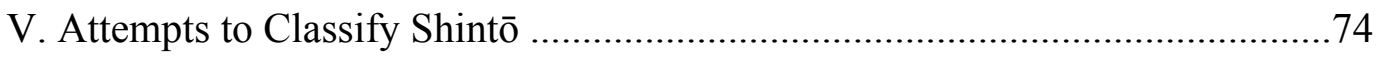

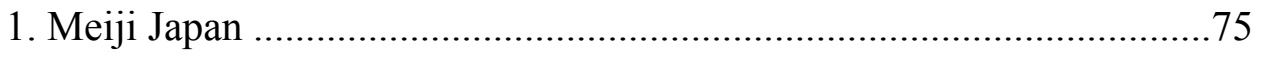

2. World War II and Postwar Japan ................................................. 79 
3. Formation of New Religions and New-New Religions .82

VI. Otaku: Marking the Transition from the Profane to the Sacred .85

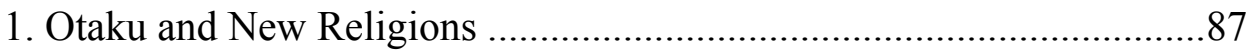

2. Otaku and Pop Culture Figures ..................................................91

VII. The Emperor of Japan: Transitions of the Sacred to the Profane .................93

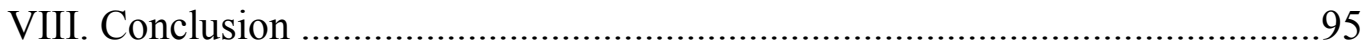

CHAPTER THREE: UNDERSTANDING THE OTAKU MIND: OTAKU HISTORY

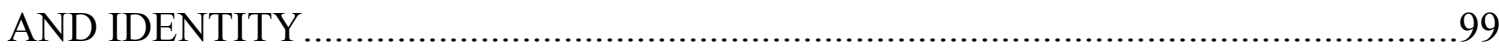

I. Etymology and Origins of the Word "Otaku" ............................................100

1. Historical Overview of the Otaku.................................................. 102

II. Understanding and Perceptions of the Otaku ............................................. 106

III. Identity Theory and the Formation of the Otaku Identity ...........................117

IV. Understanding the Connection of Religious Elements to Otaku Identity and

Behaviors 124

V. Conclusion

CHAPTER FOUR: FROM FETISHIZED ICON TO POP CULTURE KAMI: OTAKU INCORPORATION OF RELIGIOUS ELEMENTS WITH POP CULTURE ...............131

I. Otaku: Typical Fans Versus Excessive Consumers ...................................132

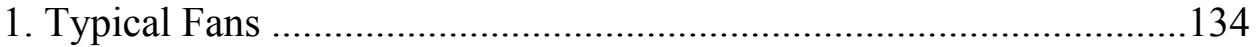

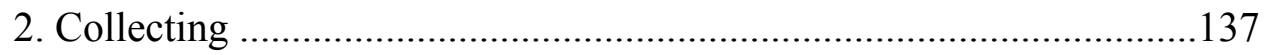

3. Pop Idols and Excessive Consumers ................................................139

II. Passion and Devotion through Moe .......................................................141

1. Kawaii Mascots in Japan: Evoking an Emotional Response ..............144

2. Points of Comparison to Other Religious Forms of Devotion ............148 


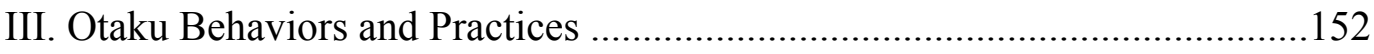

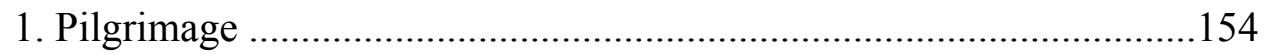

1.1 Observations at the Washinomiya Shrine ..........................162

2. Shopping and Spending ......................................................... 163

3. Establishing Space and Intimacy .............................................. 171

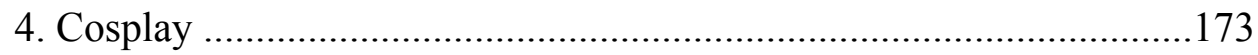

5. Devotional Practices .................................................................. 174

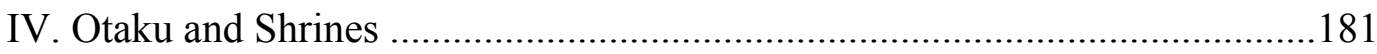

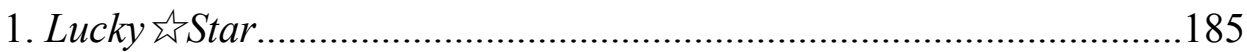

2. Love Live! ........................................................................................ 188

3. Shrines and Pop Culture ............................................................... 191

V. Pop Culture Kami ................................................................................... 196

VI. Conclusion ….................................................................................20

1. Otaku Generations......................................................................202

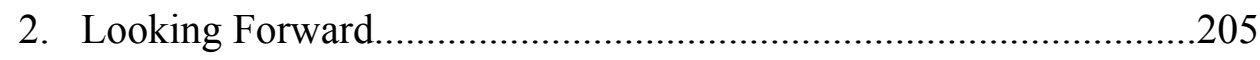

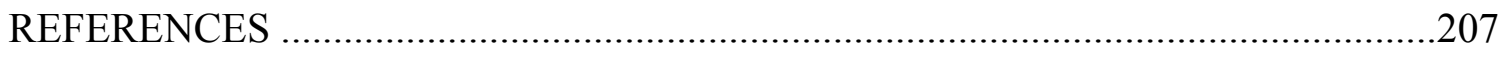

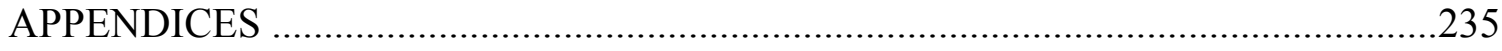

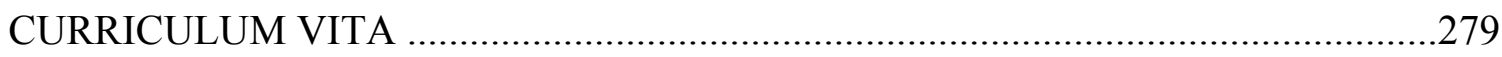




\section{INTRODUCTION}

Popular culture can sometimes be considered mindless entertainment that is massproduced and mass consumed, but it can also provide meaning and contribute to the human experience. Each country has its own form of popular culture, which is often categorized in terms of entertainment media, such as film and music. Examining popular culture can present a new lens with which to critically analyze culture. One of the most largely consumed forms of popular culture, in terms of animated entertainment, comics, and video games, comes from Japan.

In my own research into Japanese popular culture, I began to notice common themes in anime, or Japanese animation, and manga, Japanese comics. The themes, plots, and character development stood out to me as being entirely different from Western works. Religion appeared in many of these Japanese works, often without being explicitly pointed out, in a taken for granted manner. Other non-Japanese scholars who notice similar themes within Japanese texts, however, these scholars focused on elements within specific works. This is evidenced in the scholarship of Mark MacWilliams who focuses on religion in manga, or how Japanese popular culture draws from Japanese traditions as discussed in Jolyon Baraka Thomas’ Drawing on Tradition: Manga, Anime, and Religion in Contemporary Japan. What I noticed moved beyond the popular culture artifacts and connections to religion in general, into a closer examination of the people consuming them. Internet message boards like 2channel and blogs like LiveDoor highlighted posts or blogs where the fans of anime and manga, known as the otaku, posted images of shrine- 
like arrangements of figurines, images, and food, in addition to making references to certain anime and anime characters as "kami." In Japanese, kami can refer to the deities of Shintō or the spirits that are all around us in nature. ${ }^{1}$

This dissertation examines the incorporation of religious elements by the otaku in their consumption of Japanese popular culture. In my research I discovered that these consumptive behaviors and ritual-like practices point to an emerging impact on at least four Shintō shrines and two Buddhist temples within Japan. These are the Chichibu Shrine, Ōmi Shrine, Ryōhō-ji Temple, and Jōrin-ji Temple, with close examinations of the Washinomiya and Kanda shrines. The convergence of religious elements and the otaku phenomenon are resulting in ritualization of otaku behavior with religious motifs and a small number of shrines and temples are beginning to respond to this. The otaku visit these shrines and temples in "anime pilgrimages" to visit the locations that are associated with their favorite anime and fictional characters. A symbiotic reciprocal relationship between these four shrines and two temples has grown out of the otaku anime pilgrimages due to their association with certain anime. Two Shintō shrines that highlight this growing socio-religious phenomenon are the Washinomiya Shrine and its

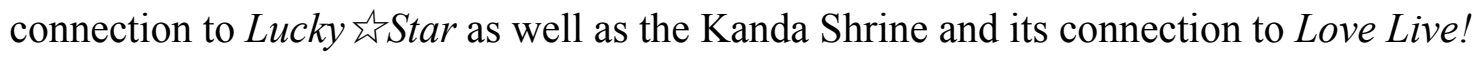

The reason for my research was to investigate and find an answer for this emergent socio-religious phenomenon. As I have researched this topic, I began to realize that the subject matter of my research shifted from examining otaku and popular culture to illustrating the significance of this intersection of popular culture and religion within Japan. Examining Japanese popular culture offers new perspectives on historical and

\footnotetext{
${ }^{1}$ Sokyo Ono, Shintō: The Kami Way, Rutland: Tuttle, 1962, 6-8.
} 
cultural contexts within Japan. For instance, looking at popular media that offers the perspectives of a middle class society that had to rebuild in the aftermath of WWII Japan during the 1950 s.

\section{JAPAN AS A SOFT POWER}

American political scientist Joseph Nye of Harvard University coined the concepts of soft and hard power. A hard power was described by Nye as the ability to use "economic and military might to make others follow your will," while soft power "is the ability to get what you want by attracting and persuading others to adopt your goals." ${ }^{2}$ In an age of globalization, contact with other cultures is inevitable. Japan, once a budding hard power during the 1980s with its success in the automotive industry and electronics, eventually became a soft power following the economic Bubble Burst of $1991 .^{3}$ In spite of the economic bubble bursting, Japan remains the third largest economy in the world. Within Japan, there has been a conscious shift by the government and businesses to capitalize on soft power rather than hard power given the stagnation of the continued economic recession in Japan. Although Japanese popular culture had been present throughout the globe following World War II, the use of the Internet and quickly dissipating global boundaries made it easier for Japanese popular culture to spread to anyone with access to the World Wide Web, social media, or a smartphone.

Japan is considered one of the leading soft powers in the world, as has been

\footnotetext{
2 Joseph Nye, “Propaganda Isn't the Way: Soft Power,” International Herald Time, 10 Jan. 2003, Web, 13 Oct 2017. <https://www.belfercenter.org/publication/propaganda-isnt-way-soft-power>

${ }^{3}$ During the 1980s, Japan had a growing economic bubble which was marked by rapid economic growth. In 1991, the stock market in Japan crashed, businesses went bankrupt, and the bubble "burst." See Eric Johnston, "Japan's Bubble Economy: Lessons from when the Bubble Burst," The Japan Times, 6 Jan 2009 , Web, 18 Nov 2017. <https://www.japantimes.co.jp/news/2009/01/06/reference/lessons-from-when-thebubble-burst/\#.WhGZ4BNSyRs>
} 
argued by many scholars, such as Douglas McGray ${ }^{4}$ and William M. Tsutsui. ${ }^{5}$ Many countries, not just the United States, enjoy Japanese pop culture at some level or another, whether it is through video games, television, or even horror films. ${ }^{6}$ When Pokémon was released in the West in 2001, it became a worldwide phenomenon, a successful franchise for video game company Nintendo, one that has managed to maintain popularity. ${ }^{7}$

There are many online streaming sites, such as Crunchyroll, which simultaneously release series online for the English-speaking world as they are being released in Japan. The growth of technology has impacted not only the transmission of Japanese popular culture, but also fandom subcultures, such as the train otaku, and religious sites, such as the Washinomiya and Kanda shrines, which are the focus of this dissertation. It is not uncommon to find some Shintō shrines and Buddhist Temples that may have anime mascots, as well as selling items emblazoned with figures from pop culture on shrine and temple grounds. Often times, the popular culture being used at these shrines and temples can be considered a part of "otaku culture." With the spread of globalization and relative ease of access to the Internet, popular culture from Japan is increasingly influenced by what is popular with otaku in Japan. This influence is evidenced in the creation of "Cool Japan" which gained approval by the Japanese government and businesses. The simplest definition of this term refers to the things from Japanese culture that are deemed "cool" and worthy of promoting overseas for tourism and business.

\footnotetext{
${ }^{4}$ See Douglas McGray, “Japan’s Gross National Cool,” Foreign Policy 130 (2002): 44-54.

${ }^{5}$ See William M. Tsutsui, Japanese Popular Culture and Globalization, Ann Arbor: Association for Asian Studies, Inc., 2010.

${ }^{6}$ More recently, since 2013, Korean television dramas and pop music have begun to grow in popularity, as witnessed by the rise of Korean rapper Psy's "Gangnam Style." Despite the rising popularity of Korean music and drama, Japan still currently dominates as a soft power in a global world through its animation, comics, video games, and film.

${ }^{7}$ See Stephen Kline, Nick Dyer-Witherford, and Greig de Peuter, "Pocket Monsters: Marketing in the Perpetual Upgrade Marketplace," Digital Play: The Interaction of Technology, Culture, and Marketing, Quebec City: McGill-Queen's University Press, 2003, 218-245.
} 


\section{OTAKU CULTURE AND COOL JAPAN}

This concept of Cool Japan is ironically associated with the "uncool" otaku. The otaku are recognized as "losers" or the undesirables of Japanese society, and at the same time they are influential on the ideas and concepts of Cool Japan. Cool Japan is selfconsciously inspired by otaku culture but at the same time the otaku are not fully accepted by mainstream Japanese society. Otaku culture is associated with Japanese popular culture as it pertains to comics, animation, and video games. Eiji Ōtsuka refers to otaku culture as "manga, anime, games, related merchandise and personages, and fan activities surrounding them." ${ }^{\prime 8}$ The rising popularity of anime, manga, and video games outside of Japan eventually caught the attention of not just scholars but government officials and other leaders within Japan. In 2002, Douglas McGray wrote an article in Foreign Policy entitled “Japan's Gross National Cool," discussing Japan's growth as a soft power, which in turn was reevaluating what it meant to be a world superpower, and thus coining the term "Cool Japan."

Notably, the success of franchises such as Pokémon resulted in articles such as those by the Washington Post in 2003 and the BBC in 2004, further highlighting Japan's growing reliance on "cool culture." ${ }^{10}$ Many businesses and media in Japan began to capitalize on the idea of "Cool Japan," promoting it through various means. Major Japanese network Nippon Hōsō Kyōkai (NHK) (Japan Broadcasting Corporation) began airing Cool Japan Hakkutsu: Kakkoii Nippon!, known in the West as Cool Japan, which

\footnotetext{
${ }^{8}$ Eiji Ōtsuka, "Otaku Culture as 'Conversion Literature,"” Debating Otaku in Contemporary Japan: Historical Perspectives and New Horizons, Eds. Patrick W. Galbraith, Thiam Huat Kam, and Björn-Ole Kamm, London: Bloomsbury Academic, 2015, xiv.

${ }^{9}$ Douglas McGray, “Japan's Gross National Cool," Foreign Policy 130 (2002): 44-54.

${ }^{10}$ See Anthony Faiola, “Japan's Empire of Cool," Washington Post, 27 Dec 2003, Web, 13 Oct 2017. $<$ https://www.washingtonpost.com/archive/politics/2003/12/27/japans-empire-of-cool/ablae69f-756a487c-8b34-2823072f342a/?utm_term=.478b33026c1d > S See also "Japan Counts on Cool Culture," BBC, 13 Dec 2004, Web, 13 Oct 2017. <http://news.bbc.co.uk/2/hi/business/4092461.stm>
} 
featured foreign guests who would be exposed to numerous facets of popular culture. Despite Cool Japan being used unofficially throughout the 2000s, it was officially recognized in 2010 when the Ministry of Economy, Trade and Industry began to actively promote "Cool Japan." More often than not, "Cool Japan" often features anime and manga styled mascots beckoning visitors to purchase goods that feature the mascots' image. Small towns capitalize on the ideas in like manner, especially when real life locations are featured in anime and often result in otaku and non-otaku visiting.

Most recently, during the 2016 Summer Olympics in Rio de Janeiro, Brazil, Japanese Prime Minister Shinzo Abe appeared at the closing ceremony dressed as wellknown video game character Mario (Nintendo's Super Mario Brothers). While some, such as Nancy Snow ${ }^{12}$ and Japanese musician Gackt, ${ }^{13}$ have been critical of the Cool Japan Initiative, there is no doubt that Japan is benefitting from using otaku culture to propagate a "cool" Japanese culture that is markedly different from WWII era Japan. Tokyo will be the site for the 2020 Olympics, and Prime Minister Abe's appearance at the 2016 Rio Olympics points to the use of Cool Japan for both tourist purposes and possibly political ones. This is undoubtedly interesting when one considers that Prime Minister Abe is not known for pop culture references like former Prime Minister Tarō Asō. Not to mention, that at the end of his appearance, Prime Minister Abe released a red

\footnotetext{
11 “Promoting 'Cool Japan,' The Japan Times, 15 Aug 2010, Web, 2 Feb 2016. $<$ https://www.japantimes.co.jp/opinion/2010/08/15/editorials/promoting-cool-japan/\#.WeD1YtOGORs>; See also "Establishment of the Creative Industries Promotion Office," Ministry of Economy, Trade and Industry, 8 June 2010, Web, 31 Jan. 2016. <http://www.meti.go.jp/english/press/data/20100608_01.html>

${ }^{12}$ See Nancy Snow, "Uncool Japan: Japan's Gross National Propaganda," Metropolis, 8-21 Nov 2013, 30.

13 "Gackt Lashes Out at Cool Japan: 'Almost No Results of Japanese Culture Exported Overseas," Japan Today, 6 Jul 2015, Web, 19 Nov 2017. <https://japantoday.com/category/entertainment/gackt-lashes-out-atcool-japan-almost-no-results-of-japanese-culture-exported-overseas $>$
} 
ball clearly representing Japan, the "land of the rising sun."14 Thus, Cool Japan

commodifies otaku culture to not only make money but to also project a carefully crafted image of a peaceful and fun loving Japan.

The otaku have undoubtedly had an influence on Japan in more ways than one. This dissertation will focus on their relationship to not only popular culture, but the religious influences that they incorporate into their consumption of popular culture and how it is beginning to impact Japanese religious sites, notably the four Shintō shrines out of 80,000 shrines and two Buddhist temples out of 77,000 temples that my research has discovered thus far. ${ }^{15}$ Furthermore, I want to consider the implications of otaku culture being promoted so actively by the government, businesses, and religious sites, especially when it is incorporating not only religious elements, but traditional aspects of Japanese culture as well.

\section{OUTLINES OF THE CHAPTERS}

Chapter One: Theoretical Frameworks and Applications of Theory sets up two goals which are 1) to reevaluate the role of religion and popular culture in society as evidenced through otaku subculture in Japan, and 2) to lay the framework for illustrating how the otaku are exercising an influence on a small number of shrines and temples. This chapter provides a brief introduction to the following chapters and notes the critical frameworks and theories that inform the dissertation. Chapter One summarizes the arguments from prominent theories being used to analyze the particulars of the otaku and their subculture's relationship to Japanese religion. The theories discussed and outlined in

\footnotetext{
14 “Tokyo 2020 Clues: When Japan's PM Dressed Up as Mario,” BBC News, 22 Aug 2016, Web, 20 Nov 2017. <http://www.bbc.com/news/world-asia-37151800>

${ }^{15}$ See "Q\&A," Association of Shintō Shrines, n.d., Web, 27 Oct 2017.

$<$ http://www.jinjahoncho.or.jp/en/faq/>; See also Takashi Hasegawa, "Buddhist Temples in Japan are in Crisis," Toyokeizai Online, 17 Aug 2015, Web, 27 Oct 2017. <http://toyokeizai.net/articles/-/80746>
} 
this chapter are drawn from sociology, social psychology and identity theory, religious history, fandom studies, anthropology, and Japanese cultural critics and scholars.

In particular, Chapter One considers Max Weber's ideas concerning the processes of religion, rationalization, and secularization in association with the rise of capitalism. Weber's goal in The Protestant Ethic and the "Spirit" of Capitalism and other Writings, was "to establish whether and to what extent religious influences have in fact been partially responsible for the qualitative shaping and the quantitative expansion of that 'spirit' across the world, and what concrete aspects of capitalist culture originate from them." "Weber's focus was a Western and Christian viewpoint, but his correlation of religious "spirit" and capitalism is beneficial for examining the otaku's relationship to religion and Japanese society. With regard to the processes of religion, Weber has three ways in which to study economic events and religion; 1) economic events and institutions, 2) economically conditioned phenomena, and 3) economically relevant phenomena. ${ }^{17}$ This dissertation is focusing on the study of an economically relevant phenomena, the otaku and Japanese religion, which "are not economic in any orthodox sense of the term but that [are] pertinent for our understanding" of the impact of religion in Japan, and the relationship between the otaku and their impact on the economy and religion. ${ }^{18}$ Therefore, Weber's theories and frameworks were useful for organizing and analyzing this emerging socio-religious phenomena, the otaku, and they have incorporated their behaviors, specific Japanese religious practices, and how this is capitalized in their consumeristic behavior within Japan. The otaku are combining

\footnotetext{
${ }^{16}$ Max Weber, The Protestant Ethic and the "Spirit" of Capitalism and other Writings, Trans. Peter Baehr and Gordon C. Wells, New York: Penguin Books, 2002, 36.

${ }^{17}$ Max Weber, The Protestant Ethic, xxxvi.

${ }^{18}$ Max Weber, The Protestant Ethic, xxxvi.
} 
religious elements with their consumeristic behaviors and there are a small number of shrines and temples taking notice of and participating in this emerging capitalistic arrangement that encourages otaku and mainstream consumers of popular culture to visit the shrines and temples. This dissertation's use of Weber is relevant for examining this relationship between religion and capitalism, and is not trying to prove or disprove Weber.

Chapter Two: Historical and Cultural Contexts of Religion in Japanese Culture outlines a historical overview of Japanese religion from the ancient period to the contemporary period. Outlined in this chapter are the fluctuations of political powers and their influences on religion in the pre-modern period, the development of mass media, and the beginning of visual culture and manga in the modern period. An investigation of the historical roots of manga and anime points to antecedents of illustrated narratives prior to the modern period and the development of the otaku. By tracing the development of Japanese illustrated narrative, the emergence of the otaku, and the confluence of religion and visual culture are demonstrated. This development is discussed in several stages: 1) illustrated scrolls from the Heian period (794-1185 CE) depicted scenes from literature, such as the Tale of Genji, and the development of a printing press which massproduced Buddhist sūtras in the eleventh century to the mid-seventeenth century; 2) the creation of mass-produced woodblock prints in the Tokugawa period (1600-1868 CE) that depicted everyday scenes from middle-class life and theatre; 3 ) the emergence of comic magazines in the Meiji period (1868-1912 CE) which evolved from Western inspired satirical magazines to comic magazines for children; 4) the rise of ultranationalism and fascism in the 1930s during the Shōwa period (1926-1989 CE), 
resulting in illustrated media and animation being used for propaganda; 5) the historical and cultural contexts of comics in postwar Japan depicting the everyday lives of the Japanese during and following the U.S. Occupation of Japan (1945-1952 CE); 6) how comics and animation shifted in subject matter resulting in a focus on drama and serious themes in the late 1950 s to the $1970 \mathrm{~s} ; 7$ ) the impact of rapid economic growth, referred to as the Bubble Economy, in the 1980s and shifting subject matters in the 1990s in comics and animation; and 8) the influence of animation and comics in contemporary Japan. This outline provides background into the intersection of illustrated media with Shintō in the twentieth century.

Chapter Two defines Shintō and describes the role of kami in the lives of the Japanese people. Also analyzed and described are the ways in which kami are classified and the deification of natural objects, human beings, and manmade things. Shintō is one of the main influencing religions, but other religions, specifically Buddhism, are discussed due to their influences that helped to shape Japan during numerous historical points. Featured in this chapter are the ambiguous boundaries between the sacred and profane in Japan, noting how they shift throughout history. The sacred is religious, manifesting itself as something that is "a power" and "reality." 19 The profane is the opposite of the sacred, being a part of the normal and non-religious world. ${ }^{20}$ These shifts are examined through analysis of the otaku and their role in influencing a transition from non-religious (i.e. profane) things to a religious-like reverence (i.e. sacred). In short, how things that are sacred in one generation lose their sanctity in another generation, as well as how things begin as profane objects that become deified and sacred.

\footnotetext{
${ }^{19}$ Mircea Eliade, The Sacred and the Profane: The Nature of Religion, Trans. Willard R. Trask, Orlando: Harcourt, Inc., 1987, 10-13.

${ }^{20}$ Mircea Eliade, The Sacred and the Profane, 10-13.
} 
Chapter Three: Understanding the Otaku Mind: Otaku History and Identity provides a historical overview of the otaku as an identifiable and identified group, the etymology of the word "otaku," and how otaku identity is formed. This chapter examines cultural and historical contexts that influenced the perception of otaku, as well as the development of their subculture within Japan. The discussion of these cultural and historical contexts incorporates and evaluates the popular depictions and stereotyping of otaku in media. Addressed within this chapter are Japanese societal expectations and how the otaku navigate or circumvent society through the medium of online communities. Social psychology and identity theory, such as the work of John C. Turner, are used to inform the investigation of how otaku form their own identity distinct from non-otaku in Japan. Turner notes that "social identity processes are fundamental to understanding collective behavior," and Japan is considered a collective society and Turner's work is beneficial to understanding how the otaku create their identity and define themselves against Japanese society. ${ }^{21}$ Critiques of otaku lifestyles and commentary from Japanese cultural critics and scholars offer Japanese perspectives on the otaku. Chapter Three looks closely at the connections of religious elements to otaku identity and behavior, such as the food offerings to images of their favorite anime or manga characters. Additionally, this chapter considers the influence and impact of the otaku on the economy and culture of Japan, including an examination of the influence of otaku on tourism and government initiatives, such as the creation of "Cool Japan." Japanese society and its government are playing a role in constructing the otaku identity from the outside. The otaku actively participate in the construction of their own identity, which, in turn, is impacted and

\footnotetext{
${ }^{21}$ John C. Turner, "Some Current Issues in Research on Social Identity and Self-Categorization Theories," Social Identity: Context, Commitment, Content, Eds. Naomi Ellemers, Russell Spears, and Bertjan Doosje, Oxford: Blackwell, 1999, 6-7.
} 
constructed by the identity impinging on them from the outside.

Chapter Four: From Fetishized Icon to Pop Culture Kami: Otaku Incorporation of Religious Elements with Pop Culture looks at otaku behavior and practice as it relates to two Shintō shrines and one Buddhist temple that have been influenced by the otaku and popular culture. Initial discussion illustrates the distinction between "typical fans" and the otaku, who are stereotyped in Japan as "excessive consumers." Within this exploration is a close examination of the otaku's collecting behaviors and how far some otaku will go to be close to their favorite pop culture figure, a fictional being such as an anime character or a human being, such as a pop singer. The concept of moe is discussed to provide a background for understanding the otaku's passion concerning their favorite pop culture figures. The role of anime-themed mascots in advertising follows an explanation of moe, which refers to the passion that an otaku has for characters that are often depicted with certain character traits, such as being clumsy or cute. This otaku aesthetic has affected at least one Buddhist temple in its creation of a mascot to lure in more temple parishioners. The otaku behaviors and practices analyzed are pilgrimage, shopping and spending, establishing space and intimacy, cosplay, and specific devotional-like otaku behaviors that mimic traditional Japanese ritual practices. The four Shintō shrines and two Buddhist temples examined in Chapter Four illustrate the relationship between otaku and religion, noting the impact and use of popular culture by both shrines. For instance, how these shrines and temples, use popular culture as a means to maintain relevancy for and to encourage more parishioners. The concluding section discusses how the otaku's pop culture figures have emerged for them as pop culture kami that accentuate the otaku's incorporation of Shintō elements into their consumption of popular culture. 


\section{SUMMARY}

One caveat that should be mentioned is that my research into otaku culture is not representative of all Japanese or even those who consider themselves "otaku," as there are many subcategories and types of otaku. I also want to point out that this dissertation is not meant to be a criticism of otaku or Japan itself, rather its meant to bring attention to a socio-religious phenomenon that I have noticed in my research and own consumption of Japanese popular culture. While reviewing my evidence and analysis, one should consider the Japanese cultural ideas of honne and tatemae. These terms refer to the idea of showing one's true emotions or self versus a façade that is appropriate only in public. ${ }^{22}$ When interviewing an otaku or non-otaku, there arises the issue of whether the person is showing a true face, honne, or if they are providing the answers that they think the interviewer wants to hear, tatemae. Another thing to consider is that a Westerner who arrives in Japan may be considered an outsider until they have spent more than several years in the country, and still possibly be given careful answers about the cultures and traditions of the country. My own research was limited to one month spent in Japan, during May 29, 2016 to June 27, 2016, traveling to the cities of Nara, Tokyo, Kyoto, and Hiroshima. Much of my research was gathered through conversation, short interviews, and firsthand experience of the Washinomiya Shrine, Akihabara, and the Kanda Shrine.

With these things in mind, one of the goals of this dissertation is to open discussion about the power and effects of popular culture within religion and other cultures. As technology and trends are constantly changing, it is possible that by the time one reads this dissertation, a new anime series may be occupying the minds of those who

\footnotetext{
22 See Boye Lafayette De Mente, The Japanese Have a Word for It: The Complete Guide to Japanese Thought and Culture, Lincolnwood: Passport Books, 1997, 6-7.
} 
consume it. Even years from now, the otaku subculture may shift from its current state to an entirely new state that is positively accepted in Japanese culture or even completely removed. Whichever the case, this socio-religious phenomenon warrants examination as a reflection of current shifting relationships between the secular and sacred in Japan. 


\section{CHAPTER ONE: THEORETICAL FRAMEWORKS AND APPLICATIONS OF}

\section{THEORY}

In the twenty-first century, cities and their populations around the world exist within media-saturated spheres. All economic classes are influenced by consumerism and commodification as items, through marketing, are promoted as desirable products, and advertising urges them to be purchased and consumed. A modern, high-tech country like Japan is no exception, but consumerism in Japan arguably takes unique forms with no Western equivalent. A primary example is a group of consumers sometimes regarded as a subculture, known as otaku. For now, they can be described as predominantly male consumers of items associated with popular cartoons, videogames, and comics. ${ }^{23}$ They not only purchase these items, but care for them with a certain reverence incomparable to Western fandom consumers. Western and typical fans purchase items associated with their favorite franchises. They may purchase multiple copies of special edition DVDs or books, wait in line to meet voice actors or creators, and/or contribute to an ever-growing body of fan-produced works.

The otaku, nonetheless, are more than mere fans. They engage in what are considered normative fandom behaviors, such as consuming popular media, creating fan works associated within the target media, and supporting the creator or studio that produces the target media. Yet, over and above these assumed normative behaviors, the otaku's fan experience is shaped by the Japanese society in which they live, a society

\footnotetext{
${ }^{23}$ The otaku will be discussed at greater length in Chapters 3 and 4.
} 
heavily influenced by rigid societal structures and traditions deeply rooted in Japanese culture and subsequently linked to religious tradition. Although there is no official statistical data, it can be assumed that the otaku make up a small portion of the total Japanese population. The otaku has conflicting reputations within Japanese society because they exercise influence on Japanese culture, the economy, and the pop culture they consume despite being somewhat ostracized by Japanese society. A goal of this dissertation is to reevaluate the role of religion and popular culture in society as evidenced through otaku subculture.

With these elements in mind, the otaku can be examined using many critical frameworks. Historicism, sociology, anthropology, and fandom studies are just a few of the ways with which to examine this group. This dissertation will first review and explain relevant theoretical frameworks in Chapter One, then move on to Chapter Two which outlines a historical basis for how religion, religious power, and the role of the kami fluctuate throughout Japan's history. Chapters Three and Four provide a closer look at the otaku's identity and their consumptive behaviors and practices. The critical frameworks explained in this chapter will be applied throughout this dissertation.

Additionally, other sociological theories, social psychology and identity theory, and religious history will be applied to highlight and interpret the nuances of otaku culture, as well as their role in incorporating Japanese religious tradition into popular culture. Social psychology and identity theory are useful to understand the Japanese mindset, as well as the mindset and formation of the otaku identity. Religious history helps to illustrate the role of religion in Japan, and both how religion has been shaped due to historical events and how religion itself has shaped Japanese history and culture. Other 
scholarly sources will also be used when appropriate to supplement the theories employed by this dissertation. Fandom studies and the postmodernist concerns of deconstructionism will also be noted and discussed in this analysis of the otaku to provide contemporary theory on the formation of fan groups and subsequent behaviors.

Otaku are significant as an object of critical study because their consumption of popular culture and influential role in marketing have made them a unique phenomenon. They provide a way to understand how Japanese popular culture is influencing and incorporating religious tradition. This dissertation will argue that because otaku are critically placed as an ostracized but financially powerful consumer group, they influence the incorporation of religious tradition into Japanese pop culture by using Shintō elements in their own consumption of Japanese pop culture. The influence of the otaku's subculture is one of the reasons Japanese religious ideas continue to be transmitted to newer generations through popular culture and media. Japanese media, such as anime and manga, act as a direct example of the ways Japanese popular culture reflects a continuation of and influence from practices and behaviors with regard to Japanese religion, particularly Shintō. In this chapter, the theoretical frameworks, as well as other scholarship that influenced the research for this dissertation, will be introduced and briefly discussed.

\section{MAIN THEORETICAL FRAMEWORKS}

As this is a dissertation about Japanese culture and religion, efforts have been made to provide perspectives and critical work from Japanese cultural critics and scholars. These include Toshio Okada, Eiji Ōtsuka, Hiroki Azuma, and Tamaki Saitō. Their contributions to the understanding, history, and identity of the otaku have been 
instrumental in locating the otaku within Japanese society and culture. Alongside sociologist Max Weber's thoughts on religion, capitalism, and economy, these scholars have provided a starting framework and cultural points for this dissertation.

Ōtsuka, a social critic and anthropologist, is considered an expert and scholar on otaku discourse, having been the editor involved with the first publication that printed the word "otaku" in its column. ${ }^{24}$ Okada could be considered an apologist for the otaku, an author, lecturer, and anime producer who is credited with starting "otakuology," or a study of the otaku. He is also referred to as "Otaking," or king of the otaku. ${ }^{25}$ Japanese cultural critic Hiroki Azuma has written on the otaku and their connections to pop culture through a postmodern lens. Lastly, Tamaki is a Japanese psychiatrist and critic who works with otaku and hikikomori (引きこもり), recluses. ${ }^{26} \mathrm{He}$ works attempt to depathologize the otaku and hikikomori.

\section{RELIGIOUS INFLUENCES IN SHAPING A CAPITALIST SOCIETY}

Best known as a founder of and for his contributions to sociology, Max Weber was a German sociologist who was interested in the processes of religion, rationalization, and secularization in association with the rise of capitalism. His best-known work, The Protestant Ethic and the Spirit of Capitalism, combined economic sociology and the sociology of religion, theorizing that Protestant asceticism was associated with and influential in the rise of a market-driven capitalism, as well as Protestantism's role in

\footnotetext{
${ }^{24}$ Eiji Ōtsuka, "Otaku Culture as 'Conversion Literature,"” xiii-xxix.

${ }^{25}$ See Toshio Okada, "Introduction to Otakuology," Debating Otaku in Contemporary Japan: Historical Perspectives and New Horizons, Eds. Patrick W. Galbraith, Thiam Huat Kam, and Björn-Ole Kamm, London: Bloomsbury Academic, 2015, 89-101.

${ }^{26}$ Hikikomori literally means to pull inwards, and refers to the Japanese becoming recluses. Additionally, the term otaku will be discussed further in later chapters. See Tamaki Saitō, Beautiful Fighting Girl, Trans. J. Keith Vincent and Dawn Lawson, Minneapolis: University of Minnesota Press, 2011. See also Tamaki Saitō, "Otaku Sexuality," Trans. Christopher Bolton, Robot Ghosts and Wired Dreams: Japanese Science Fiction from Origins to Anime, Eds. Christopher Bolton, Istvan Csicsery-Ronay, Jr., and Takayuki Tatsumi, Minneapolis: University of Minnesota Press, 2007, 222-249.
} 
promoting capitalism in the Western world. Weber's theories and frameworks are still being used or critiqued by contemporary scholars today. There are still regular publications of the biannual journal Max Weber Studies,${ }^{27}$ not to mention biographies of his life and work in addition to use of this theories and frameworks, such as the biography by Joachim Radkau in $2011,{ }^{28}$ Bryan S. Turner's article on sociology and resentment in $2011,{ }^{29}$ and Wolfgang Schluchter's article using Weber to analyze Western modernity in $2017 .{ }^{30}$ Clearly, there is still much to be learned from Weber's theories and life. Despite some of his theories predating and not anticipating the advent of the Internet, his frameworks still hold significant relevance for understanding the role of religion and capitalist economy in a contemporary and global world. Thus, they are particularly poignant when discussing otaku and their religious and capitalistic context.

In his The Protestant Ethic and the Spirit of Capitalism, Weber outlined his goal "to establish whether and to what extent religious influences have in fact been partially responsible for the qualitative shaping and the quantitative expansion of that 'spirit' across the world, and what concrete aspects of capitalist culture originate from them."31 Although originally published with a Western and Christian viewpoint in mind, Weber's correlation of religious "spirit" and successful capitalism is helpful when applied to modern Japanese society and religion through an examination of the otaku, as it illustrates the relationship and intersection between religion and economy in contemporary Japan. Weber's theoretical framework concerning the relationship between

${ }^{27}$ Max Weber Studies, n.d., Web, 18 Nov 2017. <http://www.maxweberstudies.org>

${ }^{28}$ Joachim Radkau, Max Weber: A Biography, Trans. Patrick Camiller, Cambridge: Polity, 2011.

${ }^{29}$ Bryan S. Turner, "Max Weber and the Spirit of Resentment: The Nietzsche Legacy," Journal of Classical Sociology 11.1 (2011): 75-92.

${ }^{30}$ Wolfgang Schluchter, "Dialectics of Disenchantment: A Weberian Look at Western Modernity," Max

Weber Studies 17.1 (2017): 24-47.

${ }^{31}$ Max Weber, The Protestant Ethic, 36. 
religion and economy is well-suited for discussing the otaku and highlighting the dynamics of their role in religion and economy in contemporary Japanese society because it is reflected in their consumption of pop products coupled with incorporated religious elements. Indeed, the influence of the otaku's subculture is one of the reasons Japanese religious ideas continue to be transmitted to newer generations through popular culture and media.

\section{PURSUIT OF THE CALLING IN COMMODIFYING JAPANESE CULTURE}

One major otaku influence on the whole of Japanese society is the creation of anime and manga. There are various aesthetic styles, detailed story and plotlines, and personality characteristics influenced by the otaku's connoisseurship of anime and manga. Creators of manga and anime could almost be considered to be pursuing a "calling" in the Weberian sense, especially when one considers the fact that anime and manga artists make little money. ${ }^{32}$ With regard to one pursuing their calling, Weber states "that one's duty consists in pursuing one's calling [Berufspflicht], and that the individual should have a commitment to his "professional' [beruflichen] activity." ${ }^{, 33}$ All individuals, from the farmer to the wealthiest aristocrat, should work or pursue an activity that is productive. In other words, it is the individual's duty and purpose to pursue their calling through labor, as it is a blessing from God. The anime and manga artists pursue their calling in the form of a craft, which in turn is shaped by the otaku who consume the works produced. The otaku themselves are pursuing a calling, although it may not be considered productive as the calling Weber was referring to, by purchasing and consuming the goods created by these artists. As Okada points out, it is not the artist who

\footnotetext{
${ }^{32}$ See “Animators' Harsh Work Conditions," Biz/Tech, NHK World, 27 Apr 2015, Web, 24 Feb 2016. $<$ http://www3.nhk.or.jp/nhkworld/english/news/20150428_20.html>

${ }^{33}$ Max Weber, The Protestant Ethic, 13.
} 
is important in the production of popular products but the otaku who consume them.

Okada argues that the otaku are the legitimate heirs to Japanese culture and that in Japan, "the receiver who 'understands the beauty of a work and can put this understanding into words' has a higher status in Japanese culture" than people whom merely consume the work. ${ }^{34}$ This idea is in stark contrast to the mainstream treatment of otaku, namely that they are shunned and often criticized. However, the "otaku subculture" is often commodified by mainstream Japan to promote products to the masses, as will be discussed. The otaku and artist/creators pursue their callings in the social conduct of capitalist Japan and, hence, influence the transmission and commodification of Japanese culture. This framework is necessary to understanding the influence that the otaku have within society, despite their position, and that their influence where religion and popular culture are concerned require closer examination.

\section{CREATION OF SPECIALIST GROUPS IN CAPITALIST ECONOMY}

This relationship between the otaku and the creators of the media they consume is a result of capitalist economic life in Japan. This relationship is unlike anything found in pre-capitalist Japan, where art and associated products were not churned out based on consumer demand, solely for profit. In regards to a Western capitalist society, Weber pointed out that capitalism created the entrepreneurs and workers that were needed. He understood that capitalism dominated economic life, creating an "economic selection" of its subjects, the entrepreneurs, and workers that are needed to sustain it. Weber argues that the workers and entrepreneurs did not just originate solely due to a capitalist economy, but that they were already formed by groups of people, possibly workers or

\footnotetext{
${ }^{34}$ Toshio Okada, "Introduction to Otakuology," Debating Otaku in Contemporary Japan: Historical Perspectives and New Horizons, Eds. Patrick W. Galbraith, Thiam Huat Kam, and Björn-Ole Kamm, London: Bloomsbury Academic, 2015, 97.
} 
artisans. He states that in "order that this kind of conduct of life and attitude to one's 'profession' ['Berufs'-Auffassung], 'adapted' as it is to the peculiar requirements of capitalism, could be 'selected' and emerge victorious over others, it obviously had first come into being, and not just in individuals, but as an attitude held in common by groups of people." 35 Thus, these groups and roles existed before being officially formulated as callings. In the context of pre-capitalist Japan, this means that people followed their calling to fulfill a societal or artistic role rather than for monetary gain.

In Japan, individuals will normatively identify themselves with a group comprised of their coworkers or colleagues who are in a similar profession. But artistic creators and otaku were created and trained by capitalism in their creation and consumption of pop products. Ōtsuka claims that the first generation of otaku, born in the 1960s, refused to let go of anime and manga as children's culture, and subsequently began to work in media which founded a new market they created and participated in. ${ }^{36}$ It is a symbiotic relationship fed by the need to make money on the part of the artistic creators and the companies they work for, and to consume pop products associated with their favorite series or characters on the part of the otaku. This niche market also spills over into the mainstream, as these products are often widely sold across Japan or online and are available to anyone who wishes to purchase them. This spillover is especially relevant, as it acts as the vehicle through which otaku exercise their power over religious influence within popular culture. Without the creation of these roles, the respective artist and otaku specialist groups, this dynamic may not exist.

\footnotetext{
${ }^{35}$ Max Weber, The Protestant Ethic, 16-17.

${ }^{36}$ Eiji Ōtsuka, "Otaku Culture as 'Conversion Literature,"” xix.
} 


\section{ASCETICISM}

Additionally, while Weber examines the role and influences of Protestantism, (starting with Martin Luther) on capitalism and economy in the West,${ }^{37}$ his ideas are useful in examining the impact and the social position of the otaku in Japan. Though they share similarities, the Protestants and otaku also have meaningful differences that point to a unique phenomenon within Japan and its own relationship between religion and economy. As Protestantism grew, it moved away from the traditional asceticism found in Catholic monasticism. Weber claims that the goal of asceticism is for the individual to lead a watchful, aware, and alert life that did not engage solely in "instinctive pleasure," or pleasures that did nothing to glorify God. ${ }^{38}$ The otaku also appear to practice a form of asceticism. Rather than rejecting entertainment and "instinctive pleasures," as Protestantism encouraged, the otaku engage in entertainment as it relates to their identity as otaku.

Entertainment and related products appear to make up a large portion of the otaku's identity and consumptive behaviors. For Weber, the "most important means employed by asceticism was to bring order into the conduct of life of those who practiced it. ${ }^{\prime 39}$ Though this definition of asceticism is in reference to Christians in the West, historically the Japanese also practiced similar forms of asceticism, regulated by Buddhism, with the intent of living an aware and alert life. But in a contemporary world not everyone is able to adhere to such a life, sequestered away in a monastery-not everyone could be an ascetic in pre-modern Japan, either. In contemporary Japan it is

\footnotetext{
${ }^{37}$ See Max Weber, The Protestant Ethic and the Spirit of Capitalism, Trans. Peter Baehr and Gordon C. Wells, New York: Penguin Books, 2002.

${ }^{38}$ Max Weber, The Protestant Ethic, 81.

${ }^{39}$ Max Weber, The Protestant Ethic, 81.
} 
especially hard considering the role of technology and communication in most people's lives. In a capitalist world, being an ascetic is nearly impossible, as one needs to work to live. Monks worked, but did not earn money to purchase the necessities of a modern day worker. The otaku, however, are mostly solitary, although not entirely reclusive, and are willing to spend their money on products associated with their interests, especially where anime and manga are concerned. These products are often consumed in private but they can be purchased in a communal setting, such as a convention where other otaku have gathered, or specialty shops such as those found in Akihabara, Tokyo, Japan.

Furthermore, Weber's thoughts on the Puritans provide a meaningful contrast to the otaku. The otaku live in a colorful and vibrant world, but they focus solely on their interests and hobbies (in this case, manga and anime). Touching back on the ideas of monasticism mentioned earlier and the role of the Puritans, Weber claims "when asceticism moved out of the monastic cells and into working life, and began to dominate innerworldly morality, it helped to build that mighty cosmos of the modern economic order." ${ }^{40}$ According to Weber, if the Puritan "will only persevere on the ascetic path, then the more possessions he acquires, the heavier becomes the feeling of responsibility to preserve them undiminished to God's glory and to increase them through tireless labor.." ${ }^{41}$ Money and possessions were something tangible and served as a means with which to see the proximity of their salvation. For the Protestant in general, "asceticism works with all its force against the uninhibited enjoyment of possessions; it discourages consumption, especially the consumption of luxuries. ${ }^{42}$ In contrast, the otaku do not discourage consumption. Although they enjoy their possessions, which can be considered

\footnotetext{
${ }^{40}$ Max Weber, The Protestant Ethic, 120.

${ }^{41}$ Max Weber, The Protestant Ethic, 115.

${ }^{42}$ Max Weber, The Protestant Ethic, 115.
} 
luxuries, they serve no utilitarian purpose, and they actively consume these products, possibly in an attempt to be closer to as well as foster a relationship with the fictional character they fetishize. The otaku practice this worldly asceticism by existing and indulging in the everyday world, through their consumption of popular culture, as a means to be closer to their beloved fictional characters. Instead of focusing on salvation, they are concerned with present or future moments with these animated female characters.

The otaku spend money freely on products associated with their pop culture figures. When it comes to themselves, they are thrifty where necessities are concerned, like clothing or food. In contemporary Japan, the otaku are described as not caring about fashion and being unkempt looking, as columnist Akio Nakamori pointed out in his 1983 column “' 'Otaku’ no Kenkyü” [“'Otaku' Research”]. This column has been criticized due to its unflattering portrayal of the otaku, especially by Manga Burikko's editor Ōtsuka, for Nakamori's description of the otaku as, "smartly clad in shirts and slacks their mommy bought at the 'all $¥ 980 / 1980$ rack ... their feet shod in ' $\mathrm{R}$ ’-branded knock-offs of Regal sneakers that were popular several years ago, shoulder bags bulging and sagging. "43 Some otaku responded to the column by the next issue, with some agreeing with Nakamori's description. Thus, it can be inferred that the otaku prefer to live a plain lifestyle. The otaku amass their money like the Puritans, but they focus on the collection of items rather than fetishizing money itself. These spending habits and practices will be elaborated on further in Chapter Four.

\footnotetext{
${ }^{43}$ Quoted in Yamanaka Tomomi, "Birth of 'Otaku': Centring on Discourse Dynamics in Manga Burikko," Debating Otaku in Contemporary Japan: Historical Perspectives and New Horizons, Eds. Patrick W. Galbraith, Thiam Huat Kam, and Björn-Ole Kamm, London: Bloomsbury Academic, 2015, 36.
} 


\section{WEBER AND CHARISMA}

Inasmuch as Weber's theoretical framework will be applied overall to this dissertation, his theories on charisma are also beneficial to this analysis. When applied to the otaku and the creators of the pop media they consume, one can better understand the influence that both have on the influencing and commodifying of Japanese religious traditions and culture. The otaku themselves possess a charisma that influences the media they consume which subsequently allows for an examination of the intersections of religion and pop culture, as will be seen through the otaku's behaviors and practices in Chapter Four. According to Weber, charisma is a quality of leadership. There have been leaders who have possessed charisma, which has allowed them to retain power and to preserve their institutions after death, typically through the routinization of their charisma on the part of their charismatic leaders' administrative staff. ${ }^{44}$ For instance, religious figures such as the Buddha and Jesus are two charismatic leaders whose thoughts and ideals became routinized and established as organized religions. In this regard, Weber claims, "the routinization of charisma also takes the form of the appropriation of powers of control and of economic advantages by the followers or disciples, and of regulation of the recruitment of these groups. ${ }^{, 45}$ A significant feature of the charismatic figure is that they exist outside of accepted societal norms. Usually, such a figure rejects or operates outside that which is considered "normative," and does so in a manner that does not remove them entirely from their followers and eventual economic advantages. Weber states, "In order to do justice to their mission, the holders of charisma, the master as well as his disciples and followers, must stand outside the ties of this world, outside of routine

\footnotetext{
${ }^{44}$ Max Weber, Max Weber on Charisma and Institution Building, Ed. S.N. Eisenstadt, Chicago: University of Chicago Press, 1968, 57.

${ }^{45}$ Max Weber, Max Weber on Charisma and Institution Building, 58.
} 
occupations, as well as outside the routine obligations of family life." ${ }^{, 46}$ The nature of charisma fluctuates in the study of the socio-religious phenomena surrounding the otaku, as well as the study of Japanese popular culture and religion.

Differing levels and qualities of charisma affect and are possessed by the creators or artists, the otaku themselves, and the pop culture figure who are the objects of otaku devotion. "Pop culture figure" is meant to be an umbrella term and refers to the otaku's object of reverence or desire. For now, the term "figure" will be used to refer to fictional anime and manga characters, human voice actresses, and pop singers. These figures have some similarities to kami, or deities and spirits, and some otaku practices appear to be incorporating Shintō elements in their consumption of media featuring them. As will be seen, much of Japanese culture and pop culture is under the pervading influences of Japan's indigenous religion, Shintō, and there appears to be certain reverence paid to these figures from popular culture and media.

While the pop culture figure can be artificially created, her charisma is, on one level, dependent upon that of her creator. Charisma fluctuates in several ways. First, the creator or artist of a popular series will possess enough charisma to present a female popular character to otaku who then actively follow her through the creator's social media and works. Second, the otaku then possess a level of charisma in their unwitting position as a resource for the government to promote tourism through its Cool Japan programs. ${ }^{47}$ Arguably, the otaku's charisma is routinized as an institution of sorts through

\footnotetext{
${ }^{46}$ Max Weber, Max Weber on Charisma and Institution Building, 21.

${ }^{47}$ Cool Japan is a concept that was coined in 2002 and is in reference to Japan's growth as a cultural superpower. The Japanese government promotes Cool Japan as a brand to encourage tourism, as well as to exploit the potential commercial capital of Japan's culture industry. This concept will be discussed further in Chapter Three. See Christine R. Yano, "Wink on Pink: Interpreting Japanese Cute as It Grabs Global Headlines," The Journal of Asian Studies 68.3 (2009): 683 and Nagata Kazuaki, "Exporting Culture Via 'Cool Japan,"' The Japan Times 15 May 2012: 3.
} 
the efforts of "Cool Japan." Big name companies like automobile makers Toyota and Subaru have also tapped into this aspect of pop culture to market its products. For instance, in 2011 Toyota paired up with virtual idol and Vocaloid, Hatsune Miku for several commercials for the Toyota Corolla. ${ }^{48}$ Subaru featured figures from the anime and manga, Shingeki no Kyojin [Attack on Titan], in their 2014 commercial for the Subaru Forester. ${ }^{49}$

Additionally, the otaku has an influence on pop culture products. Many products feature popular characters from anime and manga, and are often used for promotions. Pizza Hut used Shingeki no Kyojin for various promotions. Pizza Hut has been featured in anime series or in promotions coupled with a popular anime series, such as Love Live!. ${ }^{50}$ The Japanese convenience store chain Lawson features regular promotional items and products featuring characters from various anime and manga, such as The Idolmaster. ${ }^{51}$ The otaku are instrumental in marketing what are presented as desirable products, which are initially marketed specifically for the otaku, and also made available to the mainstream public. Third, the pop culture figure itself possesses a degree of charisma in that the figure itself begins to possess a social and cultural life of its own. For instance, the character is talked about as if it is alive and whether certain actions are out-ofcharacter for her when otaku criticize an episode of the series or a fan work. The figure can also make certain name-brand products popular because she uses them, and so on.

When the pop culture figure possesses its own level of charisma, the otaku will purchase nearly any item that bears her resemblance. So long as her charisma is

\footnotetext{
${ }^{48}$ See Appendix A Figure 1.1.

${ }^{49}$ See Appendix A Figure 1.2.

${ }^{50}$ See Appendix A Figure 1.3.

${ }^{51}$ See Appendix A Figure 1.4.
} 
recognized, she remains an object of desire and reverence. Those who hold charisma cannot permanently hold it or possess it; indeed, they can lose their charisma at any time. If they are not meeting the expectations of the devotees, then the leader and items associated with the leader are destroyed or forgotten. All charismatic influence once held over the devotees is lost and they move on to another who possesses charisma. Weber explains:

\begin{abstract}
"Charisma knows only inner determination and inner restraint. The holder of charisma seizes the task that is adequate for him and demands obedience and a following by virtue of his mission. His success determines whether he finds them. His charismatic claim breaks down if his mission is not recognized by those to whom he feels he has been sent. If they recognize him, he is their master - so long as he knows how to maintain recognition through 'proving' himself. But he does not derive his 'right' from their will, in the manner of an election. Rather, the reverse holds: it is the duty of those to whom he addresses his mission to recognize him as their charismatically qualified leader." 52
\end{abstract}

The creators' mission is producing these characters and meeting the expected standards of aesthetic and artistic qualities. The otaku's mission is to consume and influence what is considered a desirable product. Clearly, this is a reciprocal relationship between creators or artists and the otaku. Subsequently, the creators and artists lose power when they fail to prove or appease the otaku in terms of aesthetic quality and artistry. Similarly, the pop culture figure loses power if she does not prove her virginal virtue or dedication to the otaku whose gaze she commands. Many series involve hypersexualization of these virginal figures, but the idea is that the character is pure and her virginity is an imagined one that is reserved for just the otaku. Should the pop culture figure have a boyfriend or be proven to have engaged in sexual acts (i.e. losing her virginity), she is immediately

\footnotetext{
${ }^{52}$ Max Weber, Max Weber on Charisma and Institution Building, 20.
} 
deemed undesirable and objects bearing her image may be destroyed. ${ }^{53}$ If they lose their power, the products that are associated with the creators are destroyed and/or no longer purchased. In this case, charisma plays an economic role, as it is the pop culture figures with charisma that influences the products bought. The otaku's consumption of these products appears to incorporate religious elements, and these products as well as their consumption by the otaku will be closely examined and discussed further in Chapter Four.

\section{SOCIAL CONSTRUCTION OF RELIGIOUS EXPERIENCE}

Peter L. Berger argues that social realities are constructed and that mankind continually legitimates reality with each new generation. ${ }^{54}$ On two levels, the objective and subjective, humans maintain their own understanding and construction of realityreality maintenance. ${ }^{55}$ Each generation shapes reality according to differing individual experiences and thoughts. Berger explains, "The reality of the world as socially defined must be maintained externally, in the conversation of men with each other, as well as internally, in the way by which the individual apprehends the world within his own consciousness." ${ }^{, 56}$ Berger contends that religion helps shape this construction and understanding of reality. One such construct relates to the way that religion validates the division of sacred and profane, two separate divisions of reality distinct from one another. Berger argues:

\footnotetext{
${ }^{53}$ There will be a detailed example in Chapter Four concerning Love Live! For this instance, another example will be provided. An otaku who liked the 2006 series Kannagi was upset when he found out the main character, Nagi, had an ex-boyfriend. He proceeded to destroy his manga and DVDs, as well as the figurines of Nagi. This otaku posted the images on 2channel for other otaku to see.

${ }^{54}$ Berger's work has an underlying reliance on Emile Durkheim's notion of religious society, as well as Mircea Eliade's notions of the sacred and the profane. Peter L. Berger, The Sacred Canopy: Elements of a Sociological Theory of Religion, Garden City: Anchor Books, 1967, 30.

${ }_{55}^{55}$ Peter L. Berger, The Sacred Canopy, 3-7, 17.

${ }^{56}$ Peter L. Berger, The Sacred Canopy, 32.
} 
"Religion legitimates social institutions by bestowing upon them an ultimately valid ontological status, that is, by locating them within a sacred and cosmic frame of reference. The historical constructions of human activity are viewed from a vantage point that, in its own selfdefinition, transcends both history and man." 57

Berger's theories share similarities to Mircea Eliade's thoughts concerning the sacred and the profane, especially with regard to the construction of sacred space and profane space.

Eliade's theoretical frameworks of sacred and profane are of great use to this dissertation. For instance, Eliade's theory of the identity and use of sacred space, as well as his thoughts on human experience and existence, help to highlight the otaku's demarcation of sacred and profane space in their own behaviors and practices. ${ }^{58}$ Similarly, Peter Berger's theories have also provided a basis for the structure of religion and society in this dissertation. Berger's The Sacred Canopy and The Social Construction of Reality examines the construction of reality, at both macrocosmic and microcosmic levels, ${ }^{59}$ not to mention the role of religion in constructing one's reality.

The construction of reality also depends on the interactions shared between individuals. When humans interact with one another, they try to fit one another into a category to better determine how to interact with them. Berger and Luckmann claim that in interactions with another person, one typifies and is typified; "the two typificatory schemes enter into an ongoing 'negotiation' [...] likely to be arranged in a typical manner. ${ }^{\circ 60}$ Participants in interpersonal interactions place a person they are speaking with into a type to better understand, relate, and communicate with them. This relates directly

\footnotetext{
${ }^{57}$ Peter L. Berger, The Sacred Canopy: Elements of a Sociological Theory of Religion, Garden City: Anchor Books, 1967, 33-34.

${ }^{58}$ This will be discussed and examined further in Chapter Four.

${ }^{59}$ Peter L. Berger, The Sacred Canopy, 34-39.

${ }^{60}$ Peter L. Berger and Thomas Luckmann, The Social Construction of Reality: A Treatise in the Sociology of Knowledge, Garden City: Doubleday, 1966, 31.
} 
to the otaku, as they are often typified by non-otaku. One common stereotype and claim concerning otaku is that they are unable to interact socially. Berger's theory explains this claim as being due to the elusive identity of the otaku. They are not easily typified by the non-otaku who engages the otaku in social interactions. Namely, one may not always identify themselves as an otaku due to the negative connotations associated with the otaku.

As has been noted, Mircea Eliade's work is also beneficial to this dissertation, as he examines sacred space, sacred time, sacrality of nature, and sanctified life, and demonstrates the ways in which humans sacralize their existence. Apart from his conceptions of the sacred and profane, Eliade's concept of "homo religiosus" is easily applicable to otaku. Religious man, as Eliade explains, "lives in a sacred world, or desires to, because it's the only one in which Religious man has real existence.",61 Otaku are more comfortable living in an online or fantasy world populated by their desired pop culture characters. These online spaces are where the otaku has an accepted existence that is not criticized or invalidated by others. The use of these theories, when applied to otaku and the growth of electronic communication and communities through technology, strengthens the concept that the otaku are part of a phenomenon that displays religiouslike cult tendencies, where 'cult' refers to the deviation from traditional Shintō rituals and practices, as will be evidenced in Chapter Four.

The theoretical frameworks beneficial to this dissertation examine the roles of religion in economy and construction of society and space. However, insofar as these frameworks are useful for this dissertation, it should be noted that they do have some

\footnotetext{
${ }^{61}$ Mircea Eliade, The Sacred and the Profane: The Nature of Religion, Trans. Willard R. Trask, Orlando: Harcourt Brace Jovanovich, 1987, 64.
} 
limitations due to being written before the Internet was widely available to the public and before globalization through technology. In 1966, Berger claimed, "it is impossible for man in isolation to produce a human environment. ${ }^{362}$ Although this may have been true at the time that Berger was writing, human environments today are being created in global online communities. Thus, the otaku are able produce virtual realities while they isolate themselves from physical reality.

In isolation, the otaku can establish an ongoing relationship with the online space they occupy in addition to the real world. Berger's other work, The Sacred Canopy, argues that humans must establish an ongoing relationship with the world because unlike animals, humans are not born into a species-specific world. ${ }^{63} \mathrm{He}$ argues that humans are social and prefer to live in a structured space, which Berger calls a nomos, ${ }^{64}$ and that separating humans from a social world constitutes a threat to the individual. ${ }^{65}$ Another limitation to Berger is his belief that isolating humans from physical social interaction was a threat, which is no longer relevant to a modern society that is largely connected through online and technological communication. People today communicate through various electronic mediums, and otaku, as well as nearly everyone else, replace physical proximity with electronic proximity. The otaku are able to remain connected and have social interaction due to the increasing use of electronic networks and technology. They are able to formulate communities electronically and construct new realities centered around their primary interests.

\footnotetext{
${ }^{62}$ Peter L. Berger and Thomas Luckmann, The Social Construction of Reality, 51.

${ }^{63}$ Peter L. Berger, The Sacred Canopy, 5.

${ }^{64}$ Nomos refers to order, such as a structured space.

${ }^{65}$ Peter L. Berger, The Sacred Canopy, 21.
} 


\section{SOCIAL PSYCHOLOGY AND IDENTITY THEORY}

To better understand how the Japanese function within their society, and how the otaku constructs his identity, it is beneficial to examine the Japanese and otaku through a psychological lens. Works in the field of psychology, especially social psychology, are useful as they provide a background for understanding self-categorization and social identity, which is at play in the life of an otaku. Japan is considered a collectivist society and "social identity processes are fundamental to understanding collective behavior." 66 Most Japanese are part of an ingroup and the otaku are no exception. In school they will join clubs that relate to their interests and ingroup. One's social identity is typically arranged according to their social groups, shifting from group to group. Social psychologist John C. Turner states, “'Social identity’ was conceptualized as that aspect of a person's self-concept based on their group memberships" and that people will define themselves in terms of some social group membership. ${ }^{67}$ Identity formation theory and social psychology also provide a basis for understanding what is considered normative Japanese behavior in opposition to "otaku" behavior. By knowing how group social identity and self-categorization occur, this research can locate the otaku's unique positions within, not only the typical Japanese populace, but within typical Japanese fandom as well, such as アイドル [aidoru], translated as “pop idol,” fans, baseball fans, sumo fans, and many other non-anime and non-manga related fandoms. ${ }^{68}$

\footnotetext{
${ }^{66}$ John C. Turner, "Some Current Issues in Research on Social Identity and Self-Categorization Theories," Social Identity: Context, Commitment, Content, Eds. Naomi Ellemers, Russell Spears, and Bertjan Doosje, Oxford: Blackwell, 1999, 6-7.

${ }^{67}$ John C. Turner, "Some Current Issues in Research on Social Identity and Self-Categorization Theories," 8.

${ }^{68}$ See Fanning the Flames: Fans and Consumer Culture in Contemporary Japan, Ed. William W. Kelly, Albany: State University of New York Press, 2004.
} 


\section{RELIGION, PRACTICES, AND PILGRIMAGE}

Joseph M. Kitagawa is useful to the understanding of the religious Japanese

mindset and pilgrimage.$^{69}$ Equally important to understanding the role of pilgrimage will be the work of Victor and Edith Turner, ${ }^{70}$ as will be seen in the discussion of pilgrimage in Chapter Four. Kitagawa's presentation and analysis of Japanese religions provides a solid historical background for understanding the function and development of religion within Japan. His work helps to situate and frame the otaku's behaviors and practices in the context of Japanese religious history and culture as a whole. As Shintō and other Japanese religious practices accommodated modernity, the otaku influence Shintō shrines and incorporate Shintō elements into their behaviors and practices. Again, it should be noted that the otaku hold a paradoxical relationship within Japanese society, as they are held with contempt by the mainstream but also regarded as purveyors of popular media to help promote the Cool Japan brand.

Travel, especially the concept of "pilgrimage," appears to be a common theme found in certain Cool Japan programs, such as those offered by online travel sites, like Trip Advisor. This stems from a particular facet of otaku practice, their "pilgrimages," which have roots in traditional Shintō and Buddhist pilgrimages. During these pilgrimages, otaku visit Shintō shrines that they associate with, or that were featured, in a specific anime or manga. As with typical pilgrimages, such as those found associated with the Abrahamic traditions, pilgrims travel to sites that are regarded to be holy, where

\footnotetext{
${ }^{69}$ See Joseph M. Kitagawa, "Three Types of Pilgrimages in Japan," Experience of the Sacred: Readings in the Phenomenology of Religion. Eds. Sumner B. Twiss and Walter H. Cosner, Hanover: University Press of New England, 1992, 177-187. See also Joseph M. Kitagawa, Religion in Japanese History, New York: Columbia University Press, 1990.

${ }^{70}$ Victor and Edith Turner, Image and Pilgrimage in Christian Culture: Anthropological Perspectives, New York: Columbia University Press, 1978.
} 
miracles have happened or as a site of historical religious significance. Undertaking a pilgrimage in Japan is similar, but under Buddhist influences pilgrims gain merit for their salvation (i.e. Nirvana) and very often to gain good fortune or other benefits associated with that particular pilgrimage site. Kitagawa describes Japanese pilgrimages in the following passage:

"traveling a long distance, visiting holy mountains or shrines, involves physical hardship and endurance, but it also has pleasurable aspects, such as sightseeing and meeting new friends. Usually pilgrims are motivated by religious objectives, such as adoration of the deities or saints who are enshrined at various sacred places, gaining merit for one's salvation, paying penance for annulment of sin, or praying for the repose of the spirits of the deceased, but these motives are often mixed with the desire to acquire healing, good fortune, easy childbirth, prosperity and other this-worldly benefits." ${ }^{, 71}$

The otaku perform pilgrimages in a similar manner. Many times, the otaku will visit a Shintō shrine or similar location if it served as the setting or as a location that their favorite female anime or manga character visited. During their visit there, they can purchase a number of amulets, talismans, and other objects that provide them a thisworldly benefit. There is also the idea that by visiting these locations, they able to express their adoration or be close to their pop culture figure who was depicted in the location that becomes a "pilgrimage" site for the otaku. There is also a social dimension, as some otaku will travel with a small number of companions and may perform cosplay ${ }^{72}$ during

\footnotetext{
${ }^{71}$ Joseph M. Kitagawa, "Three Types of Pilgrimages in Japan," Experience of the Sacred: Readings in the Phenomenology of Religion, Eds. Sumner B. Twiss and Walter H. Cosner, Hanover: University Press of New England, 1992, 178-179.

${ }^{72}$ Cosplay is short for "costume play," which is the act of dressing up as one's favorite character from an anime, manga, videogame, etc. Typically, cosplay is performed within fan spaces, such as conventions. However, some otaku and fans will perform cosplay outside of fan spaces, such as the otaku who cosplay at shrines.
} 
their visits to the pilgrimage sites. ${ }^{73}$ During visits to these places, the otaku typically purchase a special item that they customize with images of their beloved pop culture figure.

These special items offered for sale in Shintō shrines in Japan are called ema, which are wooden prayer tablets. ${ }^{74}$ The ema are different from the amulets and talismans that can also can be purchased at shrines. Ema serve as messages to the kami and visitors can read them or offer prayers on behalf of the petitioner. ${ }^{75}$ The visitor may write a wish or a prayer request on these tablets, along with their name. ${ }^{76}$ Otaku inscribe the tablets with drawings of their favorite fictional female characters, the pop culture figure, and will write their desire for these characters to be their wife, to wish them happy birthday, and so on. Further discussion of these behaviors and practices will be discussed in Chapter Four.

Kitagawa's historical analysis of Japanese religions traditions proves valuable when tracing the role of Shintō in the lives of the Japanese. He points out that the earliest forms of Shintō were also taken for granted, much like the otaku and Shintō today. Kitagawa claims that many Japanese "took for granted that they were integrally part of the cosmos, which they saw as a 'community of living beings,' all sharing the kami (sacred) nature." 77 What this means is that the otaku, like many Japanese, are not cognizant or constantly dwelling on the kami at all times. Nature is imbued with the kami and everything is living and connected, which is of value, but nature and the kami are not

\footnotetext{
${ }^{73}$ See Appendix A Figure 1.5.

${ }^{74}$ Ema translates to "horse picture." The previous year's ema are gathered and burnt during the first week of New Year's at the shrine. See Appendix A Figure 1.6.

${ }^{75}$ Brian Bocking, A Popular Dictionary of Shintō, Surrey: Curzon Press, 1996, 26.

${ }^{76}$ See the entry on ema in Brian Bocking, A Popular Dictionary of Shintō, Surrey: Curzon Press, 1996, 2526.

${ }^{77}$ Joseph M. Kitagawa, Religion in Japanese History, New York: Columbia University Press, 1990, 12.
} 
the main focus of one's life. Technology and pop culture are respected and revered by the otaku, but they are not always aware of the similarities between their consumptive habits and practices to Shintō practices, as will be examined in Chapter Four. Rather than focusing on their ties to nature, such as trees and rivers, the otaku are closely connected through pop culture media and technology. There appears to be some similarities or links between the kami and the fictional characters in the otaku's favorite anime or manga series.

\section{OTHER POINTS OF DISCUSSION}

In addition to the theoretical frameworks and theories being used to inform this dissertation, some other theories are also of note. For instance, Emile Durkheim's thoughts on the formation of religious communities and social knowledge are beneficial. Durkheim's thoughts may be considered dated, but are useful in analyzing the religious nature of otaku, especially his theories from The Elementary Forms of Religious Life. ${ }^{78}$ Durkheim understands and links religious experience as part of a social nature and claims that "religion has not merely enriched a human intellect already formed but in fact has helped form it."79 The otaku grow up with Shintō and Buddhist practices and elements that are deeply rooted in their culture. Durkheim's work links religion with society, defining religion as a system of beliefs and as a system of ideas in which individuals imagine the society of which they are members and obscure but intimate relations they have with it. ${ }^{80}$ Therefore, it can be argued that otaku learn their knowledge and beliefs from society at large, including traditional beliefs in Shintō, and continue learning and evolving their beliefs by way of their own otaku communities, most of which interact and

\footnotetext{
${ }^{78}$ Emile Durkheim, The Elementary Forms of Religious Life, New York: Free Press, 1995.

${ }^{79}$ Emile Durkheim, The Elementary Forms of Religious Life, 2, 8.

${ }^{80}$ Emile Durkheim, The Elementary Forms of Religious Life, 44, 227.
} 
engage in dialogue in online communities. There is also the idea that practice equals devotion, and the otaku are certainly devoted to their pop culture figures.

Deconstructionism is another theory beneficial to understanding the socioreligious phenomenon of the otaku, as this dissertation is attempting to reevaluate the role of religion and popular culture in society. The way that this is being deconstructed is through the examination of consumption by the most influential consumers, the otaku, who appear to be incorporating and influencing religious tradition through popular culture. With regard to deconstructing this phenomenon, Daniel Miller's $A$ Theory of Shopping was also influential in his framework and study of the act of shopping. ${ }^{81}$ Miller argued that shopping itself could be construed as a religious act for the family, in which the shopper sacrifices and denies their own desires. His work examines the gap between discourse and practice, the relationship between shopping and sacrifice, and he concludes, "a parallel is drawn between shopping and sacrifice in that both are found to be practices whose primary goal is the creation of a desiring subject." ${ }^{\prime 82}$ According to Miller, the act of shopping itself is transcendent as it creates ideal relationships.

Even though Miller is focused on the family unit, his work provides a good starting point for comparing and understanding how the otaku's purchasing of pop products is rooted solely in the desires of the otaku themselves. Miller points out that one typically buys things for others based on their relationship to those people and vice versa; "your shopping is dominated by your imagination of others, what they desire of you and their response to you; it is about relationships to those who require something of you." ${ }^{\prime 83}$ The otaku are not buying pop products for others, but for themselves, and to an extent, to

${ }^{81}$ Daniel Miller, A Theory of Shopping, New York: Cornell University Press, 1998.

${ }^{82}$ Daniel Miller, $A$ Theory of Shopping, 8.

${ }^{83}$ Daniel Miller, $A$ Theory of Shopping, 3. 
support the creators of their favorite works so that those works and the otaku's relationship with the pop culture figure can continue, it is a devotional-like act. Miller explains that the "presence of gods is made manifest by the sense that they desire or demand sacrifice," and the otaku's acts of shopping and consumption are similar. ${ }^{84}$ The pop culture figure is made manifest by the idea that these figures demand the otaku sacrifice their money and devotion. The otaku's act of shopping is dominated by their imagination and relationship to the pop culture figure or the creators and artists of their favorite series. The otaku buy products associated with their pop culture figure in an effort to please or strengthen the otaku's bond to his object of devotion. Their practices and behaviors are similar to the devotional rites that were meant to create desiring subjects, such as those found in Miller's study. ${ }^{85}$

The otaku's purchasing of pop products associated with their pop culture figure and works produced by artists/creators that they faithfully follow is itself an act of devotion, although the product is being purchased for the otaku themselves. This act of purchasing pop products is not entirely unlike the shopper's purchasing of groceries other consumer goods. Rather, it is the otaku's act of shopping that is more personal and aimed at the individual instead of their family or a community of non-otaku. Instead of sacrificing themselves for their families, the otaku self-sacrifice themselves for their desiring subjects, the pop culture figure or the creator/artist that they are devoted to.

In addition to using Miller to consider the spending habits and deconstruction of otaku behaviors and identity, another work that will used to provide insight into Japanese fan behaviors is Fanning the Flames: Fans and Consumer Culture in Contemporary

\footnotetext{
${ }^{84}$ Daniel Miller, A Theory of Shopping, 8.

${ }^{85}$ Daniel Miller, $A$ Theory of Shopping, 20.
} 
Japan edited by William W. Kelly. ${ }^{86}$ This text provides an anthropological examination of fandom in Japan, an overview of the basic understanding and structuring of "typical" fandom in Japan, and examining the types of fandom that currently exist in contemporary Japan. ${ }^{87}$ The essays focus on several types of fandom, such as sumo and baseball fans, in Japan and how Japanese fans "creatively rework their selections into a stylized matrix of practices and identities" as well as "consume mass culture, but in their voracious and determined consumption, they produce both social communities and cultural artifacts. ${ }^{\prime 88}$ This work also raises the issue of whether most Japanese are inclined to be fans due to a national characteristic and points out that "there may well be certain historical and contemporary features of social practices in Japan that give impetus and form to certain fan patterns. ${ }^{, 89}$ This in itself is an important speculation for this dissertation's thesis that Japanese popular culture reflects a continuation and highlights an influence from Japanese religion with regard to otaku practices and behaviors, while exploring what is particular to Japan due its associations with Shintō.

\section{CONCLUSION}

There are numerous methods of examining fan consumption, fan behaviors, connections of religion to popular culture, and the influence of religious traditions. Nevertheless, there are not many theories that deal directly with the ways in which Japanese popular culture is influencing and incorporating Japanese religious traditions through the otaku, the largest consumers of Japanese pop culture. The goal of this

\footnotetext{
${ }^{86}$ Fanning the Flames: Fans and Consumer Culture in Contemporary Japan, Ed. William W. Kelly, Albany: State University of New York Press, 2004.

${ }^{87}$ William W. Kelly, "Introduction: Locating the Fans," Fanning the Flames: Fans and Consumer Culture in Contemporary Japan, Ed. William W. Kelly, Albany: State University of New York Press, 2004, 1-16.

${ }^{88}$ William W. Kelly, "Introduction: Locating the Fans," 1-2.

${ }^{89}$ William W. Kelly, "Introduction: Locating the Fans," 11.
} 
dissertation is to illustrate how these otaku behaviors and practices are not only continuing Japanese religious traditions, as scholar Jolyon Baraka Thomas has argued in his work Drawing on Tradition: Manga, Anime, and Religion in Contemporary Japan, but also influencing the mainstream audiences of Japan as well. ${ }^{90}$ Demographically speaking, the otaku are the main group that pop culture and its mass products are aimed at due to their likelihood of spending money on these products, and they are typically the ones who are most likely to purchase those pop culture products. Most revenue for these series comes from merchandise associated with the series. Specifically, the otaku are the ones who will complete sets of figurines, collect special editions, or purchase duplicates of items in contrast to a non-otaku who may only purchase an item on a whim, because it looks "cool," or because they find it "cute." With pop products being made available to all Japanese, and not just the otaku, many people are consuming these products that have distinct religious themes, ideas, and symbols. But, significantly, most Japanese do not display the same consumption behaviors and practices of the otaku.

In consideration of the role that religion has had on society, culture, and the economy, it will be of interest to see the ways in which these elements, economic and consumer in particular, have impacted religion. An examination of the socio-religious phenomenon of the otaku, religion, and pop culture in Japan, the research and conclusions may add to the growing field of pop culture studies, and hopefully, impact religious studies. However, there is a caveat to this research. This dissertation and the research that informs it does not reflect Japan as a whole. The otaku phenomenon only concerns a specific demographic group - a minority of young Japanese men who have

\footnotetext{
${ }^{90}$ See Jolyon Baraka Thomas, Drawing on Tradition: Manga, Anime, and Religion in Contemporary Japan, Honolulu: University of Hawai'i Press, 2012.
} 
access to Japanese popular culture as well as the income to support their hobbies and obsessions. This dissertation and its analysis and conclusions are not meant as criticisms of Japanese otaku or of Japan in general. Rather, the goals of this dissertation are to highlight these phenomena to present their relevance to further research in global fandom studies, religious studies, or popular culture studies. 


\section{CHAPTER TWO: HISTORICAL AND CULTURAL CONTEXTS OF RELIGION IN}

\section{JAPANESE CULTURE}

As with all contemporary cultures and societies, religion in Japan has played an influential role in both shaping and being affected by numerous historical and cultural events. The economic realities of Japan, notably during the Shōwa period (1926-1989), enabled contemporary forms of mass media consumption. This dissertation argues that the otaku consumption of pop products is a phenomenon that highlights a shifting of traditional ideas and practices inspired by Japanese religion. Rather than replacing religion, it should be noted that their consumption utilizes elements of Shintō, particularly with regard to concepts of kami and devotional practices.

Recently, within the last ten years or so, the otaku subculture has begun to show an influence on Shintō shrines and Buddhist temples as well. To contextualize this contemporary phenomenon, this chapter provides a brief overview of visual culture in Japan and examines the fluctuations in Japanese religious history to illustrate how Japanese religious habit and practice has shifted due to the influence of historical and cultural events. Visual culture resulted in the creation of the otaku and is itself rooted in ancient traditions. Historically, visual culture and religious powers are in constant fluctuation, influenced by dominant social and political powers. That said, Shintō and Buddhism have existed, for the most part, peacefully side-by-side, either in separate forms or syncretistic ones since the Nara period (710-794 CE) when Buddhism was first introduced into Japan. These two religions also impacted the early artistic influences on 
visual art that would eventually come full circle in what is now known as manga, which often features elements of Japanese religions.

This chapter includes an examination of the connection between the evolution of media and the tenuous position of people and things that shift from profane to sacred and back again. The evolution of illustrated media in Japanese visual culture has influenced and is confluent with traditional religious and historical antecedents that are now being seemingly combined in contemporary Japan. The otaku are a catalyst of sorts for some of the modern influences and it important to include background on the visual art that the otaku consume, tracing political power shifts, and laying out a historical and cultural context will provide a basis for understanding the otaku manifestation as a socio-religious phenomenon. Special attention is given to the shifting roles of the sacred and the profane, highlighting the ambiguous position that figures of devotion can occupy. A final note in this chapter also considers the relationship between modern Japanese society and religion, particularly Shintō.

\section{HISTORICAL ROOTS OF MANGA}

Well-known around the world, Japanese comics, known as manga, have roots dating back to ancient Japanese art. Japanese religious traditions, visual art, and visual culture are connected to ancient Japanese traditions found in Buddhist temples and Shintō shrines. Along with the aristocracy and samurai class, the viewing and ownership of illustrated scrolls was common among members of the clergy. ${ }^{91}$ During the Tokugawa period (1600-1868 CE) illustrated documents became mass-produced and rose in popularity through the proliferation of woodblock prints and, by the late nineteenth

\footnotetext{
${ }^{91}$ Kinko Ito, "A History of Manga in the context of Japanese Culture and Society," The Journal of Popular Culture 38.3 (2005): 458. See also, Frederik L. Schodt, Manga! Manga! The World of Japanese Comics, Tokyo: Kodansha, 1986, 32.
} 
century, published magazines. ${ }^{92}$

The popular subjects for early scrolls which were often religious in nature, as well as depicting scenes from the Heian period (794-1185 CE) text the Genji Monogatari (The Tale of Genji), historical battles, romance, and so on. The scrolls were read and viewed from right to left, which is how modern manga is read today. This section will provide a brief overview of manga in Japan to provide a baseline for the traditional roots of manga and its connection to Japanese culture.

Early Japanese visual art, as with manga today, contained humor, exaggerated action, and often satire. Manga and humor is traced back to the Horyuji Temple (c. 607 $\mathrm{CE}$ ), the oldest wooden structure in Japan, where "caricatures of people, animals, and 'grossly exaggerated phalli'" were found illustrated on the wooden planks in the ceiling of the temple in $1935 .^{93}$ These images could be considered graffiti, but they also qualify as manga, or "whimsical pictures." of twelfth-century scrolls known as the Chōju-jinbutsu-giga, or the "Animal Scrolls," which depict anthropomorphic animals engaging in a variety of activities. The Buddhist monk, Toba Sōjō (1053-1140 CE), is believed to have created these scrolls, which parodied "the decadent lifestyle of the Japanese upper class of the period." 95 The scrolls are ink and paint known as emakimono, or picture scrolls. One of the earliest non-

\footnotetext{
${ }^{92}$ The first magazine published in Japan was Seiyo-Zasshi, which was published in 1867. See Masahide Kanzaki, "History of Magazines in Japan: 1867-1988," The Web Kanzaki, 7 Jul 1996, Web, 14 Jun 2017. $<$ http://www.kanzaki.com/jpress/mag-history.html>

${ }^{93}$ Horyuji Temple, commissioned by Empress Suiko and Prince Shōtoku, constructed in $607 \mathrm{CE}$, burned down in $670 \mathrm{CE}$, and was eventually rebuilt in the eighth century. Kinko Ito, "A History of Manga in the context of Japanese Culture and Society," The Journal of Popular Culture 38.3 (2005): 458.

${ }^{94}$ Manga is written with the characters, 漫画. The first character “漫” can be translated as “whimsical” and the second character “画" can be translated as "pictures."

${ }^{95}$ Kinko Ito, "A History of Manga in the context of Japanese Culture and Society," 458.
} 
Buddhist emakimono depicts scenes from the Genji Monogatari. ${ }^{96}$

\section{PRINTING PRESS IN JAPAN}

Early copies of works, namely reproductions of literature, such as the Genji Monogatari, were copied by hand. There was also an early form of the printing press in Japan prior to the introduction of Gutenberg's printing press. This early form of the printing press, which relied on woodblocks, originated in China in the sixth century due to the influence and spread of Buddhism. ${ }^{97}$ Early Japanese works that were massproduced were often copies of Buddhist Sūtras, such as productions of the Lotus Sūtra in 1009. ${ }^{98}$ In the seventeenth century, historical and political documents began to be produced this way. For instance, the Keian Ofuregaki (The Regulations of Keian) (1646) or the Edo machijū sadame (Regulations for Edo) (1655). ${ }^{99}$ Japan was introduced to a movable type printing-press when the Jesuit missionaries imported a Western printing press in the late sixteenth century, which helped inspire further development of printing and visual culture in Japan. ${ }^{100}$ In late sixteenth century Japan, the printing press moved beyond Buddhist influence. ${ }^{101}$ Before assuming his role as shōgun and uniting Japan, Ieyasu Tokugawa (1543-1616), founder of the Tokugawa shōgunate, was instrumental in the formation of a Japanese native movable type that relied on wooden rather than metal type-pieces. He ordered the printing of numerous historical and political texts rather than

\footnotetext{
${ }^{96}$ See Haruo Shirane, Envisioning the Tale of Genji: Media, Gender, and Cultural Production, New York: Columbia University Press, 2008.

${ }^{97}$ Paulos Milkias, "The North-South Gap: Who is to Blame?," Developing the Global South: A United Nations Prescription for the Third Millennium, New York: Algora Publishing, 55.

${ }^{98}$ Tsien Tsuen-Hsuin, Science and Civilisation in China: Volume 5, Chemistry and Chemical Technology, Part I: Paper and Printing, Ed. John Needham, Cambridge: Cambridge University Press, 1985, 338-341.

${ }^{99}$ The Cambridge History of Japan: Early Modern Japan, Ed. John Whitney Hall, Cambridge: Cambridge University Press, 1988, 160.

${ }^{100}$ See Richard Lane, Images from the Floating World, the Japanese Print, Oxford: Oxford University Press, 1978, 33.

${ }^{101}$ Tsien Tsuen-Hsuin, Science and Civilisation in China, 338-341.
} 
Buddhist texts. In time, woodblocks were deemed more effective because they are more legible than handwritten documents and were used extensively for publishing in the midseventeenth century. ${ }^{102}$

\section{UKIYO-E AND COINING A TERM}

The precursor to modern day manga would come to be known as Toba-e, or Toba pictures, which was in reference to the Chōju-jinbutsu-giga. The Buddhist monk Toba intended for the Chōju-jinbutsu-giga to be used as a religious teaching tool ${ }^{103}$ After the popularity of his scrolls, any images that contained comedy were called Toba-e. ${ }^{104}$ These images became very popular and during the Tokugawa period (1600-1868 CE) when the rise of a middle class created a need for them to be entertained and have their own form of art. Calligraphy paintings and emakimono were, as mentioned earlier, restricted to the aristocracy, samurai class, and clergy due to sumptuary rules enforced by the Tokugawa shōgunate in an effort to maintain the superiority of the aristocracy. ${ }^{105}$ With the growth of a middle class, the demand for art and illustrated books grew. The term manga itself was not commonly used until the latter part of the eighteenth century, when it was first used in 1798 by Santō Kyōden's picture book, Shiji no yukikai [Seasonal Sketches]. ${ }^{106}$ The term was used again in 1814 when Aikawa Minwa's Manga Hyakujo [100 Girl Cartoons] and Katsushika Hokusai's Hokusai Manga were published. ${ }^{107}$ These published books, were often purchased by the members of the middle class, and featured illustrated

\footnotetext{
${ }^{102}$ See George Sansom, A History of Japan: 1334-1615, Stanford: Stanford University Press, 1961.

${ }^{103}$ Toba Sōjō was a Tendai Buddhist high priest. He was also an artist whose work was satirical and meant to be used as religious tools. See Louis-Frédéric, Japan Encyclopedia, trans. Käthe Roth, Cambridge: The Belknap Press of Harvard University Press, 2002, 967.

${ }^{104}$ Helen McCarthy, A Brief History of Manga, East Sussex; Ilex Press, 2014, 6.

${ }^{105}$ See Donald H. Shively, "Sumptuary Regulation and Status in Early Tokugawa Japan," Harvard Journal of Asiatic Studies 25 (1964): 123-164.

${ }^{106}$ Helen McCarthy, A Brief History of Manga, 6.

${ }^{107}$ Helen McCarthy, A Brief History of Manga, 7.
} 
woodblock prints known as ukiyo-e. These books and single prints were collected, displayed, and shared with guests, a small sign of how well traveled and tasteful the owner was.

These images were woodblock prints that were easily mass-produced and due to being relatively inexpensive to produce, mass consumed by the middle class. The ukiyo$e$, which means "floating world pictures," depicted scenes from popular plays or dancing geisha, most often located and associated with the registered red light districts. ${ }^{108}$ Those were not the only images depicted in ukiyo-e, and popular subjects included some of the earlier mentioned subjects for the emakimono, in addition to scenes from Kabuki theatre, ${ }^{109}$ popular Kabuki actors, landscapes, and scenes of everyday life among others. $^{110}$

The so-called "floating world" represented the rapid economic growth of the capital city of Edo, now modern day Tokyo. This rapid growth benefitted the merchant class who were considered to be in a lower socio-economic class during the Tokugawa period due to prejudice against the merchant class stemming from ideas found in Confucianism and Buddhism. ${ }^{111}$ As the merchants' wealth grew, they were able to spend money more freely in places like the floating world or purchase clothing that was

\footnotetext{
${ }^{108}$ The floating world was the demimonde of the Tokugawa period. The floating world was often the center of urban society and lifestyles that were deemed to be hedonistic.

${ }^{109}$ Kabuki is a traditional form of theatre in Japan that has roots in the kagura, a traditional dance performed at Shintō shrines. Actors may wear face paint, the costumes are brightly colored, and it is more fast-paced compared to Noh, another traditional form of Japanese theatre. See Ronald Cavaye, Kabuki: A Pocket Guide, North Clarendon: Tuttle Publishing, 1993.

${ }^{110}$ Despite the popularity and success of the ukiyo-e in Japan, many of these prints were often used to ship vases and fragile items to the West. Many Western artists, such as Vincent Van Gogh and Henri ToulouseLautrec, were inspired by the vibrant colors and simple lines of the prints and tried to copy them into their own style. This would eventually become Japonism in the 1870s.

${ }^{111}$ Confucianism and Buddhism do not encourage the pursuit of wealth, but at the most basic, focusing on self-cultivation. Hence the non-issue with the aristocracy and samurai living their lifestyles, they were already wealthy and focused on forms of self-cultivation, such as the samurai becoming leading calligraphers and masters of the tea ceremony.
} 
luxurious and showed off their wealth. They were able to indulge in various forms of entertainment, such as the kabuki theatre or an evening spent being entertained by geisha. Ukiyo-e were collected by this rising middle class and depicted scenes that they would have been familiar with. As pointed out by TOKI, a Japanese travel company specializing in "authentic Japanese traditional culture":

"Just as many of us loved to paper our walls with the likeness of our favorite movie stars, Edo Period collectors and theatre spectators collected images of their favorite Kabuki actors. Just as we purchase for loved ones postcards of cities and towns that we visit while on vacation, more and more citizens of Edo collected landscape ukiyo-e as they became wealthier and could take leisurely trips." 112

Similar to the otaku and most middle class consumers in contemporary Japan, the burgeoning middle-class of Tokugawa period Japan was indulging in mass-produced visual culture. The samurai and members of the aristocracy were indulging in high art, such as the tea ceremony and calligraphy, they could also afford to pay respected artisans to create custom works. The merchants and newly growing middle-class were also able to indulge in an art that was created for them and attuned to their tastes.

\section{NINETEENTH CENTURY JAPAN AND THE CREATION OF MANGA}

\section{MAGAZINES}

After the rising popularity of ukiyo-e prints during the Tokugawa period, Japan opened its borders to the West in 1854 after the arrival of Admiral Matthew C. Perry and his steamships. With the opening of Japan, woodblock prints began to slowly lose popularity as they were replaced with magazines. In 1848, a Dutch ship brought Gutenberg's printing press to Japan which had been purchased by Shōzō Motoki, who

\footnotetext{
${ }^{112}$ TOKI, "Perspectives on Japan's Pleasure Seeking Past: Discovering Ukiyo-E,” TOKI, 20 Feb 2016, Web, 1 Jun 2017. <http://www.toki.tokyo/blogt/2016/2/20/perspectives-on-japans-pleasure-seeking-pastdiscovering-ukiyo-e>
} 
was a Dutch interpreter for the port of Nagasaki. ${ }^{113}$ The press was used to reproduce and create a movable metal-type capable of creating a syllabic typeface, and in 1851-1852 Motoki used it to create a Dutch-Japanese dictionary. ${ }^{114}$ The printing press was further improved upon as Japan moved into the Meiji period.

In the Meiji period (1868-1912 CE), when Westerners were encouraged to come and help modernize Japan, one British expatriate, Charles Wirgman, helped found Japanese magazine Japan Punch in $1873 .{ }^{115}$ It was the first magazine of its kind in Japan, featured entirely in English, and included cartoons and satire concerning Japan and its growing foreign community in the latter part of the nineteenth century. Its audience would have been the expatriate community, but it was also available to any Anglophones and those who may have been a part of the flourishing intellectual groups of the Meiji period. ${ }^{116}$ This magazine would go on to inspire growing groups of artists in Japan, eventually serving as a model for Eshinbun Nipponchi [Picture Newspaper JaPonchi ] (1874), Japan's first cartoon magazine. ${ }^{117}$ The name itself of the magazine was a reference to Japan Punch. This magazine was followed by several other satirical magazines, such as Kisho Shimbun, a caricature magazine in 1875. Cartoons of this period were often used to critique the social and political climates of the Meiji period.

In 1895, the first Japanese magazine for children, Shōnen Sekai, or Boy's World, was published. The late nineteenth century also saw the rise of girls' magazines, known as shōjo zasshi, which would influence and establish aesthetic trends in contemporary

\footnotetext{
${ }^{113}$ Edward Mack, Manufacturing Modern Japanese Literature: Publishing, Prizes, and the Ascription of Literary Value, Durham: Duke University Press, 2010, 25.

${ }^{114}$ Edward Mack, Manufacturing Japanese Literature, 26.

115 Helen McCarthy, A Brief History of Manga, 8.

${ }^{116}$ During the Meiji period, the government encouraged and sent many young Japanese men to Europe to study, learning English and Western thought, with the idea that they would return to Japan to help modernize it. Scholars and intellectuals like Natsume Soseki and Yukichi Fukuzawa.

${ }^{117}$ Helen McCarthy, A Brief History of Manga, 10.
} 
manga. These magazines would contain stories and illustrations of young women, poetry, illustrated comics, and so on. ${ }^{118}$ In 1907, the first Japanese manga magazine for children, Shōnen Puck, was published and featured comics for children. Shōnen Sekai had included illustrations, but its main features were literature and a thematic focus on the First SinoJapanese War. Shōnen Puck was influenced by Western children's magazines and included longer illustrated comics that followed loose narratives. ${ }^{119}$ Manga magazines moved from loosely connected illustrations to short illustrated narratives.

As Japan grew in the prewar and postwar periods, new genres and manga magazines flourished. ${ }^{120}$ Works being produced during the 1930s and the Second World War were influenced by propaganda and nationalist ideologies. Two such manga magazines were Shōnen Club (1915) and Shōjo Club (1923), which originally contained children's stories of heroes and heroines in humorous situations and everyday adventures. As Japan began to move towards militarism and ultranationalism in the 1930s, many manga began to reflect the thought of the period. Manga began featuring stories of soldiers cheerfully wielding weapons and sacrificing themselves for the country. As Japan entered the Second World War, the government began to control and closely monitor the works and subjects being published. Manga characters carried the ideologies of State Shintō and the Japanese spirit.

\section{MEDIA AS A TOOL DURING THE RISE OF FASCISM AND NATIONALISM}

Just as manga began to reflect the rising militarism and ultranationalism of the 1930s, so did anime, or Japanese animation, begin to reflect these shifts. Anime

\footnotetext{
118 Nozomi Masuda, "Shojo Manga and Its Acceptance: What is the Power of Shojo Manga?," International Perspectives on Shojo and Shojo Manga: The Influence of Girl Culture, Ed. Masami Toku, New York: Routledge, 2015, 24-26.

${ }^{119}$ See Helen McCarthy, A Brief History of Manga, East Sussex; Ilex Press, 2014

${ }^{120}$ See Helen McCarthy, A Brief History of Manga, East Sussex; Ilex Press, 2014.
} 
originated in Japan in the early twentieth century and there were commercial showings of short animated film to the public in movie theaters across Japan, but early animation competed with foreign animation, such as animated shorts from Disney, and initially were not a profitable form of media. ${ }^{121}$ It is not until the 1930s when the Japanese government began to enforce nationalism through State Shintō that animation becomes more widespread. Animation was used to spread propaganda and films were commissioned by the military, such as 1943's animated film Momotarō's Sea Eagles, a reimagining of the attack on Pearl Harbor by folk hero Momotarō, directed by Mitsuyo Seo and commissioned by the navy. ${ }^{122}$ Nearly all Japanese, adults and children, saw propaganda films, such as Momotarō's Sea Eagles.

Momotarō, or Peach-Boy, was a popular hero in many of the animated propaganda films made during the Second World War. Momotarō is a young boy who, with the help of his animal companions, defeated ogres who had been plaguing nearby villages. He was a folk hero rooted in Japanese tradition whose image was carefully crafted and revised by the government to meet with nationalist ideas of Japan being superior. ${ }^{123}$ During WWII, Momotarō became a role model for young Japanese boys and as a symbol of what all Japanese should aspire to be. After the war, Momotarō would be revised again as a symbol of the Japanese spirit and as a reminder that the Japanese could rebuild. $^{124}$

\footnotetext{
${ }^{121}$ Japan had a similar system to Hollywood, with certain movie theater chains associated with specific movie studios. These theaters and the studio system began in the late 1920s and early 1930s.

${ }^{122}$ See Daisuke Miyao, "Before Anime: Animation and the Pure Film Movement in Pre-War Japan," Japan Forum 14.2 (2002): 191-209.

${ }^{123}$ The story of Momotarō is widely known to nearly all children in Japan as a popular story told during childhood. See Zilia Papp, "Monsters Reappearing in Great Yokai Wars, 1968-2005," Fear, Cultural Anxiety, and Transformation: Horror, Science Fiction, and Fantasy Films Remade, Eds. Scott A. Lukas and John Marmysz, Lanham: Lexington Books, 2010, 133.

${ }^{124}$ See John Dower, War Without Mercy: Pacific War, New York: Pantheon Books, 1986, 306.
} 
In addition to carefully constructing nationalist folk heroes, the WWII government also controlled the animation and comics being produced and commissioned. Comic artists were forced to join the Shin Nippon Mangaka Kyōkai (The New Cartoonists Association of Japan), which carefully constructed and controlled the images and ideas being distributed to children through Manga magazine, the association's official manga magazine. ${ }^{125}$ The propaganda was carefully crafted to depict heroes who were willing to sacrifice themselves for Japan, revered the Emperor, and who defeated the Western villain. Many of these works published during the war were heavily inspired by propaganda and State Shintō ideologies, being distributed and made available to both children and adults.

\section{MANGA AND ANIME IN POSTWAR JAPAN}

The period after war saw a rise in the production and publication of manga. As to be expected, many of the manga coming out after the end of WWII reflected the various social, cultural, and political events of the period. Kinko Ito points out that in the period after the war, the devastation of Japan had left many Japanese "starving for entertainment and humor" and that manga "was easily affordable, and the newly emerging civil society after the unconditional surrender and the seven-year U.S. occupation provided an abundance of topics for satire." ${ }^{126}$ It was also during the postwar period that the comics Sazae-san (Miss Sazae) (1946-1974) by Machiko Hasegawa and Tetsuwan Atomu (Mighty Atom) (1952-1968) by Osamu Tezuka became immensely popular. The eponymous characters reflected new sentiments and ideas as Japan began to rebuild after WWII. Sazae-san reflected the realities of a modern family in postwar Japan. Sazae-san's

\footnotetext{
${ }^{125}$ Rei Okamoto Inouye, "Theorizing Manga: Nationalism and Discourses on the Role of Wartime Manga," Mechademia 4: War/Time, Ed. Frenchy Lunning, Minneapolis: University of Minnesota Press, 2009, 30.

${ }^{126}$ Kinko Ito, "A History of Manga in the context of Japanese Culture and Society," 466.
} 
adventures were often topical and examined early Japanese feminist thought, with many comical situations arising due to Sazae-san's participation in a women's liberation group. ${ }^{127}$ Tetsuwan Atomu reflected the concerns and fears of nuclear weapons and weapons of mass destruction - not unlike those examined in the 1954 film Gojira, released in the West as Godzilla. ${ }^{128}$

Many works after the postwar period began to attempt serious narratives that often reflected the historical and cultural contexts of the period. Some works, like Sazaesan, were topical and examined life and struggles in postwar Japan. Science fiction grew in popularity after the war. Many works often examined and questioned nuclear power, human nature, and the effects of war. Tezuka's Tetsuwan Atomu was a popular example, as well as Tetsujin 28-gō (Iron Man Number 28) (1956), which centered on ten-year-old Shotaro Kaneda and his giant robot, Tetsujin 28. Like Tetsuwan Atomu, it examined weapons of destruction and was inspired by the weapons designed during WWII.

Tezuka and his work were especially important to the flourishing of manga and anime during the mid-1950s. In the 1950s, Tezuka's manga gained prominence among many Japanese who read his work. His presence was so prominent that Tetsuwan Atomu's première in 1963 is often credited as the first anime TV series, although it was actually a series called Otogi Manga Karenda, sometimes translated as Instant History, which had premiered in $1961 .^{129}$ Prior to the popularity of Tezuka's Tetsuwan Atomu, anime had been released annually as feature-length films in theaters. In due time,

\footnotetext{
${ }^{127}$ Machiko Hasegawa is credited as one of the first female comic artists in Japan. See Frederik L. Schodt, "Reading the Comics," The Wilson Quarterly 9.3 (1985): 64. In 1940s Japan, women's liberation groups and feminism were in conflict with traditional Japanese patriarchy. One such conflict was that men should be the head of the household and in Sazae-san, she often bosses her husband around rather than being subservient to him.

${ }^{128}$ Tetsuwan Atomu was translated and released in the West as Astro Boy.

${ }^{129}$ See Jonathan Clements, Anime: A History, London: British Film Institute, 2013.
} 
Tetsuwan Atomu's transition from a manga to an anime series would become a common model among the most popular manga works.

\section{MANGA FOR THE MATURE READER}

Since the 1950s manga has grown to make up a significant portion of Japanese publications. ${ }^{130}$ Between 1950 and 1969, the readership of manga was growing and a focus grew on marketing comics specifically for boys, known as shōnen manga, and specifically for girls, shōjo manga. ${ }^{131}$ Despite manga being marketed specifically for boys and girls, there is a large cross-readership. Manga for boys often focused on adventure and action, whereas girls' manga featured romance and magical heroines. In the late fifties up until the early eighties, another form of manga became popular with college students known as gekiga, or "drama pictures.” Gekiga were drawn realistically compared to the cartoonish illustrations in early manga, and often forgo humor in favor of realism and drama. ${ }^{132}$ This type of manga was also often reflective of the political and social criticisms of the late sixties and throughout the seventies, often concerning issues such as government corruption or sexuality. Tezuka also began to make his own response to gekiga, with $M W$ (1976-1978), which depicted gritty themes, sexually explicit relationships, and violence. Other prominent series of the gekiga style was Kozure Ōkami (Lone Wolf and Cub) (1970-1976) by Kazuo Koike and Goseki Kojima.

According to Kinko Ito, many who had grown up reading manga during the fifties and sixties, specifically young men, were "becoming adults, and they needed a different

\footnotetext{
${ }^{130}$ See Sharon Kinsella, Adult Manga: Culture and Power in Contemporary Japanese Society, Honolulu: University of Hawai i Press, 2000. See also Frederik L. Schodt, Dreamland Japan: Writings on Modern Manga, Berkeley; Stone Bridge Press, 1996.

${ }^{131}$ Frederik L. Schodt, Manga! Manga!: The World of Japanese Comics, New York: Kodansha, 1986, 6267.

${ }^{132}$ Kinko Ito, “A History of Manga in the context of Japanese Culture and Society,” 467.
} 
type of manga entertainment" as they "could not live without reading manga."133 These same men went on to create new manga magazines that catered to their growing sensibilities, and creating new genres of manga, such as kyōyō manga, or academic or educational manga. ${ }^{134}$ As Kinko Ito states, "The world of Japanese manga has always revolved around men — male artists, editors, and publishers." ${ }^{135}$ Women were no strangers to creating and publishing manga, in the 1970s, many female manga artists began making comics for women that depicted male homosexuality in shōjo manga. Ito explains, "aesthetically drawn young boys are very popular among the Japanese girls and women" and that in Japan, "there has been a long tradition of male homosexuality."136 Many reasons have been attributed to the popularity of male homosexuality with females. Two possible reasons are that women are able to subvert the patriarchy through creative works or that women are oppressed by the patriarchy and these types of works "provides a glimpse into the attainment and preservation of a relationship based upon mutual trust and egalitarian values. ${ }^{\prime 137}$ In the early 1980 s, men were also writing girls' manga and creating niche manga magazines like Manga Burikko, which contained shōjo manga that were aimed at men. Male readers, often otaku, are attracted to the aesthetically pleasing depictions of the female characters in shöjo manga. Most often this fetishism is known as moe and will be discussed further in Chapter Four.

\footnotetext{
${ }^{133}$ Kinko Ito, "A History of Manga in the context of Japanese Culture and Society," 469.

${ }^{134}$ Kinko Ito, "A History of Manga in the context of Japanese Culture and Society," 471.

${ }^{135}$ Kinko Ito, "A History of Manga in the context of Japanese Culture and Society," 471.

${ }^{136}$ Kinko Ito, "A History of Manga in the context of Japanese Culture and Society,” 471.

${ }^{137}$ Anne Kustritz, "Slashing the Romance Narrative," The Journal of American Culture 26.3 (2003): 380. See also Akiko Mizoguchi, "Male-Male Romance by and for Women in Japan: A History and the Subgenres of 'Yaoi' Fictions," U.S.-Japan Women's Journal No. 25 (2003): 49-75.
} 


\section{MANGA AND ANIME DURING AND AFTER THE BUBBLE ECONOMY OF THE 1980s}

The 1980s saw a rise in the popularity of manga, it also saw the rise of an affluent Japan. As with most countries during the eighties, Japan was noted for its excessive materialism and many people began to become disenchanted with the materialism of the period and alienation that came out of materialism. This period of affluence and the rise of a larger middle class saw the growth of an amateur manga medium. This medium, known as döjinshi, are fanmade comics and this growth was "accounted for by the arrival of teenage artists from privileged backgrounds at amateur manga conventions." ${ }^{" 138}$ This growth affected the various themes and genres explored in manga and anime as well.

Throughout this period, anime and manga began to touch on themes that examined the apocalypse, political and social conflict, and religious/cult groups among other themes. In gekiga, the anomie and dislocation that people felt were aftereffects from the war and the crass materialism of the 1980s. Manga artists look towards the past, romanticizing it, and examine religious and supernatural elements in various settings, both past and present.

Religion was often present in manga, typically in reference to everyday life, such as visiting Shintō shrines or the off-handed mention of a character being a miko, a priestess, at a shrine. In the 1990s and 2000s, many series freely used kami and bodhisattvas from Shintō and Buddhism as characters or they utilized elements and themes from both religions. The manga InuYasha by Rumiko Takahashi involved a female protagonist who was the reincarnation of a miko from medieval Japan and who time-travels to a medieval Japan inhabited by kami and yōkai, or demons and ghosts. The

${ }^{138}$ Sharon Kinsella, Adult Manga: Culture and Power in Contemporary Japanese Society, 111. 
series was immensely popular and published from 1997 to 2008 in the manga magazine Weekly Shōnen Sunday.

During the 1990s, the economic bubble that had been growing during the 1980s burst and Japan experienced a recession that is still affecting the country today. It is also during the 1990s that the Internet becomes accessible to the public and subsequently begins to impact the concept of community and communication. The growth of the internet and access to it begins to impact the subculture of the otaku, the fans commonly associated with manga and anime. The internet begins to impact anime and manga itself, presenting philosophical questions of humanity and technology, such as those examined in Kōkaku Kidōtai (Ghost in the Shell). ${ }^{139}$ Religion and technology also begin to be examined in series like Shinseiki Evangerion (Neon Genesis Evangelion), which is often recognized as the one of the anime that popularized anime and made it mainstream. ${ }^{140}$ Shinseiki Evangerion was created during the recession in 1995 and despite the decreased animation production at the time, went on to inspire new standards for Japanese anime. ${ }^{141}$ Due to the series' popularity and the last two episodes of the original television series being considered controversial, many fans "jammed the network site on the Internet" and "even major newspapers and literary magazines chimed in to offer comments" on the

\footnotetext{
${ }^{139}$ The series title translates as "Mobile Armored Riot Police," but Masamune Shirow wanted the title to be "Ghost in the Shell," and that was the title used in the Western translation of the work. Ghost in the Shell originated as a manga from 1989 to 1990, and the first feature length anime was released in 1995. American production company DreamWorks released a live-action version in 2017 with as an American science fiction film.

${ }^{140}$ Shinseiki Evangerion originally aired as a 26-episode anime from 1995-1996. There have been six Shinseiki Evangerion anime films as of 2012. In addition to manga, the series has also been created into numerous video games and other media. Most notably, Shinseiki Evangerion is well known for being created by otaku, specifically Studio Gainax and director Hideaki Anno, and holds a persisting popularity within otaku subculture. Some scholars, such as Hiroki Azuma credit Shinseiki Evangerion with bringing otaku culture to mainstream attention; see Hiroki Azuma, Otaku: Japan's Database Animals, Minneapolis: University of Minnesota Press, 2009.

${ }^{141}$ See Tim Hornyak, "Is 'Pacific Rim' a Retelling of Japanese Anime ‘Evangelion'?," CNET, 16 Jul 2013, Web, 15 Jul 2017. <https://www.cnet.com/news/is-pacific-rim-a-retelling-of-japanese-anime-evangelion/>
} 
series. ${ }^{142}$ The rising popularity and creation of series like InuYasha, Kōkaku Kidotai, and Shinseiki Evangerion, signals a critical stage in manga and anime that acts as a catalyst for the religious dimensions of the otaku phenomenon that this dissertation is examining.

\section{ANIME AND MANGA'S INFLUENCE ON CONTEMPORARY JAPAN}

As technology grew in the 2000 s, media began to change and expand. With growing social media and online message boards, the space in which anime and manga existed could be expanded. People could easily share or recommended series to each other through electronic communication. The otaku could now communicate outside of editorials in manga magazines or waiting to go to anime and manga conventions like Comiket. ${ }^{143}$ With the growth of media and technology, the existence of the otaku became dependent on both to express themselves and would go on to create new online communities to express themselves.

In 2003, Kagami Yoshimizu's Lucky «̧Star was published in Comptiq magazine, and is still currently being published. ${ }^{144}$ Lucky $\lesssim$ Star follows the everyday lives of four high school girls and often makes references to otaku subculture and pop culture in general. The series gained enough popularity with its readers that it was turned into an anime in 2007. As the anime aired on television, many otaku and fans took to Twitter to discuss the series. Through message boards and their own research, fans discovered that Lucky itstar's fictional landmark, the Takanomiya Shrine, was based on the real life location of the Washinomiya Shrine in Kuki, Saitama, Japan. Within the same year,

\footnotetext{
142 Morio Watanabe, “Imagery and War in Japan: 1995," Perilous Memories: The Asia-Pacific War(s), Eds. T. Fujitani, Geoffrey M. White, and Lisa Yoneyama, Durham: Duke University Press, 2001, 147.

${ }^{143}$ Comiket is a large comic convention in Japan where fans gather to purchase merchandise, perform cosplay, and so on.

${ }^{144}$ The series has also been briefly featured in several other manga magazines, such as Newtype, Comp Ace, Shōnen Ace, and so on.
} 
Newtype magazine ran an article detailing how to locate the shrine, as well as other various locations featured within the series. This connection of certain locations in visual art is reminiscent of the ukiyo-e prints that merchants and commoners would collect on their journeys to other towns and cities. Rather than being a status symbol of their wealth to travel as it once was for merchants, the otaku visit the locations depicted in the visual art they consume, to make connections with their pop culture figures in a pilgrimage-like journey they refer to as "seichi junrei," or pilgrimage to a sacred place, which will be analyzed further in Chapter Four.

In 2012, Love Live! was published as a multimedia project in Dengeki G's Magazine, coupled with both animation studio Sunrise and the music label Lantis. In 2013, unlike Lucky $\lesssim$ Star, Love Live! originated as an anime first, and then later featured a manga adaptation. The series has grown in popularity and features the Kanda Shrine, a Shintō shrine in Akihabara, Tokyo, Japan. Unlike Lucky $\_$Star, Love Live! does not use a fictional landmark, and features the Kanda Shrine where the protagonists practice their dance acts. The Kanda Shrine went so far as to name one of the protagonists, Nozomi Tōjō the official mascot of the shrine. ${ }^{145}$

Due to the influence and advancements of social media and internet communities, there is a growing connection of anime and manga series to real life locations, which include religious sites, such as the Washinomiya Shrine in Lucky 2 Star and the Kanda Shrine in Love Live! Contemporary access to advancing technology has influenced the comic industry, not just fans sharing locations and places connected to their favorite series. Many comic artists have begun using the Internet and digital technology to create

\footnotetext{
145 神田明神(Kanda_Myoujin), “Kandamyoujin shrine announces adoption of anime character as official mascot," 2 Jan 2015, 10:33 a.m., Tweet.
} 
manga and distribute it. There are a growing number of ways to read manga electronically. Most manga magazines have affiliated websites and are active on social media. There are also sites like Comico, which are entirely online and offer users the opportunity to read manga online without page breaks. With the popularity and ease of access to mobile devices, there are also phone apps, such as Line Manga, which provide users access to online manga. ${ }^{146}$ The expansions of these websites, social media, and online communication in general provide the otaku a way to communicate and create new communities. Members of the otaku subculture are dependent on the media and they play a role in driving mainstream culture and consumerism.

Manga still makes up a large portion of the Japanese publishing industry. It also influences popular culture on many levels. Manga start out serialized in manga magazines and then are collected into volumes known as tankōbon, a term which can be translated as "standalone" or "independent book." Most manga after some time will get an anime adaptation, especially if they are popular. The anime adaptations typically feature well-known voice actors, アイドル (pop idols) ${ }^{147}$ or groups that perform music for the anime, and drama CDs. This then typically branches off into figurines, a movie, and live-action film adaptations if the series proves to be popular. Sometimes, the series can also be adapted to become a video game, like those of the Love Live! series. ${ }^{148}$

Manga and its several antecedents serve as a medium between the early art and

\footnotetext{
${ }^{146}$ See Akky Akimoto, "Digital Manga Giving Print a Run for Its Money," "Life," The Japan Times, 11 Oct 2014, Web, 15 Jul 2017. <http://www.japantimes.co.jp/life/2014/10/11/digital/digital-manga-givingprint-run-money/\#.WWz_ZNPyuRs>

147 アイドル literally means “idol” and commonly refers to media personalities especially talent agencies that discover and promote them. There are other types of aidoru, but they are specified by their role, such as グラビアアイドル [gravure aidoru] who are women that appear in men's magazines.

${ }^{148}$ In 2013, Love Live! School Idol Festival was released for the iPhone. The game uses rhythm game and visual novel elements.
} 
visual culture of Japan to contemporary popular culture. There is also something to be said of the fact that manga often reflects the cultural, social, and political elements at the time the works are published. None of this is a break with the past, rather it is becoming a new phenomenon that has antecedents in ancient Japan.

\section{SHINTŌ}

Shintō is widely considered the indigenous religion of Japan, and unlike many other religions, has no founders or specific doctrines. Shintō morals are not informed by an overarching philosophical system such as those found in other Eastern traditions, like Confucianism or Buddhism. In Shintō, one is expected to do things the "right" way or not do them at all. ${ }^{149}$ There is an emphasis on orthopraxy rather than orthodoxy-an emphasis on practice and action rather than belief. This notion of doing things the right way is often associated with maintaining harmony with the kami, which are spirits or deities that are often prayed to or venerated. Considering that the concept of kami permeates Japanese daily life, Robert N. Bellah recounts that the divine permeation of everyday life results in "a very high percentage of acts in social life [being] of a sacred or semi-sacred nature" and failure "to perform them or performing them incorrectly" would be morally wrong as well as potentially sacrilegious, requiring divine sanction or ritual purification. ${ }^{150}$ In Shintō practice, a person is expected to perform "good" actions at all times, such as helping others or adhering to social protocol.

As one is always expected to behave accordingly, the Japanese are always Shintō,

\footnotetext{
${ }^{149}$ Shikata, "the way of doing things," is the idea that the Japanese do things the way they are supposed to be done. One is always being mindful and maintaining harmony in society and the universe. See Martin J. Gannon and Rajnandini Pillai, Understanding Global Cultures: Metaphorical Journeys through 34 Nations, Clusters of Nations, Continents, \& Diversity, Thousand Oaks: SAGE Publications, 2016, 40-42. ${ }^{150}$ Robert N. Bellah, Tokugawa Religion: The Cultural Roots of Modern Japan. New York: The Free Press, $1985,7$.
} 
regardless of whether they practice it. A unique feature of Shintō is that one cannot convert to it, but be born into it. Shintō is "inextricably interwoven with the fabric of Japanese customs and ways of thinking," and is impossible to separate from the communal and national life of the Japanese. ${ }^{151}$ Despite its intricate link to Japanese identity, many scholars, such as Sokyo Ono, a Lecturer for the Association of Shintō Shrines, feel Shintō does have universality to it in terms of its potential to enrich lives. ${ }^{152}$

\section{ROUTINIZATION OF SHINTŌ IN PRE-MEIJI JAPAN}

To differentiate Shintō from its predecessor religions, which had been an amalgamation of various folk religions, efforts were made to separate an authentic Japanese religion from the new foreign religion, Buddhism. This resulted in the consolidation of Shintō. As mentioned earlier, Shintō does not have an official founder, nor sacred texts, such as the Tripitaka and the various sutras found in Buddhism. Though not sacred texts, the Kojiki and the Nihon Shoki are meant to be critical historical sources that tell of the foundation of the Imperial Family and Japan, including the creation of Japan by the creator kami Inzanagi and Izanami. ${ }^{153}$

The historical and authoritative texts the Kojiki and the Nihon Shoki were compiled and edited by the chronicler $\overline{\mathrm{O}}$ no Yasumaro in 711-712 $\mathrm{CE}$ and $720 \mathrm{CE}$ at the request of Empress Gemmei. The texts were styled on the historical records used by the Chinese courts in ancient China. In a similar fashion, Japanese court scholars and officials wanted to provide records of historical matters, such as the creation of Japan and the "unbroken line" of succession of Japanese emperors. These texts also provide a

\footnotetext{
${ }^{151}$ Sokyo Ono, Shintō: The Kami Way, 111.

152 Sokyo Ono, Shintō: The Kami Way, 112.

${ }^{153}$ See Yasumaro Ō no, The Kojiki: Records of Ancient Matters, Trans. B.H. Chamberlain, North Clarendon: Tuttle Publishing, 1982, Volume I. See also Nihongi: Chronicles of Japan from the Earliest of Times to A.D. 697, Trans. W.G. Aston, North Clarendon: Tuttle Publishing, 2011, 1-64.
} 
historical background for much of Shintō, especially regarding the development of importance of the kami. For instance, the Nihon Shoki notes that Emperor Yomei "believed in the law of Buddhism and revered the way of the kami." ${ }^{154}$ This text also records the first recorded use of the term "Shintō," written as Shindō, ${ }^{155}$ in the sixth century of the Common Era. ${ }^{156}$ Official Shintō practices and rituals were recorded in these texts, which provided a history of Japan and the notion of the synthesis of Japan's mythical origins that intertwined with the lineage of the Imperial Family. Thence, two of the prominent historical influences on the development of Shintō are the previously mentioned importation of Buddhism from China and Korea, and the Japanese court modeling itself on the Chinese court. The creation of the Japanese court was also linked and influenced by the compiling of historical records, the Kojiki and the Nihon Shoki.

\section{RELIGION IN JAPAN}

This section includes a brief discussion of historical events associated with religion to highlight the roots of religious tradition in Japan. Besides Shintō, one influential religion that Shintō often syncretized with was Buddhism. Many Buddhist missionaries from China and Korea considered many of the kami to be bodhisattvas, often considered Buddhist saints, and Shintō priests and priestesses viewed the bodhisattvas as great kami. ${ }^{157}$ This concept of the spirits shared by both religions highlights one of the many syncretistic elements of Shintō, and to an extent, Buddhism.

\footnotetext{
${ }^{154}$ Stuart D.B. Picken, Essentials of Shintō: An Analytical Guide to Principal Teachings, Westport: Greenwood Press, 1994, xxi.

${ }^{155}$ Written with the characters 神, shin meaning spirit or god, and 道, $d \bar{o}$ meaning path or way, Shintō can be translated as Path of the Gods or Way of the Gods. See Sokyo Ono, Shintō: The Kami Way, 2.

${ }^{156}$ Stuart D.B. Picken, Essentials of Shintō: An Analytical Guide to Principal Teachings, xxii.

${ }^{157}$ This idea is linked with the idea of honji suijaku, which relates to the notion that the Japanese who practiced Shintō viewed the Buddha as a kami or that the Buddhists viewed the kami as bodhisattvas who were utilizing upaya to appeal to the Japanese mind.

See Mark Teeuwen and Fabio Rambelli, eds. Buddhas and Kami in Japan: Honji Suijaku as Combinatory Paradigm, London: Routledge, 2002.
} 
As both kami and bodhisattvas were considered important spirits who looked out for humanity, they also served as figures of reverence and devotion in their respective traditions. However, the devotion to figures, such as the kami, existed prior to the introduction of Buddhism and the organization of Shintō in the sixth and seventh centuries in the form of deities associated with clans and areas of land. Additionally, Shintō shares similarities with Taoist ideas of maintaining harmony with nature, in addition to the Buddhist ideas of dependent origination and elements of the Eightfold Path, such as right intentions and right mindfulness when doing things the right way. ${ }^{158}$

Due to a warrior-based political power during the Tokugawa period, Buddhism was ultimately established as Japan's main religion, specifically Zen Buddhism, which benefitted the warrior class and the ruling power's political needs. This form of Buddhism "was seen almost as a system of training which aided in the self-abnegating performance of actions expressing loyalty to one's lord" and thus, strengthened the position of the shōgun ${ }^{159}$ and his daimyō, who were the feudal lords serving under the shōgun. ${ }^{160}$ With patronage from the shōgunate, many Buddhist temples and monasteries grew in power. Land, money, clothing, and food were donated to the temples from the shōgunate, aristocracy, and the commoners and peasants. ${ }^{161}$ In contrast, other religions were viewed with suspicion—especially non-Japanese traditions, such as Christianity. Introduced in the mid-sixteenth century by Portuguese Jesuits, Christianity was

\footnotetext{
${ }^{158}$ See J. Isamu Yamamoto, Buddhism, Taoism, and Other Far Eastern Religions, Ed. Alan W. Gomes, Grand Rapids: Zondervan, 1998, 15-30.

${ }^{159}$ Written with the characters 将軍, shōgun translates as "general" and literally means "military commander." They also have the power to rule in the Emperor's stead. This government was also known as the bakufu, which translates to "office in a tent" or "field headquarters" - the place where a general would make important decisions. See footnote 13 in Robert N. Bellah, Tokugawa Religion: The Cultural Roots of Modern Japan, New York: The Free Press, 1985, 58.

${ }^{160}$ Robert N. Bellah, Tokugawa Religion, 17.

${ }^{161}$ H. Bryon Earhart, Japanese Religion: Unity and Diversity, Belmont: Cengage Learning, 2004, 145-147.
} 
viewed as a threat to both the shōgunate's power and the island of Japan itself. ${ }^{162}$ Unlike his mentor Nobunaga Oda, who was interested in Western culture and a patron of the Jesuits, Ieyasu Tokugawa viewed the Jesuit missionaries as a threat. ${ }^{163}$ Tokugawa's other mentor Hideyoshi Toyotomi, and Tokugawa himself, viewed the Christian religion with suspicion because the "First Commandment demanded exclusive loyalty to a jealous God." ${ }^{164}$ Due to the threat of Christianity, Tokugawa issued a decree, known as the Christian Expulsion Edict, in 1614 demanding that the Jesuit missionaries leave Japan, and claiming that Christianity influenced people to "contravene governmental regulations, traduce Shintō, calumniate the True Law, destroy righteousness, [and] corrupt goodness." ${ }^{165}$ To further combat Christianity, the Tokugawa shōgunate promoted Buddhism and all Japanese denizens were required to register with local temples so that priests might provide proof of approved religious affiliation. ${ }^{166} 167$

\section{KAMI TYPES}

Though Shintō shares some similarities with Buddhism and Taoism, it also has its own unique features. One such feature of Shintō is the belief in kami who permeate all things. The term kami, which can be translated as "spirit" or "god," are an important element of Shintō. The kami are the spiritual beings that represent elements of nature, humans who performed great deeds, natural objects and implements, or extraordinary

\footnotetext{
162 Japanese Religion: Unity and Diversity, 178.

${ }^{163}$ Ieyasu Tokugawa helped to unite Japan politically through the efforts of himself, Nobunaga Oda, and Hideyoshi Toyotomi during the Azuchi-Momoyama period (c. 1573-1600 CE), which was the final period of the Sengoku period (c. 1497- c. 1600 CE) - also known as the Warring States period. See James L. McClain, Japan: A Modern History, New York: W.W. Norton \& Company, 2002, 18-21.

${ }^{164}$ James L. McClain, Japan: A Modern History, New York: W.W. Norton \& Company, 2002, 43.

${ }^{165}$ Ronald P. Dore, Shinohata: A Portrait of a Japanese Village, New York: Pantheon Books, $1978,65$.

${ }^{166}$ Robert N. Bellah, Tokugawa Religion, 51.

167 This registration is known as the danka seido, or the terauke seido because of the certificates issued by Buddhist temples in the Tokugawa period that proved a citizen was not Christian.
} 
things. ${ }^{168}$ Some Japanese scholars, such as Sokyo Ono, claim, "Japanese people themselves do not have a clear idea regarding the kami. They are aware of the kami intuitively at the depth of their consciousness and communicate with the kami directly without having formed the kami-idea conceptually or theologically." The nature of the kami itself is vague. In Shintō, nature and natural formations are extremely important and at its simplest, Shintō is the idea that mankind will maintain a harmony with nature, among humanity, and with kami. Shintō practitioners may pray to the kami for various reasons, such as good health or a good harvest, as well as visiting shrines associated with various kami to ask for favors or have blessings bestowed upon them.

\section{CLAN AND IMPERIAL KAMI}

Prior to the introduction of Buddhism and the official recognition of Shintō as an indigenous religion in $660 \mathrm{CE}$, according to the Kojiki and the Nihon Shoki, ${ }^{169}$ Japanese society was organized in clans that occupied various regions throughout the country. During the Kofun period (250-538 CE), uji, or family clans, were integral economic, social, and political units. These clans practiced ancestor worship, revering the ancestors who had led the clan. Each clan had an ujigami, or family spirit, who provided guidance and protection for clan members. The leader of each clan would offer prayer and worship to the ujigami. The chieftain unified those in his clan, and "all members of the clan had both the right and obligation to participate and, according to the rules of some, to

\footnotetext{
${ }^{168}$ See Brian Bocking, A Popular Dictionary of Shintō, Surrey: Curzon, 1996, 84-85.

${ }^{169}$ Written during the Nara period (710-794 CE), the historical records of the Nihon Shoki lists 552 CE, during the Asuka period (538-710 CE), as the official introduction of Buddhism to Japan from Korea, although there had been Buddhist missionaries from China during Kofun period (250-538 CE). The period in which the Nihon Shoki was written, as well as another historical text the Kojiki, was also the first time that Shintō practices were recorded and codified. The historical texts list $660 \mathrm{CE}$ as the official date that Shintō was established. The term Shindō, was recorded as being first used in the sixth century. See Stuart D.B. Picken, Essentials of Shintō: An Analytical Guide to Principal Teachings, Westport: Greenwood Press, 1994, xxi.
} 
officiate shrine functions. ${ }^{170}$ Similar to the role of the Emperor in later periods, the head of the clan was responsible for ensuring proper rituals and prayers to the ujigami for good harvests, as early Japan was an agricultural society. ${ }^{171}$

After the Heian period (794-1185 CE), the term ujigami subsequently came to refer to other types of kami, as the ujigami became the tutelary kami of the community as a whole rather than only members of particular clans. ${ }^{172}$ This transition correlated with a shift in social structure. As people moved outside of their ancestral lands into new domains, they left behind old traditions for new ones. After the Heian period, familycentered society shifted into a manorial system, in which the nobility and temples possessed private lands, typically given as gifts from the Emperor.

This shift from public to private lands led to the tribal ujigami falling out of favor, as many nobles did not share the same ujigami as their warriors or peasants. With this flourishing of private estates known as shōen, "estate owners began to set up shrines to kami whom they would venerate not as ancestral deities but as guardian deities (chinjugami) of those estates. In this they were inspired by the long-established examples of deities who guarded temples and castles." ${ }^{\prime 13}$ These guardian deities, known as chinju, and later chinjugami, were tutelary kami that served as guardians of the village or given area. ${ }^{174}$ During the Muromachi period (1336-1573 CE), the kami were enshrined as guardian deities along with the ujigami. At all times, the ruling power or social structure,

\footnotetext{
${ }^{170}$ Sokyo Ono, Shintō: The Kami Way, 46.

${ }^{171}$ For further information on the ujigami and political structures within early Japan, see "Ancient and Classical Japan: The Dawn of Shintō" in Ito Satoshi, Endo Jun, and Mori Mizue, Shintō: A Short History, Ed. Inoue Nobutaka, Trans. Mark Teeuwen and John Breen, New York: RoutledgeCurzon, 2003, 12-62.

${ }^{172}$ See Ito Satoshi, Endo Jun, and Mori Mizue, Shintō: A Short History, Ed. Inoue Nobutaka, Trans. Mark Teeuwen and John Breen, New York: RoutledgeCurzon, 2003, 51-60.

${ }^{173}$ Inoue Nobutaka and Endo Jun, Shintō: A Short History, Trans. Mark Teeuwen and John Breen, New York: RoutledgeCurzon, 2003, 126.

${ }^{174}$ Written as 鎮守 chinju, or 鎮守神, chinjugami and can be translated as "tutelary god" and "tutelary god spirit" respectively.
} 
clans and leaders were important for the spread of various kami and religious practices, particularly prayer at shrines and the erection of altars devoted to the supplication of the kami.

The connection between the kami and ancestor veneration continues to this day. Today modern Japanese, including the otaku, are linked to their local Shintō shrine. Historically, in some regions of Japan, when a person passed away they would be recognized as a ji-kami, or land kami, thirty years after their death. ${ }^{175}$ Today, despite Japan no longer being socially organized according to clans, when a child is born, their name is entered into the local Shintō shrine's registry and the child becomes, along with the other residents of the community, an ujiko, or "clan child." ${ }^{, 176}$ When an individual dies, they become a part of the ujigami. Thus, the idea of family and a Shintō identity still permeates much of contemporary Japan.

Politically speaking, among the most influential families and individuals in Japanese history are the Imperial Family and the Emperor. Until the Sengoku period (c. 1497-c. $1600 \mathrm{CE}$ ), various clans would politically maneuver their daughters to be married to the Emperor, so that their clan would be tied to the imperial line. By marrying their daughters to the Emperor, the family would be able to gain influence and to further their own political agendas.

As the Japanese imperial court was being modeled on and influenced by Chinese court custom and structure, the Emperor remained a central figure. Subsequently, it was his relation to the Imperial kami, Amaterasu that highlighted his importance to the kami and, thus, his position as ruler. The Kojiki and the Nihon Shoki provided genealogies of

\footnotetext{
${ }^{175}$ Stuart D.B. Picken, Essentials of Shintō: An Analytical Guide to Principal Teachings, 212.

${ }^{176}$ See Appendix B for discussion of witnessing two child blessings at two Shintō shrines.
} 
his role within the imperial line, relating his connection to not only Amaterasu, but the creator kami themselves, Izanagi and Izanami, who had created Amaterasu. In addition to detailing the creation of Japan and the kami, the Kojiki and the Nihon Shoki detailed the good and bad qualities of each Emperor, including their religious and political roles. $\mathrm{He}$ was the first, and highest, priest of Shintō as well as a direct descendant of Amaterasu, the sun kami. As such, his job was to ensure proper rituals and rites performed for the good of the nation. The role of the Emperor as "first priest" is expressed in the myth that Amaterasu bequeathed three sacred treasures, known as the Sanshu no shinki, or "the three imperial regalia," to her descendant and the first Emperor of Japan, Emperor Jimmu to prove his relation to her. ${ }^{177}$

\section{NATURE AND NATURAL KAMI}

As an animistic religion, Shintō has a great reverence for nature. Animism is the belief that non-human entities possess a spirit or life force- that a spirit permeates all things. ${ }^{178}$ An example would be Mt. Fuji, which is sometimes considered a kami. Natural objects and implements such as large trees or rocks can be regarded kami as well, and are most often viewed as a place where kami dwell. In turn, the natural object will be marked with a shimenawa, or enclosing rope, that marks the natural formation as a sacred space. ${ }^{179}$ These sacred spaces exist all over Japan, including the most populated cities, and are recognized and inherently understood by both otaku and the general public.

\footnotetext{
${ }^{177}$ Sanshu no shinki, the Three Imperial Regalia of Japan are also known as the Three Sacred Treasures of Japan. The regalia consists of a jewel, sword, and mirror, known as the Yasakani no Magatama, Kusanagi, and the Yata no Kagami respectively. These three items represent primary virtues of benevolence, valor, and wisdom. For more on the origins of these items, see the Nihon Shoki and the Kojiki. See Brian Bocking, A Popular Dictionary of Shintō, Surrey: Curzon, 1996, 154.

${ }^{178}$ See Martin D. Stringer, "Rethinking Animism: Thoughts from the Infancy of our Discipline," Journal of the Royal Anthropological Institute 5.4 (1999): 541-556.

${ }^{179}$ See Brian Bocking, A Popular Dictionary of Shintō, Surrey: Curzon, 1996, 164. See Appendix A Figure 2.1.
} 


\section{DEIFICATION OF PEOPLE AND THINGS}

Although it may seem debatable that humans, or objects, could become recognized as kami, Japan has a history of deifying humans after their death, not to mention including objects thought to possess a great spirit. Typically, humans that were deified often performed some great deeds or were great patrons of the arts. These deified humans may have achieved the status of a guardian kami, but they may only be recognized at certain shrines or in certain households. A prominent example of humans being deified, aside from Japanese emperors, was the shōgun Ieyasu Tokugawa. He, along with his mentors Hideyoshi Toyotomi and Nobunaga Oda, were deified as kami known as gongen after their deaths. ${ }^{180}$ These three men had managed to unify all of Japan and were recognized as exceptional persons. Another example of a person deified who was not a warrior like Tokugawa or his mentors, was Nobumasa Tsugaru (1646-1710 CE). Tsugaru was a daimyō, or feudal lord, who was "praised as a great patron of scholars and artists" and eventually deified as a kami in the Takateru Shrine. ${ }^{181}$

The state and ruling powers did not bother canonizing insignificant things. As mentioned before, natural and manmade objects have been deified. One such object, or rather place, that was discussed earlier was Mt. Fuji. Another object is the sword that belonged to Ieyasu Tokugawa. On one occasion Tokugawa asked that his Miike sword be deified, claiming "this sword must be venerated as a god who [will make] our descendants [endure] for ever and ever."182 The sword is supposedly still kept in Kunō-

\footnotetext{
${ }^{180}$ This was a part of shinbutsu-shūgō which was the syncretism of Shintō and Buddhist practices as they pertained to kami and Buddhas. Tokugawa was given the posthumous name Tōshō Daigongen. See Yoshiro Tamura, Japanese Buddhism: A Cultural history, Tokyo: Kosei Publishing, 2000, 87.

${ }^{181}$ John Breen and Mark Teeuwen, Shintō in History: Ways of the Kami, Honolulu: University of Hawai' $\mathrm{i}$ Press, 2000, 195.

182 John Breen and Mark Teeuwen, Shintō in History, 148.
} 
zan Tōshō-gū Shrine.

A more recent example of deification is that of a cat named Tama in 2015. Kishi Station in Kinokawa, Japan, made Tama, a calico cat, its stationmaster and operating officer. In 2004, the station was experiencing financial issues and was about to shut down. ${ }^{183}$ Tama was then adopted by the station and became stationmaster, increasing passengers for the Kishigawa Line, contributing 1.1 billion yen to Kinokawa's economy. ${ }^{184}$ Tama had saved Kishi station from closing and was beloved by many visitors to Kinokawa. When she died on June 22, 2015, Tama was mourned by thousands and was enshrined at a local Shintō shrine for cats as Tama Daimyōjin, or "Tama, Great Bright Kami,", and given the title "Honorable Eternal Stationmaster."186

There are also other figures in modern Japan that are regarded as kami, yet not considered canonical by others. For instance, there are members of various theatre schools that consider their founders to be kami. They may pray to them for a successful show or production. There are also others, such as Osamu Tezuka, who are recognized as unofficial kami that might be asked for inspiration. Tezuka, still acts as great influence for many mangaka, or comic artists, in their career paths or their stories. In Japan, Tezuka is often referred to as "manga no kamisama," or "God of Manga." ${ }^{187}$ His works are still often highly regarded and he is credited with sparking the popularity of manga and anime in Japan. There are no temples dedicated to him, yet nevertheless his inspiration and

\footnotetext{
183 Justin McCurry, "Tama the Cat: 3,000 Attend Elaborate Funeral for Japan's Feline Stationmaster," The Guardian, 29 Jun 2015, Web, 21 Sep 2017. <https://www.theguardian.com/world/2015/jun/29/tama-thecat-3000-attend-elaborate-funeral-for-japans-feline-stationmaster>

184 Justin McCurry, "Tama the Cat: 3,000 Attend Elaborate Funeral for Japan's Feline Stationmaster."

${ }^{185}$ 大明神 (daimyōjin) is a Shintō title for kami, which originated as a title for kami given by the imperial court, and was later used for deification of important people, such as Hideyoshi Toyotomi.

${ }^{186}$ Justin McCurry, Tama the Cat: 3,000 Attend Elaborate Funeral for Japan's Feline Stationmaster."

${ }^{187}$ See Frederik L. Schodt, The Astro Boy Essays: Osamu Tezuka, Mighty Atom, and the Manga/Anime Revolution, Berkeley: Stone Bridge Press, 2007, 16.
} 
presence is still felt by many who are comic artists or animators. Although Tezuka is not canonized as an official kami, he is clearly recognized as an exceptional contemporary figure who inspires others who pursue his career path. He is an example of a celebrity whose accolades border on devotional.

\section{ATTEMPTS TO CLASSIFY SHINTŌ}

Most religions have denominations or sects, and Shintō is no exception. Japanese religious scholar Dr. Sokyo Ono claims there are several types of Shintō in his concise text, Shintō: The Kami Way. The types of Shintō he categorizes are: 1) Popular Shintō, 2) Domestic Shintō, 3) Sectarian Shintō, 4) Imperial Household Shintō, 5) Shrine Shintō, 6) The Grand Shrine of Ise, and 7) State Shintō. Popular Shintō is described as the "least tangible" form of Shintō in Japan, notable for the importance of kami worship in the lives of its practitioners. Ono argues that the ideas and customs, including those of foreign origin, date back to early Japan and have been preserved due to "unorganized folk ways." He simply explains Domestic Shintō as religious practices in the home at the kamidana, household shrine. Sectarian Shintō dates back to the Meiji period (1868-1912 CE) and relates to groups within the Shintō faith that were connected to the government. Sectarian Shintō emphasized nationalism and support for Shintō as a state cult. Imperial Household Shintō is specific to the Imperial Family, where officials from the Imperial Household perform rites at shrines located within the palace grounds, with the Emperor himself performing the most important rites. Ono claims that Shrine Shintō is the oldest form of Shintō, as well as being the most prevalent form in Japan. He also includes the Grand Shrine of Ise, particularly because of its connection to the sun goddess, Amaterasu, and the subsequent importance of the shrine to the Japanese people and the Imperial Family. 
The shrine itself is considered the tutelary shrine of Japan. Finally, Ono says of State Shintō, "Imperial Household Shintō and Shrine Shintō, along with certain well-defined ideas regarding Japanese origins and history, constituted what was formerly known as 'State Shintō."'188 Of course, this form of Shintō no longer exists after the disestablishment of State Shintō during the U.S. Occupation.

Clearly, Shintō itself has adapted each time political powers shifted in JapanShintō is still present today in the lives Japanese, aside from traditional practices or ceremonial elements. Like the kami, Shintō also seems to be hard to pin down with just one definition as seen when looking at the idiosyncratic definition propagated by Ono or the Shintō that Robert Bella examines. These fluctuations of Shintō have allowed for shifts to take place not only within the religions of Japan, but also within cultural practices and behaviors. Currently, the otaku are incorporating traditional elements of Shintō and applying them to their own devotion of pop culture figures, creating yet another shift in the role of Shintō. To better understand the current role, we must look back towards the categorization of Shintō during the nineteenth century. As Japan entered the Meiji period, the role of Shintō in everyday lives shifted once again, albeit this time it was intentionally broken into specific categories organized by the government.

\section{MEIJI JAPAN}

In the period leading up the Meiji period, from roughly 1633 to $1853 \mathrm{CE}$, Japan was globally isolated and the warrior class became aristocrats. During this period, Buddhism heavily influenced the arts and culture; for instance, flower arrangement and the tea ceremony became recognized as art forms. As the arts flourished and warriors gained social position, most of Japan was at peace. In spite of the peace and flourishing

${ }^{188}$ Sokyo Ono, Shintō: The Kami Way, 15. 
of the arts, the common people were growing unhappy with the Tokugawa shōgunate. Peasants were often heavily taxed by daimyō, samurai could kill a person for any conceived slight, and with the arrival of foreigners demanding that Japan trade with the West, this discontent only grew. In 1853, Admiral Matthew C. Perry arrived in Japan with his steamships on a diplomatic errand for the thirteenth American President, Millard Fillmore. Promising to return, Perry left a letter from the President with Japanese delegates. In 1854, Perry returned with more steamships armed with cannons, forcing the Japanese to open Japan to trade with the outside world under threat of cannon fire.

Previous power shifts had been forced by local Japanese lords vying for power, and the arrival of Perry acted as a catalyst for a new shift focused on the Emperor. This new shift was initiated by the Japanese commoners and those associated with the Imperial Family. Many Japanese were not happy with the way the shōgunate handled the arrival of Perry and his ships. Dissent with the shōgunate had been growing for some time and the opening of Japan was the final straw. The government and Buddhism, which had been under the patronage of the shōgunate, were viewed as corrupt institutions. The populace became unhappy due to over taxation and the immense wealth of Buddhist temples, the major source of tax being the peasantry. ${ }^{189}$ During the Tokugawa period, "[t]he goal of restoring peace, order and prosperity may have been sufficient in the first decades of the period, but it tended to shade into a stagnant conservatism as the decades passed. It is no accident that the movement which finally overthrew the bakufu was characterized by two clear and dynamic goals: restore the emperor and expel the barbarians. ${ }^{, 190}$ Efforts were also made, particularly during the Meiji Restoration

\footnotetext{
${ }^{189}$ Robert N. Bellah, Tokugawa Religion, 22.

${ }^{190}$ Robert N. Bellah, Tokugawa Religion, 22.
} 
(spanning the Meiji period, 1868-1912 CE), to accelerate the modernization and industrialization of Japan in addition to reestablishing Japan as a Shintō-centered state similar to the imagined one prior to the establishment of the shōgunate.

A new form of Shintō developed during the Meiji period, beginning with the restoration of the Emperor as ruler of Japan, which would come to be known as Kokka Shintō, or State Shintō. There were numerous changes in the Meiji period as the new Imperial government moved to modernize Japan, strengthen itself as an economic and military power, and gain equal footing with the Western world. To best understand this period, one should consider Robert Bellah's view and summary of the late Tokugawa period and beginning of the Meiji period:

"[T] money economy, increasing urbanization, an improved communications system, the impoverishment of the samurai class and enrichment of the merchants, the rise of a new artistic and literary culture appropriate to town dwellers rather than courtiers, monks or soldiers, increasing fervor of religious nationalism focusing on the person of the emperor, the propagation of a series of new religious sects, and so on, as indicative of the enormous social and cultural changes going on in the period, many of them directly leading to the Restoration of 1868 and the new Japan that rose thereafter." 191

The changes Bellah mentions also arose in postwar Japan, which will be discussed later in this chapter. Prior to the Meiji period, Shintō had become syncretized with various forms of Buddhism, and in the nineteenth century they were deliberately made distinct by the newly-formed Meiji government. This separation was not exactly peaceful, and many Buddhist temples were destroyed in the process. Shintō also underwent a transformation, changing from Jinja Shintō, or Shrine Shintō, a traditional form of Shintō practiced

${ }^{191}$ Robert N. Bellah, Tokugawa Religion, 11-12. 
before the Meiji period, to State Shintō, thus resulting in a transformation from a traditional folk religion to a state cult. ${ }^{192}$ A popular belief of the Meiji government and populace was that Japan had suffered because they had neglected their rightful duty to the Imperial Family and the kami. State Shintō therefore emphasized the relationship between the kami and the Imperial Family. This new government used the classical texts, the Kojiki and the Nihon Shoki, to propagate and reinforce the idea that the Imperial Family was descended from one of the most important kami, Amaterasu the sun kami. Hence Shintō became a convenient way to legitimate Emperor Meiji's rule and his role in Japan's future.

During this time, State Shintō was institutionalized to both mimic Western countries which were founded and backed by Christian ideologies, and to support and bolster the claim of the Emperor as the true ruler of Japan. The Japanese government was structured in such a manner that foreign dignitaries had no choice except to pay to respects to the Emperor. Thus, the Emperor became a living kami who was to be venerated and who would lead Japan to prosperity. The Meiji period brought dramatic change to the development of technology and the modernization of Japan, aside from the changes to political and societal structures. Meiji means "Enlightened Reign" and Emperor Meiji is considered to have ushered in such an era of enlightenment. ${ }^{193}$ The newly formed Meiji government saw the West, particularly the United States and Europe, as beneficial sources to strengthen and improve Japan. Robert Bellah points out that, "Japan alone of the non-Western nations was able to take over very rapidly what it needed of Western culture in order to transform itself into a modern industrialized

\footnotetext{
192 Jinja Shintō is also the form of Shintō found in Japan today.

${ }^{193}$ The characters “明” and “治” mean “enlightened” and “reign” or “government” respectively.
} 
nation."194 Germany's nationalist movements were particularly influential, as the Meiji government made efforts to unite all Japanese through a common language, race, and religion. ${ }^{195}$ The result was that the entirety of the Meiji period saw Japan flourish as a modern nation state, during which time Japan achieved full modernization on par with Western industrialized countries within mere decades, roughly the 1870 s to the 1880 s. Japan was victorious against larger countries in the Sino-Japanese War (1894-1895 CE) and the Russo-Japanese War (1904), helping Japan to become recognized as a world power with a formidable military force.

\section{WWII AND POSTWAR JAPAN}

The veneration of the Emperor was at the center of State Shintō, and became a fixture in every Japanese citizen's life until the end of World War II in 1945. The powerful sway of State Shintō reached a climax in the 1930s-1940s when Western, particularly American and British, cultural products such as films and music were banned. State Shintō became infused with growing nationalism, and Shintō became a quintessential expression of the Japanese national identity. During this time, nonJapanese religions were repressed or persecuted in favor of proclivities to State Shintō ideals and practices.

Under the care of the government, there were efforts to effectively place Shintō dimensions into the everyday lives of Japanese citizens, such as rote brainwashing of the youth. Every morning students repeated the 1890 Kyoiku ni kansuru Chokugo, or the Imperial Rescript on Education. This ritual repetition of the oath "offer yourselves

\footnotetext{
${ }^{194}$ Robert N. Bellah, Tokugawa Religion, 2.

195 Japan has many dialects of Japanese, as well as the languages of Okinawa and the Ainu. The Meiji government decreed that Kanto, or Tokyo Japanese would be the form of Japanese used for official purposes and documents, as well as in schools.
} 
courageously to the State; and thus guard and maintain the prosperity of Our Imperial Throne coeval with heaven and earth" ${ }^{196}$ was performed every day before school. The education of students was heavily based on a curriculum approved by the state-sanctioned priests. In addition to school and government buildings, as far as local practice included, every household had a kamidana, which can be translated literally as "god-shelf," a mini shrine located within the house. ${ }^{197}$ The newly formed State Shintō affected everyday life well until the end of World War II, and today many households still have kamidana.

Other religions were eradicated in an attempt to purify Shintō temples and shrines of any possible contamination from foreign influence. Many shrines were considered to worship "only the purified, ancient, and imperial kami" that supported the legitimacy of the Emperor. ${ }^{198}$ Shintō shrines became state institutions and "all shrines were subject to the decisions of the appropriate government offices and dependent on them in all important matters relative to personnel, property, rites, and festivals." 199 During the Shōwa period (1926-1989), State Shintō had become organized such that it officially became a government-sanctioned religion, and priests were recognized and employed as government officials.

Prior to the Meiji period, Shrine Shintō had been loosely unorganized, and State Shintō was rigidly organized, affecting every citizen at every level in Japan. Aside from regular shrine worship and festivals, State Shintō included: "commitment to the constitutional pronouncement that the emperor was 'sacred and inviolable'; ethics (shushin) indoctrination in the schools; solemn ceremonial veneration in the schools of

\footnotetext{
${ }^{196}$ Kyoiku ni kansuru Chokugo, Imperial Rescript on Education, October 30, 1890.

197 See Appendix A Figure 2.2.

198 Sarah Thal. "Redefining the Gods: Politics and Survival in the Creation of the Modern Kami," Japanese Journal of Religious Studies 29.3/4 (2002): 395.

${ }^{199}$ Sokyo Ono, Shintō: The Kami Way, 16.
} 
the Imperial Rescript on Education and the imperial portraits; the observance of national holidays." ${ }^{200}$ Enshrined within each kamidana was an image of the Emperor, and every morning prayers and small offerings, such as incense, were offered. Many of these aspects had Shintō dimensions, but were not, as a whole, Shintōist in nature. ${ }^{201}$ Thus, State Shintō was organized in such a way that it could be considered a secular system rather than a religious system.

To again reiterate the influences of power structures in Japanese religion, it should be of note that for a brief time during the Shōwa period, the American government influenced the ideas of what religion was, resulting in removing and dissolving State Shintō. Despite the Japanese government not considering Kokka Shintō to be a religious system, the Allied forces that occupied Japan from 1945-1952 did. After the surrender of Japan in 1945, Emperor Hirohito was made to publicly renounce his divinity and State Shintō was abolished. Under the U.S. Occupation (1945-1952), also known as the Allied Occupation, a constitution similar to the U.S. Constitution was drafted for Japan. The Constitution of Japan contains many of the same articles as its U.S. counterpart, granting the freedom of religion and the separation of church and state. Article 20 of the Constitution of Japan states:

"Freedom of religion is guaranteed to all. No religious organization shall receive any privileges from the State, nor exercise any political authority.

No person shall be compelled to take part in any religious act, celebration, rite or practice.

The State and its organs shall refrain from religious education or any other religious activity.",202

\footnotetext{
${ }^{200}$ Wilbur M. Fridell, “A Fresh Look at State Shintō,” Journal of the American Academy of Religion 44.3 (1976): 551.

${ }^{201}$ Sarah Thal, "Redefining the Gods: Politics and Survival in the Creation of the Modern Kami." 395.

202 The Constitution of Japan. Chapter III, Article 20.
} 
Freedom of religion allowed for numerous new religious movements to grow and removed the prominent influence of Shintō from the government and schools. After WWII State Shintō was no longer the official focus of Japanese life, the Emperor was no longer a living kami to be worshipped and venerated, and public funds were no longer used for Shintō shrines or religious purposes.

The practice of Shintō and maintenance of the shrines moved into private sects, where individuals or families maintained certain shrines at a local level or under the organization of Shintō shrines throughout Japan in what would become known as the Association of Shintō Shrines. The Association of Shintō Shrines formed in 1946 after the Shintō Directive dissolved State Shintō. The Association is made up of 80,000 shrines that are affiliated with the organization. At a national level, the Association oversees the publication of information on Shrine Shintō, performance of rituals, education on Shintō, training for priesthood, and the distribution of amulets, especially those from the Grand Ise Shrine. ${ }^{203}$ These shrines are managed by priests and committees, which are composed of those who represent the worshippers and who may act in a juridical role. The shrines own their land and buildings, and work towards raising funds to support the shrine through private gifts and offerings. ${ }^{204}$ Of course, with the dissolution of State Shintō, the Emperor losing his status as a living kami, and the reprioritizing of Shintō shrines in the lives of the Japanese, a lacuna was left and many new religious groups moved in to fill it.

\section{FORMATION OF NEW RELIGIONS AND NEW-NEW RELIGIONS}

During the Meiji period, new religions were growing despite often being practiced on a small scale, due to the repression of religions and the predominance of State

\footnotetext{
${ }^{203}$ See M.R. Mullins, 'Secularization, Deprivatization and the Reappearance of 'Public Religion' in Japanese Society, Journal of Religion in Japan 1 (2012): 61-82.

${ }^{204}$ Sokyo Ono, Shintō: The Kami Way, 19.
} 
Shintō. ${ }^{205}$ For instance, in 1868, a Meiji government official visited the village of Urakami to discuss the lifting of the Tokugawa ban on Christianity. This official explained that the Meiji government's policy on Christianity reasoned, "that since the Japanese were descendants of the goddess Amaterasu, they ought to worship the emperor, who was the parent-figure, and that it was wrong to embrace a foreign religion, because the true intention of the Catholic priests was to take over Japan." ${ }^{206}$ The Japanese villages of Urakami did not apostatize from Christianity and were punished with exile to different locations throughout Japan, where six hundred died due to torture or poor living conditions. $^{207}$

The shift from pre-war Japan to postwar Japan allowed for growth in religious movements. With the Japanese government no longer banning religions or controlling devotional practices, shinsh $\bar{u} k y \bar{o}$, or new religions, were created. There were religions that arose after the 1970s known as shin-shinshükyō, or new-new religions. Religions which had originally been repressed by the Japanese government grew and flourished in postwar Japan. Robert Kisala and Mark Mullins' introductory chapter in the book Religion and Social Crisis in Japan points out that the "wartime devastation, shock of defeat, and disestablishment of State Shintō, provided a social environment that invited religious alternatives," a reality which came to be known as shinsh $\bar{u} k y \bar{o} .{ }^{208}$ As a result, the suppression of religion from the beginning of the Meiji period and the wake of Japan's defeat in WWII contributed to the eventual emergence of shinshūkyō in postwar

\footnotetext{
205 Joseph M. Kitagawa, Religion in Japanese History, 177-261.

${ }^{206}$ Michiko Yusa, Japanese Religious Traditions, Upper Saddle River: Prentice Hall Inc., 2002, 97.

${ }^{207}$ Michiko Yusa, Japanese Religious Traditions, 97.

${ }^{208}$ Robert Kisala and Mark Mullins, "Introduction," Religion and Social Crisis in Japan: Understanding Japanese Society through the Aum Affair, Eds. Robert Kisala and Mark Mullins. New York: Palgrave, 2001, 2.
} 
Japan.

After WWII Japan, there was another shift, this time in the behavior of the individual Japanese citizen. Whereas individuals were previously expected to contribute to the group and work for the glory of Japan, they could now focus on individual pursuits and interests. Prior to WWII, Japanese religions, mainly Shintō and Buddhism, were affected and regulated by one's family, station in life, and the government. Until the end of WWII, the "importance of the collectivity and of one's particularistic relation to it, [was] indicated by the enormous symbolic importance of the head of the collectivity, whether this be the family head, feudal lord or emperor."209 So one's ties to their group, and the nation itself, was symbolized by one's loyalty to the head of the collective- the Emperor. After WWII, the Japanese had more individual freedom to choose their groups and religion. With the various shinsh $\bar{k} k y \bar{o}$ and shin-shinsh $\bar{u} k y \bar{o}$ that arose, religion was now a matter of individual choice, rather than a practice dictated by one's family or community. Religious salvation, as it had been understood in Buddhism, and devotion were now the prerogative of the individual rather than the traditional community.

Japan's growth after the war saw a boom in a society that had a rising middle class, burgeoning demand for entertainment and material goods, and an increasing demand for living space in the cities. In urban locations, many Japanese were also suddenly feeling isolated and the need for new modes of community support grew. Two religious scholars, Robert Kisala and Mark Mullins claim that: "Lacking the wider network of support once provided by the extended families and rural communities, many individuals found a supportive community in one of the new religions as they struggled

${ }^{209}$ Robert N. Bellah, Tokugawa Religion, 7. 
together to overcome poverty and various forms of illness." 210 These new religions contained religious elements already familiar to the Japanese, coupled with importing ideas from other religions, such as Taoism and various forms of shamanism. The Japanese were now free to choose to practice these new religions without fear of being punished by the government or facing expulsion from their community.

Some prominent shinshūkyō claim to have more than a million followers, at least according to their respective websites and publications, as well as followers in and outside of Japan. The ones that claim to have over millions of adherents are Tenrikyō which was founded in c. 1838, Sōkka Gakkai founded in 1930, and Seichō no Ie founded in c. 1930. In spite of many of these new religions claims of many Japanese followers, not all Japanese view them with enthusiasm. Despite the growth of shinshükyō and shinshinshūkyō, many "religious institutions in Japan in general do not enjoy much trust, with opinion polls indicating that many people feel they are just out to make money or that they play on people's weaknesses to gain new recruits."211 This distrust would eventually be extended to the otaku, particularly due to the leader of the Aum Shinrikyō and their methods of proselytizing which utilized anime and manga.

\section{OTAKU: MARKING THE TRANSISTION FROM THE PROFANE TO THE}

\section{SACRED}

As a capitalist society, it should come as no surprise that the secular or profane has entered into the sacred space of Shintō shrines. The Fushimi Inari Taisha, the head

\footnotetext{
${ }^{210}$ Robert Kisala and Mark Mullins, "Introduction," Religion and Social Crisis in Japan: Understanding Japanese Society through the Aum Affair, Eds. Robert Kisala and Mark Mullins. New York: Palgrave, 2001, 2.

${ }^{211}$ Robert Kisala, "Religious Responses to the "Aum Affair,"” Religion and Social Crisis in Japan: Understanding Japanese Society through the Aum Affair, Eds. Robert Kisala and Mark Mullins, New York: Palgrave, 2001,107.
} 
shrine of Inari, the kami of rice and prosperity, among other things, features torii that bear the names of various Japanese companies. At this particular shrine, Japanese businesses donate money and their donations are reflected in torii of various sizes that line the walkways of the shrine - the larger the donation, the larger the torii. These torii are clearly marked with company names and visitors to the shrine are able to see which companies have donated to the shrine. The shrine itself has been featured in popular culture, except it does not occupy the same links to popular culture as the Washinomiya Shrine and Kanda Shrine. The Washinomiya Shrine in Saitama, utilizes Japanese popular culture to influence visitors to the shrine. The Washinomiya shrine and surrounding town capitalize on the popular anime and manga Lucky $₹$ Star that was influenced by the shrine — encouraging otaku to visit the shrine. The Japan National Tourism Organization encourages visitors to the shrine based on its relation to the anime. ${ }^{212}$ The Kanda Shrine also draws in numerous visitors and is located in the Akihabara district of Tokyo, a popular destination for otaku and fans of popular culture. This particular shrine has capitalized on selling charms associated with business, electronics, and recently naming an anime character from a popular series as its official mascot.

In a modern society such as Japan, it would appear that technology carries with it new connotations of sacred space and community. With the advent of technology and social media, members of various groups can partake in online practices and services online rather than in person. For the otaku, technology enables the creation of an online community, allowing them to share knowledge, experiences, purchase pop products, and to compare their collections. Online they participate in a shared identity and constructed

\footnotetext{
${ }^{212}$ See the Japan National Tourism Organization website, "Lucky Star (Rakiఓ $\zeta$ Suta),” JNTO, n.d. Web. 29 Dec 2015. <http://www.jnto.go.jp/eng/indepth/cultural/pilgrimage/rakisuta.html>
} 
reality. This online community contributes to practices and behaviors shared by those who identify as otaku. Many of these practices and behaviors appear to incorporate religious elements from Shintō, highlighting a possible attempt at reconciling spiritual civilization with material civilization. Some of these practices and behaviors include constructing kamidana-like spaces for their figurines of their pop culture figure or offering food to the figurine on special dates, like the character's birthday. ${ }^{213}$ Upon first glance, pop culture and technology appear to possibly provide a spiritual fulfillment of sorts.

\section{OTAKU AND NEW RELIGIONS}

Whilst there are numerous new religions in Japan, one of the most notorious is the shin-shinshūkyō called Aum Shinrikyō, ${ }^{214}$ a doomsday cult founded in 1984. The Aum Shinrikyō worked to gain power through the use of pop culture in their proselytization of followers. As a result, they influenced views on the use of popular culture, as well as views concerning otaku who consume products of popular culture, such as manga and anime. This group was responsible for the sarin gas attacks on the Tokyo subway system in 1995. These attacks and other controversies connected with the Aum Shinrikyō prompted many Japanese, including the government, to scrutinize not only the Aum Shinrikyō, but also other new religious movements. New religious groups were viewed negatively and consequently many Japanese became hesitant to be public about their religious affiliation or about whether or not they considered themselves to be religious. Many Japanese today regard themselves as 'non-religious' (mūshūkyō). This term “does not mean that they do not believe in anything, but rather it suggests that they do not feel

\footnotetext{
213 This will be examined and detailed further in Chapter Four.

${ }^{214}$ Written オウム真理教, the group’s name translates as “Supreme Truth.”
} 
attached to a specific, historically 'founded religion' that requires personal commitment. ${ }^{215}$ Additionally, the emergence of the Aum Shinrikyō also influenced the negative conceptions associated with the otaku in Japanese society. The Aum Shinrikyō exploited the otaku by using manga to influence followers. Thus, those considered to be "obsessed" with pop culture products were also viewed with suspicion.

Although many Japanese may not feel "religious," some of the Japanese youth growing up during the 1980s felt growing anxieties about their future and as if something was lacking in their lives. During the latter part of the Shōwa period (1926-1989), Japan experienced an immense economic growth known as the Bubble economy (c. 19861991), and many people turned to religion during this time to fulfill their spiritual needs in a materialistic society. As with many economically-developed world powers, the concern in Japan is that during the rise of materialism as a result of affluence, spirituality has declined. Scholars point out that in the case of Japan, "the development of Japanese spiritual civilization (seishin bunmei) has not kept up with the rapid development of the material civilization (busshitsu bunmei). ${ }^{216}$ Arguably, as a result, religious elements have become expressed through growing technology.

Another historical event that affected both the growth of religious groups like the Aum Shinrikyō and the way many Japanese felt about spiritual needs, was the corresponding Bubble Burst in 1991. In 1980s Japan, a Bubble Economy formed due to inflated stock market prices, real estate, and an unchecked expansion of credit and money supply. In the 1980s, Japan was very affluent in terms of economy, which is no wonder

\footnotetext{
${ }^{215}$ Yukio Matsudo, "Back to Invented Tradition: A Nativist Response to a National Crisis," Religion and Social Crisis in Japan: Understanding Japanese Society through the Aum Affair, Eds. Robert Kisala and Mark Mullins, New York: Palgrave, 2001, 171.

${ }^{216}$ Robert Kisala and Mark Mullins, "Introduction,", 15.
} 
that materialism and decadence were prominent. ${ }^{217}$ Two related phenomena concerning Japanese religion were the result of the "bursting" of the Economic Bubble in 1991 and the subsequent recession: As mentioned earlier, numerous opinion polls in Japan indicated that many Japanese viewed new religions negatively, considering them only out to make money. In contrast, new religions were growing because Japanese were, and are, seeking new ways to fulfill spiritual needs.

The Aum Shinrikyō attempted to provide its followers with spiritual fulfillment and appealed to their young followers through pop media. Though the Aum Shinrikyō are not the only new religious movement to use publication to appeal to potential followers, they were unique in the fact that they utilized popular media. One of the reasons for the emergence of the Aum Shinrikyō is thought to be due to "the effects of the information age in general and manga, anime, and computer games in particular. ${ }^{, 18}$ The reason this is significant is because many Japanese youth have the economic means to be avid consumers of the mass media used as teaching tools by the Aum Shinrikyō: "a wide range of media forms (books, magazines, audio tapes, anime [animated films], manga [comic books], radio broadcasts, homepages, etc.) for use in both proselytizing and religious practice. ${ }^{, 219}$ Indeed, Aum Shinrikyō's use of modern technology and media highlights the relationship between religion, mass media, and economic realities in contemporary Japan. Ironically, Aum Shinrikyō was critical of the dangers of mass media and the information age, but utilized both to its advantage in proselytizing new recruits

\footnotetext{
${ }^{217}$ See Christopher Wood, The Bubble Economy: Japan's Extraordinary Speculative Boom of the 80's and the Dramatic Burst of the 90's, New York: Atlantic Monthly Press, 1992.

${ }^{218}$ Richard A. Gardener, "Aum and the Media: Lost in the Cosmos and the Need to Know," Religion and Social Crisis in Japan: Understanding Japanese Society through the Aum Affair, Eds. Robert Kisala and Mark Mullins, New York: Palgrave, 2001, 141.

${ }^{219}$ Richard A. Gardener, "Aum and the Media," 133.
} 
and members.

The synergy between religion and technology is not restricted to the Aum Shinrikyō, as many new religions use mass media, particularly manga, as a teaching tool. Manga has many genres, one of which is the Bukkyo kaisetsu manga, or Buddhism teaching manga. This type of manga is often used to proselytize, or teach Buddhist doctrines, or to spark an interest in Buddhism or Buddhist history. ${ }^{220}$ Over and above the sometime explicit use as a teaching tool, manga and anime contain religious content that include elements of Shintō, Buddhism, and Christianity. For instance, some manga, such as Kannazuki no Miko [Priestesses of the Godless Month] (2004) retell the stories of the sun goddess Amaterasu and the other great kami with modern settings and technology, like the giant robots found in Kannazuki no Miko. Some influential mangaka, or comic artists, craft fictionalized versions of the Buddha's life, such as Buddha (1972) by Osamu Tezuka. ${ }^{221}$ Christian symbols, such as the cross or including Catholic school settings, permeate series involving the supernatural, such as those found in Hellsing (1997) or Shin Seiki Evangerion [Neon Genesis Evangelion] (1995). One could argue that religious traditions in Japan are kept alive through the transmission of manga and anime with their many historical and cultural references to Shintō and Buddhism. Sometimes characters are featured visiting a Shintō shrine to purchase an ema, wooden tablet, to pray for good luck on their math exam. They might purchase an omamori for luck in love or they may be getting ready for the first shrine visit of the New Year, as seen in nearly all manga, especially shōjo manga (girls' manga). Indeed, Jolyon Baraka Thomas's Drawing on

\footnotetext{
${ }^{220}$ See Mark Wheeler MacWilliams, “Japanese Comic Books and Religion,” Japan Pop: Inside the World of Japanese Popular Culture, Ed. Timothy J. Craig, Armonk: M.E. Sharpe, 2000, 109-137.

${ }^{221}$ Tezuka Osamu is considered by many Japanese comic artists and scholars to be the god of manga. See Natsu Onoda Power, God of Comics: Osamu Tezuka and the Creation of Post-World War II Manga, Jackson: University Press of Mississippi, 2009, 1-16.
} 
Tradition: Manga, Anime, and Religion in Contemporary Japan, considers that the media of manga and anime are popular tools that affect the actual transmission of religious traditions.

\section{OTAKU AND POP CULTURE FIGURES}

Similar to the reverence of traditional kami, typical veneration behaviors require a distance between the celebrity kami and the devotee. According to State Shintō and traditional Shintō belief, the Emperor was a living kami descended from with Amaterasu. In postwar Japan, the Emperor is no longer a living kami and is like a celebrity who is still venerated from a distance. When Emperor Shōwa was worshipped in accordance with State Shintō during WWII, many of his officials and others could only talk to him with a screen or a barrier to separate them from the living god they believed him to be. Subsequently, the kamidana located within every household and buildings in Japan, also allowed commoners to be as close as they dared to their Emperor. Objects such as autographs, figurines, music CDs, and so on become objects of veneration that allow the devotee a sort of removed proximity to their pop culture figure.

In contemporary Japan, one can still find a continuity in Shintō ritual practice by the use of the kamidana, or "god shelf," a miniature Shintō altar located in one's home which is dedicated to certain kami. Under State Shintō, the kamidana housed the picture of the Emperor until the U.S. Occupation of Japan, when his image was removed and was replaced with the traditional shintai, or literally the body of a kami. ${ }^{222}$ The shintai is often an item that is representative of the local kami that is enshrined in the household's kamidana for protection. For domestic worship in the household, there are also

${ }^{222}$ Shintai is written as 神体, with the characters for "kami” and "body." 
miniatures of Shintō symbols, such as shimenawa, that are found on the kamidana. ${ }^{223}$ Most commonly, the shintai is a man-made object, such as the mirror that is meant to house and represent Amaterasu, the sun goddess. Similarly, in contemporary Japan the figurines that otaku purchase, share similarities with the traditional shintai because they are man-made and treated reverent manner similar to the Shintō shrine's shintai. The shintai are temporary vessels that the kami inhabit to make themselves accessible to humans. $^{224}$ The figurines of pop culture figures are temporary and a tangible representative of the figure.

Many otaku construct shrine-like spaces in their rooms or living space that resemble kamidana. Unlike the kamidana and shintai, the otaku leave their figurines of their anime pop culture figure on full display. ${ }^{225}$ The area may be decorated with posters, figurines, and other items that are not to be carelessly handled or used. Similar to the idea of distance in the traditional practice, the otaku seem to maintain a respectful distance to the objects representing their pop culture figure. The idea of a removed proximity is again seen when otaku can see the voice actress of their favorite anime character in person. They adhere to an acceptable social distance and at the same time try to be as close as they dare for photo opportunities. These various practices and the idea of the pop culture figure will be discussed at greater length in Chapters 3 and 4.

\footnotetext{
223 Albert Moore, Iconography of Religions: An Introduction, Philadelphia: SCM Press Limited, $1977,183$.

${ }^{224}$ Karen Ann Smyers, The Fox and the Jewel: Shared and Private Meanings in Contemporary Japanese Inari Worship, Honolulu: University of Hawai'i Press, 1999, 44.

${ }^{225}$ The term "pop culture figure," is being used in this dissertation as an umbrella term to refer to a fictional being, such as an anime character, or a human being, such as a pop singer.
} 


\section{THE EMPEROR OF JAPAN: TRANSITION OF THE SACRED TO THE PROFANE}

It is important to note that the Emperor serves as a counterexample to what is happening with the otaku subculture and religion. In this case, his fluctuation of position as a living kami to normal human represents the ambiguity between the boundaries of the sacred and the profane. As the Japanese court was organized and a culture could develop, the Emperor was linked to divine ancestors and he represented the head of the Shintō faith. The association of Shintō with the Imperial Family did not end when the Minamoto clan removed the Emperor from power and established the Kamakura shōgunate (1192$1333 \mathrm{CE}$ ) in 1192, making the shōgun the new leader of Japan. The three shōgunates were the aforementioned Kamakura shōgunate (1192-1333 CE), the Ashikaga shōgunate (1336-1573 CE), and the Tokugawa shōgunate (c. 1600-1868 CE). During the time of the shōgunates, the Emperor was still important, as he was the head priest of the Shintō faith. While the Emperor and the aforementioned shoggunates ruled Japan, it should be noted that Japan itself was not officially united as a country until the Tokugawa shōgunate, which lead to the period known as the Tokugawa period or Edo period (c. 1600-1868 CE). During this time, the Emperor became a mere figurehead as the shōguns ruled Japan from the Kamakura period to the end of Tokugawa period (1192-1868 CE).

From the beginning of the Meiji period in 1868 until the end of WWII, the Emperor was reinstated as the leader of Japan, a living kami who would lead the nation to prosperity. After WWII, when the Emperor was once again removed from a position of power as a living-kami, a new interest took place. Celebrity and pop idols rose in popularity to meet the demand of the rising middle-class of postwar Japan, and would 
become a new way that tradition in Japan would appear to be transmitted, although the traditions are veneration practices rather than narrative details. Arguably, the emergence of modern fan culture and celebrity veneration has potentially replaced the previous reverence of and devotion to the Emperor as a living-kami.

Under State Shintō, the Japanese had been required and sometimes forced to worship the Emperor. With Japan's defeat in WWII, the Emperor was no longer a living god that the Japanese had to worship. The 1959 televised marriage of Crown Prince Akihito to the wealthy commoner Michiko Shoda illustrated a new place in emperor worship. ${ }^{226}$ Though the Emperor was no longer worshipped as a living god, his family members became revered as celebrities. ${ }^{227}$ This sudden cultural shift from state cult of the Emperor, along with removal of state control of religious practices arguably left a lacuna in Japanese devotional practices. In 1959, the creation of national commercial television networks and the rise of private ownership of television sets grew as a result of the marriage of the Crown Prince to a commoner. People crowded them in public appearances for autographs and young people looked to Crown Prince Akihito and Michiko as fashion icons, not unlike the contemporary phenomenon with British royals, Prince William and Kate. Thus, historically the Emperor's family has moved from being inherently divine to being charismatic public individuals. ${ }^{228}$

The shift of the Imperial Family from divine beings to celebrities was also in part due to the efforts of the Kunaicho, or the Imperial Household Agency. By using mass media as a means to improve relations with the Japanese populace, mass media was able

\footnotetext{
${ }^{226}$ Jayson Chun, “A New Kind of Royalty: The Imperial Family and the Media in Postwar Japan,” Japan Pop: Inside the World of Japanese Popular Culture, Ed. Timothy J. Craig, Armonk: M.E. Sharpe, 2000, 222-223.

227 Jayson Chun, “A New Kind of Royalty," 223.

${ }^{228}$ Charisma will be discussed further in Chapters 3 and 4.
} 
to use the Imperial Family to garner viewers and promote the sale of televisions. ${ }^{229}$ As a result, the media outlets in early postwar Japan focused on entertainment and information rather than using television as a means of just providing announcements from the government or showing propaganda. The energy for devotion could be placed elsewhere, and rather than focusing devotion on the Emperor, fan cultures emerged where devotional energy could be given to Japanese baseball teams, singers and music groups, comic books, and so on.

To summarize, the energy for devotion turned the Imperial Family into celebrities in 1959 in part due to the Imperial Wedding. Despite the Imperial Family becoming celebrities, the devotion of Japanese fans to celebrities was nothing new. Many Japanese adored Kabuki actors in the seventeenth century, and traditionally, Zen Buddhist masters would have devoted groups of followers, but this new devotional energy in post-war Japan was different. ${ }^{230}$ The evolution from the Emperor's position as a living god to a celebrity created a paradigm/model for other media figures to be venerated as celebrities in a similar fashion. Arguably, the celebrities occupy a seemingly similar place in reverence and devotion as the kami did in traditional Shintō. Unlike the traditional kami, these celebrities could not offer blessings or perform any of the other acts of power that kami traditionally possess.

\section{CONCLUSION}

Shintō shrines were also affected by the fluctuations of power in Japan, such as those during WWII Japan. Shintō shrines the Emperor visited prior to WWII were lavish and only benefitted from the patronage of the Imperial Family. During WWII, under

\footnotetext{
${ }^{229}$ Jayson Chun, "A New Kind of Royalty," 226.

${ }^{230}$ See Fanning the Flames: Fans and Consumer Culture in Contemporary Culture, Ed. William W. Kelly, New York: SUNY Press, 2012, 62, 95, 132, 133.
} 
State Shintō many shrines were owned by and associated with the government. After the Shintō Directive, an order from the U.S. Occupation forces to the Japanese government, Shintō shrines and priests were no longer supported by public funds. ${ }^{231}$ Additionally, the Emperor could no longer worship as a living-kami speaking to his ancestors, but rather as an individual who was worshipping in a non-official capacity. Contemporary shrines maintain their grounds and upkeep of the shrine by acclimating to and anticipating the spiritual needs of modern Japan — for instance, selling ema and omamori for luck on school tests, to pass a driver's test, or to have a priest bless a new vehicle.

Unsurprisingly, Shintō manages to remain relevant for contemporary Japanese. It does so by addressing the concerns and anxieties that many Japanese youth, the otaku included, have about the future. Some of the anxieties and fears that otaku have are rooted in the fact that many Japanese businesses no longer offer lifetime employment, as well as the fact that Japan has been in a recession since the "Bubble" burst in 1991, and that there are many shifting trends in public and private life. While visits to Shintō shrines or Buddhist temples to pray or wish for help from divine spirits may not always alleviate all fears and anxiety, mass media can by providing an ephemeral escape from reality. But in a country such as Japan, where religion permeates and is deeply ingrained in the culture, it should come as no surprise that religion is also present in the mass media. As Robert N. Bellah points out: "The chief social functions of religion as we see them are to supply a context of meaning for the central values of society and to meet the threats to these values posed by the ultimate frustrations of the human situation."232 This

\footnotetext{
${ }^{231}$ From 1946 to 1952, Allied Forces occupied Japan, serving as de facto ruler of Japan during this time. See Susumu Shimazono, "State Shintō and Religion in Post-War Japan," The Sage Handbook of the Sociology of Religion, Thousand Oaks: Sage Publications, 2007, 697-709.

${ }^{232}$ Robert N. Bellah, Tokugawa Religion, 53.
} 
function is reformed by both religion and the mass media in Japan. Along a similar note concerning the frustrations and problems of being human, Weber states, "the development of the 'capitalist spirit' can most easily be understood as a part of the total development of rationalism and must be derived from the latter's fundamental attitude to the ultimate problems of life. ${ }^{, 233}$ In his discussions of rationalism, Weber argues that rationalism is a result of the capitalist spirit and that rationalism is "that conduct of life which deliberately relates the world to the secular interests of the individual and judges from that perspective. ${ }^{.234}$ Although a product of capitalism, mass media is a secular interest, one that is tinged with a myriad of religious meaning through symbols, storylines, and location.

As seen in this review of religious history, religious practices, and the relationship of religion to society, religious power and ideas of the sacred and profane have shifted many times. Most notably, these shifts have changed the main locus of what is considered "sacred," such as the roles of leadership and the influence of social, political, and economic relations. At one point, one could argue that the Emperor or the political powers that were in charge served as a catalyst for the role of religion in the lives of the Japanese people. In modern Japan, one group of people, the otaku, have begun to act as a catalyst that conflate visual media, particularly anime and manga, and religion in a disposable consumer society. These anime and manga figures become kami-like figures that are regarded with devotional-like behaviors and practices. There is also a growing impact outside of the otaku, an unintended consequence, that is seeing anime and manga becoming linked to Japanese religious sites, as seen with the more mainstream anime,

\footnotetext{
${ }^{233}$ Max Weber, The Protestant Ethic, 27.

${ }^{234}$ Max Weber, The Protestant Ethic, 27.
} 
Ano Hi Mita Hana no Namae o Bokutachi wa Mada Shiranai (Anohana: The Flower We Saw That Day) (2011) and the Chichibu Shrine and the Jōrin-ji Temple. ${ }^{235}$

These shifts have parallels to Weber's examination of Protestantism and capitalism. Robert N. Bellah also saw similarities to Weber, saying, "Max Weber's great work on the relation of religion to the development of modern Western society, especially the modern economy, naturally wonders whether religious factors might be involved in the Japanese case. ${ }^{, 236}$ Like Protestantism in the West, Shintō in Japan has been reformulated through a secular society, tied in to economy, as well as affecting ideas of community, and notably applying religious ideas and practices to a secular society deeply rooted in tradition. One element that has remained present, although its importance has varied, is a devotion to the kami or kami-like figures. The importance of the kami has shifted throughout the development of Japan, from clan deities to living gods to today's celebrity and pop culture figures. Devotional practices have appeared to transition as well, shifting from devotion to those in power to characters from mass media. Ultimately these celebrity and pop culture figures are not being worshipped in a completely religious-like manner similar to the kami that provide good harvests, and instead may fulfill a need for devotion and possibly love in a postmodern capitalist society.

\footnotetext{
${ }^{235}$ This anime will be discussed further in Chapter Four.

${ }^{236}$ Robert N. Bellah, Tokugawa Religion, 2.
} 


\section{CHAPTER THREE: UNDERSTANDING THE OTAKU MIND: OTAKU HISTORY}

\section{AND IDENTITY}

Most Japanese pop culture, particularly anime and manga, are widely enjoyed throughout Japan despite most pop culture being marketed towards otaku. This marketing towards otaku points to their role as a sort of barometer for measuring consumer trends in pop culture and electronic products. ${ }^{237}$ By understanding the behavior and identity of otaku, this dissertation will be closer to showing how their behaviors and consumption of Japanese popular culture have begun to highlight a melding of secular and religious practices. This chapter will examine the psychological mindset and social construction of the Japanese otaku identity, particularly focusing on otaku interested in anime and manga. This will be followed by a closer examination of specific practices and behaviors of the otaku in Chapter Four. This dissertation argues that parts of contemporary Japanese popular culture are blended with Japanese religious elements that are incorporated through the otaku's consumption of popular culture, particularly popular culture that is related to anime and manga. ${ }^{238}$

The otaku are adapting certain elements of religious traditions to the subculture at their disposal, unconsciously passing down religious traditions through the pop culture

\footnotetext{
${ }^{237}$ See Satoru Kikuchi, "The Transformation and Diffusion of 'Otaku' Stereotypes and the Establishment of 'Akihabara' as a Place Brand," Debating Otaku in Contemporary Japan: Historical Perspectives and New Horizons, Eds. Patrick W. Galbraith, Thiam Huat Kam, and Björn-Ole Kamm, London: Bloomsbury Academic, 2015, 152-153.

${ }^{238}$ This dissertation uses the terms "pop culture" and "popular culture" interchangeably. For the purposes of this dissertation, pop culture/popular culture only refers to anime and manga unless otherwise specified.
} 
products themselves. Despite religious elements are being incorporated into behaviors and practices, such as the wooden prayer tablets that feature anime characters, it should be noted that they are not replacing any established religions or canonical deities from Japanese religious traditions.

This chapter, and Chapter Four, will focus on the use of the Internet as a tool for communication and sharing of knowledge between the otaku, as well as the Internet as a virtual space allowing the formation of their identity. The Internet's significance lies in its role in the formation of the otaku identity, which unites and provides the otaku a community that only continues to grow due to the increasing accessibility of the Internet and social media. The otaku existed before the use of Internet message boards and social media, but in small pockets linked only through magazine columns and conventions. To understand how the otaku evolved into their current subculture, this chapter will provide a definition of the "otaku" through a historical background, to provide a foundation of who the otaku are and why they are so influential in marketing Japanese pop products. ${ }^{239}$

\section{ETYMOLOGY AND HISTORY OF THE WORD “OTAKU”}

As Japanese pop culture flourished throughout the 1980s, fans of anime, manga, and video games appropriated the term "otaku" to use as a way to identify themselves to one another, as would those who would eventually use the term to mock them. Otaku initially used the term to refer to one another, being the first to adopt the use of the word when interacting with one another. Traditionally, otaku was a term derived from "an

\footnotetext{
${ }^{239}$ Additionally, there are female fans sometimes known as fujoshi, but they do not share the same practices or behaviors as the male otaku and are beyond the scope and goal of this dissertation. Fujoshi often translates to "rotten girl." For more information on female fans of manga and anime, see Patrick W. Galbraith, "Fujoshi: Fantasy Please and Transgressive Intimacy among 'Rotten Girls' in Contemporary Japan," Signs 37.1 (2011): 211-232. Also see, Matthew Thorn, "Girls and Women Getting Out of Hand: The Pleasure and Politics of Japan's Amateur Comics Community," Fanning the Flames: Fans and Consumer Culture in Culture in Contemporary Japan, Ed. William W. Kelly, Albany: State University of New York Press, 2004, 169-188.
} 
honorific meaning 'your' or 'your house,' [and] the Japanese word otaku was appropriated in the 1980s to refer to obsessive fans, particularly those attracted to manga, anime, and videogames," not to mention because of the amount of time the otaku spent at home. $^{240}$

According to Toshio Okada, the term originated with Keio University graduates in 1982, and he states the commonly accepted opinion "is that the rich kids who graduated from Keio University were the first to use the term 'otaku.",241 Okada goes on to explain that because "they called one another otaku in front of fans at science fiction conventions, it is impossible that other otaku did not imitate them."242 Thus, many scholars accept that the word was indeed used as an identifier to help categorize one another as fans of science fiction anime. Afterwards, that term came to be used by many others to describe themselves as a fan of something.

Another word that had been used to describe fans of particular pop culture items was mania, which means "maniac," and referred to "someone who is very enthusiastic about a given topic; though it referred to the habit of collecting, it did not have negative connotations beyond 'know-it-all.", 243 The connotations of otaku is often associated with fans who are engrossed in their hobby to the point of unhealthy obsession. Selfproclaimed "King of the Otaku" and otaku apologist, Toshio Okada explains the difference between otaku and mania as relating to their social acceptability. Mania are

\footnotetext{
${ }^{240}$ Lien Fan Shen, "Traversing Otaku Fantasy: Representation of the Otaku Subject, Gaze and Fantasy in Otaku no Video," Debating Otaku in Contemporary Japan: Historical Perspectives and New Horizons, Eds. Patrick W. Galbraith, Thiam Huat Kam, and Björn-Ole Kamm, London: Bloomsbury Academic, 2015, 73.

${ }^{241}$ Qtd in Miho Aida, "The Construction of Discourses on Otaku: The History of Subcultures from 1983 to 2005," Debating Otaku in Contemporary Japan: Historical Perspectives and New Horizons, Eds. Patrick W. Galbraith, Thiam Huat Kam, and Björn-Ole Kamm, London: Bloomsbury Academic, 2015, 118.

${ }^{242}$ Qtd in Miho Aida, "The Construction of Discourses on Otaku: The History of Subcultures from 1983 to 2005," 118-119.

${ }^{243}$ Björn-Ole Kamm, “Opening the Black Box of the 1989 Otaku Discourse," 58.
} 
those who have socially accepted hobbies and who have "normal" or tolerable fan behaviors. He claims, "It's just a matter of societal labeling (retteru o hatteiru dake no mondai). That's the only difference between mania and otaku." ${ }^{, 244}$ However, the issue of what to call these fans of anime and manga, is credited with originating in a niche magazine called Manga Burikko in 1983. Author Akio Nakamori's description of the otaku in a column entitled "'Otaku' Research: The City is Full of 'Otaku,"” has persisted as the stereotype of otaku today. His description of the otaku touched on their fashion sense and physical appearance, as follows:

"Their hairstyle is either rumpled long hair clearly parted $7: 3$ at the front, or a dowdy, close bowl cut. They tottered back and forth, smartly clad in shirts and slacks their mommy bought at the 'all ¥980/1980 rack at Itō Yōkado or Seiyū, their feet shod in 'R'-branded knock-offs of Regal sneakers that were popular several years ago, shoulder bags bulging and sagging. The boys are either skin and bonesborderline malnourished-or squealing pale-faced piggies (warau shirobuta) with chubby faces so fat that the arms of their silver-plated glasses dug into the sides of their brow. All the girls sported bobbed hair and were mostly fat, having tubby legs like tree-logs covered in white highsocks." 245

This description, coupled with two more installments of his "research" led to the editor, Eiji Ōtsuka, arguing that the way in which Nakamori was using "otaku” was

discriminatory. The otaku became associated with something akin to social outcast and reject.

\section{HISTORICAL OVERVIEW OF THE OTAKU}

"Otaku" had originally only been used among those who were otaku or who were

\footnotetext{
${ }^{244}$ Qtd in Patrick W. Galbraith, Thiam Huat Kam, and Björn-Ole Kamm, 'Introduction: 'Otaku' Research: Past, Present and Future,’ Debating Otaku in Contemporary Japan: Historical Perspectives and New Horizons, Eds. Patrick W. Galbraith, Thiam Huat Kam, and Björn-Ole Kamm, London: Bloomsbury Academic, 2015, 11.

${ }^{245}$ Akio Nakamori, “'Otaku' Research: The City is Full of 'Otaku,”” Manga Burikko June 1983: 200-201.
} 
familiar with the growing fan culture in the late 1970s and early 1980s. The word "otaku" has fluctuated as a word referring to fans of sci-fi anime to an insult with negative connotations, akin to calling someone a geek or nerd. It has been used as a way to identify a particular group, discriminate and denigrate others, at the same time, according to some, it has become partially redeemed through popular media that focuses on the otaku, such as the multimedia success of Densha Otoko [Train Man]. ${ }^{246}$ According to Eiji Ōtsuka, a Japanese critic and scholar, the subculture that came to be known as otaku began with the student and leftist movements of the 1960s. Interestingly enough, Ōtsuka "sees no value in discussing otaku in the academy" and that it is essentially a joke, yet he goes into great detail to explain the origins of otaku and their place within Japanese society. ${ }^{247} \mathrm{He}$ was 'the editor of Manga Burikko, where the term ['otaku'] was first used to describe uncool fan cultures in 1983, his insistence that 'otaku' were being demonized in the media ultimately served to spread the word to the wider public."248

Many scholars and critics, such as Toshio Okada ${ }^{249}$ and Hiroki Azuma, ${ }^{250}$ have theorized the origins of otaku culture. Despite Ōtsuka's insistence that the subject is not worth examining, he has traced the origins back to the 1970s, providing a comprehensive outline of the historical and cultural contexts that led to the creation of the otaku. The origins of the otaku, according to Ōtsuka, was comprised of the former "losers" of one

\footnotetext{
${ }^{246}$ Densha Otoko was supposedly the true story of an otaku who met and fell in love with a career woman. The story began as a series of posts on Internet message forum, 2Channel, where the otaku asked the other members advice on how to date the woman. It was compiled and released as a novel in 2004, several manga versions in 2006, as well as a film and television drama series in 2006.

${ }^{247}$ Eiji Ōtsuka, "Otaku Culture as 'Conversion Literature,"” xiii.

${ }^{248}$ Eiji Ōtsuka, "Otaku Culture as 'Conversion Literature,"” xiii.

${ }^{249}$ See Toshio Okada, "Introduction to Otakuology," Debating Otaku in Contemporary Japan: Historical Perspectives and New Horizons, Eds. Patrick W. Galbraith, Thiam Huat Kam, and Björn-Ole Kamm, London: Bloomsbury Academic, 2015, 89-101. See also Toshio Okada "The Transition of Otaku and Otaku," Debating Otaku in Contemporary Japan: Historical Perspectives and New Horizons. Eds. Patrick W. Galbraith, Thiam Huat Kam, and Björn-Ole Kamm, London: Bloomsbury Academic, 2015, 163-177.

${ }^{250}$ See Hiroki Azuma, Otaku: Japan's Database Animals, Trans. Jonathan E. Abel and Shion Kono, Minneapolis: University of Minnesota Press, 2009.
} 
particular student movement, the Zenkyōtō movement, ${ }^{251}$ who then went on to become "leaders of children's culture and subculture from the 1970s onwards." 252 To fully grasp how the otaku came into being, two of Ōtsuka's ideas are most significant. He claims subculture was given two contexts:

"the first is the marketing context. Taking as its object the capitalist system, this is the attitude of evaluating everything as a commodity and the masses as consumers who can be manipulated. [...] [Thus,] the ideology of 'otaku' culture in Japan since the 1980s is 'marketing.' [...] The second context, however, even though it is in collusion with capitalism, coexists with a mentality that still evaluates subculture as 'counter to the establishment' (taisei e no kauntā). These two ways of thinking were claimed as the fundamental frameworks of criticism by the first generation of 'otaku.",253

Ōtsuka is critical and suspicious of studying the otaku, although conversely he has spoken often of them, and considers himself both an otaku and an expert on the otaku. He provides a coherent explanation of how the so-called "losers" of the student movements of the 1970 s came to have cultural influence and form the subculture that would one day be identified as "otaku." Ōtsuka claims:

"University students had replaced the working class as the mainstream consumers of Japanese popular culture. [...] Amid the backdrop of university students - who should be the bearers of 'cultivation' (kyoyyo) - transforming into simply consumers of culture (bunka no shōhisa), subculture changed into the consumer culture of the 'middle class' (chūkansō no shōhi bunka), not popular culture as the culture of the working class (rōdo kaikyū no bunka toshite no taishu bunka). [...] Next, the generation born around 1960 (in other words, the first generation of otaku), which

\footnotetext{
${ }^{251}$ The Zenkyōtō movement was a leftist movement in Japan during the late 1960s in which college students challenged ideologies and power structures of the university system in Japan, as well as the supposed development of Japan, economically and so on. See Patricia G. Steinhoff, "Japan: Student Activism in an Emerging Democracy," Student Activism in Asia: Between Protest and Powerlessness, Eds. Meredith Leigh Weiss and Edward Aspinall, Minneapolis: University of Minnesota Press, 2012, 57-78.

${ }^{252}$ Eiji Ōtsuka, "Otaku Culture as 'Conversion Literature,", xvii.

${ }^{253}$ Eiji Ôtsuka, "Otaku Culture as 'Conversion Literature,"” xvii-xviii.
} 
refused to let go of manga and anime as 'children's culture,' birthed a situation where a new market could be realized." 254

Thus, according to Ōtsuka, the otaku are essentially rooted in a capitalist middle-class and became the primary consumers of Japanese popular culture. This first generation of otaku are the ones who created a new market that was and still is heavily influenced by the otaku themselves. According to Ōtsuka's timeline, otaku and otaku culture are slightly more than 40 years old, meaning that this is still a relatively young subculture.

The interesting paradox is that the otaku are the ones who would go on to work in media and were the largest consumers of pop media with the "otaku market" being worth 410 billion yen (roughly 3.6 billion U.S. dollars) in 2005, yet they are still regarded with suspicion by the rest of Japan. ${ }^{255}$ Anime itself reaches an estimated 87 percent of the world's population $^{256}$ and manga constitutes over 20 percent of the Japanese publishing industry. ${ }^{257}$ When compared to the U.S. comic market, which is only worth $\$ 800$ million compared to Japan's $\$ 3.6$ billion, ${ }^{258}$ and considering the fact that 40 percent of animation in the U.S. is Japanese anime or anime inspired, it is clear that Japanese pop culture has popularity in the U.S. ${ }^{259}$ That does not take into account the popularity of Japanese works

\footnotetext{
${ }^{254}$ Eiji Ōtsuka, "Otaku Culture as 'Conversion Literature,"” xviii-xix.

${ }^{255}$ See Satoru Kikuchi, "The Transformation and Diffusion of 'Otaku' Stereotypes and the Establishment of 'Akihabara' as a Place Brand," Debating Otaku in Contemporary Japan: Historical Perspectives and New Horizons, Eds. Patrick W. Galbraith, Thiam Huat Kam, and Björn-Ole Kamm, London: Bloomsbury Academic, 2015, 152.

${ }^{256}$ Kazuaki Nagata, “'Anime’ Makes Japan Superpower: Culture Extended from Manga Finds EverIncreasing Global Fans,” Japan Times, 7 Sep 2010, Web, 14 Sep 2017, $<$ https://www.japantimes.co.jp/news/2010/09/07/reference/anime-makes-japansuperpower/\#.WbvnPNOGORs>

${ }^{257}$ Susan Napier, "Manga and Anime: Entertainment, Big Business, and Art in Japan," Routledge Handbook of Japanese Culture and Society, Eds. Victoria Lyon Bestor, Theodore C. Bestor, and Akiko Yamagata, New York: Routledge, 2011, 228.

258 Tom DiChristopher, "Three Publishers Changing the Comic Book Industry," CNBC, 25 Jan 2016, Web, 14 Sep 2017, <https://www.cnbc.com/2016/01/24/comic-book-publishers-thrive-in-the-industry.html>

${ }^{259}$ Michael R. Czinkota and Ilkka A. Ronkainen, International Marketing, Mason: Thomas Higher Education, 2007, 291.
} 
that are illegally translated and downloaded by people outside of Japan. The Japanese government has noted the influence and impact of the otaku, thus capitalizing on the subculture and promoting it as "Cool Japan" which will be discussed further later in this chapter.

The otaku impact and influence a large portion of Japanese pop culture, especially with regard to anime and manga. In spite of being influential, the otaku and the word itself have not been highly regarded. The word "otaku" began to take on negative connotations through a series of events in which the otaku were associated with a serial killer, religious cults, and being failed men. Although there have been attempts to "reintegrate" the otaku into Japanese society, as seen with the popularity of Train Man, the term 'otaku' and otaku themselves still face some adversity. ${ }^{260}$ For instance, on December $31^{\text {st }}$, 2013, a young man purposely went to Akihabara to beat up otaku and take their money. His reasoning was, "Since Akihabara is filled with otaku, I didn't think there'd be anyone who could really handle himself in a fight." ${ }^{261}$

\section{UNDERSTANDING AND PERCEPTIONS OF THE OTAKU}

As noted earlier, the earliest sense of the word, "otaku" meant "you" or "your house or home" and was a polite second-person pronoun. The Japanese dictionary Köjien defines otaku as, "People who are interested in a particular genre or object, are extraordinarily knowledgeable about it, but are lacking in social common sense [shakai teki na jōshiki]."262 Some scholars assert that the term was used by some Japanese to

\footnotetext{
${ }^{260}$ Many scholars, such as Alisa Freedman and Thiam Huat Kam, analyze the success and impact of Densha Otoko (Train Man), a supposedly true story posted on 2channel in 2004. See in general Debating Otaku in Contemporary Japan: Historical Perspectives and New Horizons, Eds. Patrick W. Galbraith, Thiam Huat Kam, and Björn-Ole Kamm, London: Bloomsbury Academic, 2015.

${ }^{261}$ Casey Baseel, "Man Arrested for Hunting the Nerdiest Game: Akihabara Otaku," Rocket News, 13 May 2014, Web, 25 Mar, 2016.

${ }^{262}$ Quoted in Thiam Huat Kam, “The Common Sense that Makes the 'Otaku': Rules for Consuming
} 
show how "the name of the group demonstrates the alienation of its members from other groups, their desire to politely keep their distance from both the dominant culture and from the people in their own group." 263 Thus, the separatist identity of the "otaku" becomes an identifier that sets them apart from normative society, or non-otaku. Many Japanese read and watch anime, and commonly consume the products, but they are not identified as “otaku." Mizuko Ito points out, "In Japan, much of manga and anime is associated with mainstream consumption; otaku must therefore differentiate themselves from ippanjin (regular people) through a proliferating set of niche genres, alternative readings, and derivative works. ${ }^{264}$

The term "otaku" as a designation of group identity has many negative connotations. One particular event that changed public opinion about the otaku was the arrest and trial of serial killer Tsutomu Miyazaki in 1989. The media coverage resulted in the word "otaku" becoming associated with a more sinister image of obsessive fans that were unpredictable. ${ }^{265}$ Prior to the arrest and trial of Miyazaki, the word otaku was not used in the mainstream media. ${ }^{266} \mathrm{He}$ was arrested for the mutilation and murder of four young girls, aged four to seven. The media supposedly labeled Miyazaki as an "otaku." In Björn-Ole Kamm's "Opening the Black Box of the 1989 Otaku Discourse," Kamm examined newspapers and databases to find out how the term "otaku" was transferred

\footnotetext{
Popular Culture in Contemporary Japan,” Japan Forum 25.2 (2013): 152.

${ }^{263}$ Quoted in Maya Keliyan, "Kogyaru and Otaku: Youth Subcultures Lifestyles in Postmodern Japan," Asian and African Studies 15.3 (2011): 103.

${ }^{264}$ Mizuko Ito, "Introduction," Fandom Unbound: Otaku Culture in a Connected World, Eds. Mizuko Ito, Daisuke Okabe, and Izumi Tsuji, New Haven: Yale University Press, 2012, xvii.

${ }^{265}$ See Björn-Ole Kamm, “Opening the Black Box of the 1989 Otaku Discourse,” Debating Otaku in Contemporary Japan: Historical Perspectives and New Horizons, Eds. Patrick W. Galbraith, Thiam Huat Kam, and Björn-Ole Kamm, London: Bloomsbury Academic, 2015, 51-70. See also William W. Kelly, "Introduction: Locating the Fans," Fanning the Flames: Fans and Consumer Culture in Culture in Contemporary Japan, Ed. William W. Kelly, Albany: State University of New York Press, 2004, 1-16. ${ }^{266}$ See Björn-Ole Kamm, “Opening the Black Box of the 1989 Otaku Discourse,”, 51-70.
} 
from a small niche-market magazine to the mass media. ${ }^{267}$ In his research, Kamm finds that the first instance of using "otaku" with its negative connotations, as well as the word "otaku" itself, in the mass media was when Eiji Ōtsuka's article in a special-interest newspaper attempted "to defend video collectors against a witch-hunt that [Ōtsuka] believed to be unfolding" in the wake of Miyazaki's arrest. ${ }^{268}$ Kamm concludes that:

"While journalists and jurists debated the links between the crimes and the media found in Miyazaki's room, manga and anime critics and producers, those who know better, gave them the key term for this controversy: before Ōtsuka used otaku in his discussion of Miyazaki and the wrong impression of otaku, or Takatori mused about Miyazaki and the otaku-zoku, no mainstream journalists had used the term in this way. Ōtsuka and others are the ones that made the connection. $\$ 269$

The word otaku did not become a negative term recognized by the mainstream until otaku began attempting to assert that Miyazaki was nothing like them during his trial in $1990 . .^{270}$

Despite the fact that the mainstream media had not used the word otaku and the negative connotations associated with it, the rest of Japan began to see the otaku as potential deviants. William W. Kelly explains the resulting negative associations with the term "otaku" after Miyazaki had been arrested:

"Miyazaki was labelled an otaku, the term that had been adopted within manga fans and amateur artists to identify the weirdos $[$ sic $]$ among them but which had been less dysfunctional and sometimes even endearing connotations in other fandoms. [...] Otaku [are] nerds and geeks and loners, [who] perhaps orbit more 'into' something than

\footnotetext{
${ }^{267}$ Björn-Ole Kamm, "Opening the Black Box of the 1989 Otaku Discourse," 51-70.

${ }^{268}$ Björn-Ole Kamm, "Opening the Black Box of the 1989 Otaku Discourse," 58.

${ }^{269}$ Björn-Ole Kamm, "Opening the Black Box of the 1989 Otaku Discourse," 64-65.

${ }^{270}$ See Björn-Ole Kamm, "Opening the Black Box of the 1989 Otaku Discourse," Otaku in Contemporary Japan: Historical Perspectives and New Horizons, Eds. Patrick W. Galbraith, Thiam Huat Kam, and BjörnOle Kamm, London: Bloomsbury Academic, 2015, 51-70.
} 
other fans, but not necessarily psychologically unstable and criminally inclined. The Miyazaki arrest changed the public use of the term [otaku]." ${ }^{, 71}$

After he had been arrested, pictures of him and his apartment were all over the media, embracing a negative image. According to Mark Driscoll, the Japanese news media:

"reported that Miyazaki's lifestyle was that of an otaku par
excellence; images of his apartment were constantly shown
on Japanese television exposing his collection of girl's
manga, Lolita-complex (Ro-ri con) animations, and a huge
collection of softcore porn magazines. He was also
unveiled as an avid participant in several subcultural
dôjinshi-fanzine groups that exchange information and
erotic fantasies about animation characters."

The negative media attention and "severe bashing in the press in the wake of the Miyazaki incident incited a reverse reaction from the otaku themselves, who have now become hyperconscious of their identity as otaku." ${ }^{, 273}$ Akin to many Japanese refusing to label themselves as "religious" after WWII Japan's enforcement of State Shintō and the Aum Shinrikyo affair, many otaku hesitate to identify themselves as such unless in the presence of other otaku. ${ }^{274}$ They are always aware of their identity and society's conception of otaku.

There are other scholars, however, such as Alisa Freedman, who argue that otaku have become less stigmatized as of 2004 due to the publication of Densha-Otoko [Train Man], a love story about an otaku who used the Internet forum $2 \mathrm{ch}$ (channel 2) to get

\footnotetext{
${ }^{271}$ William W. Kelly, "Introduction: Locating the Fans," 12.

${ }^{272}$ Mark Driscoll, "Debt and Denunciation in Post-Bubble Japan: On the Two Freeters," Cultural Critique 65 (2007): 171.

${ }^{273}$ Hiroki Azuma, Otaku: Japan's Database Animals, Trans. Jonathan E. Abel and Shion Kono, Minneapolis: University of Minnesota Press, 2009, 4.

${ }^{274}$ Yukio Matsudo, "Back to Invented Tradition: A Nativist Response to a National Crisis," Religion and Social Crisis in Japan: Understanding Japanese Society through the Aum Affair, Eds. Robert Kisala and Mark Mullins, New York: Palgrave, 2001, 171.
} 
advice on dating a girl who was a non-otaku. ${ }^{275}$ The publication was so popular that it led to a television drama of the same name in 2005. Mizuko Ito claims that the popularity of Densha-Otoko was "a crucial turning point: by representing otaku as harmless and endearing, both dramas helped to remove the subculture's historically more negative and sociopathic connotations and to recast it in a much more sympathetic light." ${ }^{276}$ Alisa Freedman argues:

"along with changing the form of books and furthering cross-media promotion, the protagonist of Train Man has encouraged more discussions about social expectations for Japanese men in the mass media during the time of falling marriage and birthrates than any other real personage or fictional character [...] In articles in news magazines devoted to issues of marriage and family and the concurrent spate of books about heterosexual relationships, Train Man has been described as a potential marriage partner for career women, a demographic blamed for marrying late."277

Train Man, according to Freedman, helped change the perception of the otaku and potential marriage partners. Interestingly enough, she also argues that the Train Man phenomenon was used to illustrate how the otaku "has the potential to become a new kind of ideal man, so long as he can acquire the looks and communication skills that make him desirable to women and help him conform to mainstream society." ${ }^{, 278}$ So Train Man showed the otaku that they too could be "normal" as well as showing mainstream society that the otaku are potential sources for romantic partners.

As of the late 2000s, the perception of otaku in Japan continues to shift, especially

\footnotetext{
275 Alisa Freedman, “Train Man and the Gender Politics of Japanese 'Otaku' Culture: The Rise of New Media, Nerd Heroes and Consumer Communities," Debating Otaku in Contemporary Japan: Historical Perspectives and New Horizons, Eds. Patrick W. Galbraith, Thiam Huat Kam, and Björn-Ole Kamm, London: Bloomsbury Academic, 2015, 129-146.

${ }^{276}$ Mizuko Ito, "Introduction," Fandom Unbound, xiv-xv.

277 Alisa Freedman, "Train Man and the Gender Politics of Japanese 'Otaku' Culture: The Rise of New Media, Nerd Heroes and Consumer Communities," 129-130.

${ }^{278}$ Alisa Freedman, "Train Man and the Gender Politics of Japanese 'Otaku' Culture: The Rise of New Media, Nerd Heroes and Consumer Communities," 139.
} 
for the Japanese government and businesses, which are beginning to capitalize on the idea of an "otaku culture." Numerous television programs have been broadcast in English, such as Japanology or Cool Japan on the television network Nippon Hōsō Kyōkai (NHK) (Japanese Broadcasting Corporation), which have promoted ideas of unique Japanese culture often associated with pop culture. Since 2010, the Japanese government has been actively promoting Japanese popular culture as a "soft power," referring to the allure and attraction of a country through culture and history rather than military coercion. ${ }^{279}$ In 2010 the Creative Industries Promotion Office was formed by the Japanese Ministry of Economy, Trade and Industry to actively promote the "Cool Japan" image or brand. ${ }^{280}$ Former Prime Minister Asō Tarō actively promoted anime, manga, and videogames as a source of soft power, going so far as to call himself an "otaku."281

Despite the allure of Japanese popular culture, as well as Japanese businesses and the Japanese government attracting tourists with "otaku culture," which is often the basis of the "Cool Japan" brand, the otaku still hold an odd position in society. They are both exploited and criticized or disregarded by mainstream society. The otaku have had a positive and impressive impact on the Japanese economy, being responsible for nearly $¥ 2$ Trillion (roughly $\$ 18$ billion) in a market that is targeted towards the otaku, whilst also being made available to mainstream Japan as well. ${ }^{282}$ With the conception of "Cool Japan," some scholars argue that the image of the otaku has changed and is beginning to take on more positive connotations. Philosopher and cultural critic Hiroki Azuma

\footnotetext{
279 See Douglas McGray, “Japan's Gross National Cool,” Foreign Policy 130 (2002): 44-54.

280 "Establishment of the Creative Industries Promotion Office," Ministry of Economy, Trade and Industry, 8 Jun 2010, Web, 31 Jan 2016.

${ }^{281}$ Thiam Huat Kam, "The Common Sense that Makes the 'Otaku': Rules for Consuming Popular Culture in Contemporary Japan,” Japan Forum 25.2 (2013): 151.

282 “Geek Spending Power: Otaku Business Gives Japan’s Economy a Lift,” Trends in Japan, Web Japan, 30 Aug 2005, Web, 28 Mar 2016. <http://web-japan.org/trends/business/bus050830.html>
} 
highlights what he sees as the recent success of otaku culture, such as famed animator Hayao Miyazaki's anime film, Spirited Away winning the American Academy Award for Best Animated film in 2003; the large success of pop artist Takashi Murakami's otakulike works that feature aspects of otaku culture and popular culture; and the inclusion of "otaku" featured in the Japanese pavilion during the 2004 International Architecture Exhibition of Venice Biennale (Biennale Architecture). ${ }^{283}$ Despite the capitalization of Japan's "gross national cool,” Azuma also points out:

"On the one hand, voices of authority within the mass media and pubic [sic] discourse still hold a strong loathing for otaku behavior, and the debate on otaku culture often faces resistance at that level, preempting any meaningful discussion. [...] On the other hand, otaku, who usually display an air of anti-authoritarianism, distrust any method that is not otaku-like and do not welcome discussion on anime and video games initiated by anyone other than an otaku." 284

The Japanese government and businesses, in addition to the otaku themselves, consider the otaku to be experts on the subject of Japanese pop culture. Within the otaku subculture, there appears to be a sense or idea of superiority to those who are non-otaku. After all, the otaku are experts in something that is being heavily promoted and their expertise unarguably has an influence on the pop products marketed in Japan. However, otaku have not reached the level of "geek culture" and "geek chic" that has become popular in the West. It is not considered "cool" to like cartoons, video games, or other things typically associated with the otaku in Japan. Many otaku do not outright claim their otaku identity. Many Japanese may read manga or watch anime, although they do so casually rather than as connoisseurs or professional critics which some otaku consider

\footnotetext{
${ }^{283}$ Hiroki Azuma, Otaku: Japan's Database Animals, xi.

${ }^{284}$ Hiroki Azuma, Otaku: Japan's Database Animals, 5.
} 
themselves to be.

In spite of the government's capitalization of the otaku subculture, many in Japan still stereotype the otaku as perverts and pedophiles. Many critics look to the otaku's preoccupation with lolicon, a term associated with anime that focuses on prepubescent girls, a portmanteau of "Lolita Complex."285 Due to the stereotyping of otaku and negative associations originally shared with it, television networks in Japan, particularly the NHK, prohibiting the word on-air. ${ }^{286}$ Many Japanese today associate otaku with young men who are "“lacking social skills and even common sense '; 'solitary and maladjusted'; 'pedophiles incapable of dealing with mature women.",287 This is contrary to the image of otaku that Hiroki Azuma presents, in which the otaku are informed consumers navigating Japanese society. They are consumers who know what they want and what they are doing.

Typically, male otaku are often portrayed negatively and as being undesirable to women. Otaku are often thought of as only male, but there are female otaku who may share the interests of a typical male otaku. In an excerpt of Tamaki Saitō's correspondence with a male otaku, the male otaku noted that his dream is to marry a female who turns out to be an otaku as well. ${ }^{288}$ If an otaku is dating a non-otaku girl and is sexually active, he will typically keep his fan behaviors and actions a secret. Dating a

\footnotetext{
${ }^{285}$ See Setsu Shigematsu, "Dimensions of Desire: Sex, Fantasy and Fetish in Japanese Comics," in Themes and Issues in Asian Cartooning: Cute, Mad and Sexy, Ed. J.A. Jent, Bowling Green: Bowling Green State University Popular Press, 1999, 127-163.

${ }^{286}$ Toshio Okada, "The Transition of Otaku and Otaku," Debating Otaku in Contemporary Japan: Historical Perspectives and New Horizons, Eds. Patrick W. Galbraith, Thiam Huat Kam, and Björn-Ole Kamm, London: Bloomsbury Academic, 2015, 168.

${ }^{287}$ Tamaki Saitō, “Otaku Sexuality,” Trans. Christopher Bolton, Robot Ghosts and Wired Dreams: Japanese Science Fiction from Origins to Anime, Eds. Christopher Bolton, Istvan Csicsery-Ronay, Jr., and Takayuki Tatsumi, Minneapolis: University of Minnesota Press, 2007, 225.

${ }^{288}$ Tamaki Saitō, Beautiful Fighting Girl, Trans. J. Keith Vincent and Dawn Lawson, Minneapolis: University of Minnesota Press, 2011, 39-41.
} 
non-otaku girl or a female otaku presents an opportunity to be perceived as "normal" by the rest of Japanese society, as well as by their girlfriend, as a sort of validation by society. Saitō does, however, point out that otaku "are sexual late bloomers [...] because they are unacquainted with the realities of sex, [therefore] they can pursue these sexual fantasies in a purer form."289 This purer form is often the pop culture figure they fantasize about, either through their objectification of figurines or through other masturbatory acts. Saitō's definition refers to the idea that sexuality does not necessarily require sexual experience. $^{290}$

Saitō does not criticize the otaku, but works to explain their behaviors and identity. His work attempts to depathologize the otaku, as evidenced by his refusal label them as "perverts" due to their masturbatory practices, instead insisting that their masturbatory acts do not replace their heteronormativity. ${ }^{291}$ Although he states, "what distinguishes an otaku from a non-otaku is whether he is able to 'get release' with an anime character." 292 J. Keith Vincent, the translator for Japanese psychiatrist and critic Tamaki Saitō's Beautiful Fighting Girl, explains, "Saitō's otaku recognize that, to the extent that the 'real world' is itself part of the Imaginary, there is no intrinsic difference between desiring a drawn or animated image and desiring an actual human being. ${ }^{, 293}$ For the otaku, their pop culture figure is just as important to their development as a relationship with an actual woman would be.

Japanese feminist scholar Mari Kotani is a bit more generous than most members

\footnotetext{
289 Tamaki Saitō, “Otaku Sexuality,” 229.

290 See Tamaki Saitō footnote in "Otaku Sexuality," 248.

${ }^{291}$ Tamaki Saitō, Beautiful Fighting Girl, 30-31.

292 Tamaki Saitō, Beautiful Fighting Girl, 30.

293 J. Keith Vincent, “Translator's Introduction - Making it Real: Fiction, Desire and the Queerness of the Beautiful Fighting Girl,” Beautiful Fighting Girl, Trans. J. Keith Vincent and Dawn Lawson, Minneapolis: University of Minnesota Press, 2011, xviii.
} 
of Japanese society in her view of otaku. She claims that they are not like ordinary men, and are similar to women in that they are marginalized by Japanese society. She explains, "In Japan, ordinary men adhere to the ideals of so-called salaryman society — in which men graduate from a university, enter a company, get married, buy a house, have children, send their sons to university, and expect to receive a pension and be taken care of by their wives when they retire. ${ }^{294}$ The otaku do not adhere to this standard, instead focusing on their hobbies and their interests. She also points out that female images in popular culture, like images of moe, are produced by the media and modified according to what consumers like. ${ }^{295}$ Kotani also states, "You could say that these images of women are independent of reality" and female characters "respond to very specific fantasies in a way that reality cannot." 296

Despite the efforts of Saitō and other scholars, as well as the earlier mentioned phenomenon, the term otaku and the perception of otaku are not free from negative connotations. However, scholar Kikuchi Satoru argues, "the easing of negative views about 'otaku' is linked with a general increase in the number of manga, anime and game fans. ${ }^{, 297} \mathrm{He}$ claims that this shift was found in the mid-90s after the success of the anime Neon Genesis Evangelion. In his 2007 survey and interviews with 368 undergraduate students, Kikuchi found that despite his optimism about the rise in positive reactions to the word "otaku" found that, "Nevertheless, more than half of the respondents answered that it was 'unpleasant' to be told by others that they had an 'otaku' tendency. [...] When

\footnotetext{
${ }^{294}$ Mari Kotani, "Memories of Youth," The Moé Manifesto: An Insider's Look at the Worlds of Manga, Anime, and Gaming, Ed. Patrick W. Galbraith, North Clarendon: Tuttle Publishing, 2014, 32.

${ }^{295}$ Concepts of moe will be further explained and examined in Chapter Four.

${ }^{296}$ Mari Kotani, "Memories of Youth," 36.

${ }^{297}$ Kikuchi Satoru, "The Transformation and Diffusion of 'Otaku' Stereotypes and the Establishment of 'Akihabara' as a Place-brand," Debating Otaku in Contemporary Japan: Historical Perspectives and New Horizons, Eds. Patrick W. Galbraith, Thiam Huat Kam, and Björn-Ole Kamm, London: Bloomsbury Academic, 2015, 153.
} 
someone else calls you an 'otaku,' it is still an insult." ${ }^{298}$ Whereas predominantly negative portrayals of the otaku still exist, there have been more positive portrayals of the otaku in recent years. In Kikuchi's research he highlights that despite the persisting negative associations of otaku stereotypes, there has been a change in more college age students having a positive response to the otaku. ${ }^{299}$ His survey shows that in 1998 positive responses to otaku were $17 \%$ of the people that participated in the study/survey, and in 2007 it grew to $34 \% .^{300}$

As recently as 2014, many Japanese still associate the otaku with varying levels of stereotypes, many of which are still negative. Japanese corporation Dream Idea Passion (Dip) held a survey concerning the otaku, garnering "a total of 1,843 responses from men and women between the ages of 10 and $49 .{ }^{, 301}$ Of the 1,843 that responded, 37.4 percent of them identified as otaku, but the 1,843 that responded only represent $.001 \%$ of the Japanese populace. While the Dip survey did not survey a large number of the population, not many Japanese are quick to identify themselves as otaku or those that identified as such in the survey did so because of the anonymity of online surveys. The survey also asked participants to respond to the question, "What comes to mind when you hear the word 'otaku?"' Responses varied with over 20 percent responding with various answers such as backpacks (23.5\%), someone who likes videogames (37.8\%), someone who likes manga (38.8\%), Akihabara/Akiba (45.6\%), someone who knows a lot about

\footnotetext{
${ }^{298}$ Kikuchi Satoru, "The Transformation and Diffusion of 'Otaku' Stereotypes and the Establishment of 'Akihabara' as a Place-brand," 159.

${ }^{299}$ Kikuchi Satoru, "The Transformation and Diffusion of 'Otaku' Stereotypes and the Establishment of 'Akihabara' as a Place-brand,' 159.

${ }^{300}$ Kikuchi Satoru, "The Transformation and Diffusion of 'Otaku' Stereotypes and the Establishment of 'Akihabara' as a Place-brand," 147-161.

${ }^{301}$ Casey Baseel, "What Do Japanese People Think of When They Hear the Word 'Otaku?'” Rocket News, 23 Apr 2014, Web, 25 Mar, 2016. <https://en.rocketnews24.com/2014/04/23/what-do-japanese-peoplethink-of-when-they-hear-the-word-otaku/>
} 
one thing (47.9\%), someone who likes anime (50.4\%), and someone obsessed with his or her hobby $(61.9 \%) .{ }^{302}$ These responses are rooted in very common stereotypes of the otaku, which are often included in most surveys concerning the otaku. But despite these stereotypes and lingering social stigmas, the otaku are still the ones to whom one can turn to for trends in computer electronics, and anime/manga pop products. The otaku, despite their perceived negative position within Japanese social hierarchy, are a group that can be exploited by the media, government, and corporations for their perceived "culture."

\section{IDENTITY THEORY AND THE FORMATION OF OTAKU IDENTITY}

To understand how the otaku structure notions of reality and their own identities, this section examines social identity and the constructions of reality. In a society like Japan, the individual is not separated from their collectivity and the "individual's innermost being is considered to be the fact of his belonging to the collectivity - the clan, the tribe, the nation, or what not." ${ }^{303}$ In Japan, people's social identity is typically based on their ingroups, such as what club they are in, where they go to school, and where they work. Social identity here can be “conceptualized as that aspect of a person's self-concept based on their group memberships; it [is] a person's definition of self in terms of some social group membership with the associated value connotations and emotional significance." ${ }^{304}$ Peter Berger points out, "Human role-playing is always dependent upon the recognition of others. The individual can identify himself with a role only insofar as others have identified him with it." ${ }^{, 305}$ Japanese students may identify themselves as students outside of school settings, but within school they are part of an ingroup, such as

\footnotetext{
302 Casey Baseel, "What Do Japanese People Think of When They Hear the Word 'Otaku?'”

${ }^{303}$ Peter L. Berger, The Sacred Canopy, 60.

304 John C. Turner, "Some Current Issues in Research on Social Identity and Self-Categorization Theories," 8.

${ }^{305}$ Peter L. Berger, The Sacred Canopy, 37.
} 
members of the baseball team or members of the culture club. These identities are strongly defined, and these are often the people that the individual will spend time with, inside and outside of school, well into college. ${ }^{306}$ These identities are so prominent that the otaku possibly embrace their identities as otaku due to it being the identity assigned to them by their peers and non-otaku.

Social identity is bound in one's relationships with other humans. Some common identifiers of ingroups can be religious, school- or work-related, or familial ties. Due to the "inevitable tensions of the processes of institutionalization, and by the very fact that all social phenomena are constructions produced historically through human activity, no society is totally taken for granted."307 The non-religious identity that Japanese claim to have could "indicate the lingering effects of the ideological control policies of the pre1945 period, which have fostered an ambivalent attitude towards 'religious religion,' understood in this context as a religion that transcends, or seeks to invert, the existing secular order of society. ${ }^{308}$ In other words, the Japanese do not identify themselves as being religious due to the historical events of World War II (1939-1945), and the dissolution of State Shintō, and the U.S. Occupation (1945-1952) following the war. It can be argued that religion is not a significant part of the Japanese social identity —at least not consciously. Rather, there appears to be a focus on a Japanese ethnic identity and the identity associated with one's ingroup or outgroup. Another major shift is that contemporary Japanese no longer identify with their ancestors as they did during the

\footnotetext{
${ }^{306}$ See David Ricky Matsumoto, "The Face of Emotion in Japan, II: Culture-Specific Aspects and Display Rules," Unmasking Japan: Myths and Realities about the Emotions of the Japanese, Palo Alto: Stanford University Press, 1996, 42-64.

${ }^{307}$ Peter L. Berger and Thomas Luckmann, The Social Construction of Reality, 106.

${ }^{308}$ Yukio Matsudo, "Back to Invented Tradition: A Nativist Response to a National Crisis," Religion and Social Crisis in Japan: Understanding Japanese Society Through the Aum Affair, Eds. Robert Kisala and Mark Mullins, New York: Palgrave, 2001, 172.
} 
Tokugawa and earlier periods, but instead identify with their ingroups. ${ }^{309}$

For as much as identities are formed within groups, they are also expressed based on interactions with the group and other groups. This can be traced back to early Japan when people identified with their clan or profession. Social identity can be "expressed through a desire to create, maintain or enhance the positively valued distinctiveness of ingroups compared to outgroups. $" 310$ Humans define and evaluate "themselves in terms of their group memberships." 311 Otaku define themselves by their hobby and compare themselves to other otaku with similar interests, which allow them to evaluate themselves. They are not concerned with a religious identity, but how they consume, treat, and understand the canon history or plot of an anime or manga is of great concern. As such, otaku identity, where popular culture is concerned, can be dictated by how others, particularly non-otaku, will identify them. They are defining themselves against what they are not.

The otaku identifies himself with the role that society identifies him with, and he is recognized as such. Eiji Ōtsuka claims, "We would do well to notice that among people in the cultural sphere of the non-West (hiseio-teki bunkaken), including Japan, there is a technique of survival (shoseijutsu) whereby one performs in accordance with the stereotypes and labels desired by others in order to avoid cultural friction." ${ }^{312}$ John Turner, notes that members of "low status group members [are] more discriminatory or ethnocentric than high status group members," or that they "show more outgroup

\footnotetext{
${ }^{309}$ During the Tokugawa period, people identified themselves by their family clan and affiliation with a daimyo, or feudal lord. The Meiji period (1868-1912 CE) saw the end of "backward" traditions, and while the family is still important in Japan, one began to be identified with the social groups they kept.

${ }^{310}$ Peter L. Berger, The Sacred Canopy, 8.

${ }^{311}$ Peter L. Berger, The Sacred Canopy, 8.

312 Eiji Ōtsuka, "Otaku Culture as 'Conversion Literature," xv.
} 
discrimination the more they identif[y] with some ingroup." ${ }^{313}$ In a similar vein, some otaku seem to regard themselves outside of or above the rest of Japanese "normal" society. Often times, some otaku will argue their superiority to Western fans of Japanese pop culture, as evidenced by message board posts referring to Westerners as "barbarians" or other derogatory terms - one only need to look at the various posts and comments on the internet message forum 2 channel. ${ }^{314}$ This suggests that, similar to the concept of a Shintō religious identity that is reserved solely for the Japanese, there is exclusiveness to being an otaku—one reserved for only those who are ethnically Japanese, implying that non-Japanese could not possibly understand and enjoy Japanese popular culture.

The otaku identify themselves as ethnically Japanese and as a part of Japan, yet they are also unique within Japanese society. As a group, the otaku began to use the term "otaku" as a way to identify themselves to one another and from non-otaku. They chose the term, but non-otaku also use the term to identify certain individuals as otaku, and often with negative connotations. One's sense of self is contained and expressed by the collective. With regard to identifying the self, John Turner points out:

"self is defined in terms of others who exist outside of the individual person doing the experiencing and therefore cannot be reduced to purely personal identity. At certain times, the subjective self is defined and experienced as identical, equivalent, similar or interchangeable with a social class of people in contrast to some other class. Psychologically, the social collectivity becomes self." 315

Among those who identify themselves as fans of something particular, the otaku stand out the most in their devotion to their hobbies. The otaku are different from other fans

\footnotetext{
${ }^{313}$ John C. Turner, "Some Current Issues in Research on Social Identity and Self-Categorization Theories," 9.

${ }^{314}$ See www.2ch.net.

315 Yukio Matsudo, "Back to Invented Tradition: A Nativist Response to a National Crisis,” 12.
} 
that may or may not use the term "otaku," such as baseball fans, music fans, and idol fans. There is a community element to the otaku, as found in other fandoms, but many otaku do not support organizations or clubs as members of baseball groups do- the otaku manage to be both individual and collective. ${ }^{316}$ They share a group identity but have individual practices, habits, and collections that they discuss with one another. Some Japanese scholars argue that the term "otaku" arose from its use at anime conventions as a convenient way for anime and manga fans to identify and refer to one another. ${ }^{317}$

An otaku's identity is formed through their consumption of popular culture particularly in the form of anime, manga, and videogames. It is "only through their consumption of both anime information and products [that] the otaku subject stabilize[s] his or her position in society." 318 They identify themselves against one another and "through passionately pursuing anime, otaku become visible to others. Thus the otaku must constantly consume anime in order to stabilize his or her subject position in society and secure an identity as 'otaku.",319 The otaku not only form their identity based on ingroups and outgroups, but they also form their identity through their consumptive practices and visibility to one another. The reason otaku used the term "otaku" to identify themselves to one another lies in its power as a means of crafting a space for themselves. The otaku's formation can be attributed to the society they live in, as the otaku are

\footnotetext{
${ }^{316}$ See William W. Kelly, "Sense and Sensibility at the Ball Park: What Fans Make of Professional Baseball in Modern Japan," Fanning the Flames: Fans and Consumer Culture in Culture in Contemporary Japan, Ed. William W. Kelly, Albany: State University of New York Press, 2004, 79-106.

${ }^{317}$ Kaichiro Morikawa, “おたく/ Otaku/ Geek,” Berkeley: Center for Japanese Studies UC Berkeley, 20 Apr 2012, Web, 13 Oct 2015.

${ }^{318}$ Lien Fan Shen, "Traversing Otaku Fantasy: Representation of the Otaku Subject, Gaze and Fantasy in Otaku no Video," Debating Otaku in Contemporary Japan: Historical Perspectives and New Horizons, Eds. Patrick W. Galbraith, Thiam Huat Kam, and Björn-Ole Kamm, London: Bloomsbury Academic, 2015, 82 .

${ }^{319}$ Lien Fan Shen, "Traversing Otaku Fantasy: Representation of the Otaku Subject, Gaze and Fantasy in Otaku no Video," 80.
} 
collectively a:

"product of hyper-capitalism and the hyper-consumption society ... Originally it was connected with a precise stereotyped image. It symbolized a human relationship for which the other forms of saying 'you' would be far too intimate. Otaku referred to the space between them, [in which] they are far from each other [and] not familiar. ... They are children of media and technology., 320

Among the many cultural nuances that influence and form the otaku's identity, adolescence is significant as an otaku may formulate their otaku identity as early as middle school. During middle school, one's group identity becomes an integral part of their development as a Japanese citizen. In Japan, this identity is formed when:

“one becomes aware of one's self, seeks, and is distressed with a unique status in the small society called school, where only people of the same age are gathered. People who are inferior in sports and sociability, or people who are conscious that their egos are strong and that they are different from the norm, tend to discover their identity in specialized hobbies and knowledge."321

Ingroup and outgroup is very important to one's social identity in most societies, and in Japan it has often times caused a problem with bullying, known as ijime. Bullying happens not just in school but also in the workplace, especially when one does not behave according to societal norms. Typically, in a school setting, bullying occurs when several students ostracize one classmate, and the rest of the class will follow suit, bullying the classmate. The bullying ranges from misplacing the student's shoes and verbal abuse to physical abuse. In many cases, the student being bullied does not fit in with or get along with the various groups that formulate in school. As such, otaku may experience bullying

\footnotetext{
${ }^{320}$ Qtd in Lien Fan Shen, "Traversing Otaku Fantasy: Representation of the Otaku Subject, Gaze and Fantasy in Otaku no Video," 76.

${ }^{321}$ Qtd in Miho Aida, "The Construction of Discourses on Otaku: The History of Subcultures from 1983 to $2005, " 115$.
} 
from classmates due to perceived inferiorities with regard to sports or sociability. In some cases, bullying escalates to such an extreme, that the student may stop attending school altogether, and this is often cited as a possible reason many school age children are becoming hikikomori, which means they become recluses who withdraw from society. ${ }^{322}$ Hikikomori are similar to the otaku because both groups are considered to be on the fringe of Japanese society, and the two are often conflated. They are viewed with suspicion because they can potentially upset the cohesion of Japanese society by not properly participating in society, if at all. Despite both groups sharing similarities in terms of their behaviors and the way that society regards them, they are not exactly alike. Hikikomori are not always otaku themselves, and many otaku are able to be active in the world whilst keeping their hobbies "compartmentalized." ${ }^{323}$ However, some otaku are perceived to have hikikomori tendencies, and will spend extended amounts of time in their rooms engaged in their personal hobbies. Yet, the otaku do not remain at home all of the time, as some are working part-time jobs or attending college. The hikikomori do not appear to self-identify as otaku and do not leave the house to form groups or act nearly as social as otaku. Unlike the hikokomori, the otaku are engaged with society at some point or another, whether it's going to a convenience store for food or working a part-time job.

Living in a world saturated with advertisements and media, the Japanese construct themselves accordingly in a social structure organized by ingroups and outgroups. Despite living in a global world, the Japanese still try to maintain a Japanese-ness that

\footnotetext{
322 The characters for hikikomori, 引き籠り, can be translated as a "pulling inward" or the word hiku which means to pull in and komoru which can mean to retire. See Marc Hairston, "A Cocoon with a View: Hikikomori, Otaku, and Welcome to the NHK," Mechademia 5 (2010): 311-323. See also, Sachiko Horiguchi, "Hikikomori: How Private Isolation Caught the Public Eye," A Sociology of Japanese Youth: From Returnees to NEETs, Eds. Roger Goodman, Yuki Imoto, and Tuukka Hannu Ilmari, New York: Routledge, 2012, 122-138.

${ }^{323}$ Marc Hairston, "A Cocoon with a View: Hikikomori, Otaku, and Welcome to the NHK," Mechademia 5 (2010): 313 .
} 
makes them separate and distinct from the rest of the world. This is evidenced in the sometimes neo-nationalistic behaviors and sentiments of otaku. Through depictions of otaku and hikikomori in Japanese popular culture, many misunderstand the way in which both subgroups are viewed in Japan. For instance, the series N.H.K. ni Yōkoso! [Welcome to the N.H.K.] depicts a protagonist who is a hikikomori and his (mis)adventures in Japan, such as confronting what he views to be the oddities of society. Although he is a hikikomori, much of the series is humorous, and intentionally so.

Many Western fans of anime and manga may be familiar with the term hikikomori, yet they have not tried using it to refer to themselves or others who may sequester themselves away from society. However, Western fans, such as Americans, have often used the term "otaku" to refer to themselves for some time. The term "otaku" entered the Western lexicon of fandom as a term to identify oneself as a lover of Japanese pop culture, long before being introduced into the Oxford Dictionary in $2007 .{ }^{324}$ In 1988 , the anime Gunbuster exposed the word "otaku” to Western fans and discussions of the term itself could be found on early Internet message boards. ${ }^{325}$ The negative implications of identifying as an otaku that are found in Japan are not found in the West. Many Western fans are often unaware of the negative connotations associated with the word, possibly due to the influx of Japanese popular culture that they find in the West.

\section{UNDERSTANDING THE CONNECTION OF RELIGIOUS ELEMENTS TO OTAKU IDENTITY AND BEHAVIORS}

The negative connotations of otaku and the popularity of Densha-Otoko [Train

\footnotetext{
${ }^{324}$ Alisa Freedman, "Train Man and the Gender Politics of Japanese 'Otaku' Culture: The Rise of New Media, Nerd Heroes and Consumer Communities," 137.

${ }^{325}$ See Lawrence Eng, "Strategies of Engagement: Discovering, Defining, and Describing Otaku Culture in the United States," Fandom Unbound: Otaku Culture in a Connected World, Eds. Mizuko Ito, Daisuke Okabe, and Izumi Tsuji, New Haven: Yale University Press, 2012, 85-104.
} 
Man], were events the otaku themselves had no control over. The media, such as news media or magazine columns, often affect the way in which the otaku are regarded, as seen with the coverage of Miyazaki's arrest and the Aum Shinrikyo. This reality is constructed for them and the otaku have little hand in constructing their social realities outside of the Internet. According to Peter Berger, reality is "a quality appertaining to phenomenon that we recognize as having a being independent of our own volition (we cannot 'wish them away')" and knowledge is "the certainty that phenomena are real and that they possess specific characteristics. ${ }^{, 326}$ Knowledge and reality are not the same for everyone, but knowledge gained from social reality guides conduct in their everyday lives. The otaku live in a society that is very rigidly structured. Japanese society and culture is immersed in tradition and Shintō is ever present as an ingrained way of life. Otaku, as well as all Japanese, grow up in this reality, possibly unconscious of the significance of many of their actions and practices. They gain knowledge from the social realities they face in Japanese society. As mentioned in the second chapter, Shintō's uniqueness derives from the fact that one cannot convert to Shintō; one must be born into it. ${ }^{327}$ For all Japanese, their religious identity is socially constructed for them from birth, whether they are aware of it or not.

However, when asked, most Japanese in Japan will claim that they are not religious, regarding themselves as 'non-religious' (mūshūkyō). This term, however, does not mean that they do not believe in anything, but rather it suggests that they do not feel a specific religion that requires time and personal commitment. ${ }^{328}$ It allows them to avoid any negative connotations centering around religious affiliation after the Aum Affair.

\footnotetext{
${ }^{326}$ Peter L. Berger and Thomas Luckmann, The Social Construction of Reality, 1.

${ }^{327}$ H. Byron Earhart, Japanese Religion, 38.

${ }^{328}$ Yukio Matsudo, "Back to Invented Tradition: A Nativist Response to a National Crisis," 171.
} 
While they do not feel they are religious, for the Japanese, especially the otaku, and most of humanity, everyday life presents itself as a reality that is interpreted by them and is "subjectively meaningful to them as a coherent world." ${ }^{, 29}$ They find meaning in their daily behaviors and practices, as well as the things they consume, because it helps them to make sense of the world around them.

Similarly, Westerners believe "religion implies that human order is projected into the totality of being. Put differently, religion is the audacious attempt to conceive of the entire universe as being humanly significant. ${ }^{, 330}$ However, Christians eventually choose to identify themselves as Christians and view the world that they live in as a gift from God. Unlike the Japanese, some Christians consciously make the choice to be Christian, or to become a part of any denomination they like. They can, at any time, decide to stop being practicing Christians. The Japanese, however, are born Shintō, whether they identify as so or not, and live in a world where they take the kami, spirits that permeate nature, for granted. ${ }^{331}$ The otaku also incorporate religious elements, such as devotionlike practices of food offerings to images of their favorite pop culture figures, and pilgrimage, into their consumption of popular culture. In Japanese culture, the boundaries between the sacred and the profane are ambiguous, and the otaku highlight the blurring of those lines.

Religion is also an identifier of one's ingroup, because religion provides an identity and provides a community element as well. Many people in general socialize and become a part of a religious community, which as a societal construct provides the

\footnotetext{
${ }^{329}$ Peter L. Berger and Thomas Luckmann, The Social Construction of Reality, 19.

${ }^{330}$ Peter L. Berger, The Sacred Canopy, 27-28.

${ }^{331}$ The Japanese are "born Shintō" because it is part of their ethnic identity and being born Japanese is also to be born Shintō. See H. Byron Earhart, Japanese Religion: Unity and Diversity, Belmont: Cengage Learning, 2004, 38.
} 
devotee an identity. One may argue that to be a part of such a community, one must be physically present. Humans are social creatures and the otaku are no exception, although a small group they have been labeled and given an identity by society, so they still help shape and constitute the make-up of a community. However, they are often a part of an online community, such as an online gaming community. Similarly, hikikomori who are completely withdrawn from society, manage to participate in certain aspects of society also using message boards or online video games to communicate with others. Humans construct their own nature and essentially construct themselves, often by externalizing themselves through activities. ${ }^{332}$ Despite the fact the hikikomori withdraw from society and physically social interactions, they still have access to the Internet and an online community and world. They can be "active" in an online message board, posting and commenting, or playing online games with others. They still have access to a community, and within this community are other hikikomori and otaku that share in their love of a particular pop product or anime figure - the pop culture figure. While their discussions do not appear as "religious" in an explicit sense, they are not praying or praising a traditionally established divinity, they are displaying devotional-like behaviors towards their pop culture figures and instructing others on how best to understand, purchase, or find products associated with their pop culture figure. They engage in discussion about the representation of the pop culture figure, whether she is aesthetically pleasing to otaku sensibilities, and so on. The idea that "religion requires a religious community, and to live in a religious world requires affiliation with that community" can be applied to the cult-like practices of the otaku and hikikomori, but it does not constitute an official

332 Peter L. Berger and Thomas Luckmann, The Social Construction of Reality, 49, 52. 
religious identity. ${ }^{333}$ Nor does it mean that their figure of devotion or pop culture itself is meant to replace any canonical kami or the Shintō religion itself.

People who convert to a religion or a specific way of life and wish to remain converted will engineer their life accordingly. ${ }^{334}$ Japanese are born Shintō, and their way of life is structured within their day-to-day practices for them by tradition and social structure. Shintō practices and identity are taken for granted in Japanese culture and society, as well as which identity they are born into and in which they are socialized and educated. People shape their identities according to the already-established social structures put in place by society, which allows them to interact with others who share a similar identity and to shape any new emerging social structures. ${ }^{335}$ As such, the otaku do not need to go to great lengths to take the intuitive knowledge that they have as Japanese citizens and integrate them into their own personal lives, interests, and interior worlds. They spontaneously incorporate these religious elements into their own behaviors and practices. According to Japanese sociologist Osawa Masachi, otaku are attracted to mysticism and pseudoreligions that rely on themes commonly found in Japanese pop culture and subcultures. In his own examination of the otaku, Hiroki Azuma references Masachi's theory and asserts:

'In [Masachi's] 1995 article 'On Otaku' ('Otaku ron'), he claims that, for the otaku, there is a 'discord' in distinguishing between the intrinsic other and the transcendental other; and for this reason otaku are strongly attached to the occult and mysticism. This 'distinction between the intrinsic other and the transcendental other,' put plainly, means the distinction between the world of the other that surrounds one's own self (the experiential world)

\footnotetext{
${ }^{333}$ Peter L. Berger and Thomas Luckmann, The Social Construction of Reality, 158.

${ }^{334}$ Peter L. Berger, The Sacred Canopy, 50.

${ }^{335}$ George Herbert Mead, Mind, Self, and Society: From the Standpoint of a Social Behaviorist, Chicago: University of Chicago Press, 2009, 201.
} 
and the godly world that transcends it (the transcendental world). The otaku cannot distinguish between these two, with the result that they are easily hooked on pseudoreligions that draw on themes popular in various subcultures. In a modern society, such disorder would have been dismissed as personal immaturity, but in postmodern society it is not so simple, because the very society in which we live is something now characterized by the 'disorder' of the grand narrative. The behavioral pattern of the otaku precisely reflects this characteristic of postmodernity. After having failed to grasp the significance of a 'god' or 'society' supported by tradition, otaku try to fill the void with the subculture at their disposal." 336

In a contemporary Japanese consumer society, otaku are no longer able to recognize "god" or a "society" supported by Japanese traditions and so they rely on popular culture or subcultures to fulfill the spiritual voids left by a materialistic world. The otaku are using Shintō elements from a traditional and normative world to construct a postmodern pop culture world. This is possibly due to the suppression of notion of "structured" religions stemming from WWII or due to the nature of Shintō, which is not so easily divorced from the Japanese identity. The otaku create kami-like beings in the figures that become objects of their devotion. These figures are disposable, able to be replaced anytime to fulfill new needs and new voids. Popular culture consumption is being blended with religious elements and religious sites are using popular culture to encourage visitors. With otaku behavior, popular culture becomes intertwined with religion in a certain sense, but nothing in an official capacity.

\section{CONCLUSION}

For the otaku, their object of fantasy, their pop culture figure, ${ }^{337}$ "lack[s] any

\footnotetext{
${ }^{336}$ Hiroki Azuma, Otaku: Japan's Database Animals, 26.

337 The use of figure here denotes the confluence of anime, manga, pop idol, and the actual figurine of the animated/illustrated characters that otaku devote themselves to. Thus, figure is all of these things simultaneously.
} 
correspondent in the real world" and it "is in an effort to become the possessor of these figures that male otaku construct the various illusions around them: fiction/criticism, novels, dōjinshi, and so forth."338 While otaku fantasize about fictional female figures, some women in Japan have decided that an otaku might be a viable option for dating because, as Kotani suggests, they are not like other men. Japanese research company, Goo Research, polled over one thousand women in 2013 and noted that some women found desirable traits in otaku. Some of the traits that are considered desirable are: [otaku] were faithful, knowledgeable about technology, a limited social circle, it is easy to take the lead of the relationship due to lack of experience which also means there is no baggage or ex-girlfriends, and they are not desperate for female attention—not "skirt chasers" among several other traits. ${ }^{339}$ These ideas about the desirable traits of otaku set them apart from non-otaku men who would be considered to be "skirt chasers," concerned about social circles, and not willing to give the "lead of the relationship" to their girlfriends. The survey itself neglects the possibility that the otaku might not be interested in a relationship with a human girl rather than their pop culture figure.

As such, there is definitely a caveat to accepting such polls at face value, and that is although one thousand Japanese women found some desirable traits, that does not mean that they are dating otaku or that the rest of women in Japan feel similarly. There is something to be said about non-otaku women wanting otaku because they can mold the otaku to fit to their desired image of what a boyfriend and standards. There is a sense of irony in the fact that male otaku build and customize anime figures they love and that non-otaku women see the potential to customize the otaku to their own specifications.

\footnotetext{
${ }^{338}$ Tamaki Saitō, “Otaku Sexuality,” 231, 234.

339 “女子が「付き合いたい!」と思うオタク男子の魅カランキング,” Goo Ranking, Goo Research, 5 Mar 2013, Web, 13 Oct 2015.
} 


\section{CHAPTER FOUR: FROM FETISHIZED ICON TO POP CULTURE KAMI: OTAKU INCORPORATION OF RELIGIOUS ELEMENTS WITH POP CULTURE}

The otaku, as has been argued, are among the largest consumers of anime and manga pop culture in Japan, influencing the pop products released in Japan, as well as providing a "cool culture" that appeals to both Japanese and non-Japanese. Japanese businesses and the government have commodified otaku culture in an effort to boost tourism. Despite this commodification of and the popularity of "otaku culture," the otaku are not often highly regarded within Japanese mainstream society. They are considered deviant and problematic, damaging the image of Japan, and posing a direct threat to the birth rate of Japan due to their desire for fictional and two-dimensional characters rather than flesh-and-blood women. ${ }^{340}$ Earlier chapters in this dissertation have examined theories associated with the roles of religion and economy in Japan, provided a historical overview of religion in Japan, and discussed the formation of the otaku identity as it emerged as a counter-culture within mainstream Japanese society.

Modern popular culture is often associated with mainstream society and is so multi-faceted, including popular music, television, film, video games, and comic books among others. The Oxford Dictionary defines pop culture as "modern popular culture

\footnotetext{
${ }^{340}$ See Chapter Three for a discussion of Otaku identity and Tamaki Saitō, "Otaku Sexuality," Robot Ghosts Wired Dreams: Japanese Science Fiction from Origins to Anime, Eds. Christopher Bolton, Istvan Csicsery-Ronay Jr., and Takayuki Tatsumi, Minneapolis: University of Minnesota Press, 2007.
} 
transmitted via the mass media and aimed particularly at younger people."341 This chapter analyzes the behaviors and practices of the otaku, a subculture of fans within Japanese society, and their relationship to pop culture as it pertains specifically to anime and manga. The otaku's behaviors and practices in consuming pop culture is unique when compared to those who would be considered part of the mainstream or normal. In this case non-pop culture would refer to those who would not consider pop culture as an important part of their subculture or ingroup. ${ }^{342}$

This chapter will examine the otaku's role as part of a contemporary socioreligious phenomenon in which they are incorporating Japanese religious traditions and elements in their consumption of popular culture, but it should be noted that they are not replacing or reformulating Shintō itself, nor does it appear they are attempting to create a new religion. The otaku are selectively adapting specific Shintō religious elements in their consumption of popular culture. They are manifesting a practice of adopting and adapting cultural elements from Japanese culture that has been deeply rooted within Japanese history.

\section{OTAKU: TYPICAL FANS VERSUS EXCESSIVE CONSUMERS}

In Japan, the term "otaku" has been used to refer to males who are excessive fans of anime and manga, but can also be related to other types of excessive fans, such as train otaku. ${ }^{343}$ This dissertation is concerned with the otaku who are male, in their late teens to late thirties, and who are particularly concerned with anime and manga. Many

\footnotetext{
341 “Pop Culture,” Def.1. OxfordDictionaries.com, Oxford Dictionaries, n.d., Web, 23 Jun 2017. $<$ https://en.oxforddictionaries.com/definition/pop_culture $>$

342 Typically, pop culture is regarded as a low form of art as opposed to a high form of art, such as a comic book versus a series of etchings like those by Rembrandt. More recently, this line of thought appears to be changing as evidenced by the growth of studies in pop culture.

${ }^{343}$ Train otaku are noted for their love of trains, such as the bullet trains in Japan. They will crowd train platforms to take pictures of the trains as they pull into the station.
} 
descriptions of the otaku include or are centered on their behaviors. Tamaki Saitō, a Japanese psychiatrist known for his work with young introverts, particularly the otaku, lists four descriptors for otaku: 1) otaku have an affinity for fictional contexts (kyoko no kontekusuto), 2) they resort to fictionalization in order to possess the object of their love, 3) they have multiple orientations when it comes to enjoying fiction, and 4) fiction can be a sexual object for the otaku. ${ }^{344}$ These descriptors can be related and connected to most otaku behaviors. For example, otaku of the 1980s were noted for their refusal to give up what was considered children's culture, specifically manga and anime, most of which feature adolescent protagonists. ${ }^{345}$ The otaku then engage in various levels of discourse examining and discussing the series with particular regard to a seiy $\bar{u}$ 's, or voice actor/actress, acting abilities. They also critique a series' artistic direction, story development, and so on. Fan created works that relate to popular series are not uncommon, such as fan art or fan fiction. The otaku are no exception and create fan works such as dōjinshi, fan-made comics. By creating dōjinshi, or dōjin for short, fans can recreate or explore their favorite characters and series in a more intimate manner. For the otaku, they can engage with fiction at many levels: as critic, consumer, and "lover." Additionally, there are theories as to how the term originated, including debate about how to write otaku in Japanese, as well as discourse concerning otaku generations. ${ }^{346}$ Ian Condry argues that the term "otaku" is, in fact, "a slight misnomer in the sense that people who identify as these kinds of devoted fans today tend to use the

\footnotetext{
344 Tamaki Saitō, "Otaku Sexuality,” 227.

345 See Eiji Ōtsuka, “Otaku Culture as 'Conversion Literature,'” Debating Otaku in Contemporary Japan: Historical Perspectives and New Horizons, Eds. Patrick W. Galbraith, Thiam Huat Kam, and Björn-Ole Kamm, London: Bloomsbury Academic, 2015, xiii-xxix.

${ }^{346}$ See Debating Otaku in Contemporary Japan: Historical Perspectives and New Horizons, Eds. Patrick W. Galbraith, Thiam Huat Kam, and Björn-Ole Kamm, London: Bloomsbury Academic, 2015.
} 
shortened version 'ota' (katakana 'wo' and ' $t a$ '), in part as a way to distinguish themselves from older generations of otaku. ${ }^{347}$ This distinction of how to label one's self within the generations of otaku points to a difficulty in pinpointing a definitive identity of or definition of the otaku. ${ }^{348}$ Nevertheless, it is not just the identity and etymology of the word otaku that should be taken into account; also of note is the perception and acceptance of otaku within Japanese society.

Chapter Three discussed the formation of an otaku identity, as well as the perceptions of and the otaku's role within mainstream society. The otaku have many conflicting perspectives, but the most accepted perspective is that the otaku are not highly regarded outside of being considered tech-savvy consumers. The consumptive practices of the otaku are also often scrutinized negatively ${ }^{349}$ For instance, the "fanaticism of collectors is colloquially rendered in Japanese as byōki (a sickness)." ${ }^{, 50}$ This "fanaticism" appears to have included certain religious elements into the practices and behaviors centering on popular culture. As has been discussed, this dissertation is concerned with otaku behavior and practices, as they appear to relate some incorporation of religious tradition through consumption of popular culture. Of particular interest to this dissertation is the otaku's devotion to anime and manga characters.

\section{TYPES OF FANS}

Typical fan behaviors are considered obsessive by mainstream standards. To "many nonfans, especially among the professional and upper middle classes, [the fans]

\footnotetext{
${ }^{347}$ Ian Condry, The Soul of Anime, 188.

${ }^{348}$ For an in-depth and historical examination of the otaku, see Debating Otaku in Contemporary Japan: Historical Perspectives and New Horizons, Eds. Patrick W. Galbraith, Thiam Huat Kam, and Björn-Ole Kamm, London: Bloomsbury Academic, 2015.

${ }^{349}$ See Appendix B for fieldnotes regarding most Japanese non-otaku's reactions.

${ }^{350}$ Shuhei Hosokawa and Hideaki Matsuoka, "Vinyl Record Collecting as Material Practice: The Japan Case," Fanning the Flames: Fans and Consumer Culture in Culture in Contemporary Japan, Ed. William W. Kelly, Albany: State University of New York Press, 2004, 165.
} 
are either the 'obsessed individuals' or the 'hysterical crowd.",351 In the United States, fans are sometimes considered something other than "normal." Fans obsessively watch or read a series, closely analyze character behaviors, engage in creative works of fiction involving their favorite series, ${ }^{352}$ and visit the real-life locations of their favorite television shows and movies. ${ }^{353}$ These types of behaviors are also found among fans in Japan; however, the otaku exhibit particular fan behaviors that go beyond these examples. While it is not uncommon for a fan to "seek intimacy with the object of their attention," the otaku, and many other types of Japanese fan, try to possess their objects, "paradoxically, seeking intimacy in highly commodified settings." 354 The objects of otaku desire, the pop culture figure, are often elevated to the status of an object of devotion and fantasized about. People may purchase products with their favorite celebrities on them, but they do not "normally" sit down to a dinner with an image of a celebrity or a favorite anime or manga character, a practice that will be discussed later in this chapter.

During a visit to an arcade in Nara on May, 30, 2016, one otaku mentioned that he played UFO machines, a claw machine game, if the machine had items with his favorite character on them. ${ }^{355}$ At first glance, this may appear similar to what could be considered "normal" fan behavior, but upon closer inspection the otaku behaviors move past what could be considered normal by obsessively collecting duplicate items with their favorite

\footnotetext{
${ }^{351}$ Qtd in William W. Kelly, "Introduction: Locating the Fans," 1.

352 See Henry Jenkins, Textual Poachers: Television Fans and Participatory Culture, New York: Routledge, 2012; See also Fan Fiction and Fan Communities in the Age of the Internet: New Essays, Eds. Karen Hellekson and Kristina Busse, Jefferson: McFarland, 2006.

${ }^{353}$ See Will Brooker, "Everywhere and Nowhere: Vancouver, Fan Pilgrimage and the Urban Imaginary," International Journal of Cultural Studies 10.4 (2007): 423-444; See also Matthew Hills, Fan Cultures, New York: Routledge, 2013.

${ }^{354}$ William W. Kelly, "Introduction: Locating the Fans," 1, 9.

${ }^{355}$ Personal Interview. Nara, Japan. 30 May 2016.
} 
character on it, taking their figures to locations featured in the series associated with the figure, or having dinner with those figures. In Japan, the socially accepted type of fan that exists between otaku and non-otaku would be the mania, shortened from the word "maniac." A mania is someone who is able to function socially and who adheres to the normative expectations of Japanese society, such as holding a job and participating in society-essentially a "normal" fan. ${ }^{356}$ One scholar, Kaichiro Morikawa, claims that one of the differences between mania and otaku is the objects of their obsessions; mania are obsessed with "materiality (jittai) while otaku tend to focus on virtual things such as manga and anime." 357 The mania maintain a status quo and "grow up," whilst the otaku refuse to give up their hobbies that are often seen as immature. Japanese culture does not reject one being a fan or having hobbies, but hobbies should not interfere with being a productive member of society.

Traditionally, Japanese culture has shown itself to be inclined towards various types of fandom: Kabuki theater, sumo wrestling, and baseball among other non-pop culture fandoms. William W. Kelly examines whether the Japanese are inclined to be "fans by national character." 358 He asserts, "there may well be certain historical and contemporary features of social practices in Japan that give impetus and form to certain fan patterns." ${ }^{359}$ Fan-like behaviors can be traced back to the Tokugawa (1600-1868 CE) and Meiji (1868-1912 CE) periods, when fans of the Japanese theatre knew as much as possible about favorite Kabuki actors or collected netsuke, a toggle that fastened the cord

\footnotetext{
356 Toshio Okada and Kaichiro Morikawa, "Otaku Talk," moderated by Takashi Murakami, translated by Reiko Tomii, Japan Society, n.d., Web, 25 Nov 2016. <http://www.japansociety.org/otaku_talk>

357 Toshio Okada and Kaichiro Morikawa, "Otaku Talk."

${ }^{358}$ William W. Kelly, "Introduction: Locating the Fans," 10-11.

${ }^{359}$ William W. Kelly, "Introduction: Locating the Fans," 11.
} 
for personal containers or pouches that held documents, money, and other miscellanea. ${ }^{360}$ These behaviors of collecting are not far removed from the contemporary behavior of the otaku. Hiroki Azuma says of otaku behavior, "once the otaku are captivated by a work, they will endlessly consume related products and derivative works through database consumption." ${ }^{361}$ Like those before them, and as Kelly notes, the most basic otaku behavior - collecting and its derivatives — have long been a part of Japanese culture.

\section{COLLECTING}

Collectors are the most common among Japanese fans. The act of collecting can be broken down into three modes: 1) souvenir, 2) fetishistic, and 3) symbolic. ${ }^{362}$ The souvenir collector "creates a romantic life-history by selecting and arranging what might be called an object autobiography, where the objects are at the service of the autobiographer." ${ }^{363}$ For the fetishistic collector, the "objects are dominant and ... are allowed to create the self of the collector who just responds to his obsessive need by gathering as many items as possible." ${ }^{364}$ The third mode, systematic collecting, is "based on an intellectual rationale that emphasizes the completeness of assembled items. ${ }^{, 365}$ These three modes "are not exclusive, and individual collections can embody all of them." ${ }^{366}$ These three types of collecting correspond to otaku consumption behaviors,

\footnotetext{
${ }^{360}$ See Gary Leupp, Male Colors: The Construction of Homosexuality in Tokugawa Japan, Berkeley: University of California Press, 1995; Jacob Raz, Audience and Actors: A Study of Their Interactions in the Japanese Traditional Theater, Leiden: E.J. Brill, 1983; See also Lorie Brau, "Rakugo Fans at Play: Promoting the Art, Creating Community, Inventing Sales," Fanning the Flames: Fans and Consumer Culture in Culture in Contemporary Japan, Ed. William W. Kelly, Albany: State University of New York Press, 2004, 127-149.

${ }^{361}$ Hiroki Azuma, Otaku: Japan's Database Animals, Trans. Jonathan E. Abel and Shion Kono, Minneapolis: University of Minnesota Press, 2009, 105.

${ }^{362}$ See Susan Pearce, "Collecting Reconsidered," Ed. Susan Pearce, Interpreting Objects and Collections, New York: Routledge, 1994, 193-204.

${ }^{363}$ Qtd in Hosokawa and Matsuoka, "Vinyl Record Collecting as Material Practice," 155.

${ }^{364}$ Qtd in Hosokawa and Matsuoka, "Vinyl Record Collecting as Material Practice," 155.

${ }^{365}$ Hosokawa and Matsuoka, "Vinyl Record Collecting as Material Practice," 155.

${ }^{366}$ Hosokawa and Matsuoka, "Vinyl Record Collecting as Material Practice," 155.
} 
especially with regard to pop culture items. For instance, otaku will go to great lengths to collect not only all items in a set, but also purchase multiple items of a particular product to have, use, and just because — often otaku perform all three modes at the same time. One need only visit one of the numerous shops in Akihabara in Tokyo, Japan. Many shops had shelves and all available space lined with figurines, video games, and many other products for sale. One shop I visited in June 2016 had narrow aisles, shelved crowded with items. As I observed patrons dressed in stereotypical clothes so often associated with otaku, they perused the lines of figurines, many I had seen in the arcades nearby. If an otaku needed one figurine to complete their collection, they only needed to go to one of these nearby shops, or the Internet, to find their missing piece.

Some collector otaku consider themselves to be professional critics or connoisseurs of the products that they collect and consume. Indeed, some scholars consider the otaku to be "professional spectators," much like professional film critics; however, among "contemporary otaku, there seems to be more of an interest in information for its own sake, and in the technology of acquiring and maintaining that information, than would be the case among the more traditional professional spectator. ${ }^{, 367}$ Similarly, Azuma notes that the otaku have a desire for searching for knowledge, with help from search engines, and have "no intrinsic reason for the search to end." ${ }^{368}$ The otaku continually display a desire for knowledge (which they consume from the Internet), such as learning as much as possible about a product, character, and so on. This desire for knowledge is also expressed, as Azuma states, "in the passion of trading-

\footnotetext{
${ }^{367}$ Lorie Brau, "Rakugo Fans at Play: Promoting the Art, Creating Community, Inventing Sales," Fanning the Flames: Fans and Consumer Culture in Culture in Contemporary Japan, Ed. William W. Kelly, Albany: State University of New York Press, 2004, 136.

${ }^{368}$ Hiroki Azuma, Otaku: Japan's Database Animals, 104.
} 
card collectors to 'the complete' (i.e., to collect all cards in a set), in the passion of 'girl games' players to check all branches, and in the passion of collectors of derivative works, which sustains numerous exhibitions and sales of events of fanzines." ${ }^{369}$ This desire for knowledge is often associated with the act of collecting, especially where the otaku is concerned. The souvenir collector otaku will gather items such as trading-cards to create a full narrative accessible to the collector as a type of object "autobiography" narrated by the objects. The otaku also desire to collect items displaying their favorite characters which allow them to be present at all times, such as numerous key chains adorning a backpack, cell phone charms, and pins. ${ }^{370}$

\section{POP IDOLS AND EXCESSIVE CONSUMERS}

Kelly highlights the fact that fans are "excessive consumers." Indeed, in "disposition and behavior, they exceed the mass of ordinary spectators, viewers, and readers of mass culture in a number of ways: in focus, time, and energy in the intensity of meaning they make and intimacy that they establish with their objects of attention.",371 Like a typical fan, the otaku also engage in these behaviors but in a way that highlights their excessive consumerism. At Comiket, the largest comic book convention in Japan, the otaku spend the day visiting the booths of doujinshi mangaka, fan comic artists, or groups who are selling their doujin, fan made comics. ${ }^{372}$ The creators of doujin are often fans themselves, devoting their time and energy to creating their own versions of an already established series. They create new stories and relationships with characters from the series they like. The otaku will also purchase multiple copies of items, often noting

\footnotetext{
${ }^{369}$ Hiroki Azuma, Otaku: Japan's Database Animals, 104-105.

${ }^{370}$ See Appendix B where many otaku were observed with charms, key chains, and so on dangling from their backpacks.

${ }^{371}$ William W. Kelly, "Introduction: Locating the Fans," 7.

${ }^{372}$ See Appendix A Figure 4.8 for a map of Comiket.
} 
that multiple copies are required so that "they have one to use, one to display, and one just because."373

Another example of this excessive consumption are the idol otaku. They are fans obsessed with pop music singers or girl bands. These singers are known as pop idols or pop idol groups. One popular girl idol group is AKB48, a group named after Akihabara and the original 48 members of the group, which as of July 2016 had 124 members. ${ }^{374}$ AKB48 participate in promotional events known as "hand-shaking events," allowing fans the opportunity to shake the hands of the various members of the group. These handshaking events are a promotional strategy by sponsors, group mangers, advertising companies, and TV broadcasters to allow the fans to be closer to their idols than is possible with most other pop idol groups. ${ }^{375}$ To attend these types of events, fans must purchase the group's CDs to receive tickets. Fans are limited to mere minutes to shake hands and take a photo, and the number of minutes varying according to each event. This practice has resulted in a boom in music revenue in Japan because fans are buying multiple copies of the same CD. ${ }^{376}$ Some fans have committed fraud in order to purchase

\footnotetext{
${ }^{373}$ Japanese colleagues and some otaku I spoke with in Akihabara often cited this as a reason for purchasing more than one item of something they liked. These objects were usually figurines and special editions of manga magazines or tanköbon, chapters collected into a volume similar to that of a graphic novel.

374 “AKB48 公式サイト|メンバー情報 [AKB48 Official Site — Member Information],” Official AKB48 Website, n.d., Web, 13 Jul 2016. < http://www.akb48.co.jp/about/members/> The number of members changes due to various factors, such as girls "graduating" (i.e. becoming too old to be in the group), leaving, joining, and so on.

${ }^{375}$ Minoru Matsutani, “Girl Idol Group About Mass Exposure, Fans,” The Japan Times, 24 Aug 2010, Web, 25 Jul 2016. <http://www.japantimes.co.jp/news/2010/08/24/reference/girl-idol-group-about-massexposure-fans/>

${ }^{376}$ One fan bought roughly $\$ 300,000$ worth of CDs. See Casey Baseel, "AKB48 Fan Shows His Love the Only Way He Knows How: Buying \$300,00 Worth of CDs,” Rocket News 24, 22 May 2014, Web, 5 Jul 2016. <http://en.rocketnews24.com/2014/05/22/akb48-fan-shows-his-love-the-only-way-he-knows-howby-buying-300000-worth-of-cds/ >; See also Mariko Yasu, "Girl-Group Handshake Fans Push Japanese Music Past U.S.," Bloomberg Technology, Bloomberg, 3 Jul 2013, Web, 20 Jul 2016.

$<$ https://www.bloomberg.com/news/articles/2013-07-03/girl-group-handshake-fans-push-japanese-musicpast-u-s->
} 
multiple CDs to spend more time with their idol, such as one fan who had used a fake ID to purchase multiple CDs. ${ }^{377}$

These hand-shaking events are "aimed at selling more CDs by harnessing the fans' energy, defined in terms of the quantity of consumption" as well as exploiting the fans by promising "an experience of greater qualitative intimacy and connection with" their favorite idols. ${ }^{378}$ Fans are encouraged to vote for favorite idols with their "love," that is, by purchasing CDs that contain voting cards sent in to determine the "most popular idol." Some criticized this way of voting for popular idols, claiming that it was an abuse of the voting system because people were not limited to one vote at a time, and not due to the fact that someone purchased roughly $200 \mathrm{CDs}$ that they then threw away in the trash. ${ }^{379}$ While fans can clearly be excessive in their consumption of popular culture, the Japanese government, media, and many companies recognize that the fans, specifically the otaku, are key for marketing and generating revenue.

\section{PASSION AND DEVOTION THROUGH MOE}

The otaku use the term "moe" to express their love for and the feeling they get from anime characters; the term is also sometimes used to describe an aesthetic style of the description of two-dimensional figures. The otaku's desire for and devotion to the pop culture figure is directly related to the marketing and consumption of pop culture. Ian Condry explains the concepts of moe thus:

$$
\text { "...the notion of moe ('moh-ay'), which is loosely a term }
$$

\footnotetext{
377 Tokyo Reporter Staff, "Kyoto Man Obtained Fake ID for AKB48 'Handshake' Tickets," Tokyo Reporter, 7 Jan 2016, Web, 20 Jul 2016. <http://www.tokyoreporter.com/2016/01/07/kyoto-man-obtainedfake-id-card-for-akb48-handshake-tickets/>

${ }^{378}$ Patrick W. Galbraith and Jason G. Karlin, "Introduction: The Mirror of Idols and Celebrity," Idols and Celebrity in Japanese Media Culture, Eds. Patrick W. Galbraith and Jason G. Karlin, New York: Palgrave Macmillan, 2012, 21.

${ }^{379}$ See Idols and Celebrity in Japanese Media Culture, Eds. Patrick W. Galbraith and Jason G. Karlin, New York: Palgrave Macmillan, 2012.
} 
for affectionate longing for 2D characters or, more accurately, a reference to an internalized emotional response to something, generally with no hope for a reciprocal emotional payback. In discussions about the cultural significance of anime in Japan, the idea of moe is also associated with larger questions about how fans relate to virtual characters and worlds and, in turn, about the power of media producers vis-à-vis consumers. For some writers, moe constitutes a 'love revolution' - that is, an example of pure love and a logical extension of the shift from analog to digital technology. For another theorist, moe symbolizes a postmodern, 'database' form of consumption, whereby today's otaku reject the experience of the larger stories of anime and favor instead the piecemeal sampling of elements of 2D characters." ${ }^{, 380}$

The word moe is derived from the Japanese verb moeru, which means to bud or sprout. ${ }^{381}$

The kanji for moe acts as a visual reference to the shift in maturity for illustrated girls who are on the cusp of becoming young women. The kanji character itself is "written with the grass (kusa) radical on top and the character for 'bright, cheerful' (i.e., the sun and moon together) underneath." 382 Indeed, many of the two-dimensional figures represent pre-adolescent or high school age girls. These characters are often referred to as moe kyara, or moe characters.

According to Tamaki Saitō, and the otaku themselves, moe is a feeling more than sexual desire. ${ }^{383}$ For the otaku, moe is a noble feeling, like that of a big brother, because it is tied up in their desire to protect purity and innocence. Condry explains that as a feeling moe:

"does not refer to girls per se but to the yearning desire to care for, or nurture, them. In this sense, it is also a pun on moeru (to boil, to burn), which is with a different kanji and can also be viewed as a reference to a heated sensual desire.

\footnotetext{
${ }^{380}$ Ian Condry, The Soul of Anime, 187.

381 Tamaki Saitō, "Otaku Sexuality," 230.

382 Ian Condry, The Soul of Anime, 191.

383 Tamaki Saitō, “Otaku Sexuality,” 230-231.
} 
The term moe is troubling to some people in Japan because it apparently centers on an inappropriate desire by relatively grown men for (imaginary) immature girls." 384

While some, such as Saitō, will argue that moe does not have sexual elements, and could be considered chivalrous in the original European understanding of the word, the writing of the kanji and the pun mentioned above suggest otherwise. ${ }^{385}$ For the purposes of this dissertation, moe refers to the general love and devotion otaku have for their pop culture kami, which often borders on sexual dynamics. Some otaku become upset if the moe characters engage in sexual activity with a fictional male, because "once actual sex is portrayed, the fantasy is destroyed. ${ }^{386}$ However, while it can be argued that moe is not meant to be sexual, that does not stop some otaku from sexualizing moe figures. For example, some otaku make sexually explicit doujin that feature moe characters from popular series such as Lucky ¿`Star or Love Live!. There are also numerous products otaku can purchase products featuring moe characters in sexual situations, such as sex toys or eroge [erotic games], such as Kanon (1999) for the PC. ${ }^{387}$

Moe is not just a visual aesthetic; it can also be associated with character traits, typically those associated with a young girl. In some anime or manga series, a character needs to be moe as it becomes an important element for character development or the plot of the series as it develops. Azuma Hiroki asserts, most "moe-elements are visual, but there are other kinds of moe-elements, such as a particular way of speaking, settings,

\footnotetext{
384 Ian Condry, The Soul of Anime, 191.

${ }^{385}$ In some arguments, the otaku's feelings of moe are chivalrous like those of a knight's unconsummated love for a lady, however, it should be noted that there was really no similar concept of this chivalry in the samurai tradition or aesthetics.

${ }^{386}$ Patrick Macias and Tomohiro Machiyama, Cruising the Anime City: An Otaku Guide to Neo Tokyo, Berkeley: Stone Bridge Press, 2004, 50.

387 Toshihiko Sato, “On Magical Girls and Male Fans (Part One)," Ed. Patrick W. Galbraith, The Moé Manifesto: An Insider's Look at the Worlds of Manga, Anime, and Gaming. North Clarendon: Tuttle Publishing, 2014, 47.
} 
stereotypical narrative development, and the specific curves of a figurine." ${ }^{388}$ Azuma also notes that the otaku tend to excessively purchase certain items due to feeling moe towards a particular character, and argues that the "success of a project for the producers of such goods is directly determined not by the quality of the work itself but by its ability to evoke the moe desire through character design and illustrations." ${ }^{389}$ Clearly, the design of characters and subsequent product development is geared towards a male otaku audience, which should come as no surprise considering many character designers are or were otaku themselves. Traditionally speaking, this relationship between the otaku and pop culture figure has no parallel to Shintō but the moe aesthetics have been applied to characters related to Shintō elements, such as the depiction of miko, shrine maidens, such as Tsukasa Hiiragi in Lucky 2 々 Star.

\section{KAWAII MASCOTS IN JAPAN: EVOKING AN EMOTIONAL RESPONSE}

Mascots are numerous in Japan. There are anime-inspired mascots for many cities and all prefectures in Japan, such as Shiromaru-hime who is the mascot for the city of Himeji in Hyōgo, Japan. ${ }^{390}$ These figures are officially known as yuru-chara, which loosely means "light-hearted characters,",391 and they are mascot characters that are used for a variety of purposes such as promoting a business, boosting tourism, and so on. ${ }^{392}$

\footnotetext{
${ }^{388}$ Hiroki Azuma, Otaku: Japan's Database Animals, 42.

${ }^{389}$ Hiroki Azuma, Otaku: Japan's Database Animals, 48.

${ }^{390}$ See Appendix A Figure 4.1, and Appendix B for information on the mascots in Uji and Himeji.

391 Philip Brasor, "The Obsession Over Those Dumbed Down Cute Mascots," The Japan Times, 3 Aug 2008, Web, 29 Sep 2017. <https://www.japantimes.co.jp/news/2008/08/03/national/media-national/theobsession-over-those-dumbed-down-cute-mascots/\#.WhHJMxNSyRs $>$

${ }^{392}$ In Japan, it is not uncommon to make contractions of words. In this case, the full name of these characters is ゆるいマスコットキャラクター (yurui masukotto kyarakutā), or "light-hearted mascot character." The first word ゆるい (yurui) can be translated numerous ways, such as loose, gentle, weak, light-hearted, or unimportant. See Philip Brasor, "The Obsession Over Those Dumbed Down Cute Mascots,” The Japan Times, 3 Aug 2008, Web, 29 Sep 2017.

$<$ https://www.japantimes.co.jp/news/2008/08/03/national/media-national/the-obsession-over-thosedumbed-down-cute-mascots/>
} 
In Japan, these mascots often adhere to the aesthetic idea of kawaii, or cuteness. ${ }^{393}$

Laura Miller notes that throughout Japan there are anthropomorphic "characters founds in divination typologies, regional tourism campaigns, religious character goods, etiquette guides, and public service posters." ${ }^{394}$ Kawaii itself is considered a philosophy of sorts and the aesthetic cuteness that these characters embody has been difficult to clearly define. Hiroko Yoda and Matt Alt provide insight into the role of kawaii:

"Cuteness so completely permeates modern Japanese art and life that it transcends mere subculture. It is effectively a philosophy, complete with its own proponents and critics. Detractors claim the childlike obsession with cuteness is a form of passive rebellion, indicative of a growing detachment from reality among a certain segment of young Japanese citizens. Others argue that the worship of things kawaii is a healthy escape from the trials of daily life and merely a recent manifestation of aesthetic traditions dating as far back as the seventeenth century.",395

These ideas of kawaii, sometimes coupled with moe, are finding their way into the designs of mascots for religious sites. One of the best-known characters that embodies the kawaii aesthetic, both inside and outside of Japan, is Hello Kitty. Her image graces any number of products found in Japan, from cosmetics and snack foods to stationery and guides on etiquette. For Westerners, it may come as a shock that she is also featured on items sold at religious sites in Japan. Zen and Shin Buddhist temples have sold amulets and cell phone straps featuring her face or dressed in Japanese Buddhist garb. ${ }^{396}$ Elisabetta Porcu explains:

"Hello Kitty is used by religious institutions with a long-

\footnotetext{
393 Takie Sugiyama Lebra, The Japanese Self in Cultural Logic, Honolulu: University of Hawai'i Press, $2004,86$.

${ }^{394}$ Laura Miller, “Japan’s Zoomorphic Urge,” ASIANetwork Exchange 17.2 (2010): 69.

${ }^{395}$ Matt Alt and Hiroko Yoda, Hello, Please! Very Helpful Super Kawaii Characters from Japan, San Francisco: Chronicle Books, 2007, 10.

${ }^{396}$ Elisabetta Porcu, "Pop Religion in Japan: Buddhist Temples, Icons, and Branding," Journal of Religion and Popular Culture 26.2 (2014): 158.
} 
standing tradition $[\ldots]$ to add a distinctive international/global, and thus 'modern,' flavor to the objects they are introducing into the market and, as a consequence, to the institutions themselves. At the same time, these institutions are trying to keep their products associated with an ancient (religious) tradition, like in the case of cell phone straps featuring Hello Kitty linked to the wisteria crest of the Honganji and the head temple, and thus maintain their 'traditional' Japanese flavor.",397

Hello Kitty's image can also be found with Shintō iconography, such as a golden Hello Kitty sitting in front of a miniature torii, which was found in the shopping area in Miyajima outside of the Itsukushima Shrine in the Hiroshima prefecture. ${ }^{398}$ Thus a reciprocal relationship between pop culture and religious groups exist, pointing to antecedents and connections that link the otaku's consumption of pop culture and their incorporation of religious elements into their practices.

The shifting of the roles between pop culture and religious traditions has roots in traditional Japan. Similarly, the use of mascots is not really new, as shrines and temples had proto-mascots prior to the twentieth century. Hiroko Yoda and Matt Alt describe historical and cultural roots of Japan's personification of inanimate objects and abstract concepts into mascots:

"Traditional Japanese agrarian culture stressed the value of inter-dependence: one's family, friends, neighbors, and even the land, sea, and sun formed a complex web of relationships that required proper recognition and appreciation. This way of thinking extended to inanimate objects and, in particular, to tools that helped make daily life easier. In fact, old shrines of gratitude to used sewing needles, knives, eyeglasses can still be found throughout Tokyo and the Japanese islands - a whimsical synthesis of Buddhist beliefs in the relational nature of life and of the animism underlying Japan's native religion, Shintō. [...] Then and now, the Japanese possess a knack for

\footnotetext{
${ }^{397}$ Elisabetta Porcu, "Pop Religions in Japan: Buddhist Temples, Icons, and Branding," 159.

${ }^{398}$ See Appendix A Figure 4.2.
} 
transforming inanimate objects and abstract concepts into characters, complete with their own names, personalities, and even histories." 399

Similar practices are witnessed among the otaku in their devotion to the characters they see in anime. Some religious sites are beginning to reflect otaku aesthetics in their use of mascots, such as the creation of Toro Benten. The creation of Toro Benten by the Ryōhōji Temple, a Nichiren Buddhist temple, highlights the use of a moe-inspired anime mascot meant to attract patrons.

The character is based on Benzaiten, the Buddhist deity of "eloquence, knowledge, music, and the arts," but was renamed Toro Benten and is depicted as a young fashionable woman dressed in pink. ${ }^{400}$ In 2009, a newly formed company known as Hachifuku and a female illustrator named Toromi were hired to create Toro Benten to attract a larger audience to the shrine, one that was younger than the temple's elderly members. ${ }^{401}$ The temple also features several other deities that have been redesigned to reflect similar aesthetic changes, such as Kishimojin, a demon protector of Buddhism, becoming Mama, a purple haired woman with a crying baby. The temple even has its own theme song, "Tera zukkyun! Ai no Ryōhō-ji," and it was performed at a miniconcert held at the temple in $2010 .^{402}$

Clearly, this is one example of a Buddhist temple in Japan incorporating pop culture in their advertising and the products being sold onsite. Mascots are being used to encourage parishioners and raise revenues. The otaku are not creating mascots for any

\footnotetext{
${ }^{399}$ Matt Alt and Hiroko Yoda, Hello, Please! Very Helpful Super Kawaii Characters from Japan, 12.

${ }^{400}$ Elisabetta Porcu, "Pop Religion in Japan: Buddhist Temples, Icons, and Branding," Journal of Religion and Popular Culture 26.2 (2014): 162.

${ }^{401}$ Elisabetta Porcu, "Pop Religion in Japan: Buddhist Temples, Icons, and Branding," 162.

${ }^{402}$ Elisabetta Porcu, "Pop Religion in Japan: Buddhist Temples, Icons, and Branding," 164. See Appendix A Figure 4.3.
} 
economic reasons or to gain followers. They merely consume and devote themselves to these figures without desire for economic, social, or political gain. To fully appreciate not only the influence of pop culture on these religious traditions or the otaku whose behaviors border on devotion-like, we must also consider other religious forms of devotion and how they are related to this idea of evoking emotions. Other Asian religious traditions have devotional practices to create emotional bonds between the devotee and the object of devotion. Unlike the aesthetic concepts of moe and kawaii in Japan, other traditions, such as the bhajan in Hinduism, focus on ritual actions and devotional music to create a bond with the deity. ${ }^{403}$

\section{POINTS OF COMPARISON TO OTHER RELIGIOUS FORMS OF DEVOTION}

To help understand the otaku's feelings and devotional practices towards their pop culture figure, a comparison can be drawn to idol worship and devotion found in other religions. Two of these religions are Buddhism and Hinduism, which involve idol worship and devotion. While there is nothing as emotionally intense as moe in Buddhism, in Hinduism the relationships between the devotee and the devoted can be intensely emotional akin to moe, without the sexual dimensions. These relationships often feature intense emotion, asking for blessings, and the devotee recognizing their role as subordinate to the deity they are worshipping. ${ }^{404}$ As could be argued with most

\footnotetext{
${ }^{403}$ The bhajan is a genre of devotional music that is aligned with bhakti in Hinduism. See Natalie Y. Moore, "In Hindu Worship, Music is Gift to Gods," Chicago Tribune, 12 May 2006, Web, 18 Nov 2017. < http://articles.chicagotribune.com/2006-05-12/news/0605120279_1_hindu-temple-rama-temple-songs $>$ See also James G. Lochtefeld, The Illustrated Encyclopedia of Hinduism: A-M, New York: The Rosen Publishing Group, 2002, 97.

${ }^{404}$ Bhakti devotion contains the bhāvas, attitudes that a devotee may direct towards the Hindu deity. These attitudes are formed from a range of emotional attitudes such as a "placid love" to an "attitude of a woman towards her lover." Swami Akhilananda, Hindu Psychology: Its Meaning for the West, London: Routledge,
} 
devotional relationships in religion, the relationship is one that is imagined and specific to the individual. In the case of the otaku, however, the relationship is one that is preferred to a relationship with an actual living person. This relationship draws parallels to those found in Hinduism and even shares some of the levels of emotional intensity, but the otaku are not effectively subordinate to their object of devotion and they do not ask the pop culture figure for blessings. It also by coincidence that moe shares a level of intense emotion such as that found in Hindu bhakti, but notably there is no such intensity in Shintō. The adapted Shintō, Buddhist, and Japanese ritualized behaviors are providing a venue for the expression of moe. The otaku's relationship with their pop culture figure provides them feelings of love and an intense emotional connection like those typically associated with lovers.

The otaku are taking elements from Shintō and adapting them to their consumption of popular culture. They take practices and ideas, such as the devotional behaviors found with worshipping the kami, and intertwine them with popular culture consumption. For instance, otaku will purchase wooden prayer tablets, illustrate them with an image of their pop culture figure, and then hang them at their local Shintō shrine that the otaku associate her with. ${ }^{405}$ A few Shintō shrines have begun to capitalize on this, offering official wooden prayer tablets with the images of these anime and manga characters already provided or selling trinkets that bear the image of the characters at the

1999, 180. See also Karen Pechelis, "Bhakti Traditions," The Continuum Companion to Hindu Studies, Ed. Jessica Frazier, New York: Continuum Publishing, 2011, 107-121.

${ }^{405}$ See Danny Choo, "Ita-Ema," Culture Japan, 5 Jan 2014, Web, 18 Nov 2017. $<$ http://www.dannychoo.com/en/post/27129/Ita+Ema.html $>$ See also "New Twist on Traditions in the Otaku Mecca Akihabara! Fully Illustrated 'Ita-Ema' Will Bring You a Year of Happiness?!," Tokyo Otaku Mode, Jan 11 2014, Web, 18 Nov 2017. <https://otakumode.com/news/52cc27df637d52606b000522/NewTwist-on-Traditions-in-the-Otaku-Mecca-Akihabara!-Fully-Illustrated-\%E2\%80\%9CItaEma\%E2\%80\%9D-Will-Bring-You-a-Year-of-Happiness-!> 
shrine. ${ }^{406}$ A relatable point of comparison for a similar phenomenon of fictional characters being treated with devotional-like reverence would be the Hindu deity Santoshi Maa. She originally started out as a fictional character who was comprised of elements from other Hindu goddesses and was later legitimized and recognized as an official Hindu deity through her relationship to her father, Ganesha. ${ }^{407}$ She appears in the Bollywood film Jai Santoshi Maa $(1975)^{408}$, which became immensely popular, resulting in people performing rituals before the movie started, and even entering the theater barefoot as they would with a Hindu temple. ${ }^{409}$ Hence, India's similar economic circumstances have possibly led to a similar phenomenon where the distinction between deity or fictional character is becoming ambiguous.

While Santoshi Maa was a fictional creation with a loose basis in Hindu scripture who became an official deity, Japanese fictional characters have not made a similar transition nor are they created with the explicit idea that they will become $k a m i{ }^{410}$ There are no Shintō shrines which have canonized the otaku's pop culture figures, nor do they replace any canonically recognized kami. The otaku are not replacing Shintō with popular

\footnotetext{
${ }^{406}$ See my discussion of the Kanda Shrine and Jōrin-ji Temple in Chapter Four, Section IV. Otaku and Shrines. See also Ken Iikura-Gross, "Touring the Real-Life Anohana," Anime News Network, News, 25 Mar 2016, Web, 15 Jul 2017. <http://www.animenewsnetwork.com/feature/2016-03-25/touring-the-reallife-anohana/.100253>.

${ }^{407}$ For an overview and analysis into the relationship to Ganesha and the recognition of Santoshi Maa, see Anita Raina Thapan, Understanding Ganapati: Insights into the Dynamics of a Cult, New Delhi: Manohar Publishers, 1997.

${ }^{408}$ John Stratton Hawley, "The Goddess in India: One Goddess and Many, New and Old," Devĩ: goddesses of India, Eds John Stratton Hawley and Donna Marie Wulff, Delhi: Motilal Banarsidass Publishing, 1998, 3 .

${ }^{409}$ See John Stratton Hawley, “The Goddess in India: One Goddess and Many, New and Old," Devĩ: goddesses of India, Eds John Stratton Hawley and Donna Marie Wulff, Delhi: Motilal Banarsidass Publishing, 1998, 1-28.

${ }^{410}$ Santoshi Maa is loosely based on a Vedic deity and folk tale, the Vrat Katha, but was not the focus of early cults. See Philip Lutgendorf, “Jaa Santoshi Maa Revisited: On Seeing a Hindu 'Mythological' Film," Representing Religion in World Cinema: Filmmaking, Mythmaking, Culture Making, Ed. S. Brent Plate, New York: Palgrave Macmillan, 2003, 19-42. See also Philip Lutgendorf, "A 'Made to Satisfaction Goddess': Jai Santoshi Maa Revisited (Part Two),” Manushi 131 (2002): 24-37.
} 
culture but are conflating certain Shintō elements with their consumption of popular culture. This points to a shift and a potentially new role of pop culture within Japanese religions. A small number of Shintō shrines, and Buddhist temples, have begun to use anime-styled mascots. ${ }^{411}$ As will be discussed later in this chapter, some shrines and temples have begun a reciprocal relationship with the otaku, using otaku subculture to their advantage and moving beyond the otaku, into the mainstream where anime and manga have begun to appeal to non-otaku in Japan.

Despite these pop culture figures not purposely being made with the intention to become kami, some of these figures are often linked to certain shrines, temples, and other real life locations. ${ }^{412}$ It may be that particular artists, often otaku themselves, work closely with a particular town or shrine to help boost the economy. This reciprocal relationship between the otaku and the religious sites is relative to particular locations within Japan — as will be seen in the contrast between the Washinomiya Shrine and the Kanda Shrine. Not all shrines have officially adopted an anime or manga series to be associated with them. The use of anime characters as official mascots in non-otaku spaces can be found throughout Japan, which reflects an impact of otaku influence in addition to the growing popularity of Japanese pop culture. Two examples of non-otaku spaces using anime mascots are the Kyoto Gakuen University, which uses a fictional student as their

\footnotetext{
${ }^{411}$ The Washinomiya and Kanda Shintō shrines, as well as the Ryōhō-ji Buddhist temple have close associations with anime characters. In the case of the Ryōhō-ji Temple, an anime character, Toro Benten, was created as a mascot for the temple. The Washinomiya Shrine is associated with the anime Lucky 2 Star and its annual festival features a portable shrine with Lucky $\succsim$ Star characters on it; while the Kanda Shrine named an anime character from Love Live! as its official mascot.

${ }^{412}$ As of my own research, there have been no works, artists, or scholars who have stated that there are any anime or manga characters being created with the intention of becoming a kami. For discussion and information on shrines and temples using anime and manga series, see Chapter Four, Section III.1 and Section IV.
} 
mascot; ${ }^{413}$ and the Hatsukaichi Municipal Library in Hiroshima, which features anime characters based on the Japanese version of the library decimal classification system. ${ }^{414}$

\section{OTAKU BEHAVIORS AND PRACTICES}

The historical overview of religion in Japan presented in Chapter Two highlighted how religion has adapted to various historical events and cultural transitions. The discussion in Chapter Two included the absence of clear boundaries between sacred and profane, an example of which was the fluctuations of the Emperor's status historically. The Emperor's role and connection with Shintō was often affected by the political powers and devotional practices of the Japanese. Over the course of Japanese history, devotional practices shifted from worshipping the family kami to an amalgamation of various clan kami, then to the Imperial family, and finally, in the modern period the Imperial family being transformed into celebrities in postwar Japan.

While there were celebrities in the Tokugawa period, such as the many geisha and theater actors, they became more accessible after WWII due to the growth and accessibility of television. By the mid-2000s, it was not uncommon for two-dimensional animated characters from popular franchises, were being featured on many commodities made and sold in Japan, from arcade games and public transportation to cosmetics and candy. For example, cosmetic company Creer Beaute features Lady Oscar and Marie Antoinette from Berusaiyu no Bara [Rose of Versailles] (1972) on their waterproof

\footnotetext{
${ }^{413}$ Kyoto Gakuen University created an official anime character named Sono Uzumasa, who has been featured in commercials and advertising for the university. See Oona McGee, "Kyoto Gakuen University Entices Students with TV Ads Featuring Official Anime Character," Rocket News 24, 7 Jul 2015, Web, 27 Jun 2017. <http://en.rocketnews24.com/2015/07/07/kyoto-gakuen-university-entices-students-with-tv-adsfeaturing-official-anime-character/> See Appendix A Figure 4.4.

${ }^{414}$ Casey Baseel, "Wow, Literature is Cute! Hiroshima Library Designs Anime Mascots for Decimal Classifications," Rocket News 24, 27 Sep 2014, Web, 29 Sep 2017.

$<$ https://en.rocketnews24.com/2014/09/27/wow-literature-is-cute-hiroshima-library-designs-animemascots-for-decimal-classifications/> See Appendix A Figure 4.5.
} 
mascara line. ${ }^{415}$ Pop culture themes and idols are ubiquitous in Japanese advertising, manufactured commodities, and tourist sites in Japan. In the case of the Washinomiya Shrine and Kanda Shrine, anime heavily influenced the role of the shrines in the economy of the areas in which they are located. There are even anime-inspired mascots for many cities and all prefectures in Japan, such as Shiromaru-hime who is the mascot for Himeji, Hyōgo, Japan. ${ }^{416}$

Before examining the behaviors and practices of the otaku, it is relevant to note that the otaku's behaviors are individualistic rather than communal. Their religiosity is limited to the individual. When considering the religious-like elements that are a part of otaku practices and behaviors, they tend to do most these practices in a solitary manner, with the exception of anime pilgrimages where they may accompany a friend. There are no official doctrines or common prayers, rather they seem to be focused on the here and now. The closest that the otaku come to "common prayers" are those who fill out the wooden prayer tablets at Shintō shrines asking for a fictional character to be their wife or to wish her a happy birthday. Officially speaking, the otaku do not share any particular links to any religious denomination or congregation, more than likely due to the common claims of being non-religious (mūsh $\bar{u} k y \bar{o})$.

The otaku perform religious-like pilgrimage; they have objects of devotion, which they revere and venerate. The otaku are known for their large collections of manga, figurines, and video games. They are also known for being socially awkward and not

\footnotetext{
${ }^{415}$ Riyoko Ikeda's Rose of Versailles, while published in Margaret magazine from 1972 to 1973, is still often referenced in contemporary manga and anime, as well as serving as a popular subject for the Takarazuka theater which specializes in musicals featuring all women troupes. See Appendix A Figure 4.6. ${ }^{416}$ See Appendix A Figure 4.1, and Appendix B for information on the mascots in Uji and Himeji. These figures are officially known as yuru-chara, and are mascot characters that are used for a variety of purposes such as promoting a business, boosting tourism, and so on.
} 
having any interest in anything other than their hobbies. Their mostly isolated behavior and rejection from the mainstream society is reminiscent of monks living sequestered away from the secular world. The otaku prefer to dwell within the presence of their pop culture figure or solely within a world of pop culture. The line between pop culture and reality are becoming as blurred as the lines between sacred and profane. Shintō shrines, while recognized as sacred and religious sites, have profane things such as vending machines for ice cream, drinks, and even toys located within shrine grounds. The otaku further blur these lines between the sacred and profane by bringing pop culture, in the form of figurines or dressing up as their favorite characters, into Shintō shrines and Buddhist temples.

\section{PILGRIMAGE}

Shintō shrines and Buddhist temples have long been destinations for pilgrims. In contemporary Japan, some Shintō shrines and Buddhist temples have become sites of "pilgrimage" for the otaku. Traditionally, speaking, pilgrims would refer to their pilgrimage as "seichi junrei," which can be translated as a "holy land pilgrimage" or "pilgrimage to a sacred place." ${ }^{417}$ Otaku use this same term to refer to their own journeys to places such as the Washinomiya and Kanda shrines. In strictly religious terms, the original purpose of a pilgrimage was a devotional journey undertaken to a particular holy site for purposes including becoming closer to a specific deity or even a required act of faith, such as those found in Christian pilgrimages. Edith Turner pointed out in her preface to Image and Pilgrimage in Christian Culture: Anthropological Perspectives,

\footnotetext{
${ }^{417}$ The characters 聖地 meaning “sacred ground” and 巡礼 meaning “pilgrimage.” Jim Breen, “聖地巡礼 【せいちじゅんれい】,”Jim Breen's WWWJDIC, n.d., Web, 18 Nov 2017. $<$ http://nihongo.monash.edu/cgi-bin/wwwjdic?1E $>$ See also Daniel Park, "Seichi Junrei - Visiting the Holy Sites of Japanese Anime," METAculture Gurashii, 30 Sep 2016, Web, 18 Nov 2017. $<$ http://www.gurashii.com/seichi-junrei-visiting-the-holy-sites-of-japanese-anime/>
} 
that a pilgrimage "is not a search for a dusty, dead past, or nostalgia" but that a pilgrimage "is the journey to the actual place containing the actual objects of the past, whose very stones seem to emit the never-obliterated power of the first event - a certain shadowy aura." ${ }^{418}$ Turner and her husband Victor Turner examine Abrahamic traditions and Western religion, but similar ideas can be found in the pilgrimage of the otaku to sites otaku deem as sacred. One fan noted the Washinomiya Shrine as being a "holy site" in an interview published in The Wall Street Journal. ${ }^{419}$ For a traditional visitor to a Shintō shrine or a Buddhist temple, the shrine itself is a holy site. In the case of the otaku their attachment to their pop culture figure and her link to the shrine or temple makes it a "holy" site.

The presence and importance of shrines and temples, including the religious figures associated with those sites, were often depicted in anime and manga during the gekiga, or drama pictures, movement (1957-1980s). ${ }^{420}$ In the more dramatic manga series, there were Buddhist monks and Shintō priests featured among a number of samurai and ninja, or these characters would battle with one another in a scene featuring a nameless shrine or temple looming in the background. In addition to manga, there is a long tradition of illustrated narratives featuring various religious figures and sites in Japanese literature dating back to the earliest writings in the early Nara Period (710-794 CE) to the contemporary period. ${ }^{421}$ This connection to these religious sites and use of

\footnotetext{
${ }^{418}$ Edith Turner, "Preface," Image and Pilgrimage in Christian Culture: Anthropological Perspectives, by Victor Turner and Edith Turner, New York: Columbia University Press, 1978, xv.

${ }^{419}$ Hiroko Tabuchi, "Popular Cartoon Series Makes Japanese Shrine a Magnet for Fans: Devotees are Mainly Young Men, Who Dress Like the Characters - In Miniskirts," The Wall Street Journal, 30 Jul 2008 , Web, 10 Apr 2016. <https://www.wsj.com/articles/SB121737740486095275>

${ }^{420}$ Refer to Chapter Two, Section I.6 for a discussion of gekiga.

${ }^{421}$ According to the Metropolitan Museum of Art, the "earliest extant illustrated handscroll in Japan is a work showing episodes from the life of the Buddha, and was created in the eighth century." Anna
} 
religious figures from Japanese religion is nothing new. Most Japanese visit shrines and temples out of tradition and social obligation. The contemporary anime characters meet tradition in these locations, existing in an actual place where objects of the past and present coexist, linking the past with the present.

Acts of pilgrimage associated with pop culture similar to this are also found in Western fandoms, and Western fans often consider visiting shooting locations as pilgrimages, such as fans of the $X$-Files visiting locations in Vancouver, Canada. ${ }^{422}$ However, the religious connections and connotations found in otaku fandom are not present in Western fandom. American fans might visit a church used in a shooting location, but they are not likely to partake of ritual behaviors or worship services as the otaku would. Many times the otaku themselves partake of religious activities at Shintō shrines, such as purchasing ema, having their fortunes read, and so on. ${ }^{423}$

Matthew Hills, a fandom scholar, believes that for Western fans, the "cult geography," or the sacred focal point of cult fans touristic pilgrimage is not a matter of social or communal ritual; rather, the pilgrimage itself is an affective-interpretive process, which redefines material space. ${ }^{424}$ This may be true for Western fans, but for Japanese fans it is a social or communal ritual. Western fandom may consider a location to be "sacred," yet the site itself is not a religious site and the fans do not show a similar reverence as an otaku might. The Washinomiya Shrine and Kanda Shrine in Japan are actual ritual spaces—living Shintō shrines that have active worshippers attend the shrine

Willmann, "Japanese Illustrated Handscrolls," The Metropolitan Museum of Art, Nov 2012, Web, 18 Nov 2017. <https://www.metmuseum.org/toah/hd/jilh/hd_jilh.htm>

${ }^{422}$ See Will Brooker, "Everywhere and Nowhere: Vancouver, Fan Pilgrimage and the Urban Imaginary," International Journal of Cultural Studies 10.4 (2007): 423-444.

${ }^{423}$ See Appendix B where several otaku were seen at Washinomiya Shrine admiring the ema and the one otaku who purchased an ema from the shrine. Also seen were both otaku and non-otaku visitors to the Kanda Shrine who prayed and purchased various items.

${ }^{424}$ Matthew Hills, Fan Cultures, New York: Routledge, 2013, 110 
for religious purposes where the otaku themselves may worship. Unlike the original meaning of the word 'pilgrimage' and somewhat different from the Western fandom sense of the word, the otaku visit these locations and still recognize them as religious sites. Otaku pause and pray at the shrines as the otaku I observed at the Washinomiya and Kanda Shrine did. One fan of Lucky $\Sigma$ Star was quoted as saying of the Washinomiya Shrine, "For us, this is a holy site," while dressed in cosplay of Konata, one of the main

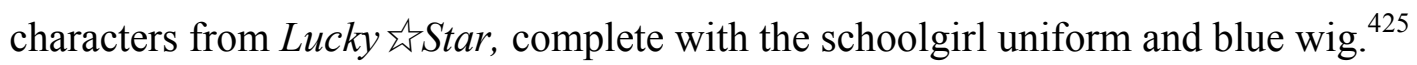

As mentioned above, the Japanese government and various companies in Japan commodify these otaku behaviors in order to make money from the tourism that they stimulate. Various travel companies and websites, such as Trip Advisor, offer

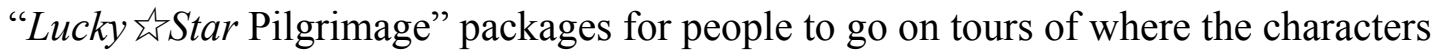
would have visited. Historian of religion, Mircea Eliade theorized, "the cosmic symbolism of sacred space is so old and so familiar that many are not yet able to recognize it." ${ }^{426}$ Japanese otaku may not recognize any cosmic symbolism in their lives, pop culture, and actions, but they are aware that there is something "holy" or "sacred" about visiting the shrine or locations associated with their beloved pop culture figure. Browsing online message boards or social media, such as 2 channel or Twitter, one can find many similar reactions and feelings about sites like the Washinomiya Shrine and Kanda Shrine being "holy." On Twitter alone, many Japanese Tweets included the word “聖地巡礼,” seichi junrei meaning “sacred pilgrimage,” as a hashtag when discussing

\footnotetext{
${ }^{425}$ Hiroko Tabuchi, "Popular Cartoon Series Makes Japanese Shrine a Magnet for Fans: Devotees are Mainly Young Men, Who Dress Like the Characters - In Miniskirts."

${ }^{426}$ Mircea Eliade, "The World, the City, the House," Experience of the Sacred. Eds. Sumner Twiss and Walter Cosner, Hanover: University Press of New England, 1992, 199.
} 
visits to the Washinomiya Shrine or about the shrine in general. ${ }^{427}$ One user noted that they, "Went to Washinomiya Shrine and visited the sacred pilgrimage site," after describing the mundane aspects of their day. ${ }^{428}$

This relationship between anime/manga series, shrines, and temples has even inspired the creation of companies, like the Seichi Kaigi Company, that specialize in anime pilgrimages and tourism. ${ }^{429}$ Seichi Kaigi publishes Seichi Kaigi, a magazine that covers tourism and anime pilgrimages. The magazine Niponica, published by the Ministry of Foreign Affairs of Japan, has highlighted the growth of anime pilgrimages in Japan in its 2017 special issue. The article examines the 2015 anime series Wake Up, Girls!, which is set in Sendai about a group of high school girls becoming a pop idol group. The article claims that one pleasure of the pilgrimage is being able "to cross the line between reality and fiction." 430 The article uses the term “聖地” (seichi) with the same religious connotations as a religious pilgrimage. There is even a map provided that depicts some manga and anime sites of note. ${ }^{431}$ Another site listed in the magazine is the Ōmi Shrine in Ōtsu, Shiga Prefecture, Japan. This shrine is associated with the anime (2011) and manga (2007) series Chihayafuru. ${ }^{432}$ The series tells the story of a high school girl, Chihaya Ayase, who wants to become the world's best karuta, a traditional Japanese card game, player.

427 “聖地巡礼,” Twitter Search, n.d. Web, 7 Aug 2017. $<$ https://twitter.com/search?q=\%E8\%81\%96\%E5\%9C\%B0\%E5\%B7\%A1\%E7\%A4\%BC\&src=typd $>$ 428 ナべ(11nabe2013), “今日は、仕事の疲労と今月は出費が多いので休養！でも、家の用を済まし たあとに自宅から 1 番近いタワーレコードアリオ熟宮店へ行きました。そのあとは、熟宮神社に 行って聖地巡礼してきました,” 4 Dec 2016, 4:14 a.m., Tweet.

${ }^{429}$ These tours visit not only shrines and temples, but other locations that are found in anime and manga. They use the Japanese word "seichi" which is not being used in a secular way as one might use pilgrimage in the West.

${ }^{430}$ Shundo Kaziaki, "Between Reality and Fiction: Anime Pilgrimage to a Special Place in the Heart," Niponica, 31 Mar 2017, 18.

${ }^{431}$ See Appendix Figure 4.7.

${ }^{432}$ Shundo Kaziaki, "Between Reality and Fiction: Anime Pilgrimage to a Special Place in the Heart," 20. 
According to religious historian, Joseph M. Kitagawa, one of the three types of pilgrimages, was a "pilgrimage to sacred places based on the faith in certain charismatic holy men who are believed to have hallowed those places by their visits.. ${ }^{, 43}$ People who originally visited these shrines were "motivated not by the desire to undergo ascetic practices but by people's devotion to a certain Buddha, Bodhisattva, or Kami, to whom the pilgrims pay homage, offer thanksgiving or ask for special favors. ${ }^{434}$ Similarly, otaku now go on pilgrimages to the shrine to experience and visit the same place their beloved pop culture figure has been. As witnessed and seen with the otaku who visited the Washinomiya Shrine, taking pictures of the torii featured in the opening of Lucky $\leftleftarrows$ Star. As outlined earlier, the Turners argued that pilgrimage sites have several common factors, particularly that "they are believed to be places where miracles happened, still happen, and may happen again"-a place that contains objects of the past. ${ }^{435}$ The otaku also journey to the place, a space pregnant with possibility. For instance, the otaku visits these shrines where his pop culture figure also visited, although she exists in a virtual or imagined space rather than the actual world. The distance between past and present spoken of by Turner serves the same purpose as the distance between the imagined time of the narratives and the real time that the otaku are living and experiencing. In both of these instances, the "distance" between the two times is removed through the act of pilgrimage. It is also at these pilgrimage sites that the otaku purchase and decorate or illustrate their wishes on a wooden tablet—wishes that would indeed take

\footnotetext{
${ }^{433}$ Joseph M. Kitagawa describes the three types of pilgrimage as 1) pilgrimage to the sacred mountain, 2) pilgrimages based on faith in certain divinities, and 3) pilgrimage based on faith in charismatic persons. See Joseph M. Kitagawa, "Three Types of Pilgrimages in Japan," Experience of the Sacred, Eds. Sumner Twiss and Walter Cosner, Hanover: University Press of New England, 1992, 179.

${ }^{434}$ Joseph M. Kitagawa, "Three Types of Pilgrimages in Japan,” 181-182.

${ }^{435}$ Victor Turner and Edith Turner, Image and Pilgrimage in Christian Culture: Anthropological Perspectives, xv, 6 .
} 
a miracle to be answered.

For the otaku, visiting the shrine allows him to be close to the pop culture figure. Their visit also reflects a sense of community, as evidenced by the otaku posting to social media about their visits. Japanese popular culture has helped alleviate the anxieties of youth in Japan, especially those growing up after the burst of the economic bubble in the 1990s. Considering the current recession in Japan, the poor prospects for jobs, the pressures of school and society, and other pressures faced by otaku, it should come as no surprise that otaku, like most people, take a certain solace in pop culture to alleviate anxieties the Japanese have about the future. ${ }^{436}$ Thus, the otaku is not only visiting a pilgrimage site to be nearer to his pop culture figure, but he is also experiencing a release from the stressful world that he must navigate when not engaged in his interests. The otaku's engagement in consumption of popular culture shares similarities with the two types of pilgrims the Turners discuss. Again, speaking of Christian pilgrims, the Turners claim:

"While the pilgrim seeks temporary release from the
structures that normally bind him, the tribal initiand seeks a
deeper commitment to the structural life of his community,
ultimately, in many cases, to the state of being a venerated,
legitimate ancestor after death, rather than a homeless
ghost. Of course, historically the distinction has not always
been so clear-cut. Pilgrims sometimes enhance their
mundane status through having made the journey. And in
tribal religions, certain kinds of initiation [...] offer a
measure of release from the duties and necessities of the
structural order, and a measure of participation in the
invisible milieu of the gods or ancestors.., 437

The otaku shares elements of both the Western pilgrim and the "tribal initiand." The

\footnotetext{
${ }^{436}$ See William M. Tsutsui, Japanese Popular Culture and Globalization, Ann Arbor: Association for Asian Studies, Inc., 2010.

${ }^{437}$ Victor Turner and Edith Turner, Image and Pilgrimage in Christian Culture: Anthropological Perspectives, 9.
} 
otaku visits these places and is transported from reality to a space in which he is closer to his pop culture figure, with the performance of cosplay heightening this feeling. The otaku is initiated into Shintō from birth, despite the fact that the otaku may never consider himself to be an adherent of Shintō. The otaku's name is registered within a shrine when he is born, making him an ujiko, or shrine parishioner, of that particular shrine, whether he wants to be or not. ${ }^{438}$ After his death, he becomes an ujikami, "an ancestor," one of many, just as the tribal initiand becomes a "legitimate ancestor."

The otaku legitimates his status among other otaku by posting photos of his pilgrimage, showing that he is knowledgeable of the pilgrimage sites and can afford to travel to such locations. ${ }^{439}$ For the otaku, pilgrimage is just one part of their behaviors. As this is a relatively young phenomenon, this chapter closely examines the Washinomiya Shrine and the Kanda Shrine as they represent a shift in the involvement of the shrines with this phenomenon. ${ }^{440}$ The otaku's visit to these sites can be for purposes related to their pop culture figure, and also for religious practice, as it happens that these sites are historically recognized as sacred sites while the otaku are giving their patronage to them. By incorporating these religious elements and refashioning pilgrimage for themselves, and as a consequence of that, the Shintō shrines and Buddhist temples are taking notice and incorporating popular culture into the shrines and temples. These Shintō elements are

\footnotetext{
${ }^{438}$ The term can also be translated as "clan child." See Chapter Two, Section III.1 for information on ujiko. ${ }^{439}$ See Appendix B where the several otaku visiting the Washinomiya Shrine were taking photos of the shrine's Torii as well as closely examining the ema located on the shrine grounds, in between the entrance and gift shop.

${ }^{440}$ While the Ryōhō-ji Temple, a Buddhist temple, has created an anime mascot, there does not appear to be the same large number of otaku who visit this site because of their mascot. The Washinomiya Shrine and Kanda Shrine are associated with two anime that have proven to be popular with fans. As a result, the shrines reflect the particular fans that visit the shrines by incorporating elements associated with the anime. There are themed portable shrines, as in the case of Lucky 2 Star, or the shrines promote the characters to an official mascot position and sell wooden tablets featuring the characters on them, as in the case of Love Live!.
} 
being incorporated into the otaku fandom's behaviors and practices. The response of Shintō shrines to this phenomenon will be illustrated below.

\subsection{OBSERVATIONS AT THE WASHINOMIYA SHRINE ${ }^{441}$}

During my own visit to the Washinomiya Shrine in June 16, 2016, there were five otaku that I observed visiting the site despite it being overcast and rainy. The young men I observed appeared to be otaku due to their style of dress and reactions to the ita-ema, an ema tablet decorated with fan art. The first two otaku stood out compared to the other shrine visitors who were well-dressed and solemn in their behaviors. They resembled some of the otaku I had seen in Akihabara, carrying bulging backpacks and dressing in no way as fashionably as the non-otaku I had seen in Japan.

The otaku immediately stopped in the parking lot of the shrine and took a photo of the torii, the gate that marks the entrance of the shrine. The torii is prominently featured in the opening of the Lucky $\lesssim$ Star anime. They were visibly excited about the shrine and appeared to be on an anime pilgrimage. Once they walked past the torii, they immediately headed over to the tree surrounded by ema, reading and closely examining each one. Every now and then they laughed at the tablets and pointed to them. When one of the miko, or shrine priestesses, walked from the gift shop area to one of the nearby buildings, the otaku became very excited and the larger of the two otaku tried taking a photo of her. As they walked further into the shrine grounds, I noticed another young man approach the torii. He was dressed similar to the other two, in clothes that were slightly oversized and wrinkled. I watched him remove some of his key chains and pull out a camera. He also took pictures of the torii and smiled the whole time he was doing it.

${ }^{441}$ For this section, please refer to Appendix B, June 16, 2017 entry. 
Similar to the other two young men, he immediately headed to the ema tablets. I observed his reactions as he smiled, chuckled, and even frowned at some of them. After browsing the racks, he visited the gift shop area and purchased an ema. When I approached him, he was reluctant to talk with me but confirmed his interest in Lucky $\lesssim$ Star and his favorite character. I assumed that the ema he purchased was for the purposes of creating an ita-ema but he excused himself and left before I could confirm his intentions. The gift shop did not sell Lucky 2 Star themed ema and it was often difficult to get interviews with both otaku and non-otaku, especially as a foreigner. Even as I left the shrine, three more young men passed me, talking about the shrine and pointing to it excitedly when it came into view.

\section{SHOPPING AND SPENDING}

In Japan, the line between the secular and sacred is often blurred, especially where capitalism and religion are concerned. Similar to Weber's capitalist Protestants, the otaku practice a form of asceticism while being active in a modern world. The goal of asceticism for these Protestants was "to be able to lead a watchful, aware, alert life" that eradicated "uninhibited indulgence in instinctive pleasure." ${ }^{442}$ The otaku do not attempt to eradicate indulgence in instinctive pleasure, as they seem to be seeking a constant state of instinctive pleasure with their pop culture figure and consumed pop products. Rational asceticism, as practiced by the Protestants, brought order into the conduct of life of the people who practiced it. For the otaku, it could be said that rational asceticism brings order to their lives by allowing them to focus their energies in pursuit of their pop culture figure.

${ }^{442}$ Max Weber, The Protestant Ethic, 81. 
The otaku are viewed as self-absorbed, self-indulgent, and socially absent by nonotaku, the type of people similarly abhorred by Weber's Protestants. Weber argued that the meanings that were imposed on beliefs and values, by culture and people, were influenced by the manner with which they perceived their own reality and how they acted, or reacted, within those realities. ${ }^{443}$ For the Protestants, their behaviors resulted from religious ideologies that they internalized and directed towards their daily activities. The otaku have similarly taken religious elements and aspects of Japanese cultural tradition, internalizing them and directing them towards their daily activities. The Protestants focused on work as a means of providing meaning to one's life and to curtail temptation. The otaku are self-indulgent and spend their money on things that the Protestants would have viewed as forms of empty enjoyment, but they are also avoiding certain temptations. Rather than hedonism with flesh and blood women, the otaku are focused on fictional women. Outside of their interests and hobbies, money is saved, not as a means of the Protestant ethic signaling God's graces, but as a means of giving reverence to their beloved pop culture figure.

According to Weber, people that labored in their calling were doing what God ordained; they were fulfilling the opportunities given to them. Asceticism itself exists in opposition to frivolous activities that could lead one away from work in their calling and from religion. For the otaku, their behaviors and practices could be considered "frivolous activities," however, these activities are linked to religious-like traditions despite the insistence that the Japanese are non-religious. Otaku have seemingly even reformulated asceticism, as rather than avoiding "frivolous activities," they seem to indulge in them as a form of worship. Consumption of pop culture and devotion to their pop culture figure is

${ }^{443}$ See Chapter 5 of Max Weber, The Protestant Ethic. 
a part of their calling. Weber claims, "that powerful tendency toward uniformity of lifestyle, which today is encouraged by the capitalist interest in the 'standardization' of production, has its spiritual [ideell] basis in the rejection of the 'worship of the creature." "444 The otaku can be considered uniform in their lifestyle, as evidenced through their dress and preoccupation with their interests. Similarly, the Puritans avoided spending money on any activity that did not further serving God's glory, a means of rejecting creature-worship. ${ }^{445}$ Otaku spend money to support the creators and companies associated with their pop culture figure. It could be argued that the otaku spend money for self-gratification, but this point will be further elaborated below. Instead of spending their money, the Puritans saved it, increasing their money and wealth. Pursuing wealth, being greedy, and spending money on entertainment were bad, but earning money through one's labor was considered a sign of God's blessing upon the individual. In the eyes of non-otaku, spending most of one's money on pop culture products is considered bad, but the otaku's collection of pop culture products signify a devotion to the pop culture figure that is recognizable by other otaku.

At first glance, one could say that the otaku do not perform the rational asceticism Weber understands the Puritans to have done. They spend their money on items largely associated with entertainment and lacking depth or value, as pop culture is both disposable and not often well-regarded. Upon closer inspection, the otaku do not spend their money, aside from items that are necessary for living in Japan (i.e. transportation, food, etc.) unless it is on items associated with their pop culture figure. Otaku that were observed in Akihabara were often spending money in the arcades, visiting maid cafes, or

\footnotetext{
${ }^{444}$ Max Weber, The Protestant Ethic, 114.

${ }^{445}$ Max Weber, The Protestant Ethic, 114-116.
} 
examining and purchasing figurines ranging from $¥ 4000$ (roughly $\$ 40$ ) and up. ${ }^{446}$ Money earned, whether through actual labor at a job or from a parent who supports them financially, is given to the companies and creators of their favorite series. As far as the otaku are concerned, they are not wasting their money on frivolities; rather they are supporting their pop culture figure, who will potentially provide, or "bless," the otaku with happiness. One otaku in Nara discussed how happy Nico, a female character, from Love Live! made him feel. He said, "She's happy. She makes me happy!” while holding his hands and tilting his head in the same signature pose that Nico is known for. ${ }^{447}$ The otaku saves their money and time for their pop culture figure while navigating a nonotaku world, engaging in what could be considered a form of rational asceticism-one that is focused solely on living a life immersed in devotion to their pop culture figure.

By purchasing these themed items, the otaku are supporting and building a relationship with the pop culture figure. They spend their money willingly and readily on products associated with the pop culture figure, but will spend thriftily on themselves. In A Theory of Shopping, Daniel Miller argues that shopping is a form of sacrifice performed by the shopper for a desiring subject. Shopping "expresses a relationship between the shopper and a particular other individual such as a child or partner, either in the household, desired or imagined. ${ }^{448}$ In this case, the otaku is the shopper who purchases items that support the pop culture figure (the desiring subject they have created). The otaku possess a disposable income, do not need to support a family, and may not even have a girlfriend to purchase gifts for. Instead, they spend money on the

\footnotetext{
${ }^{446}$ Maid cafés vary in prices, with drinks ranging from $¥ 530$ and entrées from $¥ 1030$. See Appendix B for observations of otaku in Akihabara.

${ }^{447}$ Personal Interview. Nara, Japan. 30 May 2016.

${ }^{448}$ Daniel Miller, A Theory of Shopping, New York: Cornell University Press, 1998, 12.
} 
object of their devotion — the pop culture figure.

According to Miller, the act of shopping for others can be a form of altruistic devotion to something, but he was discussing real people, not imaginary characters. The otaku are shopping as an act of devotion, but it is not directed necessarily at a real person. The world sees the otaku as excessive consumers, but when considering the otaku mindset, the otaku are shopping in an act of devotion although it contradictorily appears to be for self-gratification. Miller also claims that shopping is "a relationship to a more general goal which transcends any immediate utility and is best understood as cosmological in that it takes the form of neither subject nor object but of the values to which people wish to dedicate themselves. ${ }^{449}$ Similarly, the otaku's relationship to the pop culture figure is one in which the otaku have dedicated themselves.

Most otaku I observed in Akihabara or at the chain store Animate appeared to be relaxed and happy while they purchased or browsed items. When conducting his fieldwork in London, Miller found that individuals who live alone and are lonely dislike shopping and see it as an inconvenience, but change when it comes to buying something with a friend or for a pet. He points out, "An inability to relate to people usually means an inability to relate to goods also." ${ }^{, 450}$ The lonely are more obsessed with relationships than people who have relationships and take them for granted. ${ }^{451}$ So, according to Miller, shopping is enjoyable when it is for the family or a loved one. In the case of the otaku, they too could be considered lonely people, not unlike the elderly and professional women that Miller interviewed. However, the otaku purchase items to please a twodimensional character rather than an actual human being like those in Miller's study.

\footnotetext{
${ }^{449}$ Daniel Miller, A Theory of Shopping, 12.

${ }^{450}$ Daniel Miller, $A$ Theory of Shopping, 34.

${ }^{451}$ Daniel Miller, $A$ Theory of Shopping, 34.
} 
Miller did not seem to have considered this phenomenon during his research focusing on shoppers in North London. The otaku's relationship to the goods is important because the goods reflect the two-dimensional character.

Otaku are not usually found in trendy shopping districts, wearing fashionable clothes, or consuming any luxury or trendy commodities; rather that they dislike shopping unless it is in Akihabara or similarly 'nerdy' districts, and only when they are shopping for items related to their pop culture figure or hobbies. In a roundtable discussion by scholars who consider themselves to be close to the otaku, they argue that otaku "reject the physical" and are "socially inept." ${ }^{452}$ One of the scholars, Kaichiro Morikawa even stated, "Otaku are self-conscious about being condescended to, when they go to fashionable places like Shibuya. But they feel safe in Akihabara, because they know they'll be surrounded by people who share their quirks and tastes." ${ }^{453}$

While visiting Tokyo, including stops in shopping districts Shibuya and Harajuku, there were no Japanese who stood out as otaku. Everyone was dressed in current fashions or wearing clothes specific to the numerous Japanese subculture fashions, like Harajuku style or Hip Hop. However, in 2016 during my trip to Akihabara, the so-called Mecca of otaku, I observed many otaku. Anyone dressed in business attire or current fashion trends stood out. According to some Japanese research sites like Mobile Marketing Data Laboratory and Goo Research, Japanese can tell an otaku because of their bags from otaku shops such as Animate or Tora no Ana. Alternatively, one can spot an otaku by their style, by their backpack covered in anime badges, their signature style of wearing their backpack over both shoulders, and what could be considered other incidental

\footnotetext{
${ }^{452}$ Toshio Okada and Kaichiro Morikawa, "Otaku Talk."

${ }^{453}$ Toshio Okada and Kaichiro Morikawa, "Otaku Talk."
} 
stereotypes. ${ }^{454}$ They are more concerned with their hobbies and pop culture figures than keeping up with fashion trends. Many otaku shop online or support stores that specialize in anime and manga in large numbers. As evidenced by photos of otaku rooms and their images posted to social media of "celebrating" with their objects of devotion. The pop culture figure is treated with care, and the otaku show their devotion to the pop culture figure through their money and devotional energy.

At the center of otaku practices and behaviors is a focus on their collections of pop products. As has been mentioned, otaku are known for their obsessive collections of popular culture. Despite others who may also collect similar items, have similar desires, and maybe similar tastes, the otaku are unique in the way they pursue items for their collections. The act of collecting is solitary, "based on an exclusive and exclusionary relationship between subject and object." ${ }^{255}$ The otaku are typically solitary in actual life despite being actively engaged online in message board and online communities, attending anime or manga conventions, otaku centered shopping spaces, or specially themed events. ${ }^{456}$ Whenever I observed otaku in public in June 2016, many were often alone or never in groups of more than two or three people. ${ }^{457}$ The relationships they may have with other otaku vary from supportive to antagonistic. For instance, they may experience contempt, jealousy, and so on, as they post pictures of their collections online as well as even providing critiques of the collections of others. Ultimately, however, the

454 「オタクっぽい」と感じてしまう男性の格好ランキング, Goo Ranking, Goo Research, 11 Jan 2008, Web, 13 Sep 2016. <https://ranking.goo.ne.jp/ranking/category/026/otaku_fashion_male/>; See also オタラボ調査、「あの人オタクかも?と思ってしまう行動アンケート」調査結果公開/株式会社 ビジュアルワークス, MMD, Mobile Marketing Data LABO, 21 Jun 2010, Web, 14 Sep 2016.

$<$ https://mmdlabo.jp/press_release/detail_536.html>

${ }^{455}$ Hosokawa and Matsuoka, "Vinyl Record Collecting as Material Practice," 164.

${ }^{456}$ See Appendix B, many otaku were either alone or in small groups, typically of no more than three people.

${ }^{457}$ Refer to Appendix B. 
otaku are connected "through the objects they possess and those they seek to possess." 458 They engage in dialogue about their collections and even provide advice on how to obtain these objects. These objects create a community by organizing people around them via a certain charisma that emanates from these objects, typically in the form of cuteness (kawaii) or moe.

In their practices, some otaku try and occupy the same space as their pop culture figure. One way this is achieved is through the purchase of material goods that depict or otherwise embody and/or represent their pop culture figure. One such item is the pillowcase that can be fitted on a body pillow or inflatable pillow, known as a dakimakura, which features a life-size figure of an anime character on both sides. ${ }^{459}$ Several shops I visited in Akihabara sold these pillowcases close to the registers, with signs asking patrons to not take photos. The figure can be a male or female, but most often the dakimakura depicts a female anime character or actress. On one side, the figure is depicted as fully clothed but appears shy and blushing. On the other side, the figure is depicted fully or partially nude in a suggestive pose. This figure's facial expressions and blush, retain the aspect of shyness, mixed with an expression of pleasure. While the depiction of these characters points to an assumption that these products are used for masturbatory practices, they were also often featured in claw machine games that sold sex toys for male masturbation. These toys were also themed according to various female anime figures as well. Many anime and manga series characters have been featured on body pillows, typically female characters, for purchase and possession by anime fans.

\footnotetext{
${ }^{458}$ Hosokawa and Matsuoka, "Vinyl Record Collecting as Material Practice," 164.

${ }^{459}$ These body pillows are not just limited to two-dimensional figures, but can also depict realistic women, such as Adult Video (AV) idols (porn stars). See Appendix A Figure 4.10.
} 
The figures are often drawn in a style that reflects the moe aesthetic. ${ }^{460}$

\section{ESTABLISHING SPACE AND INTIMACY}

An examination of the role of fandom is critical for an understanding of how the otaku have influenced certain societal aspects, such as the economy, in Japan. The otaku are a type of fan in Japan known for their compulsive focus on their object(s) of interest. Despite their obsessive behavior directed at their figurines and pop culture products, the otaku and other Japanese fans still show a modicum of propriety when it comes to the human authors, writers, and artists who create anime and manga series and pop music idols, actresses, other celebrities. William W. Kelly describes Japanese fandom as being:

"a gesture of intimacy toward commodified culture, but our studies also show clearly that such intimacy is not to be confused with identity. For several reasons, fans are often involved in an intense play between identifying and distancing. For instance, keeping a certain social and physical distance is sometimes an acknowledgment of propriety. [...] but other fans - the manga costume players and amateur manga artists, for example - may be able to play with their imagination only by maintaining a gap with the source of inspiration." 461

The otaku practice a certain social and physical distance in relation to the actresses that voice their beloved characters. Additionally, the may sometimes create fan made works, such as comics, that allow them to interact with their pop culture figure in an imagined space, one removed from a physical proximity which is impossible. ${ }^{462}$

This practice of preserving a certain physical or social distance between fan and

\footnotetext{
${ }^{460}$ See Appendix A Figure 4.11.

${ }^{461}$ William W. Kelly, "Introduction: Locating the Fans," 10.

${ }^{462}$ See William W. Kelly, "Introduction: Locating the Fans," Fanning the Flames: Fans and Consumer Culture in Culture in Contemporary Japan, Ed. William W. Kelly, Albany: State University of New York Press, 2004, 1-16.
} 
certain celebrities or a pop music idol, known as a "pop idol," once observed between the emperor god and those wishing to speak with him. When the Emperor was considered to be a living deity, distance and a screen separated those who wished to speak to him. Thus, there is a similarity with a direct trajectory preserving traditional practice as evidenced by the behaviors of fans who maintain an imagined distance from their favorite pop idols and other celebrities.

Some otaku will follow the voice actresses of their favorite anime characters on social media and see them at events, they still maintain a proper distance from them. For instance, there are some events in which the voice actresses can speak directly to fans in person, much like events in America, such as Comic-Con, where the actors are on a stage and a constructed space separates the celebrity from the fans. ${ }^{464}$ There may also be an opportunity for the otaku to occupy the same space as the voice actress for photos, but the otaku do not always directly touch the celebrity outside what is deemed "appropriate" by the event organizers. On some occasions, either the voice actress or in some cases, pop idol, lean away from the otaku, but typically the otaku adhere to an unspoken rule to not overstep propriety with the celebrity. ${ }^{465}$ Fans observe similar distances when meeting movie stars, athletes, singers, and other celebrities. However, there are certain times where they might touch the star's hand as seen with the handshaking events that are held for pop idols.

\footnotetext{
${ }^{463}$ Refer to Chapter One footnote explaining the word アイドル [aidoru].

${ }^{464}$ See Brian Ashcroft and Shoko Ueda, Japanese Schoolgirl Confidential: How Teenage Girls Made a Nation Cool, Rutland: Tuttle Publishing, 2014.

${ }^{465}$ See Casey Baseel, "Japanese Idol Singers Put on Hazmat Suits Before Hugging Fans at Tokyo Event," Rocket News 24, 8 May 2017, Web, 18 Nov 2017. <https://en.rocketnews24.com/2017/05/08/japanese-idolsingers-put-on-hazmat-suits-before-hugging-fans-at-tokyo-event $\% \mathrm{E} 3 \% 80 \% 90$ video-photos $\% \mathrm{E} 3 \% 80 \% 91 />$ See also, Casey Baseel, “Japanese Idol Singer Has an Important Request for Fans: Please Use Deodorant," Rocket News 24, 21 Aug 2017, Web, 18 Nov 2017. <https://en.rocketnews24.com/2017/08/21/japaneseidol-singer-has-an-important-request-for-fans-please-use-deodorant/>
} 


\section{COSPLAY}

Although the otaku cannot place the voice actress in imaginary situations (as she is a real person), when it comes to the non-human two-dimensional figures of their favorite anime characters, they may use their imagination to engage with the character in fan-made comics or by wearing cross-gender costumes. "Cosplayers" are individuals who will dress as their favorite pop culture media characters. Cosplay, the shortening of "costume play," is a popular activity not limited to Japan, in which fans will dress up as their favorite characters or even invent new characters. ${ }^{466}$ Cosplayers often pose for pictures, take on the mannerisms of their assumed character, and are often found at conventions, although some will wear their costumes to various sites associated with a place in which their character "exists" or has visited. ${ }^{467}$

Performances in costume allows cosplayers to be close to their objects of affection-especially considering the shifting of gender. Male cosplayers at the Washinomiya shrine have been known to wear the costumes of the high school girls from Lucky is Star. ${ }^{468}$ These cosplayers wear wigs, skirts, and pose around the city of Kuki to recreate scenes from the series. Their actions are two-fold as they are engaging the same space as their favorite characters while imitating the actions and behaviors of their pop culture figure.

Cosplayers are mimicking established tradition and ritual custom where Shintō legends are acted out at shrines by costumed actors. A parallel to these actions would be the devotees visiting Shintō shrines specific to certain kami so that they could ask for

\footnotetext{
${ }^{466}$ Ian Condry, The Soul of Anime, 25.

${ }^{467}$ Ian Condry, The Soul of Anime, 25.

${ }^{468}$ See Hiroyuki Watanabe, "The Nerdiest Shrine in Japan," translated by Lena Oishi, Vice, 26 Jan 2010 , Web, 25 Sep 2016.
} 
boons or blessings that were specific to that kami, or certain Bodhisattvas at Buddhist temples — being in the presence or vicinity associated with a certain kami or Bodhisattva. This could be related to Eliade's discussion of actions being influenced by and imitative of the gods. ${ }^{469}$ Eliade argues that psychological actions held significance for religious man, while actions for non-religious man were without spiritual significance and thus desacralized. ${ }^{470}$ However, this modern phenomenon of otaku and cosplay appear to be reminiscent of the actions by religious man despite being set in a modern and supposedly secularized world. Their actions appear to hold some significance, possibly spiritual. Many shrines and temples have performances, such as the kagura, which derives from the legend of Amaterasu retreating into a cave. ${ }^{471}$ The dance imitates the dance that Ameno-Uzume performed to lure the sun kami out of her cave and to restore light to the world. There are also many other types of kagura that are performed, complete with special costumes and movements referencing folklore, history, and the kami themselves. ${ }^{472}$

\section{DEVOTIONAL-LIKE PRACTICES}

The pop culture figure blends pop culture made into a consumable and disposable object of focus for the otaku. These figurines are made of plastic, and otaku can have several they are devoted to at once, or can at any time dispose of them and replace them with a new pop culture figure. The pop culture figure itself is like an empty vessel,

\footnotetext{
${ }^{469}$ Mircea Eliade, The Sacred and the Profane, 47-51.

${ }^{470}$ Mircea Eliade, The Sacred and the Profane, 168.

471 This legend is recounted in both the Kojiki and the Nihongi. Amaterasu's brother Susanō played a prank on her and she became so frightened that she hid herself in a cave. The other kami tried many things to lure her out, but the kami of dance, Ame-no-Uzume turned over a tub and began to dance on it. The other kami enjoyed her performance and upon hearing their revelry, Amaterasu peeked out of the cave and exited. This is an important legend because it also provides the background for the Three Imperial Regalia.

${ }^{472}$ See David Petersen, Invitation to Kagura: Hidden Gem of the Traditional Japanese Performing Arts, Morrisville: Lulu Press, 2007.
} 
interchangeable and changing based on the whims of the otaku. The otaku are using Shintō and Buddhist religious elements, particularly in ritual-like practices. The figures are treated like a shintai, or kami body, that are enshrined inside of the kamidana, or household shrine, in Shintō practice. ${ }^{473}$ The shintai is kept clean and pure, placed within the kamidana ${ }^{474}$ Rather than being wrapped up and hidden away like a traditional shintai, however, the plastic action figures or figurines are lovingly displayed around one's computer monitor or television, to be seen and present at all times. Shintō itself did not originally have a strongly defined visual culture and any images of the kami were inspired by Buddhist religious art. ${ }^{475}$ Otaku culture is rooted in visual culture and having the figurines and images placed around their rooms gives life to a tangible source instead of an ambiguous deity. Aside from some otaku having sexual desires for the pop culture figure, the otaku perform Shintō and Buddhist-like rituals of food offerings, levels of respect for the figurines, and celebrating days associated with the pop culture figure.

The organization and structure of these shrine-like displays appear to be somewhat self-conscious on the part of the otaku, although the otaku may not immediately identify these actions as religious. ${ }^{476}$ Both the kamidana and the otaku's space are typically kept clean and organized. While it is not a daily practice that one may see with Shintō and Buddhist worship at the home shrine or altar where daily offerings of incense and food are proffered, the otaku do present food offerings to these figures on

\footnotetext{
${ }^{473}$ Brian Bocking, A Popular Dictionary of Shintō, 172-176.

${ }^{474}$ Brian Bocking, A Popular Dictionary of Shintō, 172.

${ }^{475}$ Sampa Biswas, Indian influence on the Art of Japan, New Delhi: Northern Book Centre, 2010, 95. See also Sachiko Tamashige, "Seeing Where Shintō and Buddhism Cross," The Japan Times, 16 May 2013, Web, 19 Nov 2017. <https://www.japantimes.co.jp/culture/2013/05/16/arts/seeing-where-shinto-andbuddhism-cross/\#.WhH1HhNSyRs>

${ }^{476}$ It should be noted again that the Japanese are not quick to claim anything is religious and they typically consider themselves non-religious (mushükyō). For various theories and perspectives see Toshimaro Ama, Why Are the Japanese Non-Religious?: Japanese Spirituality: Being Non-Religious in a Religious Culture, Lanham: University Press of America, 2005.
} 
certain dates that are important to the otaku or the figure itself, namely her birthday and Christmas. $^{477}$

During Christmas or Valentine's Day in Japan, days often assumed to be special times for couples spending time together, some otaku will purchase cakes and place them in front of their computer monitors or televisions. ${ }^{478}$ Some otaku will purchase smalldecorated cakes and set them in front of an electronic image of their pop culture figure in a sacrificial type manner. These otaku may light small candles, arrange figurines of the pop culture figure around the monitor or television depicting the electronic image, and place other food offerings before the image of their beloved pop culture figure much like those devotional offerings seen with kamidana in Japan or bhakti devotion. ${ }^{479}$ The otaku's behaviors are a melding of emotional and devotional practices, creating something entirely new. For example, one anonymous user posted an image of his Christmas Eve dinner with his "wife" to the blog LiveDoor. The user was a fan of the 2010 anime Kei-On!, and his monitor displays an image of the five high school girls, with five figurines placed in front of it, as well as a candle in front of each figurine.

Surrounding that is a collection of a Christmas cake, popularly sold in Japan during Christmas, and other food dishes. The image was one of many posted in three-part posts on LiveDoor of other otaku who posted their own similar images across various message

\footnotetext{
${ }^{477}$ As has been mentioned, Christmas is typically seen as a time for couples in Japan rather than a celebration of the birth of Jesus Christ.

${ }^{478}$ See Appendix A Figure 4.12, which depicts characters from K-On! during Christmas, surrounded by food, lights, and so on.

479 The otaku's behaviors and practices have parallels to bhakti, which is characterized by devotees making ritual offerings to the Hindu deities, using images or idols, which represent the body of a specific deity. $P \bar{u} j \bar{a}$ is a part of bhakti devotional practices that focus on one particular Hindu deity rather than the entire Hindu pantheon. It also consists of ritual prayer and can be performed at home or at a temple. The major difference between the otaku and the Hindu devotee, is that that the Hindu devotee does have sexual attachment or desires towards the Hindu deity. See Joyce Burkhalter Fluekiger, "Loving and Serving God: Bhakti, Murtis, and Puja," Everyday Hinduism, West Sussex: Wiley-Blackwell, 2015; and Vineeta Sinha, Religion and Commodification: 'Merchandizing' Diasporic Hinduism, New York: Routledge, 2011.
} 
boards and social media. ${ }^{480}$

Additionally, the pop culture figure's birthday is similarly celebrated by buying a cake or other offerings for the figure. ${ }^{481}$ One Twitter user, posted their own images to social media to show how they celebrated one Love Live! character's birthday. The tweet reads, "Happy Birthday Umi-chan! I will continue to love you in the future."482 The otaku's arrangement is missing the common electronic image, but has a framed image of the animated character at the center of their shrine-like arrangement, as well as a cake bearing her image. Numerous figurines and action figures surround images, both framed and not, as well as other items associated with the pop culture figure.

These practices seem to be uniform within the otaku community, despite not all otaku being devoted to the same characters or series. The monitor or television screen displays the pop culture figure to which they are devoted; they show this devotion through the purchase of products that bear the character's likeness, by watching or reading the series in which she is featured, and creating art, such as fanmade comics that feature her. In traditional Shintō practice, one places the kamidana in their home, which has a specific kami enshrined. Inside of this mini-shrine is a shintai, which can be literally translated as the "body of the kami." Small offerings, such as fruits or cups of sake, are placed before the kamidana and the family may pray to it at any time. The otaku's behaviors with their pop culture figure is similar, although they may not pray to her, and instead show their devotion through acts of consumerism - purchasing figurines,

\footnotetext{
480 “年クリスマス・イヴ（24 日）嫁との晚餐まとめその 3 .”LiveDoor Blog, 25 Dec 2011, Web, 29 Sep 2016. $<$ http://ceron.jp/url/blog.livedoor.jp/insidears/archives/52514190.html>

${ }^{481}$ See Appendix A Figure 4.13, which depicts one otaku celebrating the birthday of Sonoda Umi, a character from Love Live!

${ }^{482}$ Azalea (Azalea01606534). “海未ちゃん誕生日おめでとう!!!俺はこれからも、君を愛し続けてい くよ [Happy Birthday Umi-chan! I will continue to love you in the future].” 14 Mar 2016, 8:00 a.m, Tweet.
} 
video games, and other pop culture products associated with the pop culture figure, to an image or figure that the devotee is revering. ${ }^{483}$

Many religions can be considered to share similarities when it comes to devotional practices. In the case of the otaku's behaviors and devotional practices, there are some parallels to the devotional practices in Hinduism and Buddhism. Rather than being devoted to a Hindu deity as found in bhakti, a devotee in Buddhism participating in pujjā will make personal devotions to the Buddha, typically an image of the Buddha, and they will recite a variety of chants that refer to taking refuge in the Three Jewels and the Five Precepts. ${ }^{484}$ The Buddhist form of $p \bar{u} j \bar{a}$ is performed daily at home rather than at a temple. In Modern day Japan, many households still have kamidana or butsudan. ${ }^{485}$

These miniature shrines and practices share some similar elements to bhakti devotional practices found in India, as Shintō practitioners will leave offerings of incense, fruit, flowers, among other things during their daily prayers. ${ }^{486}$ A large difference is that Shintō and Buddhist devotees do not typically have an intense personal and emotional relationship to the kami they are praying to as Hindu devotees often have. ${ }^{487}$ The otaku will have an intense emotional and personal relationship to their pop culture figure. They blend elements from Shintō into their own form of devotional practices and behaviors,

\footnotetext{
${ }^{483}$ See Appendix A Figure 4.14, which depicts an image of puja during bhakti devotion.

${ }^{484}$ The Three Jewels refer to the sangha (the Buddhist community), dharma (the Buddha's teachings), and the Buddha. The Five Precepts are the vows taken by Buddhists practitioners: to abstain from killing, stealing, sexual misconduct, lying, and from intoxicants.

${ }^{485}$ Kamidana (literally "god shelf") are miniature shrines used to pray at for specific kami, see Appendix A Figure 4.15. The butsudan (literally "Buddhist altar") are similar to the kamidana, as they are miniature shrines found with icons of the Buddha or one of the many Bodhisattvas. Both are prayed at daily with small offerings, such as fruit, flowers, incense, and so on.

${ }^{486}$ Many modern Hindu practitioners use electronic puja in their devotional practices. As noted earlier, the otaku do something similar; however, rather than using holy days specific to the religion, they offer cakes and snacks to an image of their pop culture figure, sometimes with figurines of the beloved character surrounding the image.

${ }^{487}$ Karen Pechelis, "Bhakti Traditions," The Continuum Companion to Hindu Studies, Ed. Jessica Frazier, New York: Continuum Publishing, 2011, 107-121.
} 
which then add emotional dimensions.

The otaku, often noted for their expertise in electronics and computers ${ }^{488}$ in addition to their obsessions with their hobbies, use electronics for much of their devotion to the pop culture figure. Using a camera or the camera on their phone, the otaku take photos of their celebration with or dedications to their pop culture figure and then post them to Twitter. ${ }^{489}$ The otaku utilize the Internet to communicate with other otaku online via social media and message boards, as well as to keep up-to-date with information and news about their pop culture figure. They can use their mobile phones to watch videos or play video games associated with the anime or manga that features their pop culture figure.

The otaku will dedicate areas in their living space to construct miniature shrines to their pop culture figure. They may make their whole room into an altar of sorts, with posters, wall scrolls, figurines, and other products featuring their pop culture figure all over the room. One only needs to search the terms "otaku rooms" on the Internet to see numerous images, blogs, websites, and so on dedicated to these rooms. Vice Media, a source dedicated to culture and news topics, posted a video on their Vice Japan YouTube channel, in which they followed Japanese photographer Shiori Kawamoto, who specializes in photographing otaku's rooms as part of their “A Day With!” series. When talking about the otaku's rooms, Kawamoto says, “The aura just overwhelms you. Something comes over you. The atmosphere, the mood." ${ }^{490}$ He also notes how happy

\footnotetext{
${ }^{488}$ Miho Aida, "The Construction of Discourses on Otaku: The History of Subcultures from 1983 to 2005," 123-124.

${ }^{489}$ See Appendix A Figure 4.16, which depicts another birthday celebration to a character from Love Live! 490 “密着 24 時! 願望を突き詰めた部屋 - Otaku Room Photographer,” YouTube, uploaded by Vice Japan, 28 May 2014, https://www.youtube.com/watch?v=xIeB8caPjoA.
} 
they appear surrounded by the things they love. ${ }^{491}$ Images of these rooms depict desks with computers on them surrounded by a multitude of pop culture products. The location of these shrine-like arrangements are typically on a desk surrounding a television or a computer monitor. The shelves around the monitor are lined with products of the beloved pop culture figure, typically in the form of figurines. The otaku are near their pop culture figure as they work front of their computers, consuming pop media, and as they are doing other mundane tasks. Their backpacks, cellphones, and lighters may be adorned with images of their favorite character on the charms.

Some otaku spend money to turn their car into an itasha, or "painful car" which refers to the money and time spent decorating the vehicle. Those who turn their car into an itash $a$ also highlight the extent of the otaku's devotion to their pop culture figure. The itasha is a vehicle that is decorated with images of particular pop culture figures. ${ }^{492}$ The itasha bears some similarities to the mikoshi, the portable Shintō shrine that is used to transport the kami during matsuri, or festivals. ${ }^{493}$ During an autumn matsuri in Washinomiya, there is a Lucky $\lesssim$ Star mikoshi depicting the characters of the anime on it that is paraded through the streets, along with itasha ${ }^{494}$ While the car is not thought to actually house the pop culture figure, great care and money are invested in the construction, preparation, and maintenance of the vehicle. Similar to the mikoshi, the itasha is only shown off at special events, such as Comiket or motorsporting events. As the popularity of "otaku culture" grows, auto products increasingly reflect otaku sensibilities. GPS navigation systems are available with customizable voices from

\footnotetext{
491 “密着 24 時！願望を突き詰めた部屋 - Otaku Room Photographer.”

492 See Appendix A Figure 4.17.

493 See Appendix A Figure 4.18, an image of the traditional mikoshi at Washinomiya Shrine.

${ }^{494}$ See Appendix A Figure 4.19.
} 
popular series, such as the Maplus Portable Navi 2 GPS, which featured the voice of Char Aznable from the Gundam series. ${ }^{495}$ At the 2009 Shizuoka Hobby Show, a Japanese automotive tuning shop began to sell scented motor oil inspired by Lucky $\lesssim$ Star. ${ }^{496}$

Religion in Japan is so deeply ingrained into the culture that there are many actions many Japanese would not initially think to be religious in nature. When considering these anime and manga characters, there is no one canonical or specific series that all otaku adhere to or consider required viewing. For instance, one otaku may be completely devoted to a character in Love Live! while another is devoted to a character in The Idolmaster, but should a different series appear with a more appealing character, both otaku may then devote themselves to this new character from a different series.

\section{OTAKU AND SHRINES}

There are four Shintō shrines and two Buddhist temples that have begun to use popular culture as a means to appeal to otaku. The shrines are the Washinomiya Shrine in Kuki, Kanda Shrine in Tokyo, Chichibu Shrine in Chichibu, and the Ōmi Shrine in Ōtsu, which was mentioned earlier when discussing pilgrimage. The two temples are the Ryōhō-ji Temple in Tokyo and the Jōrin-ji Temple in Chichibu. These are just the shrines and temples that were discovered in the course of research for this dissertation, and this points to an emerging phenomenon. When visiting shrines such as the Washinomiya and Kanda Shrines, the otaku purchase ema, wooden tablets, on which one may write their particular wishes so that shrine visitors may pray for them. ${ }^{497}$ While ema, traditional wooden prayer tablets, with hand-drawn pop culture characters can be found at nearly

\footnotetext{
${ }^{495}$ News Information, Maplus Official Website, n.d., Web, 26 Jul 2016. <http://maplus-navi.jp/>

${ }^{496}$ Daisuke Sueoka, “痛車乗りに朗報！痛いエンジンオイルが登場！”’ASCII, 25 May 2009, Web, 28 Jul 2016. <http://ascii.jp/elem/000/000/421/421525/>

${ }^{497}$ See Appendix A Figure 4.9, which displays ema at the Washinomiya Shrine.
} 
every shrine in Japan, these two particular shrine have racks teeming with ita-ema, fan illustrated wooden prayer tablets, that depict anime and manga characters associated with the respective shrines, as will be discussed later in this chapter. ${ }^{498}$

Shintō shrines and the connection to otaku is a recent phenomenon. In 2007 when the anime Lucky is Star aired, fans discovered that the shrine featured in the opening title sequence of the anime was based on an actual location, the Washinomiya Shrine in Saitama Prefecture. With the advent of the Internet and social media, otaku were able to quickly share this information and suddenly otaku from around Japan were visiting the shrine. Prior to this event, there were instances of anime pilgrimages, but not on the same level as today. ${ }^{499}$ In 1992, there were fans who visited a shrine in Tokyo that was featured in Sailor Moon. However, Takeshi Okamoto noted that the activity of anime pilgrimages was "low-key" in the early 1990s and only became popular "with the widespread use of the internet in the mid-2000s." resulted in an increasing linkage in pop media to Shintō, despite shrines and Shintō elements being present prior to 2007 .

As discussed, otaku practices have become increasingly connected with their patronage of and visits to shrines associated with popular anime. In addition to Lucky is Star, the anime Love Live! was also influential in terms of popularity and formula, as well as affecting the areas surrounding the Shintō shrines that they featured in

\footnotetext{
${ }^{498}$ Ita-ema are hand drawn and decorated wooden prayer tablets made, in this case, by fans of anime and manga. Often the ema feature well-known figures and have wishes that range from what could be considered "normal" to the bizarre, such as asking that an illustrated figure become one's wife.

${ }^{499}$ Kazuaki Nagata, “Japan's Anime Pilgrimages Give Untrod Real-World Locales Economic Boost,” The Japan Times, 4 Sep 2017, Web, 18 Nov 2017. $<$ https:/www.japantimes.co.jp/news/2017/09/04/reference/japans-anime-pilgrimages-give-untrod-realworld-locales-economic-boost/\#.WhH8VxNSyRs>

${ }^{500}$ Kazuaki Nagata, “Japan’s Anime Pilgrimages Give Untrod Real-World Locales Economic Boost."
} 
their series. Many otaku travel to the Washinomiya Shrine to take photographs of the torii that stands outside of the gate, featured in the opening credits and theme song of the Lucky ఓStar anime. The Kanda Shrine sells products that bear the likeness of the characters from Love Live! and many otaku purchase items and take photos of the stairs to a side entrance of the shrine that was featured in the anime.

Two multimedia series that highlight the otaku's devotional practices where "pilgrimages" are concerned are Lucky is Star and Love Live! The otaku that visit the Washinomiya and Kanda shrines take photos, purchase ema, purchase charms, or reenact scenes from the series using cosplay or their figurines. One Twitter user posted an image of his poseable figure of Kagami Hiiragi from Lucky $₹$ Star on the shrine grounds. ${ }^{501}$ For non-otaku, these actions while visiting these shrines can be viewed as profane acts in a sacred space. For the otaku, it could be the opposite, and these figures they take onto the shrine grounds are a merging of profane and sacred. Eliade argues that in many religions, there are manifestations of the sacred entering into the profane world in which humans live and that the two modes of being, sacred and the profane, were dependent on man's position within the cosmos. ${ }^{502}$ Eliade believed "primitive man" was religious while "modern man" was not religious, due to nature becoming desacralized and losing its meaning in a modern and profane world. The otaku are "modern man" in the sense they live in a modern world and are not religious, as the Japanese do not consider themselves to be religious. The otaku manage to be religious-like in their actions and behaviors when they visit sacred spaces, such as the Shintō shrines, and perform specific actions that

\footnotetext{
501 コリン@C91.2 日目東ナ 11b (Corin8187 鷲宮神社なう), “らきうすたが 2003 年 12 月 10 日に連載 を開始してから今日で 13 年目に突入です $(・ \forall ・)$ \#らきすた 就宮,” 9 Dec 2016, 21:05, Tweet. ${ }^{502}$ Mircea Eliade, The Sacred and the Profane, 11, 14-15.
} 
allow them to share space with their pop culture figure. The otaku try to possess that space through their actions, meaning that the lines between sacred and profane are blurred. To a non-otaku, the poseable action figure would be considered a profane item, but to the otaku, they are bringing an embodiment of their pop culture figure into a sacred space.

As discussed in earlier chapters, the Japanese do not consider themselves to be religious, claiming they are $m \bar{u} s h \bar{u} k y \bar{o}$, or non-religious. ${ }^{503}$ Despite claiming to be nonreligious, the Japanese often still perform religious actions, either consciously or unconsciously, that are still connected to what would be considered sacred sites, the Shintō shrines. Shrines are still sacred spaces where visitors still perform the traditional and very solemn behaviors when praying at the shrines and temples; children are still blessed and registered, and weddings are still held there. ${ }^{504}$ While in Japan during June 2016, I observed two traditional weddings, two baby-dedicating ceremonies, as well as visitors praying and purchasing items from the shrines. Some shrines and temples, such as the Kinkaku-ji Temple, have sold official Hello Kitty omamori or in the case of the Kanda Shrine, officially licensed merchandise from a popular anime series about schoolgirls who are pop idols. ${ }^{505}$ This is not in opposition to one another, rather it points to a shift within tradition as pop culture has influenced religion in Japan. There are capsule machines, known as gachapon, that feature small figurines that are Shintō themed and include a small replica of a Love Live! ema located on within the grounds of

\footnotetext{
${ }^{503}$ Many of my Japanese colleagues have confirmed this and many Japanese religious scholars have also pointed it out. See Yukio Matsudo, "Back to Invented Tradition: A Nativist Response to a National Crisis," Religion and Social Crisis in Japan: Understanding Japanese Society through the Aum Affair, Eds. Robert Kisala and Mark Mullins, New York: Palgrave, 2001, 171.

${ }^{504}$ See Appendix B for discussion of witnessing weddings, child blessings, and other practices seen at both Shintō shrines and Buddhist temples.

${ }^{505}$ See Appendix A Figure 4.20 for image of Hello Kitty omamori and Figure 4.21 for a poster depicting official Love Live! merchandise at the shrine.
} 
the Kanda Shrine. ${ }^{506}$

Japan has managed to strike a balance between the sacred and the profane, allowing for an interesting shift of religion and popular culture. Shintō has shifted from a primarily spiritual focused institution to an institution that blends the spiritual with the economic. Although Shintō shrines and Buddhist temples have always had an economic dimension, some shrines and temples, like those discussed in this dissertation, are actively using popular culture to gain more parishioners. In this sense, it would seem that the closest otaku can come to a divine source, a kami-like figure, is by worshipping fictional two-dimensional figures - the pop culture figure. This can be illustrated through a close examination of previously mentioned sites closely linked to pop cultureLucky 2 Star's connection to the Washinomiya Shrine and Love Live!'s connection to the Kanda Shrine.

\section{LUCKY ¿}

An analysis of the 2007 anime series Lucky $\lesssim$ Star will provide a basis for understanding the otaku's connection to, as well their influence on Shintō shrines and practices. The protagonists of Lucky 2 Star are high school girls, two of whom work as miko, shrine maiden or supplementary priestesses, at their family shrine. The series follows their everyday adventures inside and outside of school. The two miko, the Hiiragi sisters Tsukasa and Kagami, work part-time at the fictional Takanomiya Shrine. This shrine is based on the Washinomiya Shrine in Kuki, Saitama in Japan. After the series gained popularity, many otaku began to visit the shrine, especially cosplayers attempting

${ }^{506}$ See Appendix A Figure 4.22. 
to reenact scenes from the anime. ${ }^{507}$ Today, cosplayers are often found during the shrine's annual festival. Traditionally, matsuri, or shrine festival, attendees would wear an appropriate seasonal kimono and possibly a mask. The masks found at these festivals also include those found in a traditional performance or dance that is associated with the shrine, in addition to those offered for the public. Today the masks offered are plastic and are often of pop culture characters and traditional characters. While cosplayers are not entirely out of place at Washinomiya Shrine's matsuri, traditionally speaking, only masks were worn by attendees and full costumes worn by those performing a traditional dance or act. Thus, there are parallels for the cosplayers to take part in the contemporary festivities offered by this shrine's festival.

The anime's protagonists were very popular when the series premiered on April 8, 2007. One of the main characters, Konata, was a self-professed "otaku." She often played video games, read manga, and one episode featured her tricking her friends into attending Comiket, or the Comic Market, which is a large event in Japan often associated with otaku. Fans from around Japan go there to purchase manga, fanmade manga known as doujinshi, as well as to cosplay or take photographs of cosplayers. In the town of Kuki, the Hiiragi sisters are featured on a banner just outside of the shrine and engraved on a black stone, which resembles an ema, located just outside of the torii. ${ }^{508}$ Many of the ema found within the shrine prominently feature Konata, a figure who is an otaku herself and to whom the otaku can relate to.

\footnotetext{
507 “Saitama town turns into 'cosplay’ mecca," The Japan Times, 21 Oct 2010, Web, 23 Nov, 2016. $<$ http://www.japantimes.co.jp/news/2010/10/21/national/saitama-town-turns-into-cosplay-mecca/>; See also “Lucky 2 Star Cast, Fans to Visit Real-Life Shrine," Anime News Network, News, 21 Nov 2007, Web, 23 Apr 2016. <http:/www.animenewsnetwork.com/news/2007-12-05/3-500-lucky-star-fans-flock-to-reallife-shrine-for-event>

${ }^{508}$ See Appendix A Figure 4.23.
} 
While the shrine does not sell officially licensed Lucky $\succsim$ Star ema, it does include a mikoshi, or portable shrine, decorated with the characters from the series in the Haji-sai Matsuri, an autumn festival celebrated in September. Matsuri are traditional festivals that are celebrated in a variety of ways throughout Japan, and are typically associated with local Shintō shrines. During the festival various types of devotion are offered: rituals, prayers, thanks, and entertainment. ${ }^{509} \mathrm{~A}$ parade takes place in which members of the community carry a mikoshi, allowing the kami to experience and partake in the matsuri. As mentioned earlier, fandom behaviors are beginning to affect Shintō practices, and the

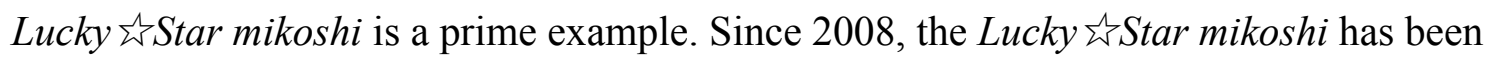
featured at the festival and fans chant the name of Konata or the names of the voice actresses featured in the anime. ${ }^{510}$ This festival clearly shows a blending of traditional religion and pop culture. These mikoshi were originally for the kami to enjoy the festival, but it appears that the characters of Lucky 2 Star are being elevated to some kami-like status. While these characters are not being worshipped, nor are they or the mikoshi replacing the shrine's canonical mikoshi, they are being allowed take part in the matsuri as the kami are thought to. Most matsuri feature food stalls and games, and the Haji-sai, in particular, features pop culture items and events associated with Lucky $\lesssim$ Star. The festival draws in over 100,000 visitors annually, including over 400,000 as recently as $2010 .^{511}$

\footnotetext{
${ }^{509}$ See Brian Bocking. A Popular Dictionary of Shintō. Surrey: Curzon, 1996. 117-118.

510 “らきうすた神舆 WEB サイト [LuckyそStar Mikoshi Official Website of Haji-sai in Washinomiya],” Lucky $\lesssim$ Star Mikoshi Preparation Committee, n.d. Web, 28 Sep 2016. <http://luckystar.wasimiya.com/ja/> ${ }^{511}$ As of 2010, over 400,000 visitors came to the Haji-sai. See Hiroyuki Watanabe, "The Nerdiest Shrine in Japan,” translated by Lena Oishi, Vice, 26 Jan 2010, Web, 25 Sep 2016.

$<$ https://www.vice.com/en_us/article/vdzb94/the-nerdiest-shrine-in-japan>
} 


\section{LOVE LIVE!}

The 2013 series Love Live! is about high school girls who work together to save their school from closing down due to low enrollment by forming a pop music idol group. The girls practice at the nearby Kanda Shrine where the character Nozomi Tōjō works as a miko. This character eventually joins the pop idol group; she is characterized by her attempts to remain mysterious and spiritual. This anime uses the real-life Kanda Shrine as its inspiration and many visitors in the neighborhood of Akihabara in Tokyo visit. At the Kanda Shrine, omamori (talismans or charms), ema (wooden prayer tablets), and other trinkets bearing Nozomi and the other characters of Love Live! are available for purchase from the actual miko who sell them. ${ }^{512}$

The ema decorated and inscribed by visitors at the Kanda shrine include messages of thanks directed to the characters in the series, as well as birthday wishes and declarations of love for the characters. ${ }^{513}$ These messages are for fictional characters that cannot respond to the otaku who write them. These characters transcend a physical reality; they are treated like a kami-like figure that has power so long as they are remembered and do not upset or anger their fans. On the subject of charisma, Max Weber theorizes that a charismatic figure loses power if the figure loses their ability to maintain recognition by proving themselves. ${ }^{514}$ Weber was speaking of humans and not fictional characters. The pop culture figures are fictional characters eliciting devotion from the devotee. The devotee is compelled to worship and to follow, just as the otaku is compelled to venerate the pop culture figure until she has disappointed the otaku.

Similarly, the charismatic leader has to constantly prove their worthiness to their

\footnotetext{
512 See Appendix A Figure 4.24.

${ }^{513}$ See Appendix A Figure 4.25 and Figure 4.26.

${ }^{514}$ Max Weber, Max Weber on Charisma and Institution Building, 20.
} 
followers but can lose their charismatic power if they should fail to impress their followers. Weber says of the charismatic figure, "if they recognize him, he is their master—so long as he knows how to maintain recognition through "proving' himself." These created figures, therefore, exert a charisma that attracts otaku to them, and they maintain that power over the otaku until they no longer "prove" themselves to be what the otaku expects them to be. These pop culture figures exercise the same power over the otaku that a kami would exert over a shrine parishioner. The otaku recognize that the pop culture figure is fictional while Weber's devotees are compelled by a human source.

The locus of charisma seems to consistently shift between the figure, voice actress, and the creator/artist. It transfers from one to another according to the otaku's consumption. Despite not being a real person, these figures possess a charisma brought to life by the writers and voice actresses, which is maintained through the character's presence in media products, such as mobile games and comics. According to Weber, followers are separated from this world, and they are usually single (i.e. celibate) as well as lacking "gainful employment," such as an artist. ${ }^{516}$ These type of people are the most "qualified" to follow one who is charismatic. The otaku are typically celibate and may work only part-time to support their hobbies and cover living expenses. Most Japanese I spoke with about the otaku referred to them as immature or not wanting to grow up, which is also commonly touched upon among otaku scholars.

Despite some otaku having the same favorite pop culture figure, should she lose charisma, the fans become divided with how to respond to the pop culture figure's loss of charisma. In one instance, actress Nitta Emi, who voices Honoka in Love Live!, was

\footnotetext{
${ }^{515}$ Max Weber, Max Weber on Charisma and Institution Building, 20.

${ }^{516}$ Weber, Max Weber on Charisma and Institution Building, 22.
} 
rumored to be an adult video star and a large controversy arose over the unconfirmed rumor. Although Nitta Emi is not actually the character Honoka and has her own personal life outside of her job as a voice actress, many male fans sent death threats to Nitta and destroyed their Honoka merchandise because of the controversy. One fan posted pictures of his destroyed Blu-ray DVDs to his Twitter account, and included links to the official Twitter accounts of Nitta Emi and the Love Live! Staff in his Tweet. ${ }^{517}$ It was later proven that Nitta was not the woman in the video, but the damage had been done. However, many fans did rally together to support the voice actress, and the event has been all but forgotten. But for many fans, the charisma of Honoka was lost and she was no longer their pop culture figure. The time and devotion to these fictional characters is taken very seriously by the otaku.

This incident shows that although the pop culture figure is the center of devotion, at any time they can lose that devotion just as the charismatic leader can lose their power. This devotion and loss of charisma can also be seen in the devotion that pop idol otaku have for their favorite pop idols, as evidenced to what happened to Minegishi Minami, a member of the pop idol group AKB48. These young women can be "punished" for having relationships with real men, because similar to the anime figures, manga characters, and the women that voice animated characters, they are considered "damaged goods" or they disrupt the illusion that they are available for male fans. In 2013, Minegishi had her head shaved and appeared in a YouTube video apologizing for spending a night with a man, which was in violation of her contract. ${ }^{518}$ As a part of their

\footnotetext{
517 転載は許さねえぞ(Pakomarunakaiki), “なんか言ってよ終わりだろ?,” 5 Apr 2016, 22:48, Tweet.

${ }^{518}$ See Dominique Mosbergen, "Minami Minegishi, Japanese Pop Star, Shaves Head as Penance for Dating," Huffington Post, 2 Feb 2013, Web, 17 Jul 2016.

$<$ http://www.huffingtonpost.com/2013/02/02/pop-star-shaves-head-minami-minegishi-
} 
contract, many pop idols are not allowed to date unless it is arranged by their company or in an effort to promote the idol.

\section{SHRINES AND POP CULTURE}

This dissertation noted four Shintō shrines and two Buddhist temples in Japan today that highlight the influence of otaku culture. For instance, Ryōhō-ji Temple located in Hachiouji Hiyoshi-cho in Tokyo, Japan has turned the bodhisattva of entertainment, Benzaiten, into an animated mascot with moe features. ${ }^{519}$ The relationship of anime and manga to these religious sites also reflect current shifts in the role of the Shinto shrine in the secular Japanese community. These current shifts can be traced back to the U.S. Occupation of Japan (1945-1952). During the U.S. Occupation, the creation of the Japanese Constitution and the Shintō Directive coined the term "State Shintō" to differentiate between the state ideology prominent during Meiji and WWII Japan from more "traditional" Shintō belief and practice. ${ }^{520}$ Thus, shrines were no longer afforded the societal power they possessed during WWII Japan and while under the influence of Kokka Shintō, or State Shintō. This resulted in the shift that was the intermingling of Shintō shrines with the secular as just seen with the Kanda Shrine.

The Washinomiya Shrine can be taken as a prime example of this phenomenon.

This shrine is claimed to be one of the oldest shrines in the Kanto region known for the

\footnotetext{
japan_n_2608048.html>

${ }_{519}$ In 2012 the temple also released a social game, has hosted a maid café, and has an animated pop song, which serves as the temple's theme song. See Yunmao Ayakawa, "Otaku Worship in Session at Ryohoji Temple," Otaku USA Magazine, 29 Jan 2013, Web, 23 May 2016.

$<$ http://www.otakuusamagazine.com/SearchAudience/News1/Otaku_Worship_in_Session_at_Ryohoji_Te mple_4949.aspx >; See also Scott R. Dixon, "'Moe Temple' in Tokyo to Woo Anime Geeks with Maid Café," Rocket News 24, 27 Oct 2013, Web, 23 Apr 2016. <http://en.rocketnews24.com/2013/10/27/moetemple-in-tokyo-to-woo-anime-geeks-with-maid-cafe/>; Ryōhō-ji's website at <http://ryohoji.jp>

${ }^{520}$ H. Byron Earhart, Religion in the Japanese Experience: Sources and Interpretations, Encino: Dickenson Publishing Company, 1974, 38.
} 
Washinomiya Saibara Kagura, a traditional Shintō dance. ${ }^{521}$ This shrine and the economy of the town surrounding it were revitalized thanks to the 2007 anime Lucky 2 Star. The town's economy was struggling during the period of recovery from the Bubble burst of the 1990s and the continuing recession of the early 2000s. The chamber of commerce recognized that attracting the otaku and other tourists to see the shrine would help provide economic relief. ${ }^{522}$ The shrine was featured in several anime and gaming magazines, such as Newtype, detailing the relationship of the shrine and locations around the shrine to the anime as well as featuring a map and directions to the shrine from the popular otaku spot Akihabara. ${ }^{523}$ Many shops located in Kuki and near the shrine sell anime-related products, ranging from charms to costume shops allowing otaku to take pictures of themselves dressed as their favorite characters. ${ }^{524}$

In 2007, a special event was held in Ootorichaya Washinomiya, a restaurant next to the shrine, which featured special food, and official merchandise associated with the series. ${ }^{525}$ One such piece of merchandise were mobile phone straps which were stylized as miniature versions of the ema, found at most Shintō shrines, and featuring images of the characters on them; a tour of the shrine by the "Hiiragi sisters" was also featured, by the voice actresses Emiri Kato and Kaori Fukuhara, in which the attendees and "sisters" would "pray for a "bright future for Lucky 2 Star.," 526

\footnotetext{
521 "Saitama Prefecture: Fans Flock to Real-Life Home of Anime Hero," Around Japan, Asahi, 18 Sep 2007, Web, 13 Apr 2016. <http://www.asahi.com/english/Herald-asahi/TKY200709180058.html>

${ }^{522}$ Hiroko Tabuchi, "Popular Cartoon Series Makes Japanese Shrine a Magnet for Fans: Devotees are Mainly Young Men, Who Dress Like the Characters - In Miniskirts," The Wall Street Journal, 30 Jul 2008 , Web, 13 Apr 2016. <https://www.wsj.com/articles/SB121737740486095275>

${ }^{523}$ The August issue of Newtype featured a map and directions to the shrine. See Newtype Moving Pictures Magazine, Volume 6, Number 8, August 2007.

${ }^{524}$ Hiroko Tabuchi, "Popular Cartoon Series Makes Japanese Shrine a Magnet for Fans: Devotees are Mainly Young Men, Who Dress Like the Characters - In Miniskirts."

525 "Lucky $\lesssim$ Star Cast, Fans to Visit Real-Life Shrine."

526 "Lucky $\succsim$ Star Cast, Fans to Visit Real-Life Shrine."
} 
The other prominent Shintō shrine associated with an anime series illustrating this socio-religious phenomenon is the Kanda Shrine. The Kanda Shrine was founded in 730 CE but its current location was established in 1616. It is located in Tokyo near the bustling electronics district, Akihabara. The location of this shrine has made it popular with visitors to Akihabara, which is known for its electronics and as a mecca for the otaku. While this shrine is popular with technophiles and otaku alike, it has a long history as the tutelary shrine for all of Tokyo. Prior to the shrine being featured in the anime Love Live!, the shrine sold charms for electronics, IT systems, data, as well as charms for success in business. ${ }^{527}$

In 2015, administrators of the shrine announced via social media Twitter that the character of Nozomi Tōjō would become the shrine's official mascot. ${ }^{528}$ This figure is popular with many of the fans of Love Live!. Nozomi has now been attached to a historical shrine, an actual physical space that the otaku may visit outside of the virtual reality (i.e. animation) that she was created in - giving her an aura of being physically "real." Her presence brings visitors to the shrine who will also inevitably purchase something in the nearby shops in Akihabara, thus boosting the local economy. Although Kanda Shrine already existed as a popular shrine for business workers in the Tokyo area, its link to Love Live! made it more successful by attracting more fans.

By contrast, the Washinomiya Shrine does not sell official Lucky $\lesssim$ Star merchandise; nevertheless, it, too, is a draw for tourism in the area, helping to boost the economy of the town. The ema bought at Washinomiya are then often decorated, by the

\footnotetext{
${ }^{527}$ Kanda Shrine Official Website, “お守り (Amulets),” Kanda Myojin, n.d., Web, 18 Nov 2017. $<$ http://www.kandamyoujin.or.jp/omamori/detail/?id=7>

528 神田明神(Kanda_Myoujin), “Kandamyoujin shrine announces adoption of anime character as official mascot," 2 Jan 2015, 10:33 a.m., Tweet.
} 
otaku, with characters from Lucky $\lesssim$ Star, most often the otaku-like character Konata Izumi, and the nearby cafes and shops feature themed items for sale. ${ }^{529}$ But Washinomiya does exhibit the same level of fervor felt at Kanda Shrine and nearby Akihabara. When I visited the Washinomiya Shrine, the town surrounding it was small. It was quiet compared to the sounds of city life in Akihabara. At the Kanda Shrine many people crowded the streets, and buildings surrounded me. This was in stark contrast to the quiet of Kuki, where the buildings were no taller than three or four stories. The area around the Kanda Shrine also had convenience stores and advertisements everywhere, whereas the Washinomiya Shrine was quiet and surrounded by trees, where the only advertisements found in the train station. It should be taken into consideration that Akihabara has long been a center of otaku activity. The Washinomiya Shrine and the city of Kuki gained

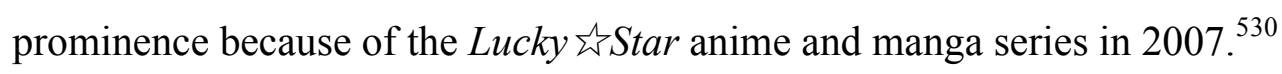

In 2011, the anime Ano Hi Mita Hana no Namae o Bokutachi wa Mada Shiranai (Anohana: The Flower We Saw That Day) (2011), or Ano hana, aired on television and was set in Chichibu, Saitama. Unlike Lucky ఓ̧了 Star and Love Live!, Anohana's characters have not become featured at the shrines, such as being featured on a mikoshi or being deemed official mascots. The series centered on six childhood friends who grow apart but are brought back together through a series of events. Anohana falls under the genre of drama, as it is more serious in nature when compared to Lucky ¿ł Star and Love Live! which are comedies. Featured in the anime are the Chichibu Shrine and the Jörin-ji

\footnotetext{
${ }^{529}$ See Appendix A Figure 4.27. Also see Appendix B for discussion of the series' influence on the area. ${ }^{530}$ For more information on the history of Akihabara, see Satoru Kikuchi "The Transformation and Diffusion of 'Otaku' Stereotypes and the Establishment of 'Akihabara' as a Place-brand," Debating Otaku in Contemporary Japan: Historical Perspectives and New Horizons, Eds. Patrick W. Galbraith, Thiam Huat Kam, and Björn-Ole Kamm, London: Bloomsbury Academic, 2015, 147-161.
} 
Temple, although the Chichibu Shrine only makes a brief appearance. ${ }^{531}$ This series is credited with helping maintain the Jōrin-ji Temple, which had begun to struggle financially in addition to losing followers. ${ }^{532}$

Fans coming to see the Jōrin-ji Temple have affected the town and temple's economy, but the relationship between the anime and religious sites do not appear to be on the same level as those seen with the Washinomiya Shrine and the Kanda Shrine. Scholar Mark MacWilliams has argued, in the case of Anohana, "commercialism and pilgrimage are one and the same," but the Jōrin-ji Temple appears to lack the same kamilike reverence of anime characters as seen in the case of the Washinomiya Shrine and Kanda Shrine. ${ }^{533}$ Similar to the two shrines, the Jōrin-ji Temple does sell ema featuring the characters and people leave ita-ema of the characters where the ema are hung at both sites. ${ }^{534}$ The Chichibu tourist office offers bike rentals along with free Anohana maps that feature the locations from the anime. ${ }^{535}$ Anohana's fans are not like the otaku who visit the Washinomiya Shrine or the Kanda Shrine, due to the differences in genre and anime aesthetics between these series. Anohana does not focus on girls that meet with the moe aesthetic and the series was part of the drama genre. The Jōrin-ji Temple is normalizing anime pilgrimages to the shrine to self-consciously expand beyond the scope of older and traditional parishioners. To gain pilgrims, the temple is using the popularity of the anime

\footnotetext{
${ }^{531}$ The Jōrin-ji Temple is part of a traditional religious pilgrimage known as the Chichibu pilgrimage, which features 34 temples in the area devoted to Kannon, the Bodhisattva of Mercy. See "Chichibu: A Springtime Pilgrimage," NHK World, Journeys in Japan, 3 May 2016, Web, 15 Jul 2017. $<$ https://www3.nhk.or.jp/nhkworld/en/tv/journeys/journey_20160503.html>

${ }^{532}$ Shinya Matsumoto, "Loyal Fans of 2011 Anime Show “Anohana' Help Saitama Temple," Asahi, 2 Mar 2017, Web, $15 \mathrm{Jul}$ 2017. <http:/www.asahi.com/ajw/articles/AJ201703020010.html>

${ }^{533}$ Mark MacWilliams, "Abstract," Dynamics of Religion: Past and Present: Proceedings of the XXI World Congress of the International Association for the History of Religions, Eds. Christoph Bochinger and Jörg Rüpke, Berlin: Walter de Gruyter GmbH \& Co KG, 2016, 392.

${ }^{534}$ Ken Iikura-Gross, "Touring the Real-Life Anohana," Anime News Network, News, 25 Mar 2016, Web, $15 \mathrm{Jul}$ 2017. <http://www.animenewsnetwork.com/feature/2016-03-25/touring-the-real-lifeanohana/.100253>

${ }^{535}$ Ken Iikura-Gross, "Touring the Real-Life Anohana."
} 
to its advantage. Thus, these signs point to this phenomenon moving beyond the otaku.

\section{POP CULTURE KAMI}

As discussed in Chapter Two, the concept of what constitutes a kami depends on a variety of certain conditions, but the concept itself is ultimately vague. Some common classifications of the kami are attributed to certain phenomena, natural landscapes, nature itself, and humans who are considered to have been exceptional in their lifetime. ${ }^{536}$ Natural elements such as storms and the sun were also personified as kami, Susanō and Amaterasu respectively. Warriors, scholars, and others were deified as kami after their deaths, because they were believed to have possessed a great spirit. Tools and weapons have been deified, including a sword that Ieyasu Tokugawa himself asked to be deified, proclaiming "this sword must be venerated as a god who [will make] our descendants [endure] for ever and ever." ${ }^{, 537}$ The sword is supposedly still kept in Kunō-zan Tōshō-gū shrine. $^{538}$

More contemporary figures receive certain accolades that border on veneration. On such figure is Osamu Tezuka, the famed comic artist and animator, who is often referred to as "manga no kamisama," or "god of comics." Many artists and animators look to Tezuka as an inspiration, although he is not officially recognized or affiliated with a shrine. Many acting troupes pay respects to their founders of their schools, looking to them as a kami who will continue to guide the actors to success and so on. As these things and people may be officially and unofficially like kami, they are not permanent and stable figures like the canonical kami, such as Amaterasu. Anime and manga figures

\footnotetext{
${ }^{536}$ See Sokyo Ono, Shintō: The Kami Way, Rutland: Tuttle, 1962.

537 Shintō in History: Ways of the Kami, Eds. John Breen and Mark Teeuwen, Honolulu: University of Hawai'i Press, 2000, 148.

${ }^{538}$ Shinto in History: Ways of the Kami, 148.
} 
that are the objects of the otaku's devotion possess a number of similarities with kami and these deified figures. There is a certain reverence given to these figures, though otaku devotees do not pray to them for blessings, nor are the otaku subordinate to them as is the typical relationship between a human and a deity. Instead, the otaku pay reverence to these characters but have the potential to reject the character at any time, which is not often something one does when cultivating an individual relationship with a deity. These figures represent a blurring of ingrained religious and cultural ideas with the secular and modern world. These relationships highlight the ambiguity of celebrity and divinity, profane and sacred.

There are some otaku who claim that certain anime characters are kami, using the kanji for kami (神) to refer to a character. ${ }^{539}$ For instance, one Twitter user claimed that the "movie version of Nico [their favorite character from LoveLive!] was a god after all (Gekijo-ban no Niko ni-wa yappari kamida yo ne)" which was accompanied by an emoji, which are ideograms and smiley faces used electronic communication and web pages, of an angel with a halo. ${ }^{540}$ Another Twitter user referred to their favorite character, Konata Izumi, "Izumi Konata is equal to God (Izumikonata wa kami ni hitoshī)." ${ }^{541}$ The interesting thing to note is that the otaku are not using the kanji “ネ申” to refer to their favorite characters. Typically, this kanji is used in Internet slang, which is read as "kami" but means "incredible," or "fantastic," rather than the traditional translations of "kami." In the previous mentioned examples, the otaku used “神” rather than “齐申” to describe

\footnotetext{
${ }^{539}$ It should be noted that while the Japanese consider themselves to be non-religious, they do not typically use the term "kami" very lightly - the names of the kami, or other deities, are not typically taken in vain. When the term "kami" is used it is with a certain level of reverence.

540ナツキン!@にこルビィ!来年受験生! (Natsukin_Anime_), “劇場版のにこにーはやっぱり神だよね $\because$," 19 Jan 2017, 4:14 a.m., Tweet.

541木本 牙狼 (byogarou),“泉こなたは神に等しい,”29 Jun 2014, 10:56 a.m., Tweet.
} 
or refer to their beloved character. One only need to use the kanji “神” and a character's name on Twitter to find numerous examples of otaku proclaiming their beloved figure to be a kami.

There are other terms otaku could use to refer to these figures as a "goddess," much like Western fandoms referring to rockstars or actresses as "gods," but they use the kanji “神” for kami instead of Internet slang or Western-sounding words. Thus, I feel that the term "pop culture kami" appears to be fitting, as "kami" used by otaku to refer to their favorite character. There is a certain level of reverence for these characters by using this specific kanji. Using the term "pop culture" signifies that this figure is from a secular world, namely popular culture. The use of "kami" is to signify the importance of this figure and the emotions she inspires in the otaku, as well as highlighting her potentially "sacred" nature for the otaku devotees. While the pop culture kami occupies a place of importance in the life of the otaku and shares some similarities with the kami, it should be noted that she does not replace the canonical kami of Shintō. She is a reflection of otaku incorporating Shintō elements into their consumption of popular culture.

The pop culture kami provides the otaku with a sense of happiness and possibly feelings of love, but again, they are not prayed to for blessings as seen with traditional kami. But then again, as has been discussed, the idea of kami is vague and there are humans who have been deified unofficially by certain groups, like Tezuka. Like kami, these figures possess a certain charisma. As discussed in Chapter Two, certain humans are deified as kami after death. Sokyo Ono points out that the kami "cannot be distinguished from the deities or spirits of animism or animatism, but in modern Shintō 
all kami are conceived in a refined sense to be spirits with nobility and authority." ${ }^{, 542}$ These pop culture figures possess a certain level of authority as they are carefully put on display and the otaku talk about them with levels of reverence that one might see a nonotaku use when visiting a Shintō shrine or natural site associated with a certain kami.

These pop culture kami, typically originating as two-dimensional female characters in anime and manga, are often the objects of many male otaku ritualized behaviors. While the otaku do not always share the same desires, practices, or are not always devoted to the same female figure, the term refers to the role of these figures within popular culture and their status as a deity-like or sacred figure. These are the figures that otaku will devote themselves to by purchasing items bearing her likeness, constructing shrine-like places for items dedicated to her, and providing food offerings like those found in traditional Shintō and Buddhist worship. Some otaku, such as the young man I met in Nara, note the happiness or pleasure that these figures bring into their lives. Unlike traditional kami, this figure cannot provide succor or boons for its devotees, but instead brings them happiness or joy. There is potential for these figures to considered kami in the future, as this is still a relatively recent phenomenon.

Kami is not a term limited to just the gods or nature itself. The otaku have created a quasi and kami-like being in the pop culture figures that they become enamored with. In A Popular Dictionary of Shintō, Brian Bocking defines kami as qualifying "a name or object rather than standing alone, indicating that the object or entity has kami-quality" and that "Kami may refer to the divine, sacred, spiritual and numinous quality or energy of places and things, deities of imperial and local mythology, spirits of nature and place,

${ }^{542}$ Sokyo Ono, Shintō: The Kami Way, 7. 
divinised [sic] heroes, ancestors, rulers and statesmen." ${ }^{, 543}$ As seen with the official and unofficial deification of humans and objects, it would state to reason that the pop culture figures that occupy the minds and interests of the otaku possess the ability to become kami-like.

Traditionally speaking, the kami could be anything found in nature and everyday life. In the present, manmade objects are clearly thought to possess some spirit as there are folktales of common household objects, such as an umbrella, becoming possessed by a spirit if not disposed of properly and when it reaches a certain age. ${ }^{544}$ Shintō priests offer blessings for one's electronics or car. Anime and manga characters, as well as the plastic figurines versions of those characters, are manmade products but they constitute a part of nature and everyday life for the otaku. The term "pop culture kami" highlights the figure's religiosity in a contemporary world, as well as potentially "sacred" nature this figure holds for their otaku devotees. My use of the term, in addition to lack of a better word, is to reflect the way in which otaku are using Shintō elements in their consumption of popular culture and the melding of religious traditions and elements. Despite the pop culture kami not being a canonical kami found in Shintō or a permanent and stable figure, it does highlight the ambiguity between the sacred and the profane in Japanese culture and religious tradition.

\section{CONCLUSION}

The otaku are a part of a socio-religious phenomenon and participate in many facets of Japanese economy, culture and tradition. In the last few decades, the otaku have incorporated significant aspects of Japanese religious behavior into their relationship with

\footnotetext{
${ }^{543}$ Brian Bocking, A Popular Dictionary of Shintō, 84.

544 These objects are among the many yōkai, supernatural beings, found in Japanese folklore. The umbrella yōkai is called kasa-obake.
} 
popular culture. The image of the miko became popular because of the depictions of fictional heroines in anime and manga, blending the traditional religious figure with a young woman in a high school uniform. Azuma argues, "the obsession with Japan in otaku culture did not develop from Japanese tradition by rather emerges after this tradition had disappeared." ${ }^{545}$ For Azuma, it is clear what has shaped contemporary Japan and ideas of Japanese culture - the otaku themselves. However, it would appear that the culture never disappeared but rather has been influenced and transformed through the otaku. The otaku's images of Japan reflect a postwar Japan that that was heavily influenced by the logic of consumer society—American-style capitalism. ${ }^{546}$ These images of Japan affect the presentations of Japan at Shintō shrines as well, linking traditional Japanese culture to a modern society via popular culture.

Religions do not remain the same or unchanged. Emile Durkheim said, "religion seems destined to transform itself rather than disappear." ${ }^{547}$ This seems especially true in the case of Japan as religion has influenced, been incorporated into, and influenced by popular culture. These transformations of religious devotional energy into a secular devotional energy can be seen in the changes within popular culture and religious sites. The emerging prominence and influence of otaku subculture highlights an interesting dynamic between religion and popular culture. By studying the otaku and their consumptive behaviors of popular culture, one might trace the continuation of various religious traditions and popular culture as they influence one another in a world connected by increasing technology.

\footnotetext{
${ }^{545}$ Hiroki Azuma, Otaku: Japan's Database Animals, 15.

${ }^{546}$ See Hiroki Azuma, Otaku: Japan's Database Animals, Trans. Jonathan E. Abel and Shion Kono, Minneapolis: University of Minnesota Press, 2009, 3-24.

${ }^{547}$ Emile Durkheim, The Elementary Forms of Religious Life, 432.
} 


\section{OTAKU GENERATIONS}

When looking towards the future, we often need to look first, to the past. By seeing and understanding the past, we can better hypothesize what the future may hold. To best understand what the future may hold for the otaku and this phenomenon, this section will discuss the generations of otaku that have evolved since the 1980s. While Eiji Ōtsuka focuses on locating the otaku within a historical context, Toshio Okada instead reflects on the generational shifts since the otaku were labelled "otaku." Okada claims "what exactly 'otaku' refers to differs by generation." ${ }^{, 548}$ For Okada, the early use of "otaku" was pejorative and the discrimination of otaku much more pronounced in the 1980s when compared to today. ${ }^{549} \mathrm{He}$ argues that the "early days of 'otaku' were a terrible time (tondemo nai jidai). ${ }^{, 550}$ Some may even argue that he is akin to an old person who is criticizing the kids today, especially when he makes claims that the otaku of today are not like the otaku when he was young. ${ }^{551}$ Not to mention the fact that Okada claims he was part of the reason that otaku have been regarded more positively than they once were, and not thanks to the commodification of otaku culture. ${ }^{552}$ Regardless, Okada felt called to open a seminar at the University of Tokyo in 1996 due to a rising interest in otaku habits, but found himself disappointed at the "otaku" who took the course. He states, "These days, fewer people have reached the level of extraordinary intelligence that is required of otaku." ${ }^{553}$ Despite his jaded feelings with generations today, his comments on the generations and shifts between the otaku are valuable to consider in the context of

\footnotetext{
${ }^{548}$ Toshio Okada, "The Transition of Otaku and Otaku," 164.

549 Toshio Okada, "The Transition of Otaku and Otaku," 164.

550 Toshio Okada, "The Transition of Otaku and Otaku," 164.

${ }^{551}$ Toshio Okada, "The Transition of Otaku and Otaku," 163.

552 Toshio Okada, "The Transition of Otaku and Otaku," 168.

${ }^{553}$ Toshio Okada, "The Transition of Otaku and Otaku," 168.
} 
what the future holds for the otaku and their growing culture.

Okada claims that the first generation of otaku were the TV generation "christened by Nakamori Akio in 1983." ${ }^{554}$ He defines the first generation as "those people who were involved in otaku activities around 1980, who called one another 'otaku,' liked anime and manga or were exposed to lots of them and were seen as a little strange by those around them." generation were not otaku because they "did not experience 'alienation from society and conflict' (seken kara no sogai to kattō), which is a defining characteristic of otaku. "$" 556$

The second generation grew up during the 1990s when "otaku" permeated the general public due to the recent arrest of Tsutomu Miyazaki in $1989 .{ }^{557}$ The second generation is characterized by their being “consumed by a 'love of theories of otaku' (otaku ron ga daisuki)" and their hobbies being "their 'raison d'être' (ikigai) and [...] their "cross to bear." ${ }^{558}$ This generation desires to be accepted by the mainstream, hence their engagement in theorizing about the otaku.

The third generation, according to Okada, live in an area of mixed media. With regards to the third and current generation of otaku, Okada argues that they are familiar with a series but cannot recall how they are familiar with it, especially when it comes to the "original story" and the "derivatives works." 559 This third generation of otaku are not only encountering mixed media, "but there is confusion about what works are old and new. ${ }^{, 560}$ Due to this mixing of media and confusion regarding the original works, Okada

\footnotetext{
554 Toshio Okada, "The Transition of Otaku and Otaku,"171.

555 Toshio Okada, "The Transition of Otaku and Otaku,"171.

${ }^{556}$ Toshio Okada, "The Transition of Otaku and Otaku,"171.

557 Toshio Okada, "The Transition of Otaku and Otaku," 172.

558 Toshio Okada, "The Transition of Otaku and Otaku," 173.

559 Toshio Okada, "The Transition of Otaku and Otaku," 172-173.

${ }^{560}$ Toshio Okada, "The Transition of Otaku and Otaku," 173.
} 
claims that the third generation of otaku are cultivated and that they have grown up in an era where "they have had access to merchandise targeting otaku since birth." ${ }^{.561}$ Thus, this current generation could be considered "'natural born otaku people' (kissui no otakubito). ${ }^{, 562}$

The third generation, as Okada describes them, are different from previous generations due to the accessibility of merchandise geared towards them. He also points out that the third and current generation has had access to "high-quality manga, anime and games, products that have almost already reached perfection, and are flooded with products made not for children, but rather specifically for otaku." ${ }^{, 563}$ Okada concludes that they are consumers by birth and only exist to be "squeezed for profits."

Although Okada gives great detail to three generations of otaku, he goes on to claim that there is also a fourth. However, he only says of them that they are people who do not wish to grow up and instead prefer otaku culture because "they can enter and enjoy [it] as children" while remaining hidden from the public. ${ }^{565}$ What Okada does not touch on in his discussion of the otaku generations is the possibility that this third generation, which is he is critical of, will give way to a fifth generation that may reject the ideas and habits of the third and fourth generations. This fifth generation may even attempt to reach back for a return to a purer appreciation of popular culture and once again become the "'strong otaku' (tsuyoi otaku) [who] can 'refuse the norm' ('futsu no hitei’). ${ }^{566}$

\footnotetext{
${ }^{561}$ Toshio Okada, "The Transition of Otaku and Otaku," 173.

${ }^{562}$ Toshio Okada, "The Transition of Otaku and Otaku," 173.

${ }^{563}$ Toshio Okada, "The Transition of Otaku and Otaku," 173.

${ }^{564}$ Toshio Okada, "The Transition of Otaku and Otaku," 173.

${ }^{565}$ Toshio Okada, "The Transition of Otaku and Otaku," 173-174.

${ }^{566}$ Toshio Okada, "The Transition of Otaku and Otaku," 167.
} 


\section{LOOKING FORWARD}

As each otaku generation has transformed due to historical/cultural events and technological advancements, there is a possibility that the otaku may one day intersect their consumption of pop culture kami with Japanese artistic aesthetics. ${ }^{567}$ Japanese culture has a long history of illustrated narratives and visual art, plus a tradition of deifying manmade and natural objects that exude some essence. Two examples of this are Ieyasu Tokugawa's sword ${ }^{568}$ and Mount Fuji itself. ${ }^{569}$ Right now moe influences the creation of anime and manga characters, who are often regarded in a fetishized manner, but in the future, there could be a focus on the aesthetic experience and value of the figures. This is not entirely out of the realm of possibility considering the deification of manmade objects that possess a level of "great spirit," and because it has happened once before. When ukiyo-e was being mass-produced as art for a burgeoning middle class, it is now globally recognized as fine art. Therefore, contemporary anime and manga aesthetics may shift and become regarded as traditional art aesthetics in the future. There is a possibility of a continuing transformation that elevates the fetishized object into an aesthetic object. Once a level of perfection has been reached within anime, manga, and video games, the otaku may incorporate a focus on the artistic aestheticism of the object, maybe even a philosophy, while rejecting the materialism and the consumerism once associated with the fetishized objects. What was once considered old may become new, akin to the hipster trends seen in the West. The pop culture kami may become more permanent and clearly defined.

\footnotetext{
${ }^{567}$ Traditional Japanese artistic aesthetics are often marked by minimalism, such as simple lines or materials, and aesthetic ideas from Zen Buddhism.

${ }_{568}$ See Chapter Two, page 72.

${ }^{569}$ See Chapter Two, pages 71-75.
} 
With media becoming more advanced and technology more accessible, there is a possibility that the high quality anime, manga, and games Okada says have reached near perfection will manage to attain a level of perfection that is in harmony with the otaku. ${ }^{570}$ Already there are products that combine technology with otaku sensibilities, such as Gatebox, which features a holographic girl who is both "girlfriend" and personal assistant for the mere price of $\$ 2500 .{ }^{571}$ With this device and the many other products that are being offered to otaku sensibilities, the next generation of otaku could become more in tune with technology as media becomes "perfected" and the pop culture kami can be given "life" and a programmable nature that allows them to respond to the otaku. Considering the rapid growth of technology to advancements within several years rather than decades, this phenomenon could grow and become more widespread than it already is. Okada made the claim that, "To be an otaku is to reach beyond the ordinary. Nietzsche thought that strong contempt for the masses would create the Übermensch." 572 If the otaku do become a kind of übermensch, or superhuman, then this points to an interesting series of dynamics that would take place when these newest aspects of otaku culture would be translated and made accessible to a global world. ${ }^{573}$

Some of the many goals of this dissertation are to open and further dialogue on the intersections of religion and popular culture in Japan; and what that means for globalization and future generations of otaku. Looking forward, this socio-religious

\footnotetext{
${ }^{570}$ Toshio Okada, "The Transition of Otaku and Otaku," 173.

571 Stacy Liberatore, "The \$2500 Holographic 'Girlfriend' that can Double as a Virtual PA (and Even Sent 'I Miss You’ Messages When You're Away,’ Daily Mail, 19 Dec 2016, Web, 18 Nov 2017. $<$ http://www.dailymail.co.uk/sciencetech/article-4049486/The-2500-holographic-girlfriend-double-virtualPA-send-miss-messages-away.html>

${ }^{572}$ Toshio Okada, "The Transition of Otaku and Otaku," 167.

573 Some otaku, as has been noted, view themselves as connoisseurs of Japanese pop culture and that they have a certain sense of superiority compared to non-otaku. Okada says of the otaku, "As a result, it is inevitable that society does not understand and excludes [the otaku], but [otaku] do not care, because they sincerely believe that society is full of idiots." Toshio Okada, "The Transition of Otaku and Otaku," 167.
} 
phenomenon has the potential to grow outside of the few examples that I have provided. There have already been numerous transitions of how the otaku identify themselves as a subculture, how they influence popular culture, and their consumptive practices combining religious elements. As technology grows, so, too, may the lines between real and virtual, sacred and profane be further blurred. 


\section{REFERENCES}

Aida, Miho. "The Construction of Discourses on Otaku: The History of Subcultures from 1983 to 2005." Debating Otaku in Contemporary Japan: Historical Perspectives and New Horizons. Eds. Patrick W. Galbraith, Thiam Huat Kam, and Björn-Ole Kamm. London: Bloomsbury Academic, 2015.105-128. Print.

“AKB48 公式サイト|メンバー情報 [AKB48 Official Site — Member Information].” Official AKB48 Website. n.d. Web. 13 Jul 2016.

$<$ http://www.akb48.co.jp/about/members/>

Akimoto, Akky. "Digital Manga Giving Print a Run for Its Money.” The Japan Times, 11 Oct 2014. Web. 15 Jul 2017. $<$ http://www.japantimes.co.jp/life/2014/10/11/digital/digital-manga-giving-printrun-money/\#.WWz_ZNPyuRs>

Alt, Matt, and Hiroko Yoda. Hello, Please! Very Helpful Super Kawaii Characters from Japan. San Francisco: Chronicle Books, 2007. Print.

Ama, Toshimaro. Why Are the Japanese Non-Religious?: Japanese Spirituality: Being Non-Religious in a Religious Culture. Lanham: University Press of America, 2005. Print.

“Animators' Harsh Work Conditions.” Biz/Tech, NHK World. 27 Apr 2015. Web. 24 Feb 2016. <http://www3.nhk.or.jp/nhkworld/english/news/20150428_20.html> Ayakawa, Yunmao. “Otaku Worship in Session at Ryohoji Temple.” Otaku USA Magazine, 29 Jan 2013. Web. 23 May 2016. 
$<$ http://www.otakuusamagazine.com/SearchAudience/News1/Otaku_Worship_in _Session_at_Ryohoji_Temple_4949.aspx>

Azalea (Azalea01606534). “海未ちゃん誕生日おめでとう!!!俺はこれからも、君を 愛し続けていくよ [Happy Birthday Umi-chan! I will continue to love you in the future]." 14 Mar 2016. 8:00 a.m, Tweet.

Azuma, Hiroki. Otaku: Japan's Database Animals. Trans. Jonathan E. Abel and Shion Kono. Minneapolis: University of Minnesota Press, 2009. Print.

Baseel, Casey. "What Do Japanese People Think of When They Hear the Word ‘Otaku?’” Rocket News. 23 Apr 2014. Web. 25 Mar 2016. $<$ http://en.rocketnews24.com/2014/04/23/what-do-japanese-people-think-ofwhen-they-hear-the-word-otaku/>

Baseel, Casey. "Man Arrested for Hunting the Nerdiest Game: Akihabara Otaku." Rocket News. 13 May 2014. Web. 25 Mar 2016. $<$ http://en.rocketnews24.com/2014/05/13/man-arrested-for-hunting-the-nerdiestgame-akihabara-otaku/>

Baseel, Casey. "AKB48 Fan Shows His Love the Only Way He Knows How: Buying \$300,00 Worth of CDs." Rocket News 24, 22 May 2014. Web. 5 Jul 2016. $<$ http://en.rocketnews24.com/2014/05/22/akb48-fan-shows-his-love-the-onlyway-he-knows-how-by-buying-300000-worth-of-cds/>

Baseel, Casey. "Wow, Literature is Cute! Hiroshima Library Designs Anime Mascots for Decimal Classifications.” Rocket News 24, 27 Sep 2014. Web. 29 Sep 2017. $<$ https://en.rocketnews24.com/2014/09/27/wow-literature-is-cute-hiroshimalibrary-designs-anime-mascots-for-decimal-classifications/> 
Baseel, Casey. "Japanese Idol Singers Put on Hazmat Suits Before Hugging Fans at Tokyo Event.” Rocket News 24, 8 May 2017. Web. 18 Nov 2017. $<$ https://en.rocketnews24.com/2017/05/08/japanese-idol-singers-put-on-hazmatsuits-before-hugging-fans-at-tokyo-event $\% \mathrm{E} 3 \% 80 \% 90$ videophotos $\% \mathrm{E} 3 \% 80 \% 91 />$

Baseel, Casey. "Japanese Idol Singer Has an Important Request for Fans: Please Use Deodorant.” Rocket News 24, 21 Aug 2017. Web. 18 Nov 2017. $<$ https://en.rocketnews24.com/2017/08/21/japanese-idol-singer-has-an-importantrequest-for-fans-please-use-deodorant/>

Bellah, Robert N. Tokugawa Religion: The Cultural Roots of Modern Japan. New York: The Free Press, 1985. Print.

Berger, Peter L., and Thomas Luckmann. The Social Construction of Reality: A Treatise in the Sociology of Knowledge. Garden City: Doubleday, 1966. Print.

Berger, Peter L. The Sacred Canopy: Elements of a Sociological Theory of Religion. Garden City: Anchor Books, 1967. Print.

Biswas, Sampa. Indian influence on the Art of Japan. New Delhi: Northern Book Centre, 2010. Print.

Bocking, Brian. A Popular Dictionary of Shintō. Surrey: Curzon Press, 1996. Print. Brasor, Philip. “The Obsession Over Those Dumbed Down Cute Mascots." The Japan Times, 3 Aug 2008. Web. 29 Sep 2017. $<$ https://www.japantimes.co.jp/news/2008/08/03/national/media-national/theobsession-over-those-dumbed-down-cute-mascots/> 
Brau, Lorie. "Rakugo Fans at Play: Promoting the Art, Creating Community, Inventing Sales." Fanning the Flames: Fans and Consumer Culture in Culture in Contemporary Japan. Ed. William W. Kelly. Albany: State University of New York Press, 2004. 127-149. Print.

Breen, Jim. Jim Breen's WWWJDIC, n.d. Web. 18 Nov 2017.

$<$ http://nihongo.monash.edu/cgi-bin/wwwjdic?1C>

Breen, John, and Mark Teeuwen. Shintō in History: Ways of the Kami. Honolulu: University of Hawai'i Press, 2000. Print.

Brooker, Will. "Everywhere and Nowhere: Vancouver, Fan Pilgrimage and the Urban Imaginary." International Journal of Cultural Studies 10.4 (2007): 423-444. Print.

Buddhas and Kami in Japan: Honji Suijaku as Combinatory Paradigm. Eds. Mark Teeuwen and Fabio Rambelli. London: Routledge, 2002. Print.

木本 牙狼 (byogarou). “泉こなたは神に等しい [Izumi Konata wa kami ni hitoshī].” 29 Jun 2014. 10:56 a.m., Tweet.

The Cambridge History of Japan: Early Modern Japan, Ed. John Whitney Hall, Cambridge: Cambridge University Press, 1988. Print.

Cavaye, Ronald. Kabuki: A Pocket Guide. North Clarendon: Tuttle Publishing, 1993. Print.

“Chichibu: A Springtime Pilgrimage.” NHK World, Journeys in Japan, 3 May 2016. Web. 15 July 2017.

$<$ https://www3.nhk.or.jp/nhkworld/en/tv/journeys/journey_20160503.html> Choo, Danny. “Ita-Ema.” Culture Japan, 5 Jan 2014. Web. 18 Nov 2017. $<$ http://www.dannychoo.com/en/post/27129/Ita+Ema.html $>$ 
Chun, Jayson. "A New Kind of Royalty: The Imperial Family and the Media in Postwar Japan." Japan Pop: Inside the World of Japanese Popular Culture. Ed. Timothy J. Craig. Armonk: M.E. Sharpe, 2000. 222-224. Print.

Clements, Jonathan. Anime: A History. London: British Film Institute, 2013. Print.

Condry, Ian. The Soul of Anime: Collaborative Creativity and Japan's Media Success

Story. Durham: Duke University Press, 2013. Print.

コリン@C91.2 日目東ナ11b (Corin8187 熟宮神社なう). “らき々改すたが 2003 年 12 月 10 日に連載を開始してから今日で 13 年目に突入です $(・ \forall ・)$ \#らき すた \#鷲宮.” 9 Dec 2016. 21:05, Tweet.

The Constitution of Japan. Chapter III, Article 20.

Czinkota, Michael R., and Ilkka A. Ronkainen. International Marketing. Mason: Thomas Higher Education, 2007. Print.

De Mente, Boye Lafayette. The Japanese Have a Word for It: The Complete Guide to Japanese Thought and Culture. Lincolnwood: Passport Books, 1997. Print. Debating Otaku in Contemporary Japan: Historical Perspectives and New Horizons. Eds. Patrick W. Galbraith, Thiam Huat Kam, and Björn-Ole Kamm. London: Bloomsbury Academic, 2015. Print.

DiChristopher, Tom. "Three Publishers Changing the Comic Book Industry." CNBC, 25 Jan 2016. Web. 14 Sep 2017. <https://www.cnbc.com/2016/01/24/comic-bookpublishers-thrive-in-the-industry.html>

Dixon, Scott R. “"Moe Temple' in Tokyo to Woo Anime Geeks with Maid Café.” Rocket News 24, 27 Oct 2013. Web. 23 Apr 2016. 
$<$ http://en.rocketnews24.com/2013/10/27/moe-temple-in-tokyo-to-woo-animegeeks-with-maid-cafe/>

Dore, Ronald P. Shinohata: A Portrait of a Japanese Village. New York: Pantheon Books, 1978. Print.

Dower, John. War Without Mercy: Pacific War, New York: Pantheon Books, 1986. Print.

Driscoll, Mark. "Debt and Denunciation in Post-Bubble Japan: On the Two Freeters." Cultural Critique 65 (2007): 164-187. Print.

Durkheim, Emile. The Elementary Forms of Religious Life. New York: Free Press, 1995. Print.

Earhart, H. Bryon. Japanese Religion: Unity and Diversity. Belmont: Cengage Learning, 2004. Print.

Earhart, H. Byron. Religion in the Japanese Experience: Sources and Interpretations. Encino: Dickenson Publishing Company, 1974. Print.

Eliade, Mircea. The Sacred and the Profane: The Nature of Religion. Trans. Willard R. Trask. Orlando: Harcourt Brace Jovanovich, 1987. Print.

Eliade, Mircea. "The World, the City, the House." Experience of the Sacred: Readings in the Phenomenology of Religion. Eds. Sumner Twiss and Walter Cosner. Hanover: University Press of New England, 1992. 188-199. Print.

Eng, Lawrence. "Strategies of Engagement: Discovering, Defining, and Describing Otaku Culture in the United States." Fandom Unbound: Otaku Culture in a Connected World. Eds. Mizuko Ito, Daisuke Okabe, and Izumi Tsuji. New Haven: Yale University Press, 2012. 85-104. Print. 
"Establishment of the Creative Industries Promotion Office." Ministry of Economy, Trade and Industry. 8 Jun 2010. Web. 31 Jan 2016. $<$ http://www.meti.go.jp/english/press/data/20100608_01.html>

Faiola, Anthony. “Japan's Empire of Cool.” Washington Post, 27 Dec 2003. Web. 13 Oct 2017. <https://www.washingtonpost.com/archive/politics/2003/12/27/japansempire-of-cool/ab1ae69f-756a-487c-8b342823072f342a/?utm term $=.478 \mathrm{~b} 33026 \mathrm{c} 1 \mathrm{~d}>$

Fan Fiction and Fan Communities in the Age of the Internet: New Essays. Eds. Karen Hellekson and Kristina Busse. Jefferson: McFarland, 2006. Print.

Fluekiger, Joyce Burkhalter. "Loving and Serving God: Bhakti, Murtis, and Puja." Everyday Hinduism. West Sussex: Wiley-Blackwell, 2015. Print.

Frédéric, Louis. Japan Encyclopedia. Trans. Käthe Roth. Cambridge: The Belknap Press of Harvard University Press, 2002. Print.

Freedman, Alisa. "Train Man and the Gender Politics of Japanese 'Otaku' Culture: The Rise of New Media, Nerd Heroes and Consumer Communities." Debating Otaku in Contemporary Japan: Historical Perspectives and New Horizons. Eds. Patrick W. Galbraith, Thiam Huat Kam, and Björn-Ole Kamm. London: Bloomsbury Academic, 2015. 129-146. Print.

Fridell, Wilbur M. "A Fresh Look at State Shintō." Journal of the American Academy of Religion 44.3 (1976): 547-561. Print.

“Gackt Lashes Out at Cool Japan: 'Almost No Results of Japanese Culture Exported Overseas.” Japan Today, 6 Jul 2015. Web. 19 Nov 2017. $<$ https://japantoday.com/category/entertainment/gackt-lashes-out-at-cool-japan- 
almost-no-results-of-japanese-culture-exported-overseas>

Galbraith, Patrick W. “Fujoshi: Fantasy Please and Transgressive Intimacy among 'Rotten Girls' in Contemporary Japan.” Signs 37.1 (2011): 211-232. Print.

Galbraith, Patrick W., and Jason G. Karlin. "Introduction: The Mirror of Idols and Celebrity." Idols and Celebrity in Japanese Media Culture. Eds. Patrick W. Galbraith and Jason G. Karlin. New York: Palgrave Macmillan, 2012. 1-34. Print. Galbraith, Patrick W., Thiam Huat Kam, and Björn-Ole Kamm. 'Introduction: 'Otaku' Research: Past, Present and Future.” Debating Otaku in Contemporary Japan: Historical Perspectives and New Horizons. Eds. Patrick W. Galbraith, Thiam Huat Kam, and Björn-Ole Kamm. London: Bloomsbury Academic, 2015. 1-18. Print.

Gannon, Martin J., and Rajnandini Pillai. Understanding Global Cultures: Metaphorical Journeys through 34 Nations, Clusters of Nations, Continents, \& Diversity. Thousand Oaks: SAGE Publications, 2016. 40-42.

“Geek Spending Power: Otaku Business Gives Japan’s Economy a Lift.” Trends in Japan, Web Japan. 30 Aug 2005. Web. 28 Mar 2016. <http://webjapan.org/trends/business/bus050830.html>

“【ご連絡】「MAPLUS ポータブルナビ 2」用音声に池田秀一さんを追加！[[Go renraku] 'mapurasu pōtaburunabi 2'-yō onsei ni ikedashūichi-san o tsuika!]," Maplus Official Website, n.d.. Web. 26 Jul 2016. < http://maplusnavi.jp/index/info/id/49>

Hairston, Marc. "A Cocoon with a View: Hikikomori, Otaku, and Welcome to the NHK." Mechademia 5 (2010): 311-323. Print. 
Hasegawa, Takashi. "Buddhist Temples in Japan are in Crisis.” Toyokeizai Online, 17 Aug 2015. Web. 27 Oct 2017. <http://toyokeizai.net/articles/-/80746>

Hawley, John Stratton. "The Goddess in India: One Goddess and Many, New and Old." Devī: goddesses of India. Eds. John Stratton Hawley and Donna Marie Wulff. Delhi: Motilal Banarsidass Publishing, 1998. 1-28. Print.

Hills, Matthew. Fan Cultures. New York: Routledge, 2013. Print.

Horiguchi, Sachiko. "Hikikomori: How Private Isolation Caught the Public Eye." A Sociology of Japanese Youth: From Returnees to NEETs. Eds. Roger Goodman, Yuki Imoto, and Tuukka Hannu Ilmari. New York: Routledge, 2012. 122-138. Print.

Hornyak, Tim. “Is ‘Pacific Rim’ a Retelling of Japanese Anime ‘Evangelion’?” CNET, 16 Jul 2013. Web. 15 Jul 2017. <https://www.cnet.com/news/is-pacific-rim-aretelling-of-japanese-anime-evangelion/>

Hosokawa, Shuhei, and Hideaki Matsuoka. "Vinyl Record Collecting as Material Practice: The Japan Case." Fanning the Flames: Fans and Consumer Culture in Culture in Contemporary Japan. Ed. William W. Kelly. Albany: State University of New York Press, 2004. 151-168. Print.

Idols and Celebrity in Japanese Media Culture. Eds. Patrick W. Galbraith and Jason G. Karlin. New York: Palgrave Macmillan, 2012. Print.

Iikura-Gross, Ken. “Touring the Real-Life Anohana.” Anime News Network, News, 25 March 2016. Web. 15 July 2017. $<$ http://www.animenewsnetwork.com/feature/2016-03-25/touring-the-real-lifeanohana/.100253> 
Inouye, Rei Okamoto. "Theorizing Manga: Nationalism and Discourses on the Role of Wartime Manga." Mechademia 4: War/Time. Ed. Frenchy Lunning. Minneapolis: University of Minnesota Press, 2009. 20-38. Print.

Ito, Kinko. "A History of Manga in the context of Japanese Culture and Society," The Journal of Popular Culture 38.3 (2005): 456-475. Print.

Ito, Mizuko. "Introduction." Fandom Unbound: Otaku Culture in a Connected World, Eds. Mizuko Ito, Daisuke Okabe, and Izumi Tsuji. New Haven: Yale University Press, 2012. xi-xxxi. Print.

Ito, Satoshi, Jun Endo and Mizue Mori. Shintō: A Short History. Ed. Inoue Nobutaka. Trans. Mark Teeuwen and John Breen. New York: RoutledgeCurzon, 2003. Print. “Japan Counts on Cool Culture.” BBC, 13 Dec 2004. Web. 13 Oct 2017. $<$ http://news.bbc.co.uk/2/hi/business/4092461.stm>

Japan National Tourism Organization website. "Lucky Star (Raki 2 Suta).” JNTO, n.d. Web. 29 Dec 2015. $<$ http://www.jnto.go.jp/eng/indepth/cultural/pilgrimage/rakisuta.html > Jenkins, Henry. Textual Poachers: Television Fans and Participatory Culture. New York: Routledge, 2012. Print.

Johnston, Eric. “Japan's Bubble Economy: Lessons from when the Bubble Burst.” The Japan Times, 6 Jan 2009. Web. 18 Nov 2017. $<$ https://www.japantimes.co.jp/news/2009/01/06/reference/lessons-from-whenthe-bubble-burst/\#.WhGZ4BNSyRs>

“女子が「付き合いたい！」と思うオタク男子の魅力ランキング $[$ Joshi ga 'tsukiaitai!' To omou otaku danshi no miryoku ranking]," Goo Ranking, Goo 
Research, 5 Mar 2013. Web. 13 Oct 2015.

$<$ https://ranking.goo.ne.jp/column/goorank/32355/>

Kam, Thiam Huat. “The Common Sense that Makes the 'Otaku': Rules for Consuming Popular Culture in Contemporary Japan.” Japan Forum 25.2 (2013): 151-173. Print.

Kam, Thiam Huat. "The Common Sense that Makes the 'Otaku': Rules for Consuming Popular Culture in Contemporary Japan.” Japan Forum 25.2 (2013): 151-173. Print.

Kamm, Björn-Ole. “Opening the Black Box of the 1989 Otaku Discourse.” Debating Otaku in Contemporary Japan: Historical Perspectives and New Horizons. Eds. Patrick W. Galbraith, Thiam Huat Kam, and Björn-Ole Kamm. London: Bloomsbury Academic, 2015. 51-70. Print.

神田明神(Kanda_Myoujin). “Kandamyoujin shrine announces adoption of anime character as official mascot." 2 Jan 2015. 10:33 a.m., Tweet.

Kanda Shrine Official Website. “お守り(Amulets).” Kanda Myojin, n.d. Web. 18 Nov 2017. <http://www.kandamyoujin.or.jp/omamori/detail/?id=7>

Kanzaki, Masahide. "History of Magazines in Japan: 1867-1988." The Web Kanzaki, 7 Jul 1996. Web. 14 Jun 2017. <http://www.kanzaki.com/jpress/mag-history.html> Kaziaki, Shundo. "Between Reality and Fiction: Anime Pilgrimage to a Special Place in the Heart." Niponica, 31 Mar. 2017, 18-21. Print.

Keliyan, Maya. “Kogyaru and Otaku: Youth Subcultures Lifestyles in Postmodern Japan.” Asian and African Studies 15.3 (2011): 95-110. Print. 
Kelly, William W. "Introduction: Locating the Fans." Fanning the Flames: Fans and Consumer Culture in Contemporary Japan. Ed. William W. Kelly. Albany: State University of New York Press, 2004. 1-16. Print.

Kelly, William W. "Sense and Sensibility at the Ball Park: What Fans Make of Professional Baseball in Modern Japan." Fanning the Flames: Fans and Consumer Culture in Culture in Contemporary Japan. Ed. William W. Kelly. Albany: State University of New York Press, 2004. 79-106. Print.

Kikuchi, Satoru. "The Transformation and Diffusion of 'Otaku' Stereotypes and the Establishment of 'Akihabara' as a Place-brand.” Debating Otaku in Contemporary Japan: Historical Perspectives and New Horizons. Eds. Patrick W. Galbraith, Thiam Huat Kam, and Björn-Ole Kamm. London: Bloomsbury Academic, 2015. 147-161. Print.

Kinsella, Sharon. Adult Manga: Culture and Power in Contemporary Japanese Society. Honolulu: University of Hawai'i Press, 2000. Print.

Kitagawa, Joseph M. Religion in Japanese History. New York: Columbia University Press, 1990. Print.

Kitagawa, Joseph M. “Three Types of Pilgrimages in Japan.” Experience of the Sacred: Readings in the Phenomenology of Religion. Eds. Sumner B. Twiss and Walter H. Cosner. Hanover: University Press of New England, 1992. 177-187. Print. Kline, Stephen, Nick Dyer-Witherford, and Greig de Peuter. "Pocket Monsters: Marketing in the Perpetual Upgrade Marketplace.” Digital Play: The Interaction of Technology, Culture, and Marketing. Quebec City: McGill-Queen's University Press, 2003. 218-245. Print. 
Kotani, Mari. "Memories of Youth." The Moé Manifesto: An Insider's Look at the Worlds of Manga, Anime, and Gaming. Ed. Patrick W. Galbraith. North Clarendon: Tuttle Publishing, 2014. 30-37. Print.

Koyama, Noboru. Japanese Students at Cambridge University in the Meiji Era, 18681912: Pioneers for the Modernization of Japan. Trans. Ian Ruxton, Morrisville: Lulu Press, Inc., 2004. Print.

Kustritz, Anne. "Slashing the Romance Narrative." The Journal of American Culture 26.3 (2003): 371-384. Print.

Lane, Richard. Images from the Floating World, the Japanese Print, Oxford: Oxford University Press, 1978. Print.

Lebra, Takie Sugiyama. The Japanese Self in Cultural Logic, Honolulu: University of Hawai'i Press, 2004. Print.

Leupp, Gary. Male Colors: The Construction of Homosexuality in Tokugawa Japan. Berkeley: University of California Press, 1995. Print.

Liberatore, Stacy. “The $\$ 2500$ Holographic 'Girlfriend' that can Double as a Virtual PA (and Even Sent ‘I Miss You' Messages When You're Away.” Daily Mail, 19 Dec 2016. Web. 18 Nov 2017. <http://www.dailymail.co.uk/sciencetech/article4049486/The-2500-holographic-girlfriend-double-virtual-PA-send-missmessages-away.html>

Lochtefeld, James G. The Illustrated Encyclopedia of Hinduism: A-M. New York: The Rosen Publishing Group, 2002. Print. 
“Lucky ¿łstar Cast, Fans to Visit Real-Life Shrine.” Anime News Network, 21 Nov 2007.

Web. 23 Apr 2016. < http://www.animenewsnetwork.com/news/2007-11-

21/lucky-star-cast-fans-to-visit-real-life-shrine>

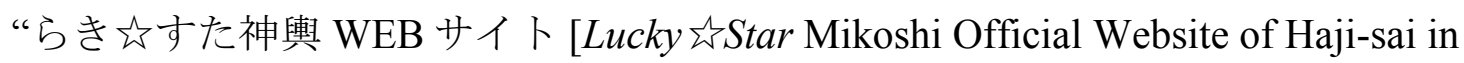

Washinomiya]," LuckyఓStar Mikoshi Preparation Committee, n.d. Web, 28 Sep

2016. $<$ http://luckystar.wasimiya.com/>

Lutgendorf, Philip. “Jaa Santoshi Maa Revisited: On Seeing a Hindu 'Mythological'

Film.” Representing Religion in World Cinema: Filmmaking, Mythmaking,

Culture Making. Ed. S. Brent Plate, New York: Palgrave Macmillan, 2003. 19-42.

Print.

Lutgendorf, Philip. “A 'Made to Satisfaction Goddess': Jai Santoshi Maa Revisited (Part Two)." Manushi 131 (2002): 24-37. Print.

Macias, Patrick, and Tomohiro Machiyama. Cruising the Anime City: An Otaku Guide to Neo Tokyo. Berkeley: Stone Bridge Press, 2004. Print.

Mack, Edward. Manufacturing Modern Japanese Literature: Publishing, Prizes, and the Ascription of Literary Value. Durham: Duke University Press, 2010.

MacWilliams, Mark Wheeler. “Japanese Comic Books and Religion.” Japan Pop: Inside the World of Japanese Popular Culture. Ed. Timothy J. Craig. Armonk: M.E. Sharpe, 2000. 109-137. Print.

MacWilliams, Mark. “Abstract.” Dynamics of Religion: Past and Present: Proceedings of the XXI World Congress of the International Association for the History of Religions. Eds. Christoph Bochinger and Jörg Rüpke. Berlin: Walter de Gruyter GmbH \& Co KG, 2016. Print. 
Masuda, Nozomi. "Shojo Manga and Its Acceptance: What is the Power of Shojo Manga?," International Perspectives on Shojo and Shojo Manga: The Influence of Girl Culture. Ed. Masami Toku, New York: Routledge, 2015. 23-31. Print.

Matsudo, Yukio. "Back to Invented Tradition: A Nativist Response to a National Crisis." Religion and Social Crisis in Japan: Understanding Japanese Society Through the Aum Affair. Eds. Robert Kisala and Mark Mullins. New York: Palgrave, 2001. 163-177. Print.

Matsumoto, David Ricky. “The Face of Emotion in Japan, II: Culture-Specific Aspects and Display Rules." Unmasking Japan: Myths and Realities about the Emotions of the Japanese. Palo Alto: Stanford University Press, 1996. 42-64. Print.

Matsumoto, Shinya. "Loyal Fans of 2011 Anime Show ‘Anohana' Help Saitama Temple.” Asahi, 2 March 2017. Web. 15 July 2017. $<$ http://www.asahi.com/ajw/articles/AJ201703020010.html >

Matsutani, Minoru. "Girl Idol Group About Mass Exposure, Fans.” The Japan Times, 24 Aug 2010. Web. 25 Jul 2016. $<$ http://www.japantimes.co.jp/news/2010/08/24/reference/girl-idol-group-aboutmass-exposure-fans/\#.WOlxhxLyuRs>

McCarthy, Helen. A Brief History of Manga. East Sussex; Ilex Press, 2014. Print.

McClain, James L. Japan: A Modern History. New York: W.W. Norton \& Company, 2002. Print.

McCurry, Justin. "Tama the Cat: 3,000 Attend Elaborate Funeral for Japan's Feline 
Stationmaster.” The Guardian, 29 Jun 2015. Web. 21 Sep 2017.

$<$ https://www.theguardian.com/world/2015/jun/29/tama-the-cat-3000-attendelaborate-funeral-for-japans-feline-stationmaster>

McGee, Oona. "Kyoto Gakuen University Entices Students with TV Ads Featuring Official Anime Character.” Rocket News 24, 7 July 2015. Web. 27 June 2017. $<$ http://en.rocketnews24.com/2015/07/07/kyoto-gakuen-university-enticesstudents-with-tv-ads-featuring-official-anime-character/>

McGray, Douglas. “Japan’s Gross National Cool.” Foreign Policy 130 (2002): 44-54. Print.

Mead, George Herbert. Mind, Self, and Society: From the Standpoint of a Social Behaviorist. Chicago: University of Chicago, 2009. Print.

Milkias, Paulos. “The North-South Gap: Who is to Blame?" Developing the Global South: A United Nations Prescription for the Third Millennium. New York: Algora Publishing, 2010. 45-68. Print.

Miller, Daniel. A Theory of Shopping. New York: Cornell University Press, 1998. Print. Miller, Laura. “Japan’s Zoomorphic Urge.” ASIANetwork Exchange 17.2 (2010): 69-82. Print.

Miyao, Daisuke. "Before Anime: Animation and the Pure Film Movement in Pre-War Japan.” Japan Forum 14.2 (2002): 191-209. Print.

Mizoguchi, Akiko. "Male-Male Romance by and for Women in Japan: A History and the Subgenres of ‘Yaoi’ Fictions.” U.S.-Japan Women's Journal No. 25 (2003): 4975. Print. 
Moore, Albert. Iconography of Religions: An Introduction. Philadelphia: SCM Press Limited, 1977. Print.

Moore, Natalie Y. "In Hindu Worship, Music is Gift to Gods." Chicago Tribune, 12 May 2006. Web. 18 Nov 2017. <http://articles.chicagotribune.com/2006-0512/news/0605120279_1_hindu-temple-rama-temple-songs $>$

Morikawa,Kaichiro. “おたく/ Otaku/ Geek.” Berkeley: Center for Japanese Studies UC Berkeley. 20 Apr 2012. Web. 13 Oct 2015. $<$ http://escholarship.org/uc/item/5zb9r8cr\#>

Mosbergen, Dominique. "Minami Minegishi, Japanese Pop Star, Shaves Head as Penance for Dating." Huffington Post, 2 Feb 2013. Web. 17 Jul 2016. $<$ http://www.huffingtonpost.com/2013/02/02/pop-star-shaves-head-minamiminegishi-japan_n_2608048.html>

Mullins, M.R. "Secularization, Deprivatization and the Reappearance of 'Public Religion' in Japanese Society.” Journal of Religion in Japan 1 (2012): 61-82.

ナベ(11nabe2013).“今日は、仕事の疲労と今月は出費が多いので休養！でも、家 の用を済ましたあとに自宅から 1 番近いタワーレコードアリオ鷲宮店へ行 きました。そのあとは、熟宮神社に行って聖地巡礼してきました.” 4 Dec 2016. 4:14 a.m. Tweet.

Nagata, Kazuaki. “Exporting Culture Via “Cool Japan.” The Japan Times, 15 May 2012. Web. 9 Jul 2015. $<$ http://www.japantimes.co.jp/news/2012/05/15/reference/exporting-culture-viacool-japan/\#.WOlNmhLyuRs>

Kazuaki Nagata. “Japan’s Anime Pilgrimages Give Untrod Real-World Locales 
Economic Boost.” The Japan Times, 4 Sep 2017. Web. 18 Nov 2017.

$<$ https://www.japantimes.co.jp/news/2017/09/04/reference/japans-anime-

pilgrimages-give-untrod-real-world-locales-economic-boost/\#.WhH8VxNSyRs>

Nakamori, Akio. “'Otaku' Research: The City is Full of 'Otaku.'” Manga Burikko June 1983: 200-201. Print.

Napier, Susan. "Manga and Anime: Entertainment, Big Business, and Art in Japan." Routledge Handbook of Japanese Culture and Society. Eds. Victoria Lyon Bestor, Theodore C. Bestor, and Akiko Yamagata. New York: Routledge, 2011. 226-237. Print.

ナツキン!@にこルビィ!来年受験生! (Natsukin_Anime_).“劇場版のにこにーはや つぱり神だよ补 ": [ Gekijō-ban no ni ko ni ${ }^{-}$wa yappari kamida yo ne].” 19 Jan 2017. 4:14 a.m., Tweet.

“年クリスマス・イヴ（24 日） 嫁との晚餐まとめその 3 [Nen kurisumasu ivu (24nichi) yome to no bansan matome sono 3]." LiveDoor Blog, 25 Dec 2011. Web. 29 Sep 2016.

$<\mathrm{http}: / /$ ceron.jp/url/blog.livedoor.jp/insidears/archives/52514190.html>

"New Twist on Traditions in the Otaku Mecca Akihabara! Fully Illustrated 'Ita-Ema' Will Bring You a Year of Happiness?!.” Tokyo Otaku Mode, Jan 11 2014. Web. 18 Nov 2017. <https://otakumode.com/news/52cc27df637d52606b000522/NewTwist-on-Traditions-in-the-Otaku-Mecca-Akihabara!-Fully-Illustrated$\%$ E2\%80\%9CIta-Ema\%E2\%80\%9D-Will-Bring-You-a-Year-of-Happiness-!> Newtype Moving Pictures Magazine, Volume 6, Number 8, August 2007. Print. 
Nihongi: Chronicles of Japan from the Earliest of Times to A.D. 697. Trans. W.G. Aston. North Clarendon: Tuttle Publishing, 2011. 1-64. Print.

Nye, Joseph. "Propaganda Isn't the Way: Soft Power." International Herald Tribune, 10 Jan 2003. Web. 13 Oct 2017.

$<$ https://www.belfercenter.org/publication/propaganda-isnt-way-soft-power $>$

$\bar{O}$ no Yasumaro. The Kojiki: Records of Ancient Matters. Trans. B.H. Chamberlain, North Clarendon: Tuttle Publishing, 1982. Volume I. Print.

Okada, Toshio, and Kaichiro Morikawa. "Otaku Talk,” moderated by Takashi Murakami. Trans. Reiko Tomii. Japan Society, n.d. Web. 25 Nov 2016. $<$ https://www.japansociety.org/multimedia/articles/otaku_talk>

Okada, Toshio. "The Transition of Otaku and Otaku." Debating Otaku in Contemporary Japan: Historical Perspectives and New Horizons. Eds. Patrick W. Galbraith, Thiam Huat Kam, and Björn-Ole Kamm. London: Bloomsbury Academic, 2015. 163-177. Print.

Okada, Toshio. "Introduction to Otakuology.” Debating Otaku in Contemporary Japan: Historical Perspectives and New Horizons. Eds. Patrick W. Galbraith, Thiam Huat Kam, and Björn-Ole Kamm. London: Bloomsbury Academic, 2015. 89-101. Print.

Ono, Sokyo. Shintō: The Kami Way. Rutland: Tuttle, 1962. Print.

“「オタクっぽい」と感じてしまう男性の格好ランキング ['Otaku ppoi' to kanjite shimau dansei no kakkō ranking].” Goo Ranking, Goo Research, 11 Jan 2008. Web. 13 Sep 2016. $<$ https://ranking.goo.ne.jp/ranking/category/026/otaku_fashion_male/> 
“オタラボ調查、「あの人オタクかも? と思ってしまう行動アンケート」調查結

果公開 / 株式会社 ビジュアルワークス [ Otarabo chōsa, 'ano hito otaku kamo? To omotte shimau kōdō ankēto' chōsa kekka kōkai/ kabushikigaisha bijuaruwākusu].” MMD. Mobile Marketing Data LABO, 21 Jun 2010. Web.14 Sep 2016. <https://mmdlabo.jp/press_release/detail_536.html>

Ōtsuka, Eiji. “Otaku Culture as “Conversion Literature.”” Debating Otaku in Contemporary Japan: Historical Perspectives and New Horizons. Eds. Patrick W. Galbraith, Thiam Huat Kam, and Björn-Ole Kamm. London: Bloomsbury Academic, 2015. xiii-xxix. Print.

Papp, Zilia. “Monsters Reappearing in Great Yokai Wars, 1968-2005.” Fear, Cultural Anxiety, and Transformation: Horror, Science Fiction, and Fantasy Films Remade. Eds. Scott A. Lukas and John Marmysz. Lanham: Lexington Books, 2010. 139-142. Print.

Park, Daniel. "Seichi Junrei - Visiting the Holy Sites of Japanese Anime." METAculture Gurashii, 30 Sep 2016. Web. 18 Nov 2017.<http://www.gurashii.com/seichijunrei-visiting-the-holy-sites-of-japanese-anime/>

Pearce, Susan. "Collecting Reconsidered." Interpreting Objects and Collections. Ed. Susan Pearce. New York: Routledge, 1994. 193-204. Print.

Pechelis, Karen. "Bhakti Traditions." The Continuum Companion to Hindu Studies. Ed. Jessica Frazier. New York: Continuum Publishing, 2011. 107-121. Print. Personal Interview. Nara, Japan. 30 May 2016. Petersen, David. Invitation to Kagura: Hidden Gem of the Traditional Japanese Performing Arts. Morrisville: Lulu Press, 2007. Print. 
Picken, Stuart D.B. Essentials of Shintō: An Analytical Guide to Principal Teachings. Westport: Greenwood Press, 1994. Print.

"Pop Culture," Def.1. OxfordDictionaries.com, Oxford Dictionaries, n.d., Web, 23 June 2017. <https://en.oxforddictionaries.com/definition/pop_culture $>$

Porcu, Elisabetta. "Pop Religion in Japan: Buddhist Temples, Icons, and Branding." Journal of Religion and Popular Culture 26.2 (2014): 157-172.

Power, Natsu Onoda. God of Comics: Osamu Tezuka and the Creation of Post-World War II Manga. Jackson: University Press of Mississippi, 2009. 1-16. Print.

“Promoting ‘Cool Japan.” The Japan Times, 15 Aug 2010. Web. 2 Feb 2016. $<$ https://www.japantimes.co.jp/opinion/2010/08/15/editorials/promoting-cooljapan/\#.WeD1YtOGORs>

“Q\&A,” Association of Shintō Shrines, n.d., Web, 27 Oct 2017. $<$ http://www.jinjahoncho.or.jp/en/faq/>

Radkau, Joachim. Max Weber: A Biography. Trans. Patrick Camiller. Cambridge: Polity, 2011. Print.

Raz, Jacob. Audience and Actors: A Study of Their Interactions in the Japanese Traditional Theater. Leiden: E.J. Brill, 1983. Print.

"Saitama Prefecture: Fans Flock to Real-Life Home of Anime Hero." Around Japan, Asahi, 18 Sep 2007. Web. 13 Apr 2016. $<$ http://www.asahi.com/english/Herald-asahi/TKY200709180058.html>

“Saitama town turns into 'cosplay’ mecca.” The Japan Times, 21 Oct 2010. Web. 23 Nov 2016. < http://www.japantimes.co.jp/news/2010/10/21/national/saitamatown-turns-into-cosplay-mecca/> 
Saitō, Tamaki. Beautiful Fighting Girl. Trans. J. Keith Vincent and Dawn Lawson. Minneapolis: University of Minnesota Press, 2011. Print.

Saitō, Tamaki. "Otaku Sexuality.” Trans. Christopher Bolton. Robot Ghosts and Wired Dreams: Japanese Science Fiction from Origins to Anime. Eds. Christopher Bolton, Istvan Csicsery-Ronay, Jr., and Takayuki Tatsumi. Minneapolis: University of Minnesota Press, 2007. 222-249. Print.

Sansom, George. A History of Japan: 1334-1615. Stanford: Stanford University Press, 1961. Print.

Sato, Toshihiko. "On Magical Girls and Male Fans (Part One)." The Moé Manifesto: An Insider's Look at the Worlds of Manga, Anime, and Gaming. Ed. Patrick W. Galbraith. North Clarendon: Tuttle Publishing, 2014. 46-53. Print.

Schodt, Frederik L. "Reading the Comics." The Wilson Quarterly 9.3 (1985): 57-66. Print.

Schodt, Frederik L. Manga! Manga! The World of Japanese Comics. Tokyo: Kodansha, 1986. Print.

Schodt, Frederik L. Dreamland Japan: Writings on Modern Manga. Berkeley: Stone Bridge Press, 1996. Print.

Schodt, Frederik L. The Astro Boy Essays: Osamu Tezuka, Mighty Atom, and the Manga/Anime Revolution. Berkeley: Stone Bridge Press, 2007. Print.

Schluchter, Wolfgang. "Dialectics of Disenchantment: A Weberian Look at Western Modernity." Max Weber Studies 17.1 (2017): 24-47. Print.

“聖地巡礼.” Twitter Search, n.d. Web. 7 Aug 2017. 
$<$ https:/twitter.com/search?q=\%E8\%81\%96\%E5\%9C\%B0\%E5\%B7\%A1\%E7\% $\mathrm{A} 4 \% \mathrm{BC} \& \mathrm{src}=$ typd $>$

Shen, Lien Fan. "Traversing Otaku Fantasy: Representation of the Otaku Subject, Gaze and Fantasy in Otaku no Video." Debating Otaku in Contemporary Japan: Historical Perspectives and New Horizons. Eds. Patrick W. Galbraith, Thiam Huat Kam, and Björn-Ole Kamm. London: Bloomsbury Academic, 2015. 73-87. Print.

Shigematsu, Setsu. "Dimensions of Desire: Sex, Fantasy and Fetish in Japanese Comics." Themes and Issues in Asian Cartooning: Cute, Mad and Sexy. Ed. J.A. Jent. Bowling Green: Bowling Green State University Popular Press, 1999. 127-163. Print.

Shimazono, Susumu. "State Shintō and Religion in Post-War Japan," The SAGE Handbook of the Sociology of Religion. Eds. James A. Beckford and N.J. Demerath. Thousand Oaks: Sage Publications, 2007. 697-709. Print.

Shintō in History: Ways of the Kami. Eds. John Breen and Mark Teeuwen. Honolulu: University of Hawai`i Press, 2000. Print.

Shirane, Haruo. Envisioning the Tale of Genji: Media, Gender, and Cultural Production. New York: Columbia University Press, 2008. Print.

Shively, Donald H. "Sumptuary Regulation and Status in Early Tokugawa Japan." Harvard Journal of Asiatic Studies 25 (1964): 123-164.

Sinha, Vineeta. Religion and Commodification: 'Merchandizing' Diasporic Hinduism. New York: Routledge, 2011. Print. 
Smyers, Karen Ann. The Fox and the Jewel: Shared and Private Meanings in Contemporary Japanese Inari Worship. Honolulu: University of Hawai‘i Press, 1999. Print.

Snow, Nancy. “Uncool Japan: Japan's Gross National Propaganda.” Metropolis, 8-21 Nov 2013. 30. Print.

Steinhoff, Patricia G. "Japan: Student Activism in an Emerging Democracy." Student Activism in Asia: Between Protest and Powerlessness. Eds. Meredith Leigh Weiss and Edward Aspinall, Minneapolis: University of Minnesota Press, 2012. 57-78. Print.

Stringer, Martin D. "Rethinking Animism: Thoughts from the Infancy of our Discipline." Journal of the Royal Anthropological Institute 5.4 (1999): 541-556. Print.

Sueoka, Daisuke. “痛車乗りに朗報！痛いエンジンオイルが登場 [Itasha-nori ni

rōhō! Itai enjin oiru ga tōjō] ! ,” ASCII, 25 May 2009. Web. 28 Jul 2016. $<$ http://ascii.jp/elem/000/000/421/421525/>

Swami Akhilananda. Hindu Psychology: Its Meaning for the West. London: Routledge, 1999. Print.

Tabuchi, Hiroko. “Popular Cartoon Series Makes Japanese Shrine a Magnet for Fans: Devotees are Mainly Young Men, Who Dress Like the Characters - In Miniskirts." The Wall Street Journal, 30 Jul 2008. Web. 10 Apr 2016. <https://www.wsj.com/articles/SB121737740486095275>

Tamashige, Sachiko. "Seeing Where Shintō and Buddhism Cross." The Japan Times, 16 
May 2013. Web. 19 Nov 2017.

$<$ https://www.japantimes.co.jp/culture/2013/05/16/arts/seeing-where-shinto-andbuddhism-cross/\#.WhH1HhNSyRs>

Tamura, Yoshiro. Japanese Buddhism: A Cultural History. Tokyo: Kosei Publishing, 2000. Print.

転載は許さねえぞ[Tensai wa yurusane e zo](Pakomarunakaiki).“なんか言ってよ 終 わりだろ[nanka itte yo owaridaro?] ?" 5 Apr 2016. 22:48, Tweet.

Thal, Sarah. "Redefining the Gods: Politics and Survival in the Creation of the Modern Kami." Japanese Journal of Religious Studies 29.3/4 (2002): 379-404. Print.

Thapan, Anita Raina. Understanding Ganapati: Insights into the Dynamics of a Cult. New Delhi: Manohar Publishers, 1997. Print.

Thomas, Jolyon Baraka. Drawing on Tradition: Manga, Anime, and Religion in Contemporary Japan. Honolulu: University of Hawai`i Press, 2012. Print.

Thorn, Matthew. "Girls and Women Getting Out of Hand: The Pleasure and Politics of Japan's Amateur Comics Community." Fanning the Flames: Fans and Consumer Culture in Culture in Contemporary Japan. Ed. William W. Kelly. Albany: State University of New York Press, 2004, 169-188. Print.

TOKI. "Perspectives on Japan’s Pleasure Seeking Past: Discovering Ukiyo-E.” TOKI, 20 Feb 2016. Web. 1 Jun 2017. $<$ http://www.toki.tokyo/blogt/2016/2/20/perspectives-on-japans-pleasure-seekingpast-discovering-ukiyo-e>

“Tokyo 2020 Clues: When Japan's PM Dressed Up as Mario.” BBC News, 22 Aug 2016. Web. 20 Nov 2017. <http://www.bbc.com/news/world-asia-37151800> 
Tokyo Reporter Staff. "Kyoto Man Obtained Fake ID for AKB48 'Handshake' Tickets.” Tokyo Reporter, 7 Jan 2016. Web. 20 Jul 2016.

$<$ http://www.tokyoreporter.com/2016/01/07/kyoto-man-obtained-fake-id-cardfor-akb48-handshake-tickets/>

Tsien,Tsuen-Hsuin. Science and Civilisation in China: Volume 5, Chemistry and Chemical Technology, Part I: Paper and Printing. Ed. John Needham. Cambridge: Cambridge University Press, 1985. Print.

Tsutsui, William M. Japanese Popular Culture and Globalization. Ann Arbor: Association for Asian Studies, Inc., 2010. Print.

Turner, Bryan S. "Max Weber and the Spirit of Resentment: The Nietzsche Legacy." Journal of Classical Sociology 11.1 (2011): 75-92. Print.

Turner, John C. "Some Current Issues in Research on Social Identity and SelfCategorization Theories.” Eds. Naomi Ellemers, Russell Spears, and Bertjan Doosje. Social Identity. Oxford: Blackwell, 1999. 6-34. Print.

Turner, Victor, and Edith Turner. Image and Pilgrimage in Christian Culture: Anthropological Perspectives. New York: Columbia University Press, 1978. Print.

Vice Japan. “密着 24 時！願望を突き詰めた部屋 - Otaku Room Photographer.” YouTube, 28 May 2014. Web. 18 Jan 2017. $<$ https://www.youtube.com/watch?v=xIeB8caPjoA $>$

Vincent, J. Keith. “Translator's Introduction - Making it Real: Fiction, Desire and the 
Queerness of the Beautiful Fighting Girl.” Beautiful Fighting Girl. Trans. J. Keith Vincent and Dawn Lawson. Minneapolis: University of Minnesota Press, 2011. xi-xxv. Print.

Watanabe, Hiroyuki. "The Nerdiest Shrine in Japan.” Trans. Lena Oishi. Vice, 26 Jan 2010. Web. 25 Sep 2016. < https://www.vice.com/en_us/article/the-nerdiestshrine-in-japan>

Watanabe, Morio. "Imagery and War in Japan: 1995." Perilous Memories: The AsiaPacific War(s). Eds. T. Fujitani, Geoffrey M. White, and Lisa Yoneyama. Durham: Duke University Press, 2001. 120-151. Print.

Weber, Max. Max Weber on Charisma and Institution Building. Ed. S.N. Eisenstadt. Chicago: University of Chicago Press, 1968. Print.

Weber, Max. The Protestant Ethic and the "Spirit" of Capitalism and other Writings. Trans. Peter Baehr and Gordon. C. Wells. New York: Penguin Books, 2002. Print. Willmann, Anna. "Japanese Illustrated Handscrolls." The Metropolitan Museum of Art, Nov 2012. Web. 18 Nov 2017. $<$ https://www.metmuseum.org/toah/hd/jilh/hd_jilh.htm>

Wood, Christopher. The Bubble Economy: Japan's Extraordinary Speculative Boom of the 80's and the Dramatic Burst of the 90's. New York: Atlantic Monthly Press, 1992. Print.

Yamamoto, J. Isamu. Buddhism, Taoism, and Other Far Eastern Religions. Ed. Alan W. Gomes. Grand Rapids: Zondervan, 1998. 15-30. Print.

Yamanaka Tomomi, "Birth of 'Otaku': Centering on Discourse Dynamics in Manga 
Burikko," Debating Otaku in Contemporary Japan: Historical Perspectives and New Horizons, Eds. Patrick W. Galbraith, Thiam Huat Kam, and Björn-Ole Kamm, London: Bloomsbury Academic, 2015, 35-50. Print.

Yano, Christine R. "Wink on Pink: Interpreting Japanese Cute as It Grabs Global Headlines." The Journal of Asian Studies 68.3 (2009): 681-688. Print.

Yasu, Mariko. "Girl-Group Handshake Fans Push Japanese Music Past U.S.” Bloomberg Technology. Bloomberg, 3 Jul 2013. Web. 20 Jul 2016.

$<$ https://www.bloomberg.com/news/articles/2013-07-03/girl-group-handshakefans-push-japanese-music-past-u-s->

Yusa, Michiko. Japanese Religious Traditions. Upper Saddle River: Prentice Hall Inc., 2002. Print. 


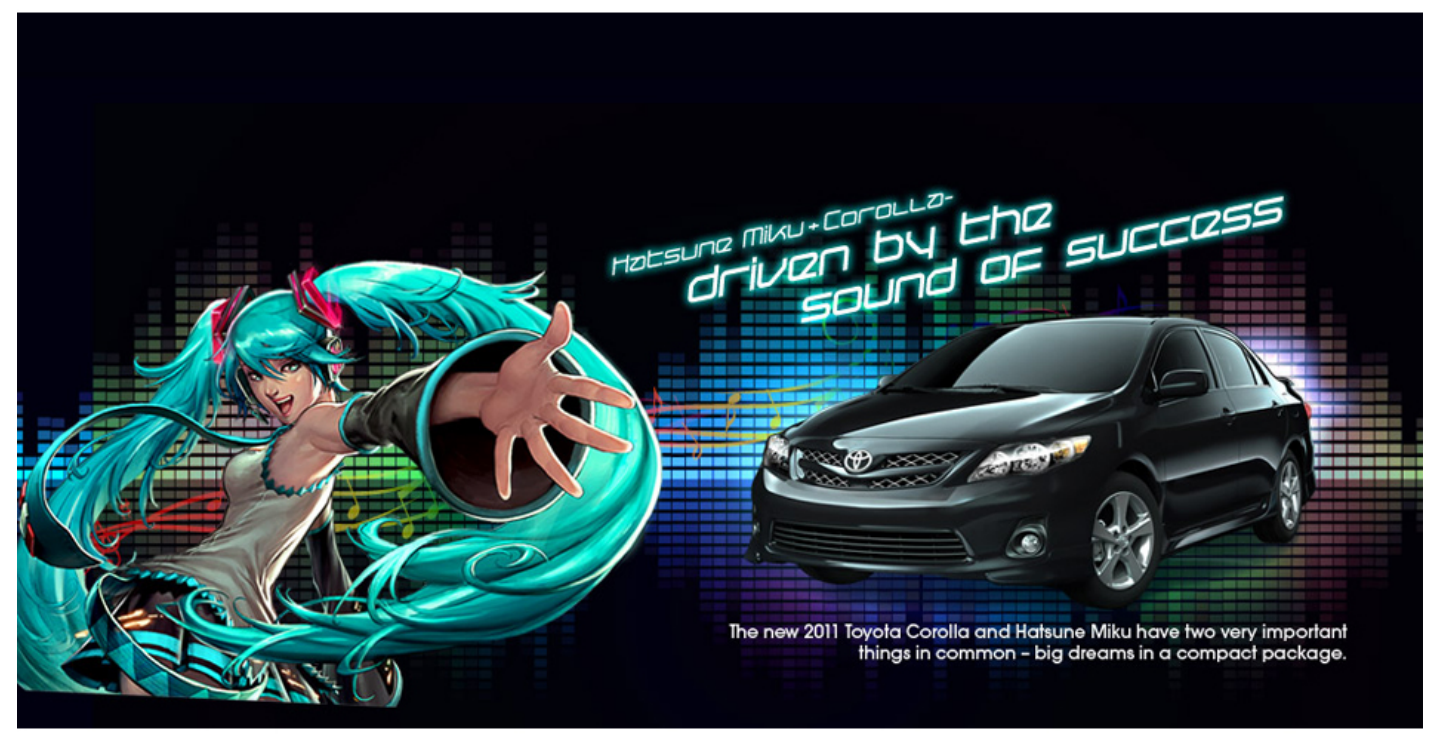

Figure 1.1 Hatsune Miku and 2011 Toyota Corolla. Toyota USA. 2011. Web. 29 Sep 2016. < http://Toyota.com/CorollaMiku>

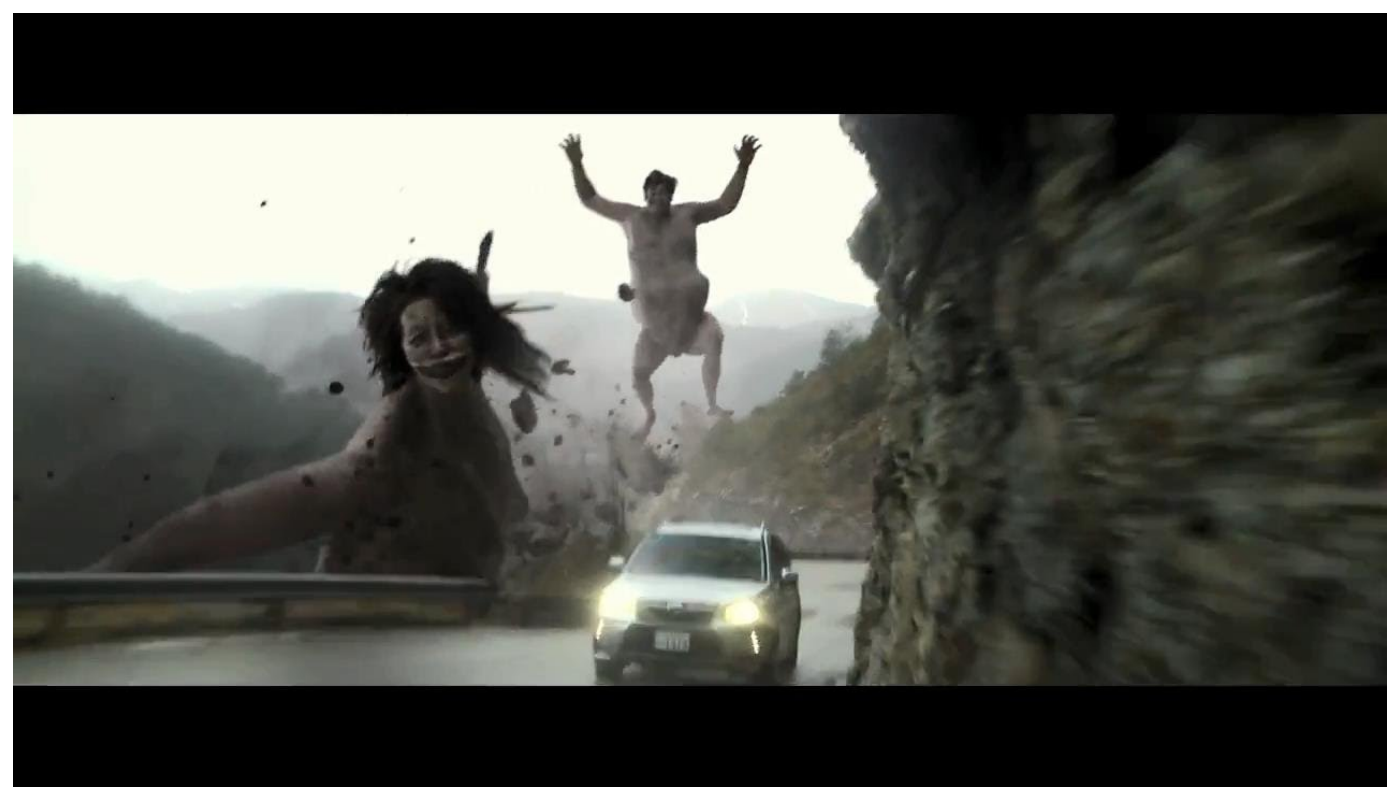

Figure 1.2 Radu, Mihnea. "Attack on Titan: Live-Action Subaru Forester Commercial." Autoevolution. 27 Jan 2014. Web. 26 Aug 2016.

$<$ https://www.autoevolution.com/news/attack-on-titan-live-action-subaru-forester- 
commercial-video-75575.html>

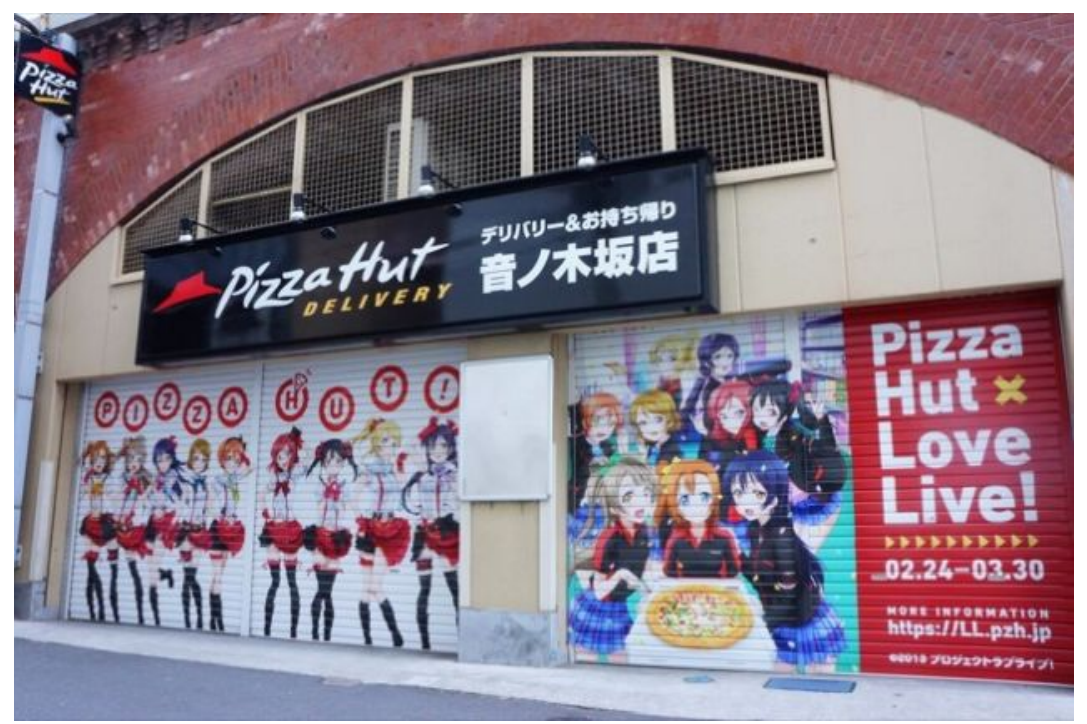

Figure 1.3 “Here's a Japanese Pizza Hut That looks...Different.” Kotaku. 24 Feb 2014. Web. 28 Aug 2016. < http://kotaku.com/heres-a-japanese-pizza-hut-that-looks-different$1529543957>$

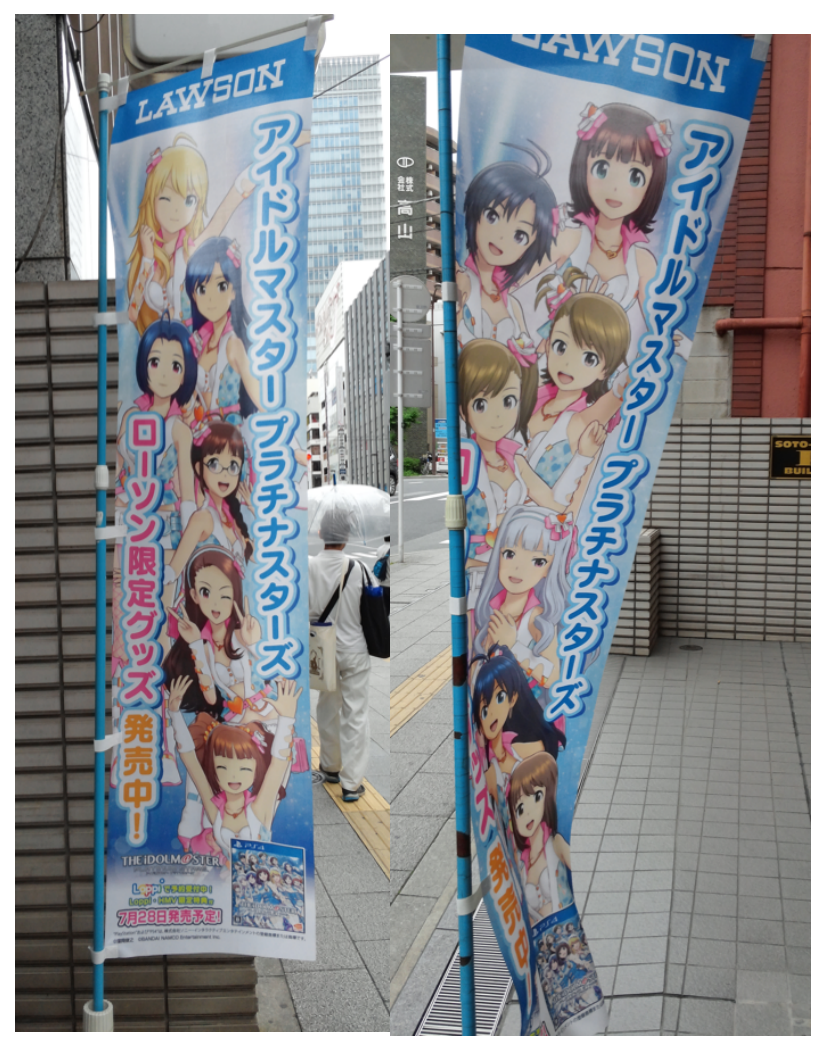

Figure 1.4 Sheehan, Kendra. "The Idolmaster Lawson Banners near Kanda Shrine." 2016. JPEG file. 


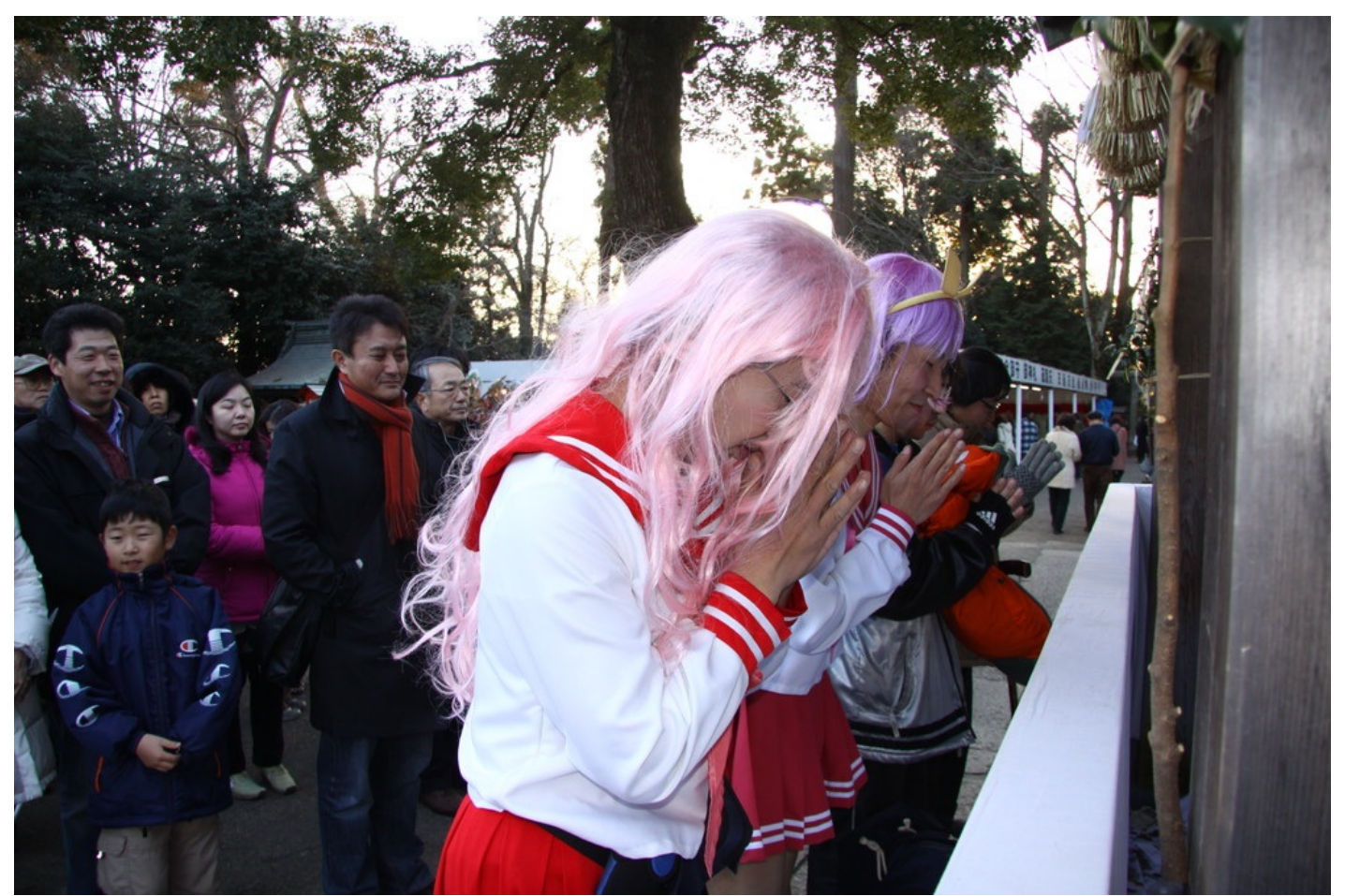

Figure 1.5 Hiroyuki Watanabe, "The Nerdiest Shrine in Japan," translated by Lena Oishi, Vice, 26 Jan 2010, Web, 25 Sep 2016. < https://www.vice.com/en_us/article/the-nerdiestshrine-in-japan>

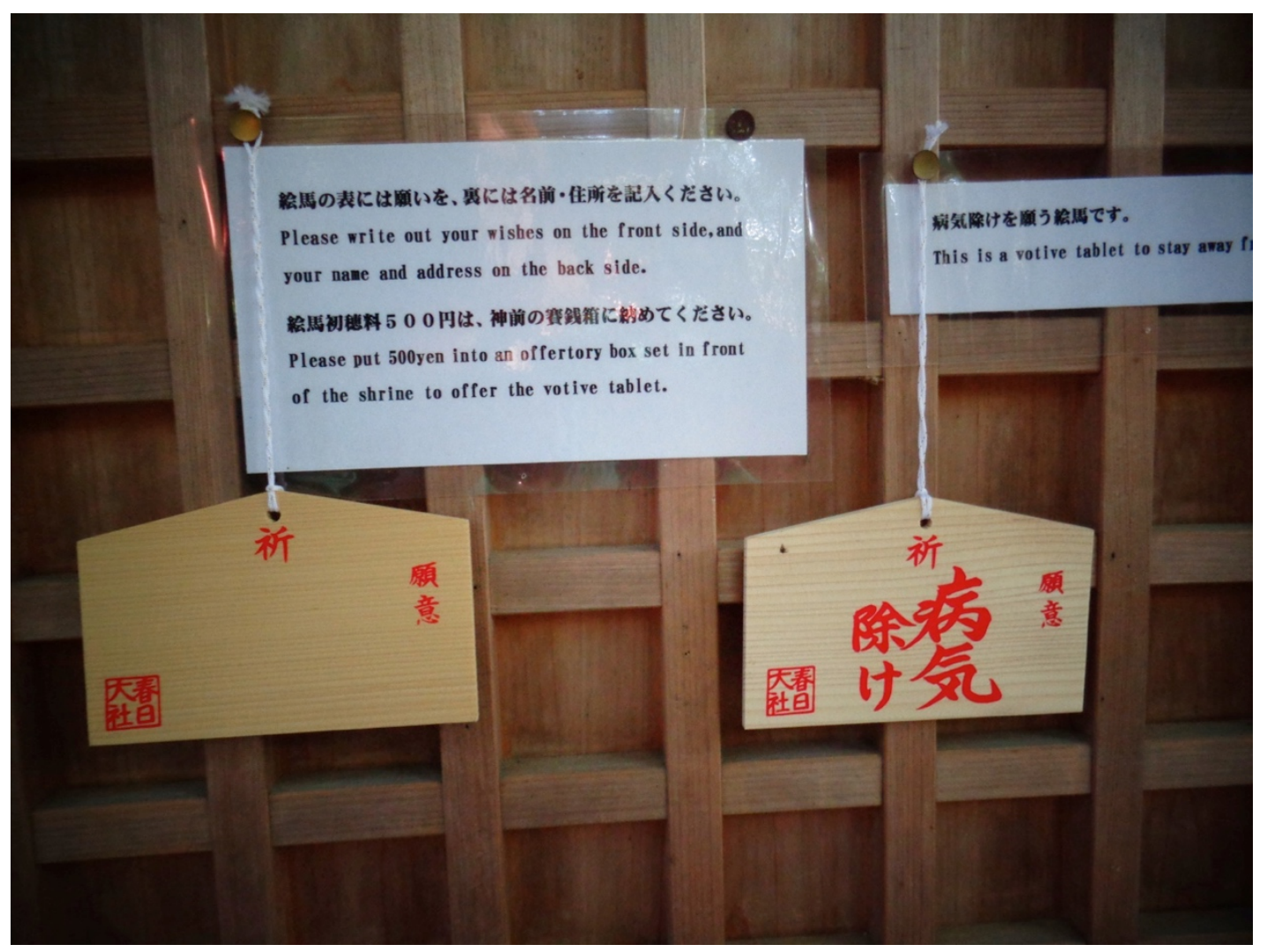

Figure 1.6 Sheehan, Kendra. “Tamukeyama Hachiman-gū Shrine Ema.” 2016. JPEG file. 


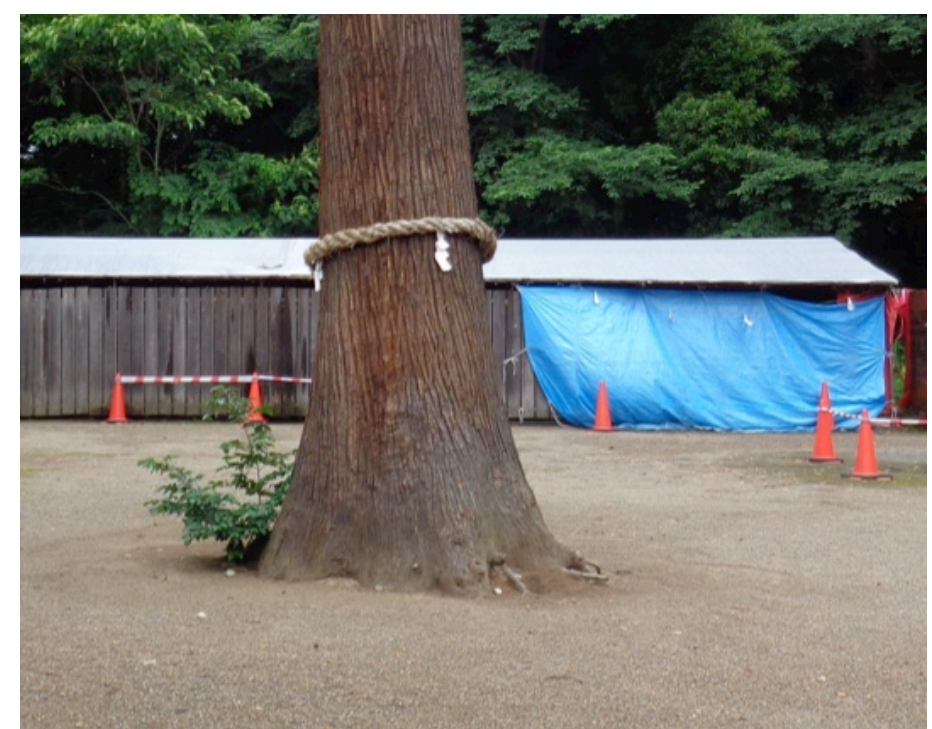

Figure 2.1 Sheehan, Kendra. "Shimenawa at Washinomiya Shrine." 2016. JPEG file.

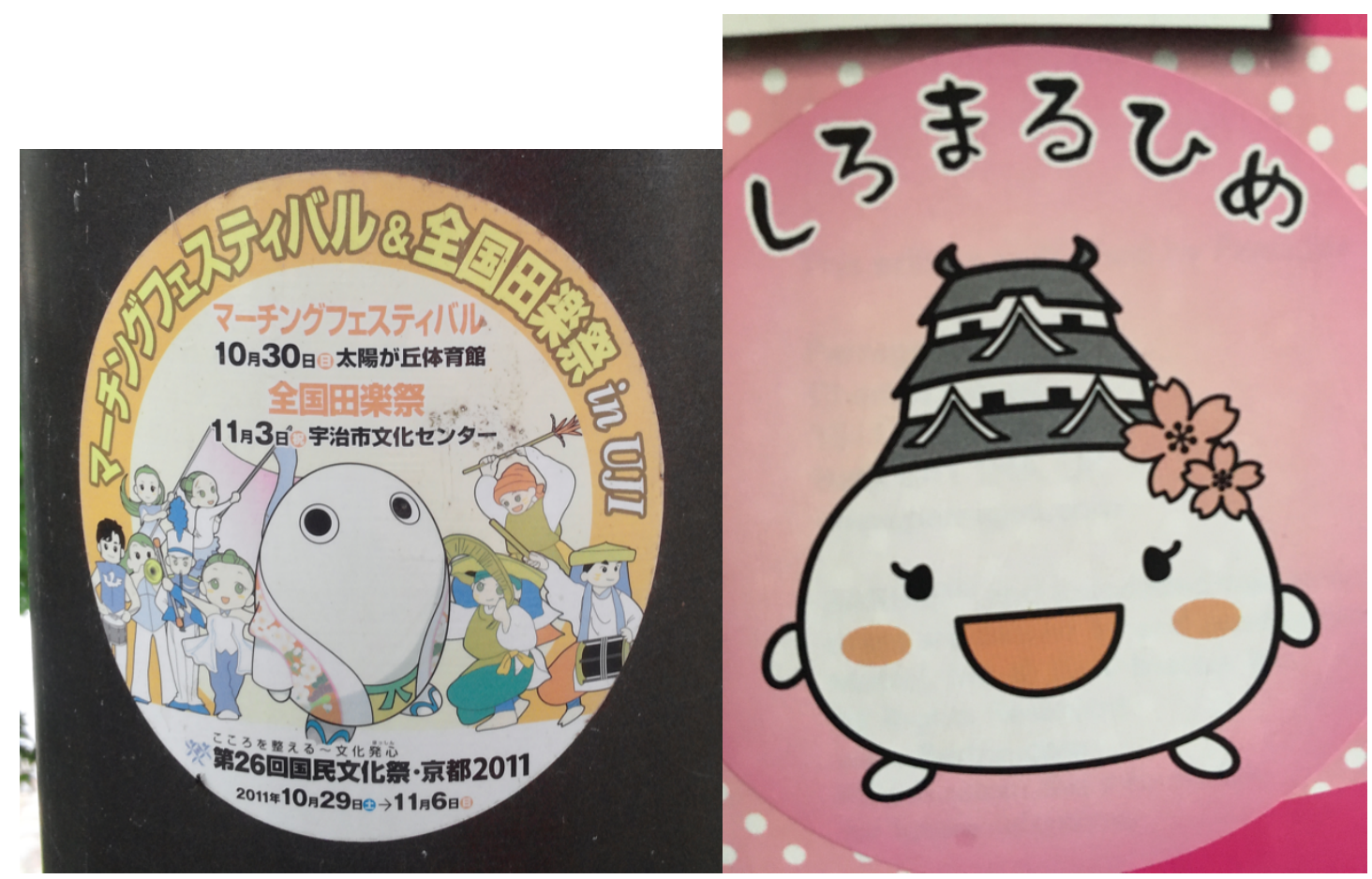

Figure 4.1 Sheehan, Kendra. "City Mascots; Mayumaro (left) and Shiromaru Hime (right)." 2016. JPEG file. 


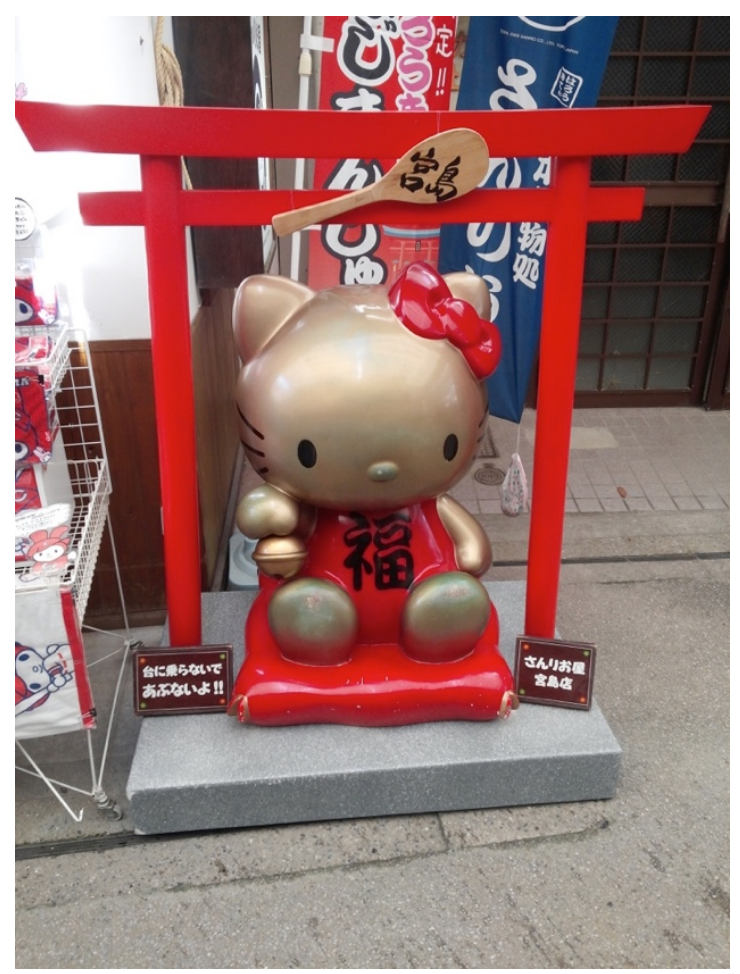

Figure 4.2. Sheehan, Kendra. "Hello Kitty in Shopping Area Outside Itsukushima Shrine." 2016. JPEG file.

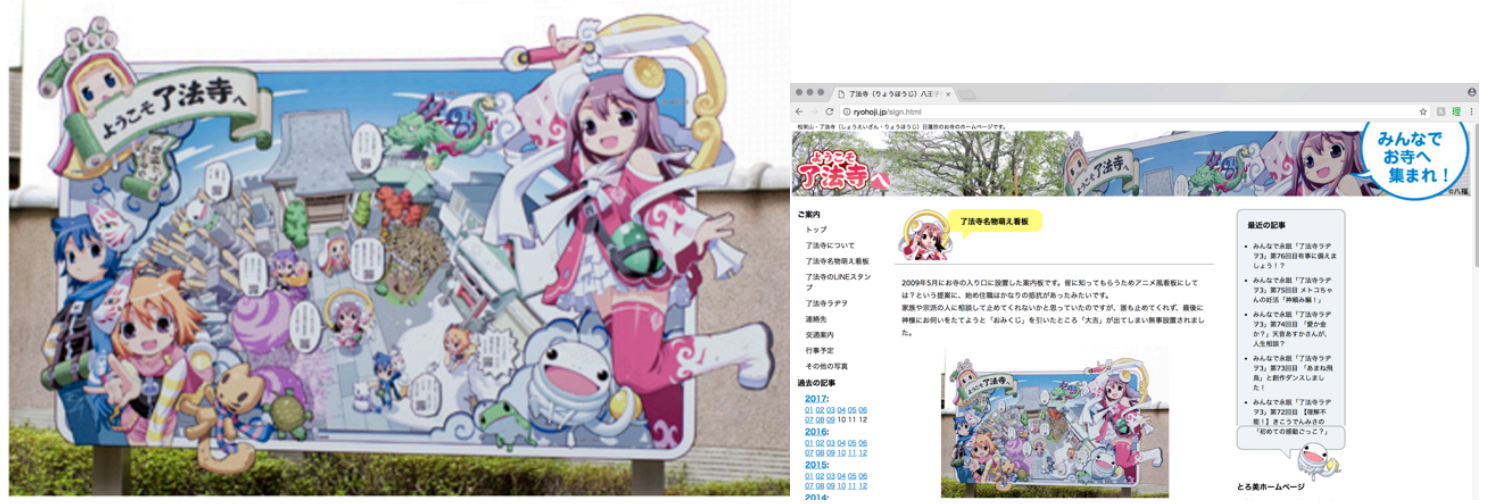

Figure 4.3. “了法寺名物萌え看板 [Ryōhō-ji Special Moe Billboard], Ryōhō-ji Temple Official Website, n.d. Web. 29 Sep 2017. <http://ryohoji.jp/sign.html> 


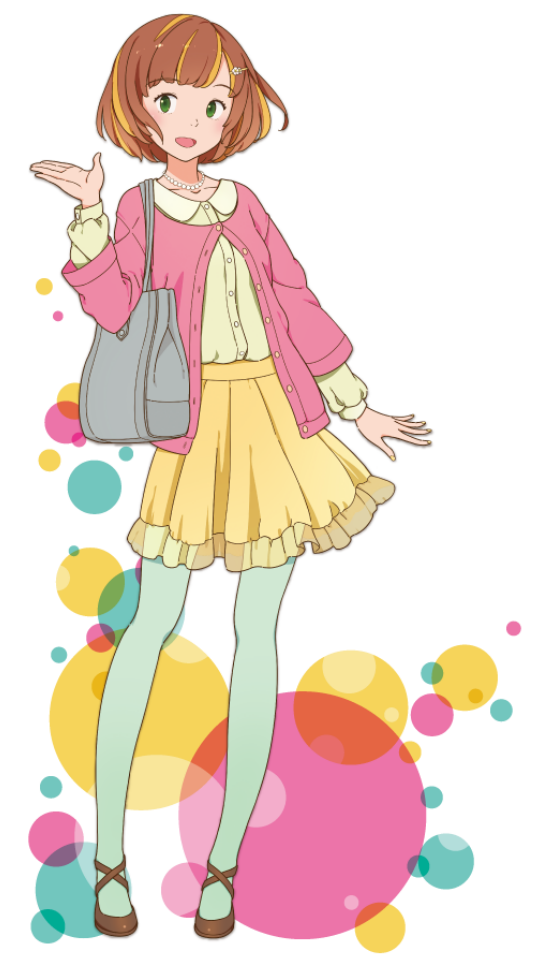

Figure 4.4. "Sono Uzumasa (Kyoto Gakuen University Official Character)," Kyoto Gakuen University, 10 Mar 2016. Web. 29 Sep 2017. $<$ https://www.kyotogakuen.ac.jp/sono>
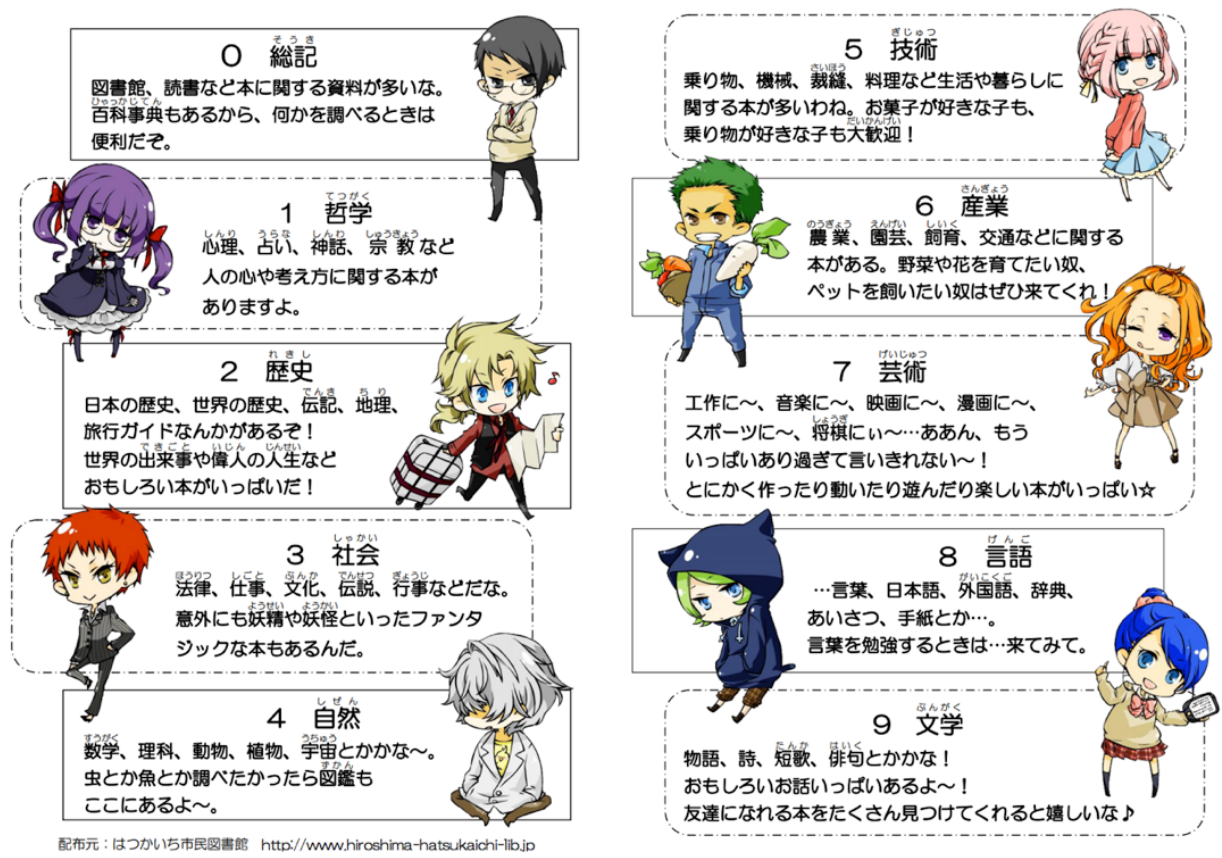

Figure 4.5. "Japan Decimal Classification Method Character Introduction," Hatsukaichi Municipal Library, n.d., Web. 29 Sep 2017. <http:/www.hiroshima-hatsukaichilib.jp/docshp/young.html\#ダウンロード> 


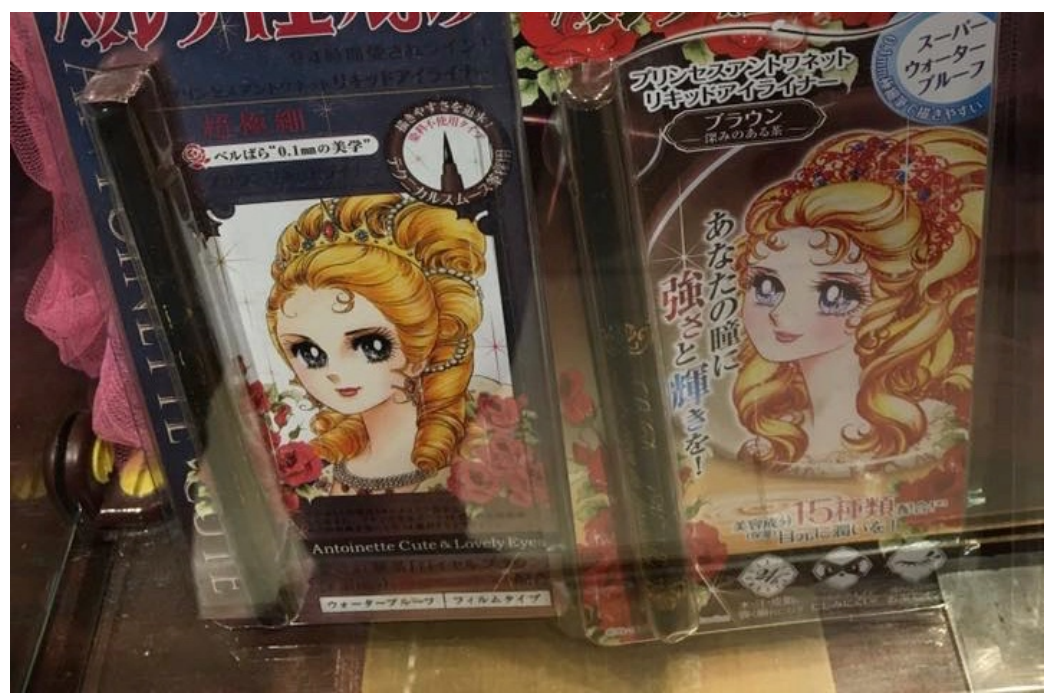

Figure 4.6. Sheehan, Kendra. "Rose of Versailles Mascara in Shop in Nara, Japan.” 2016. JPEG file.

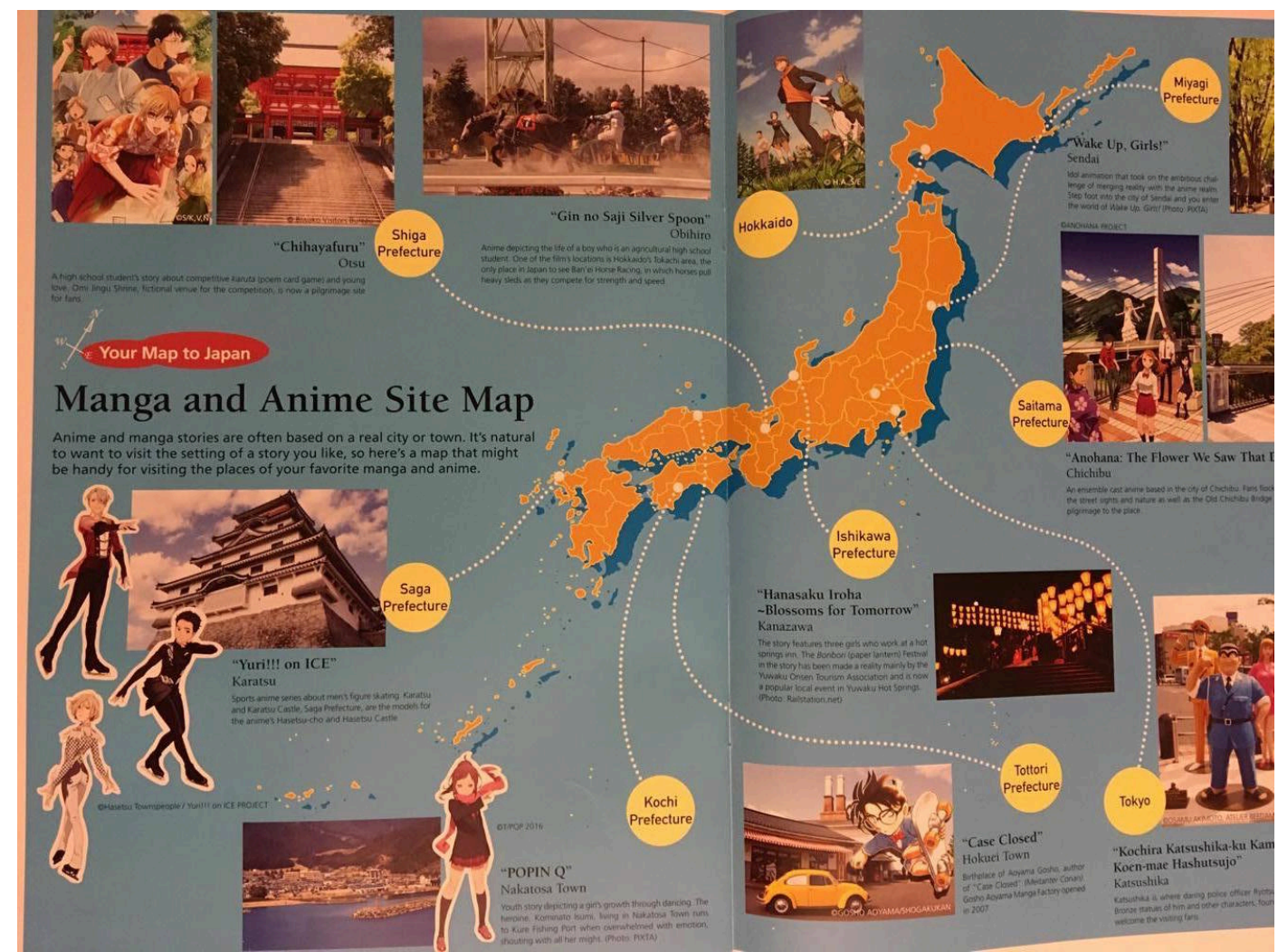

Figure 4.7. Kaziaki, Shundo. "Between Reality and Fiction: Anime Pilgrimage to a Special Place in the Heart." Niponica, 31 Mar 2017, 20-21. 


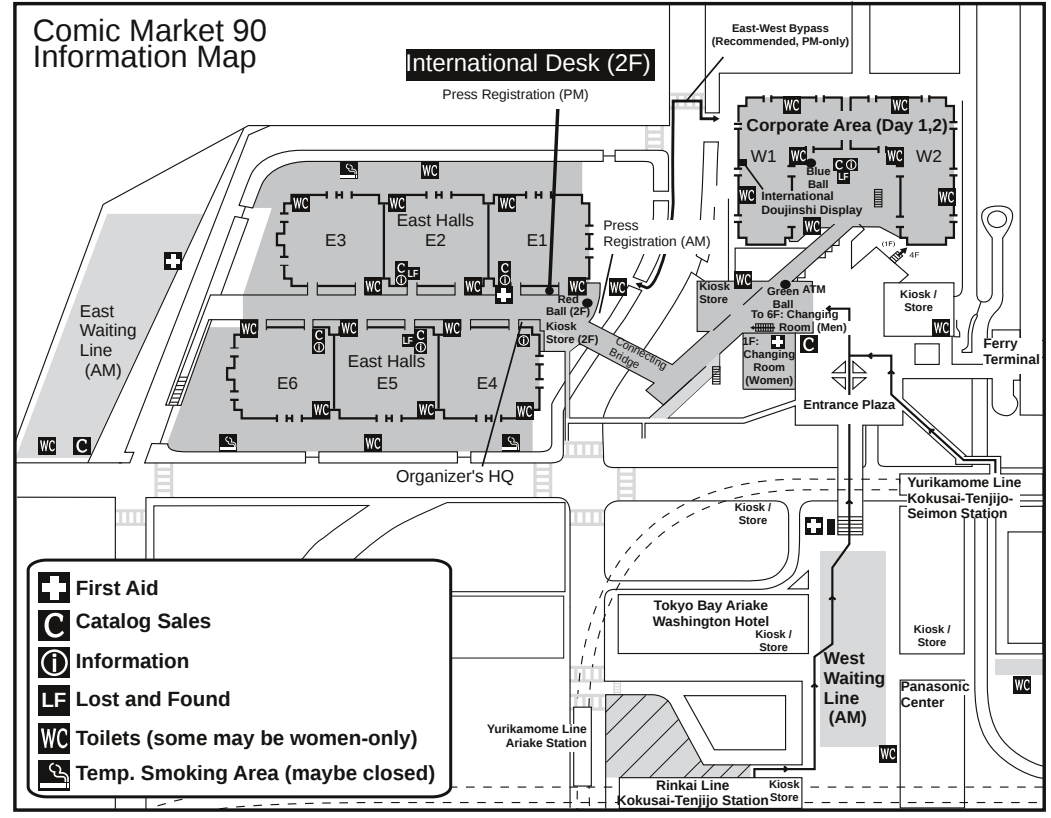

For help in English, German, Chinese or Korean:

Please visit the International Desk (Near the East end of the Connecting Bridge, opposite the Kiosk)

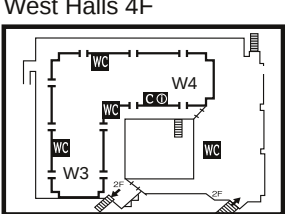

Entrance Plaza 1F

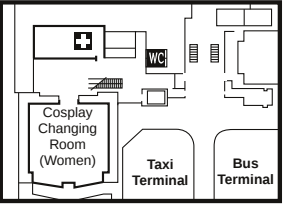

Notes:

- The event starts at 10:00. Please wait in line to get in.

- No parking is available. Please use public transportation

- Beware, the trains towards Tokyo will be very crowded after 16:00.

- For Cosplay, please use the Changing Rooms and register. Do not come or go in Cosplay. - Always ask for permission from cosplayers before taking photos.

- Smoking is only allowed in designated Smoking Areas.

Figure 4.8. Comiket Map PDF. Comiket, Comic Market 90 Information Map. 2016. PDF.

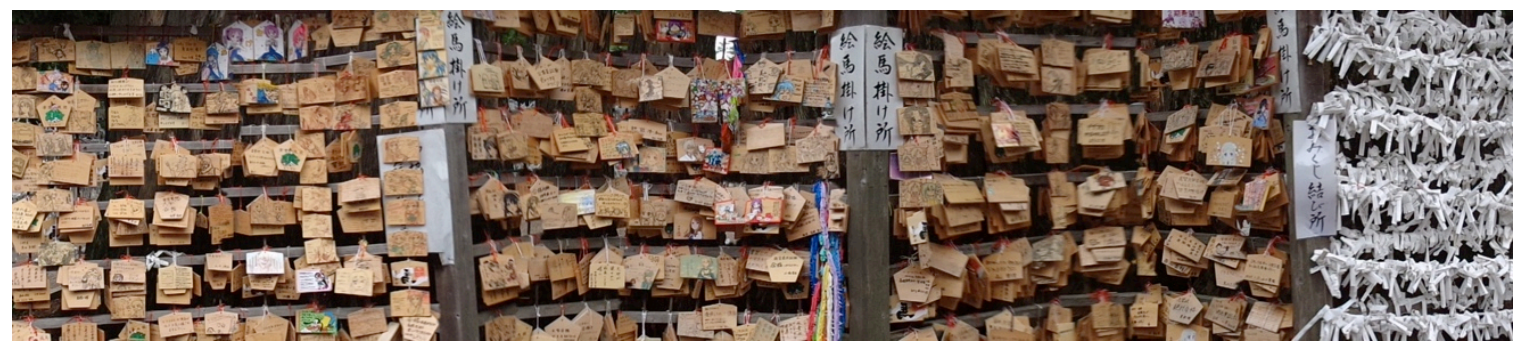

Figure 4.9. Sheehan, Kendra. "Ema and Ita-ema at Washinomiya - pan shot of all three racks.” 2016. JPEG file. 


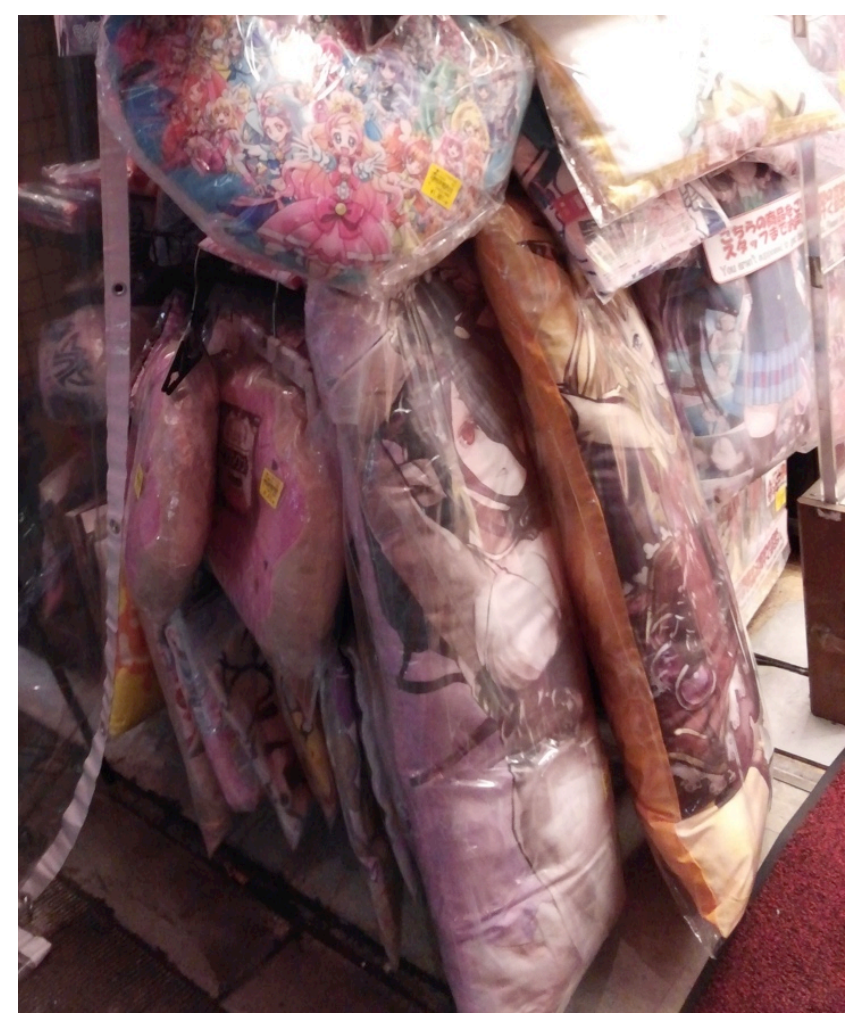

Figure 4.10. Sheehan, Kendra. "Dakimakura in Akihabara.” 2016. JPEG file.

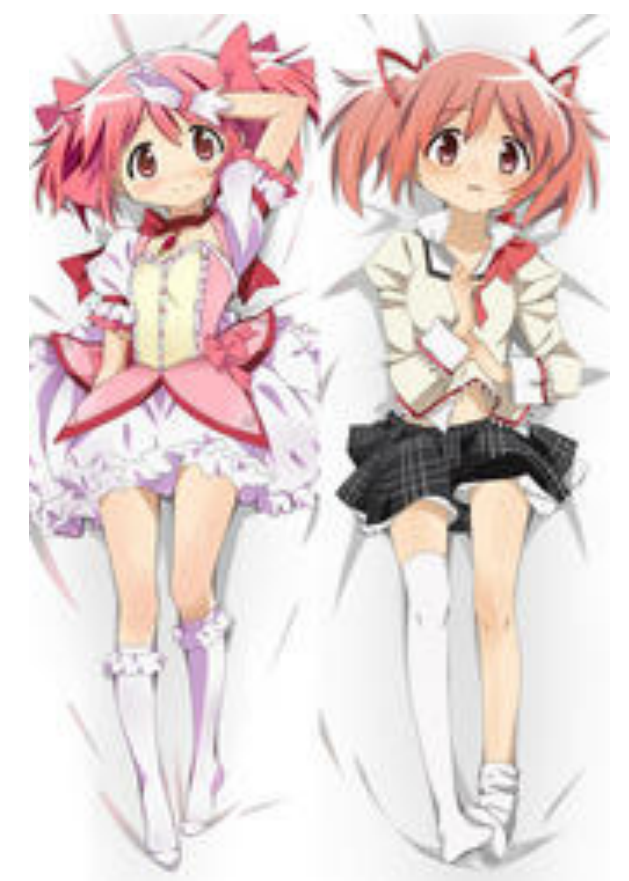

Figure 4.11. Puella Magi Madoka Magica Dakimakura Hugging Body Pillow Cover. Hobby Heart Dakimakura Online Store, n.d. Web. 28 Aug 2016.

$<$ www.hobbyheart.com/puella-magi-madoka-magica-dakimakura-hugging-body-pillowcover-p-2431.html> 


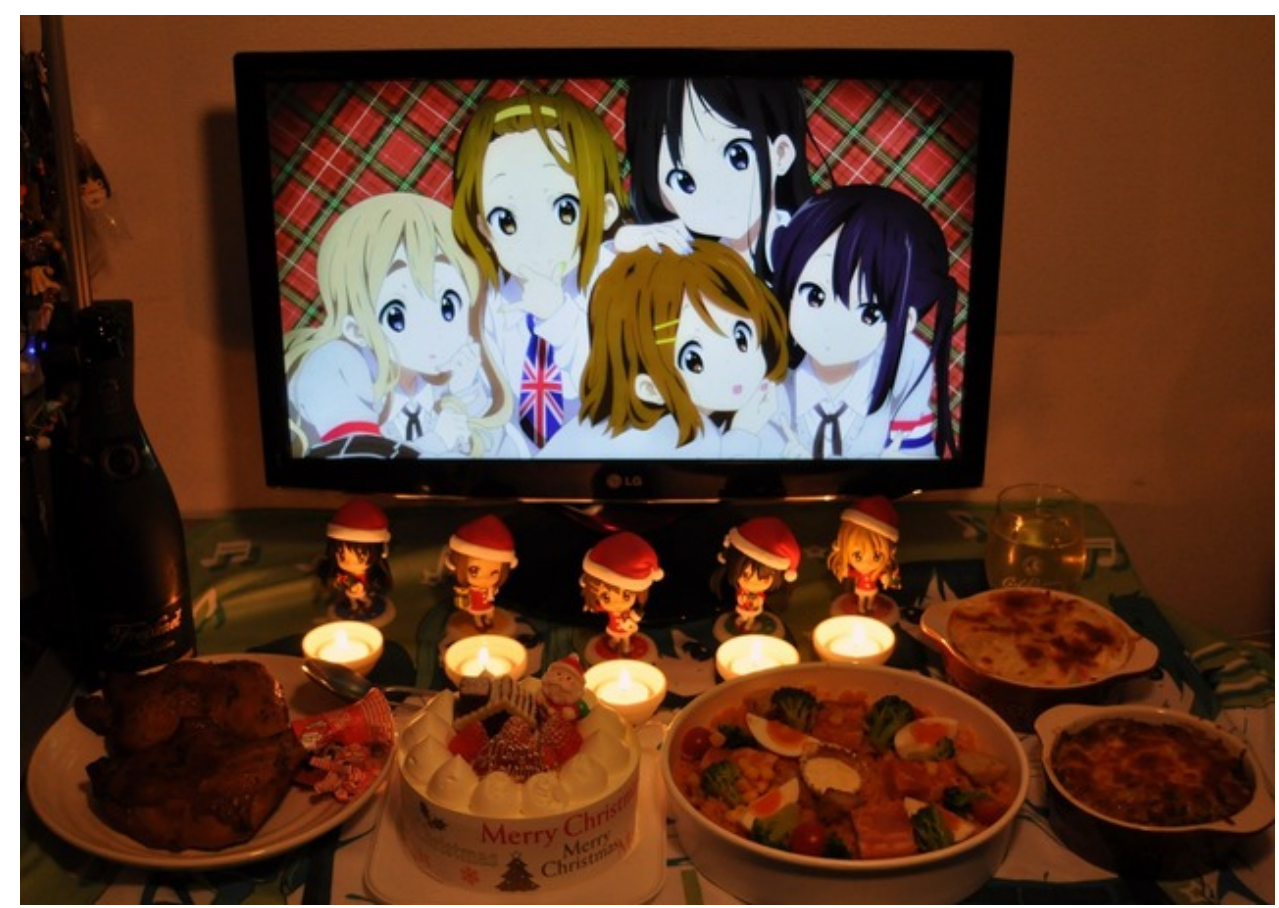

Figure 4.12. Anonymous. ”年クリスマス・イヴ（24日） 嫁との晚餐まとめその 3 [Nen kurisumasu ivu (24-nichi) yome to no bansan matome sono 3]." LiveDoor Blog, 25 Dec 2011. Web. 29 Sep 2016.

$<$ ceron.jp/url/blog.livedoor.jp/insidears/archives/52514190.html> 


\section{海末ちゃん誕生日おめでとう！！！ 俺はこれからも、君を愛し続けていくよ。 \#園田海末生誕祭 \#3月15日は海末ちゃんの誕生日}
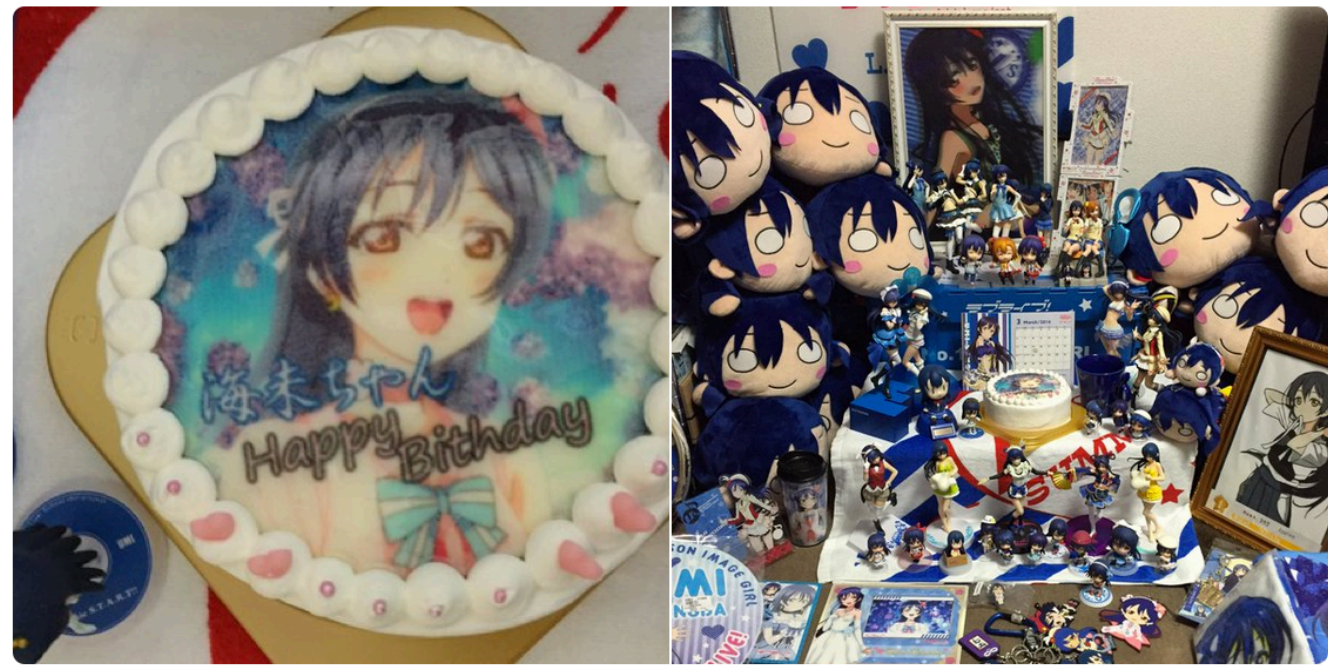

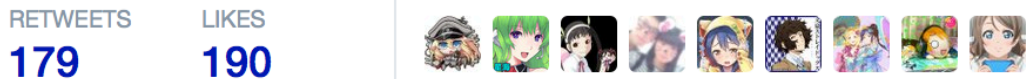

8:00 AM - 14 Mar 2016

ค ㄴ 179 ○ 190 œ

Figure 4.13. Azalea (Azalea01606534). “海未ちゃん誕生日おめでとう！！！俺はこ れからも、君を愛し続けていくよ [Happy Birthday Umi-chan! I will continue to love you in the future]." 14 Mar 2016. 8:00 a.m, Tweet. 


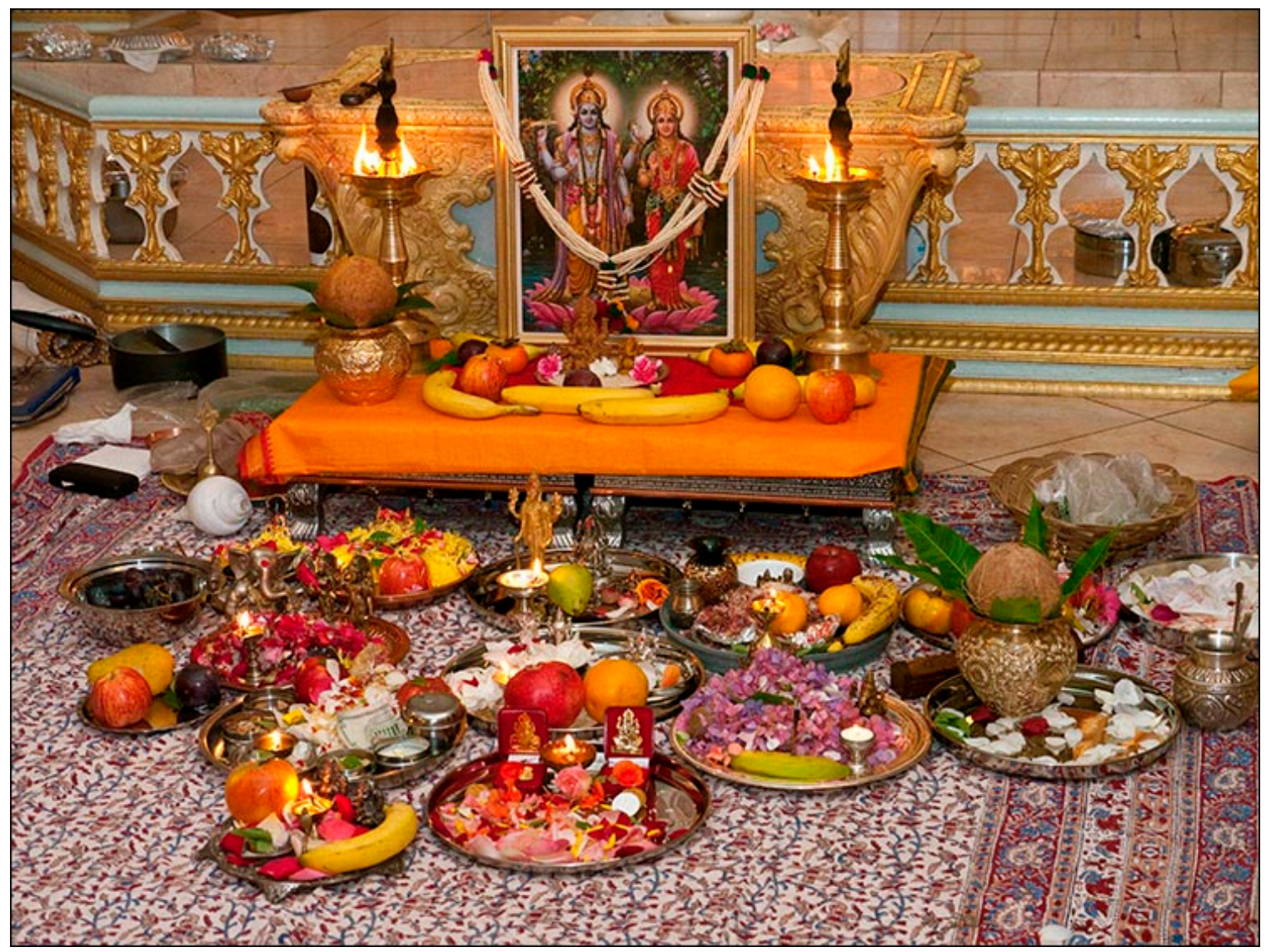

Figure 4.14. "Ways of Worship: Puja and Archana." Sanskrit Religions Institute. 2 Mar 2014. Web. 22 Aug 2016. <sanskrit.org/ways-of-worship-puja-and-archana/>

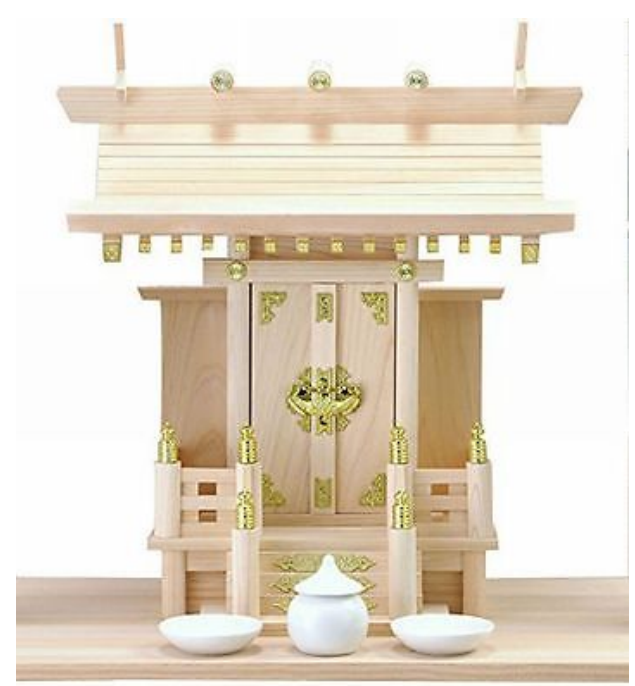

Figure 4.15. Amazon Japan. “神棚 一社.” Amazon Japan. n.d. Web. $<$ www.amazon.co.jp/神棚-一社/dp/B00NAWH3RS > 


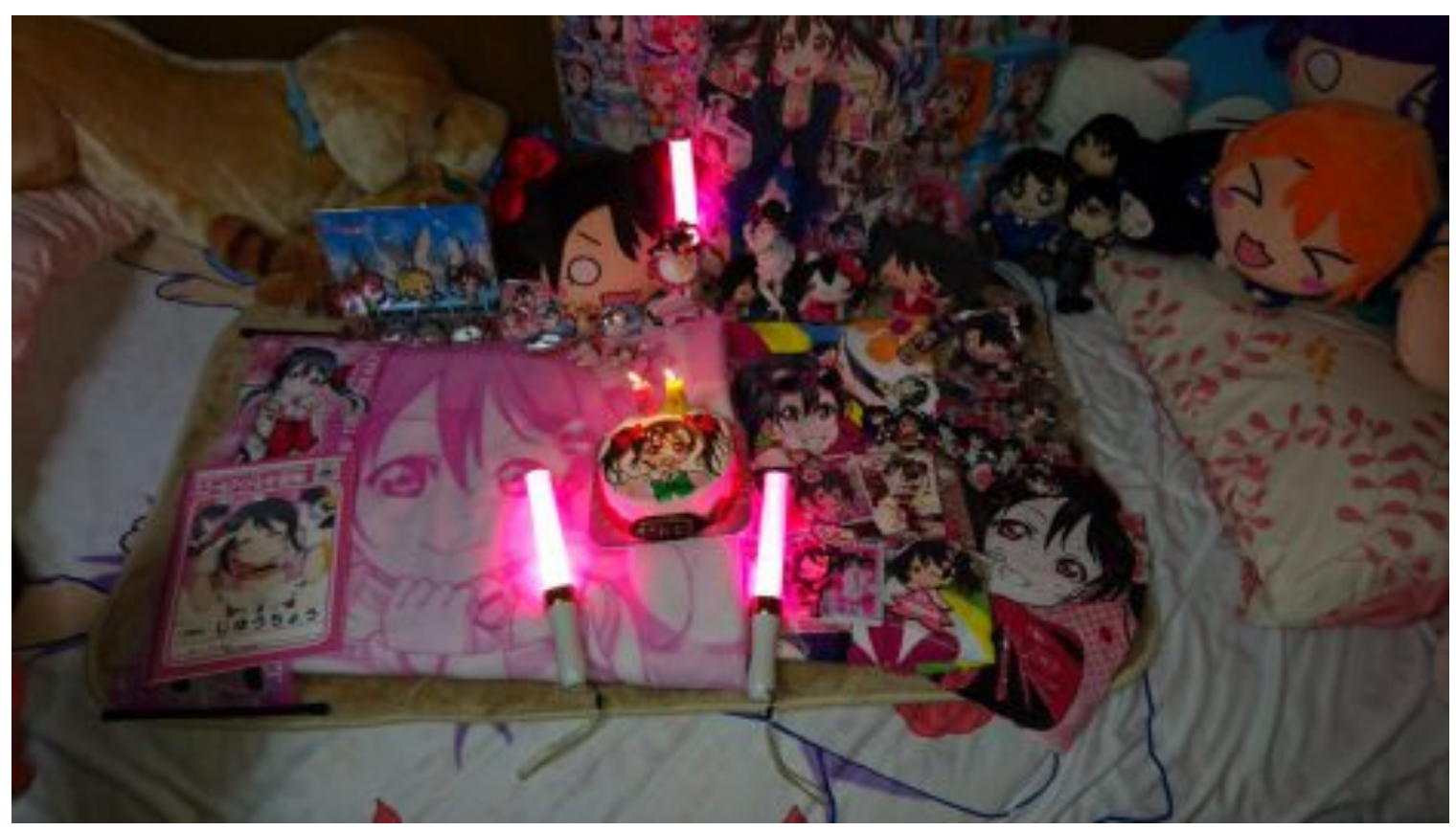

Figure 4.16. "Yazawa Nico's Birthday Still Fondly Remembered." Sankaku Complex. 23 Jul 2016. Web. 25 Aug 2016. <https://www.sankakucomplex.com/2016/07/23/yazawanicos-birthday-still-fondly-remembered/>

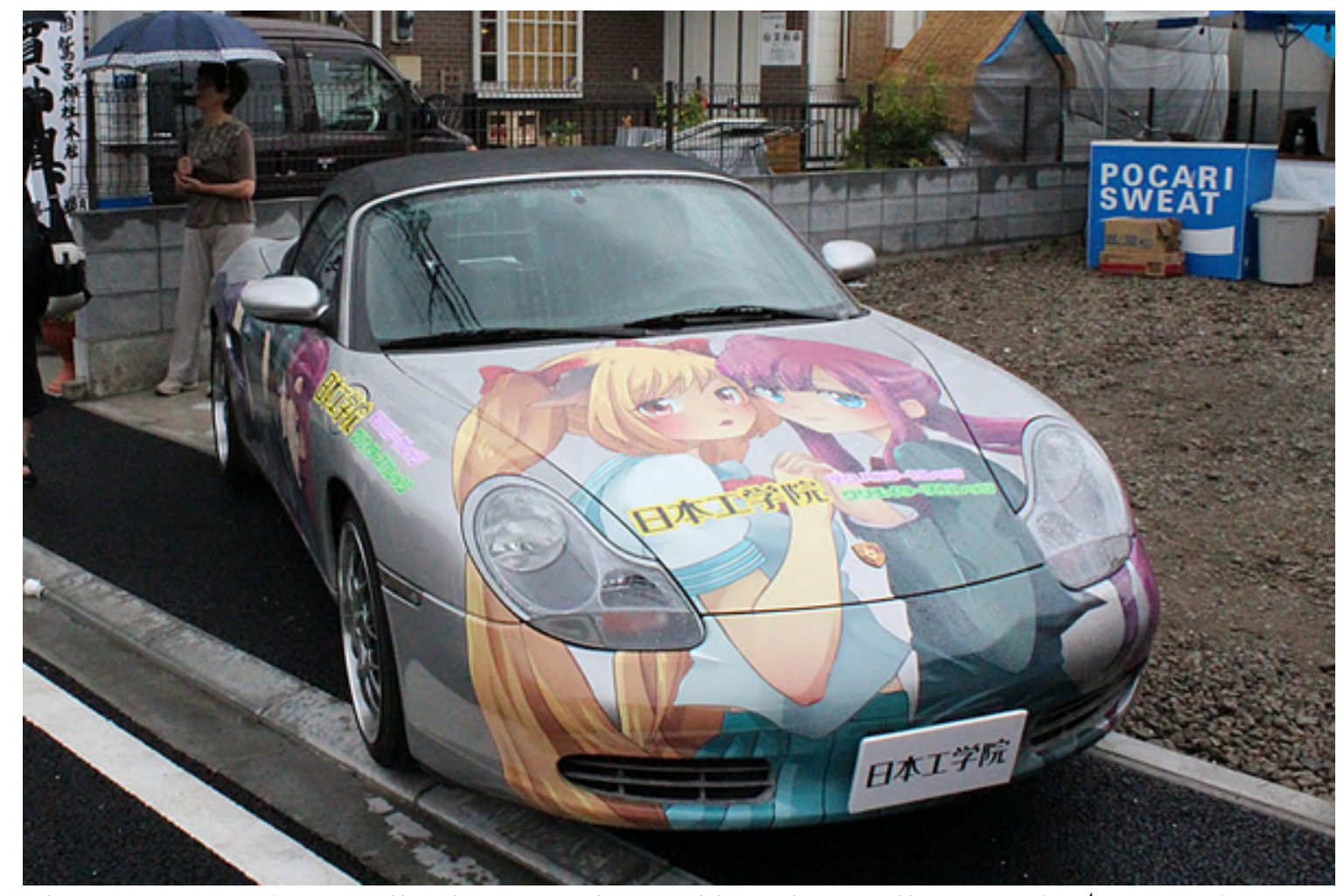

Figure 4.17. Itasha at Haji-sai Matsuri in Washinomiya. Gallery, Lucky ił Star Mikoshi Preparation Committee. 2012. Web. 28 Sep 2016.

$<$ luckystar.wasimiya.com/mikoshi.html> 


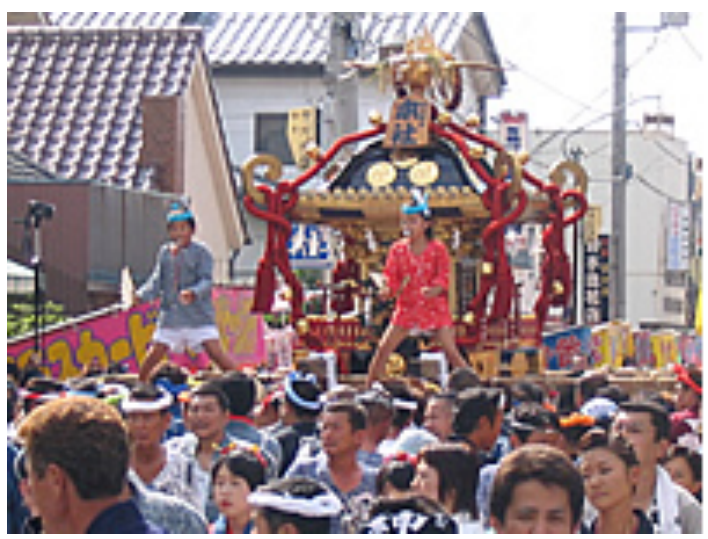

Figure 4.18. Washinomiya Traditional Mikoshi at parade. Mikoshi, Lucky ¿ł Star Mikoshi Preparation Committee. 2012. Web. 28 Sep 2016.

$<$ luckystar.wasimiya.com/mikoshi.html>

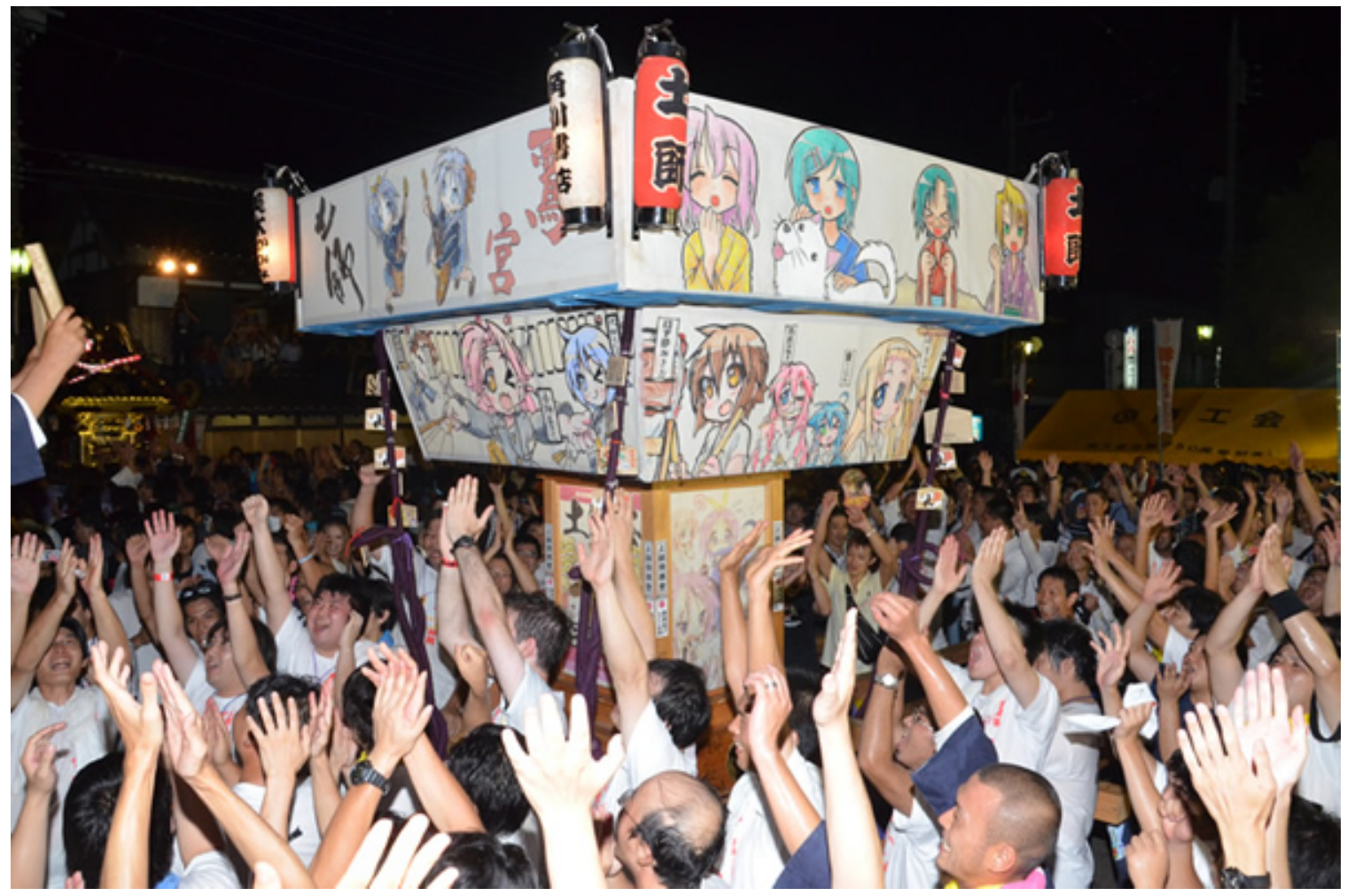

Figure 4.19. Lucky ¿łStar Mikoshi at parade. Gallery, Lucky $\lesssim$ Star Mikoshi Preparation Committee. 2012. Web. 28 Sep 2016. <luckystar.wasimiya.com/mikoshi.html> 


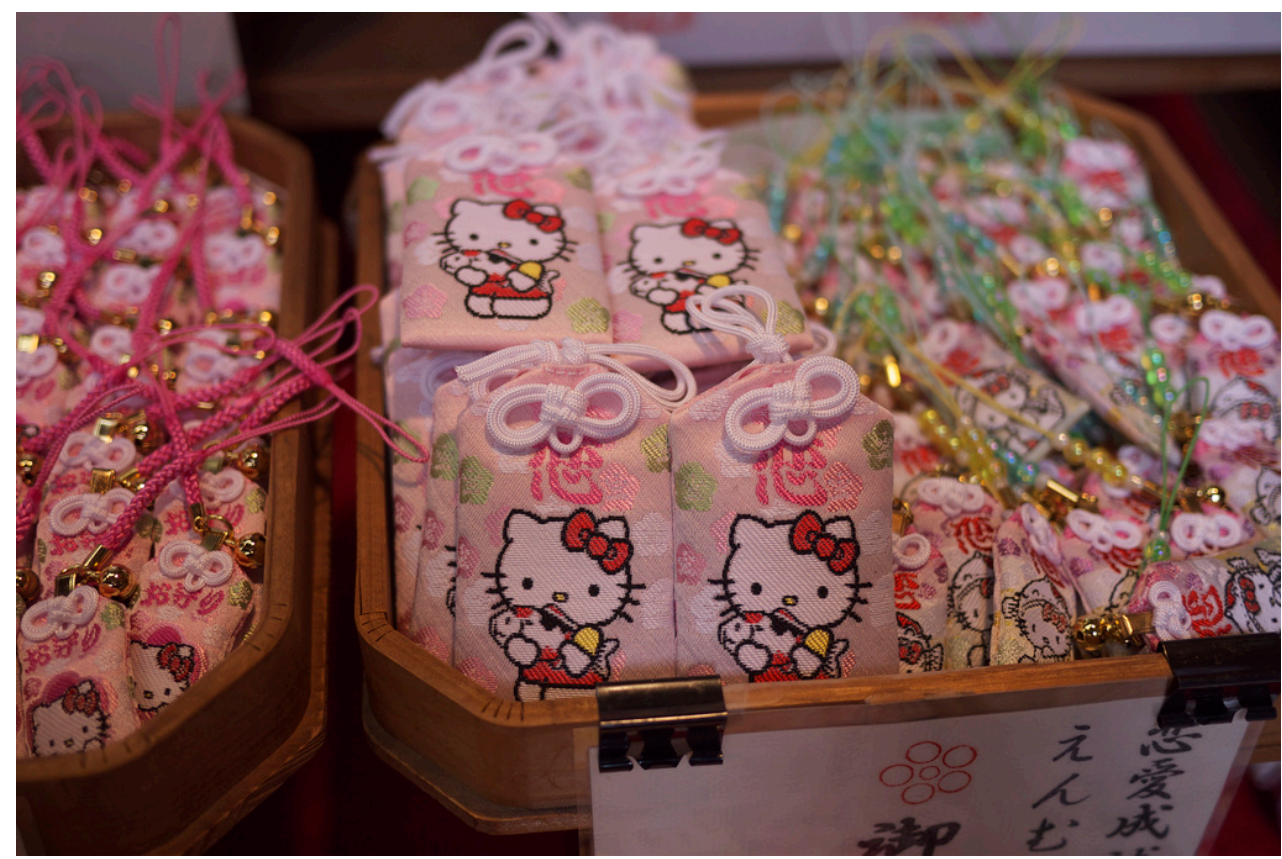

Figure 4.20. Itoh Makiko. "Hello Kitty Omamori (good luck amulets)." Flickr. 17 Mar 2010. Web. 29 Sep 2016. <https://www.flickr.com/photos/makiwi/4539338360>

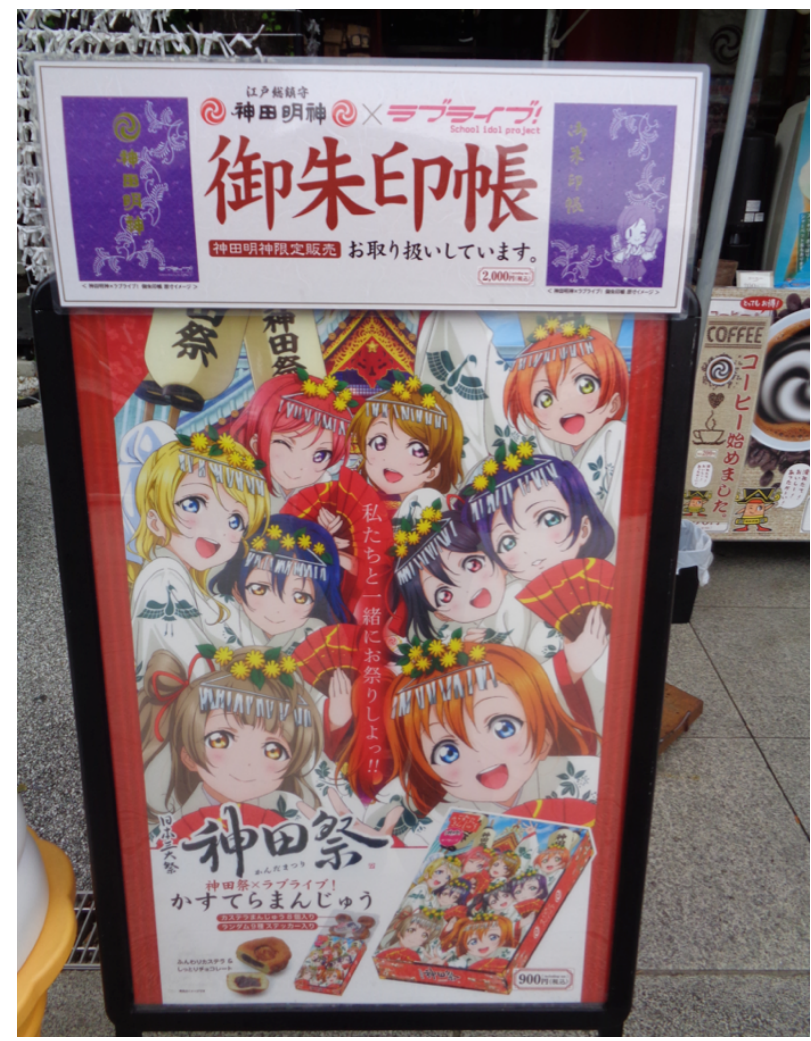

Figure 4.21. Sheehan, Kendra. "Kanda Shrine poster featuring Love Live!" 2016. JPEG file. 


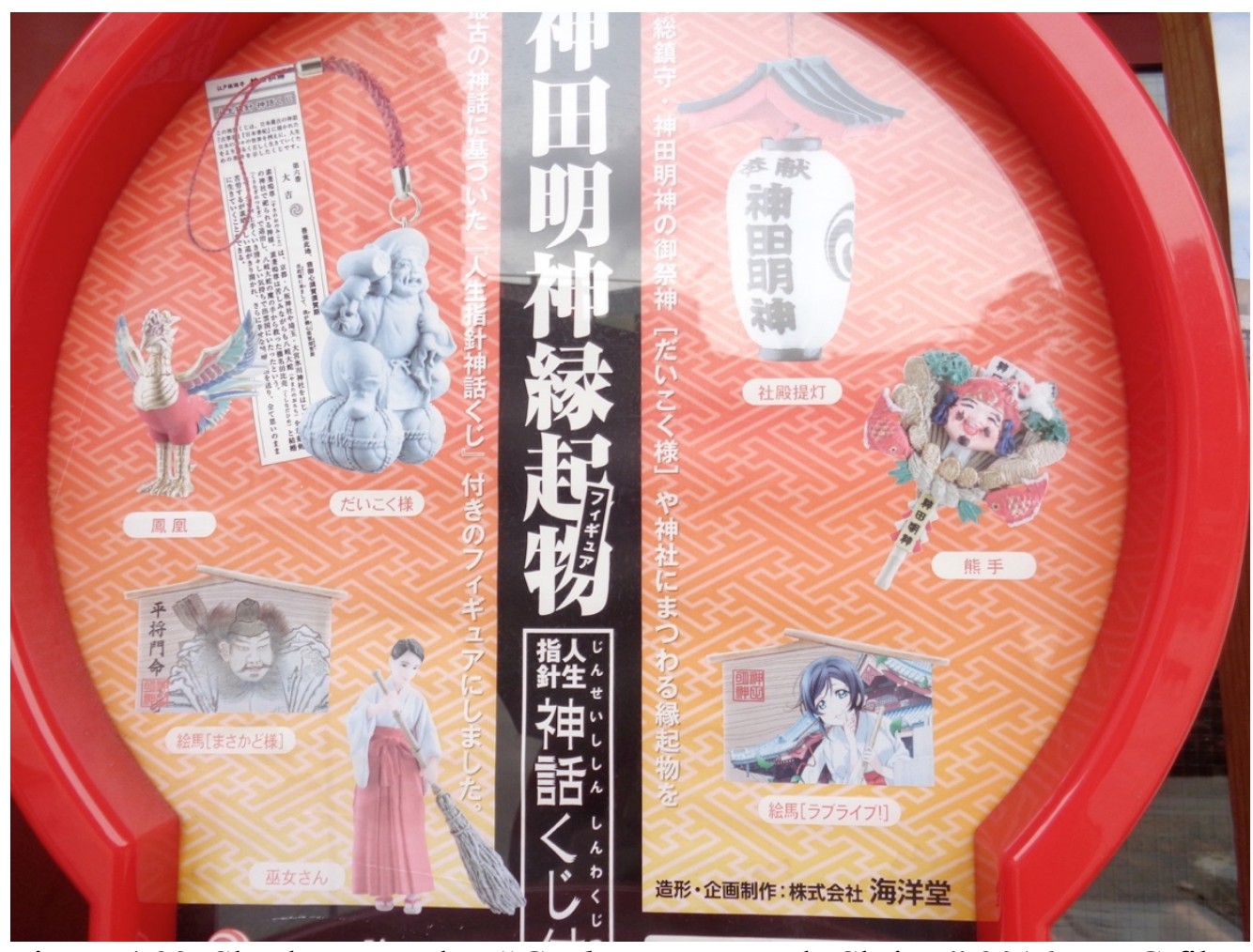

Figure 4.22. Sheehan, Kendra. “Gachapon at Kanda Shrine.” 2016. JPEG file.

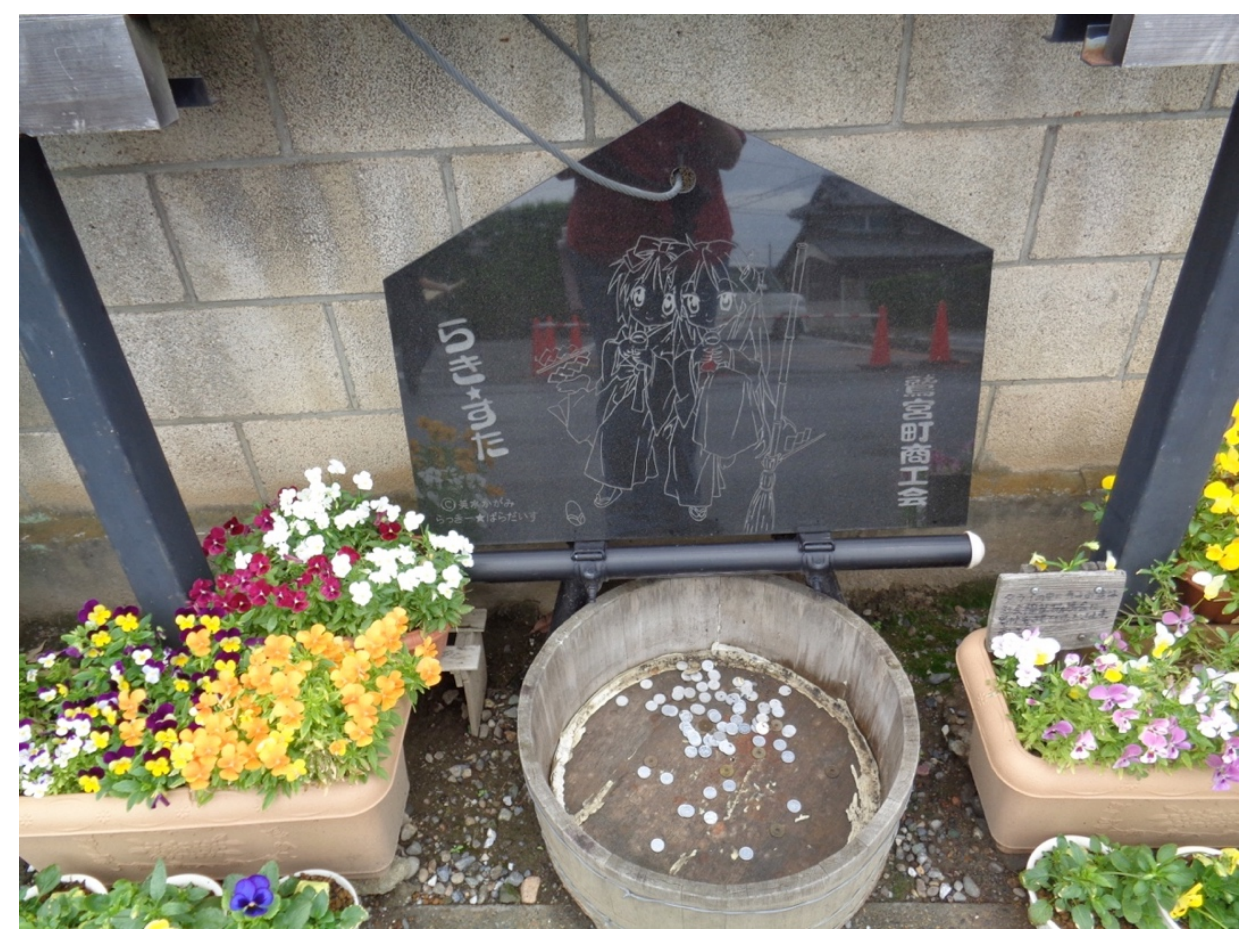

Figure 4.23. Sheehan, Kendra. "Lucky $\underset{\uparrow}{ }$ Star Stone Ema.” 2016. JPEG file. 


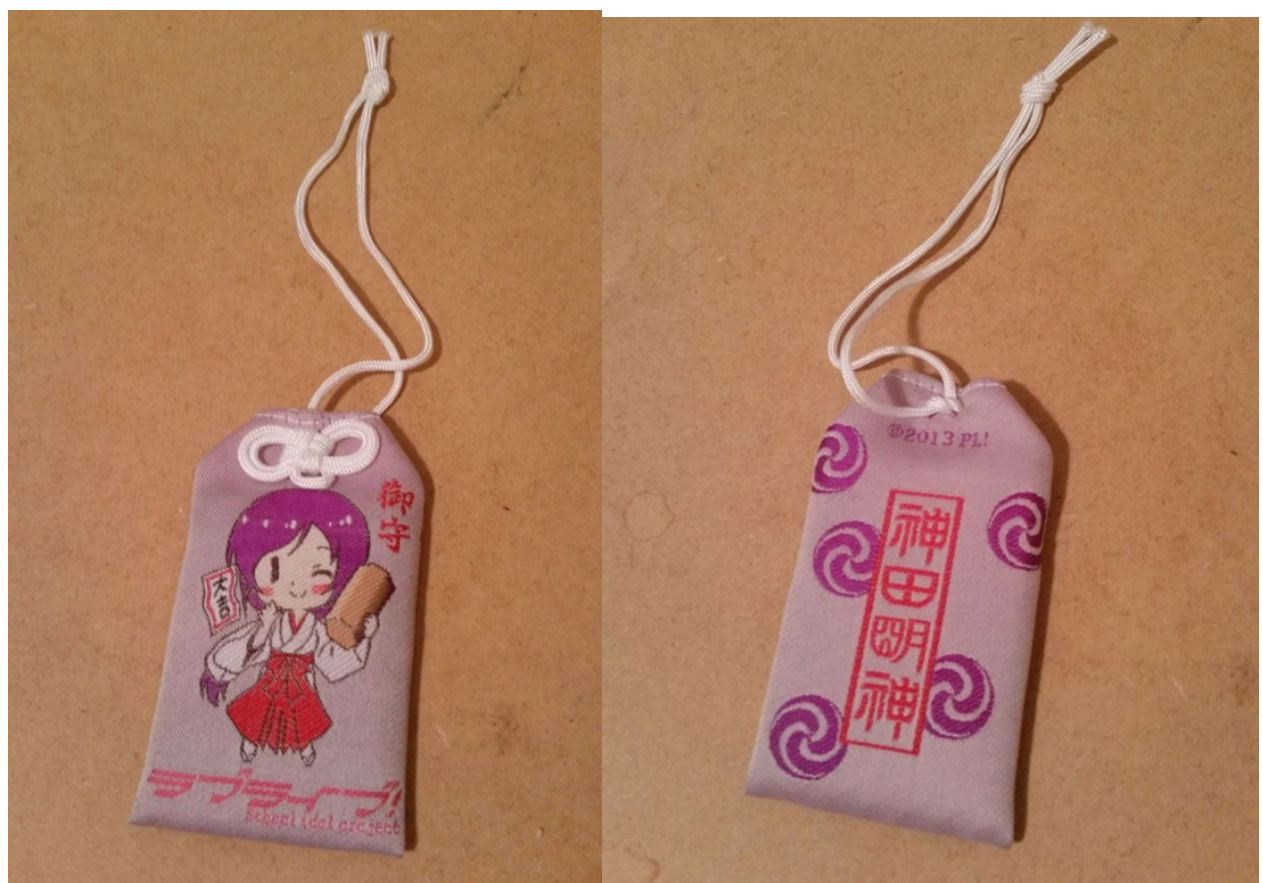

Figure 4.24. Phelps, Molly. "Nozomi omamori (front and back).” 2016. JPEG file.

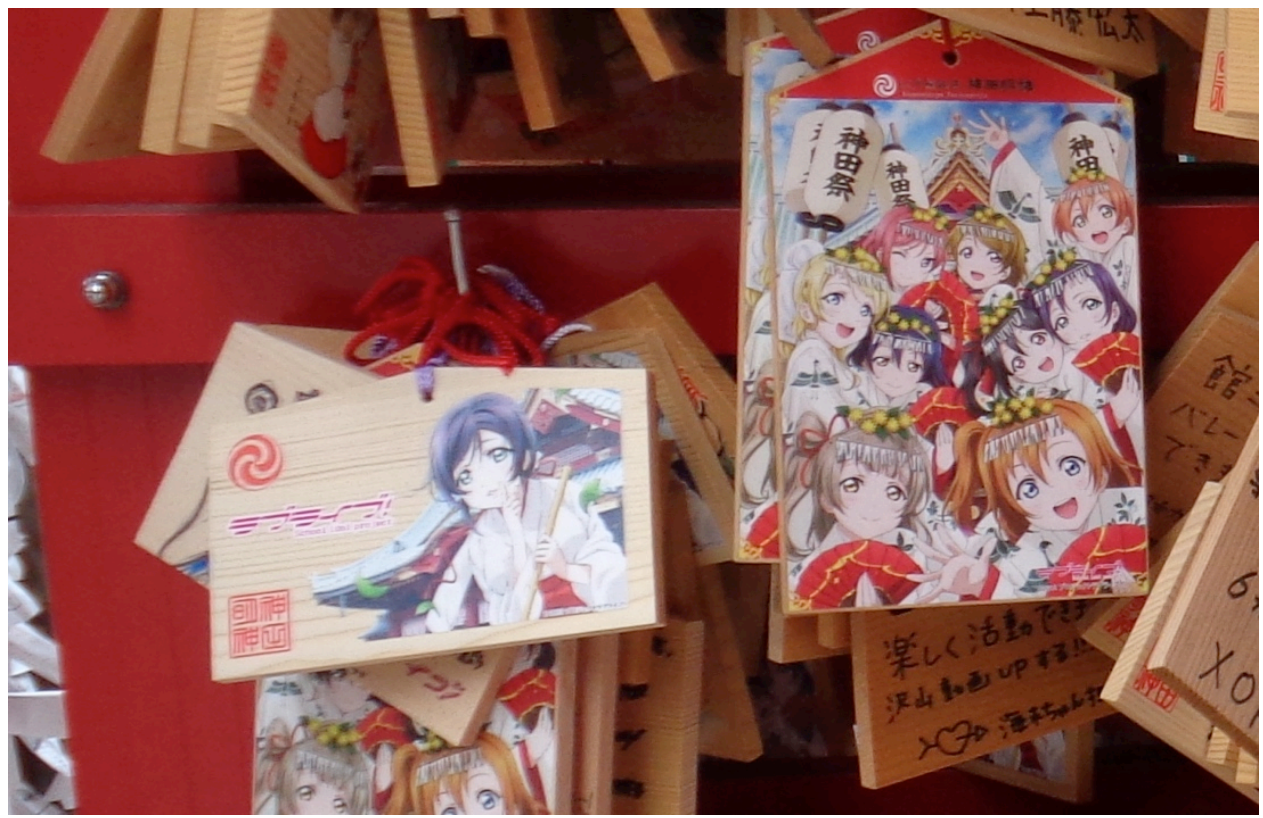

Figure 4.25. Sheehan, Kendra. "Officially Licensed Ema featuring Love Live!” 2016. JPEG file. 


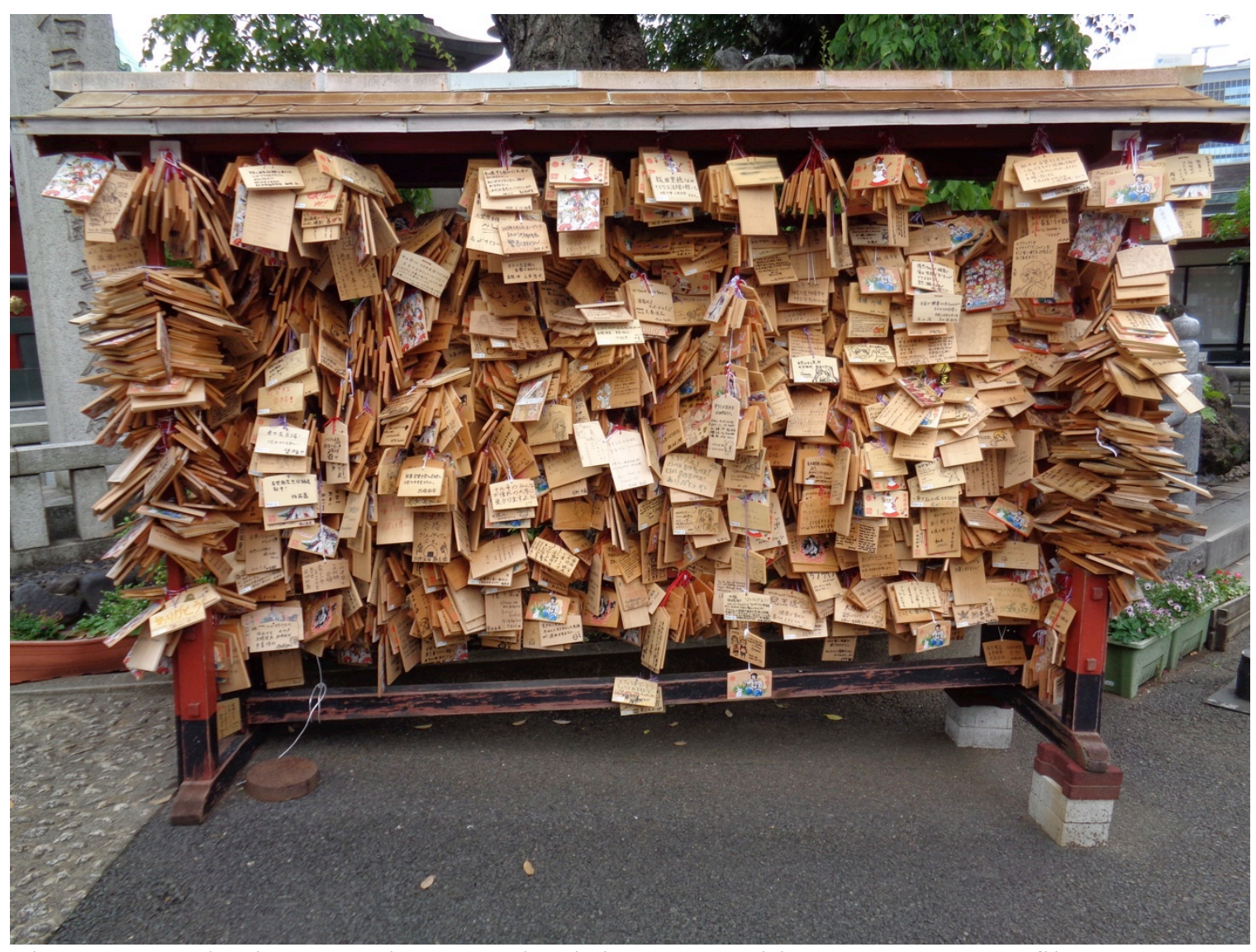

Figure 4.26. Sheehan, Kendra. "Kanda Shrine Ema Tablets.” 2016. JPEG file. 


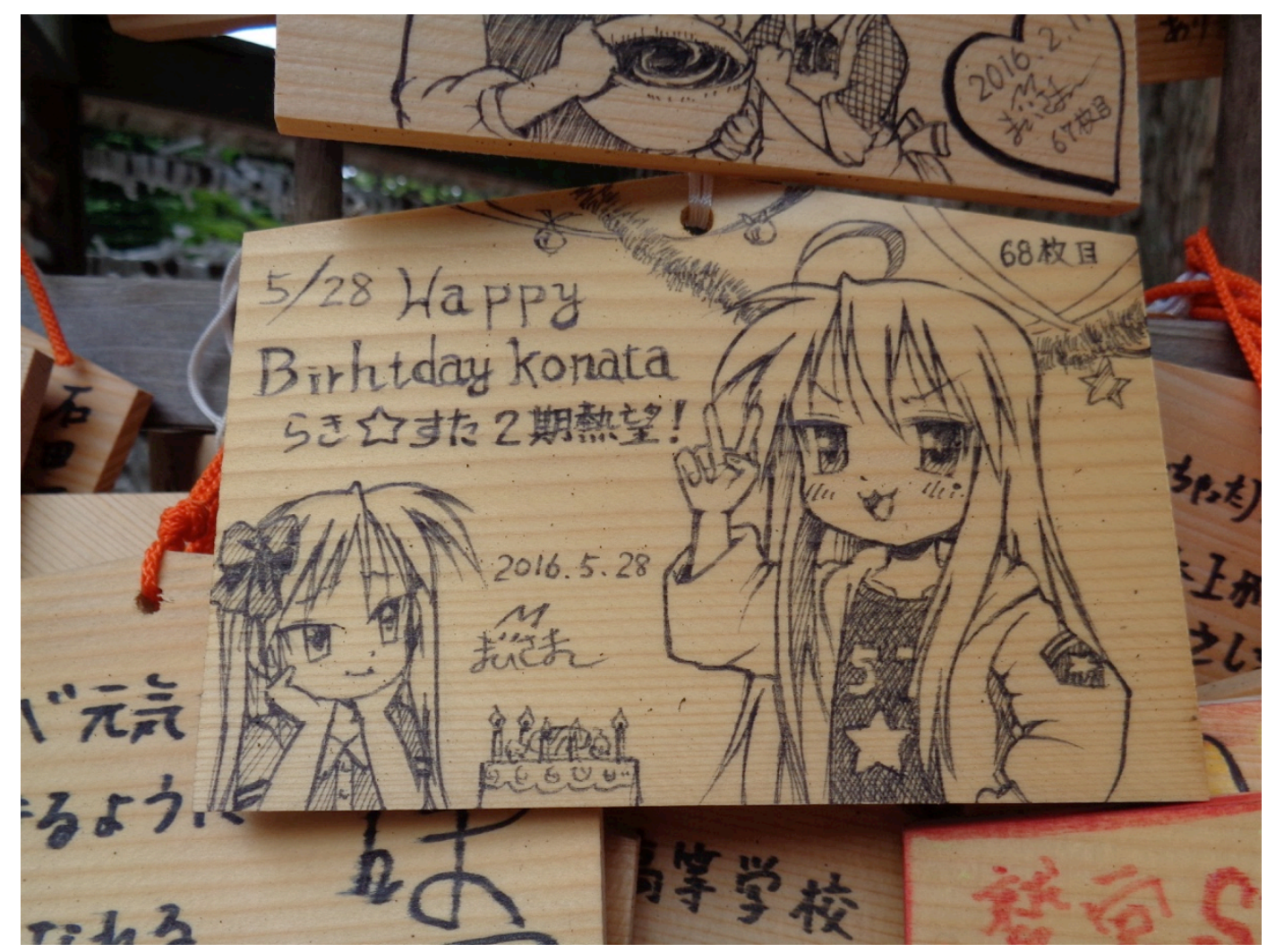

Figure 4.27. Sheehan, Kendra. "Ema from Washinomiya featuring Konata (right) and Kagami (left).” 2016. JPEG file. 


\section{APPENDIX B}

These fieldnotes were transcribed from notes compiled over the course of a month in Japan. There were no recorded interviews or other identifying information gained from those who were spoken with during the month. However, some conversations and observations of those spoken with were hand recorded in a notebook that is secured in a file cabinet that can only be accessed by the investigator. The notes are organized by day, city or location, and time is given when possible, but typically identified as "morning," "afternoon," or "evening."

\subsubsection{6 (Sunday) - Tokyo, Osaka, and Nara}

Late morning - Arrived at the Narita International Airport in Tokyo and went through customs. There were numerous illustrations and anime style mascots and signs all over the airport. There was also an airline mascot who was an anthropomorphic airplane. Many cities and prefectures in Japan have anime style mascots, but I have not seen Tokyo's yet.

$\underline{\text { Afternoon }}$ - Arrived Itami Airport in Osaka. There are many neon signs and advertisements with anime style characters. Took a chartered bus to Nara and noticed there were many ads with various mascots who were familiar and unfamiliar. Late afternoon and evening - Arrived in Nara and was surprised to see how many shops line the streets just across the street from the JR Nara Station. There are many cafes and restaurants as well. Surprisingly there are many signs in English. There are lots of images of an anime style anthropomorphic deer. His name looks is Roku and his cute face seems 
to be on everything. A shop keeper near the hotel explained, in very good English, that he is the unofficial mascot of Nara, the real city mascot is Sento-kun who is a little boy with long earlobes, deer antlers, and who looks like a cartoon version of the Buddha.

Apparently Sento-kun is not very popular. His appearance is a bit unsettling.

\subsubsection{6 (Monday) - Nara}

Morning and afternoon - Toured the city and became familiar with the area, location of train station, and so on. In the Higashimuki shopping arcade, there were many posters with anime characters, gachapon machines (several with Buddhist figures like Bodhisattvas or replicas of statues of the Buddha himself), and general touristy type shops outside of the shopping arcade. Many tourists are in this area. The Lawson Convenience stores have manga in the windows and various advertisements for Japanese pop culture themed items. Love Live! and Rilakkuma. The 7-11 had similar displays with manga situated firmly in the windows as well. Nara's mascots, Sentokun and Roku are plastered everywhere, such as vending machines and posters. There is also a NaraRanger (in the vein of the Super Sentai) and a police mascot of an anthropomorphized deer.

Evening - Local arcade on the same street as our hotel, the Nara Washington Hotel, has a first floor of claw or UFO machines that are mostly filled with characters from anime and manga, notably Love Live! and Osomatsu-kun. The second floor was filled with beat and rhythm games, third floor was gambling, and the fourth floor had fighting and shooter games. Many of the occupants looked like stereotypical otaku. There were some that were skinny or overweight, and a bit unfashionable compared to the rest of the people in Nara in the restaurants, cafes, and shopping arcade. A couple of young men had backpacks covered in keychains and buttons of various female anime characters. There 
was a lot of men, mostly young looking and maybe no older than their mid-twenties playing the Final Fantasy Dissidia game. I tried to strike up conversation in Japanese with one young man who was waiting for his turn. I asked about his interests, such as his favorite anime or manga series. He said he liked anime and that he loved Love Live! I asked who his favorite character was and he became very quiet. I thought maybe I insulted him and was about to leave, but he said he really liked Nico and struck a pose that the character does. In response to my asking why, he became quiet again and said because all of the girls are cute, but she's happy. She makes him happy. He then showed me a figure of the series that he had won earlier, as well as a keychain with Nico and a wallet chain with the pop idol group's logo. Some of the other patrons ignored me or would respond that they didn't speak English despite my speaking in Japanese. In addition to the young man I spoke with, four other young men, in their twenties or so, said that they liked anime, particularly Love Live! because the girls were cute and energetic.

There are many vending machines and convenience stores around the area. It seems like there is at least one vending machine every 20-30 feet or so. The drinks are priced very reasonably, with bottled water being the cheapest (¥100-110). Everything here is convenient and disposable.

\subsubsection{6 (Wednesday) - Nara}

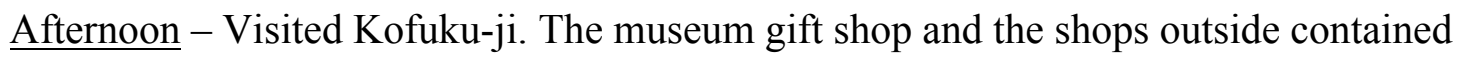
themed anime/pop culture type of items. Keychains, gachapon machines with Buddhist figures. I inquired as to whether the pop culture type of items were very popular and was 
given an affirmative answer by all those I asked. The response was also often followed by because it was cute.

Evening - Visited Aeon Mall. It was a bit like a Macy's, Sears, and Kohl's rolled all into one - essentially like a large department store with each floor dedicated to something else. There was a food court and grocery store downstairs with an area devoted to gachapon machines to the side. There were gachapon from anime and manga, Snoopy, Robots, and other miscellanea like succulents or samurai armor. I tried starting a conversation with a young couple in their twenties about the gachapon. They said everyone liked gachapon and showed me a couple of keychains they had gotten together from a machine at Kasuga Taisha - I think they were on their honeymoon. I didn't recognize the characters but they were dressed like miko from a Shintō shrine. There were also some junior high students milling about but I did not speak with them because they were under 18.

\subsubsection{6 (Thursday) - Nara}

Morning and afternoon - Visited Todai-ji, Sangatsudo, Nigatsudo, and Kasuga Taisha. Lots of tourists, mostly Chinese, school students, and Western (i.e. European and American) tourists. Shops, vending machines, and gachapon were scattered throughout these areas which were temples associated with Buddhism and Shintō. Rice crackers were sold to feed the many deer that milled about Todai-ji and Kofuku-ji. It appears that every temple has a gift shop area with amulets, charms, and other "touristy" type things for sell. Some of the charms are specifically made and bought for things like putting in your car, passing a test, and love. Near the gift shop located near the outer gate exit of the Todai-ji compound, is a gift shop that has many Roku items, as well as some items with 
Hello Kitty and Shingeki no Kyojin characters. I tried explaining I was surprised to see these characters at the shrine and a shopkeeper in her thirties laughed and said that they were popular. I asked if otaku bought the items and she explained that everyone bought things. I'm not sure she understood that I was asking specifically about the otaku, but to be fair she was busy running the stand.

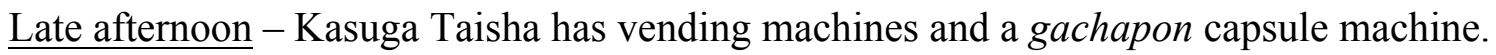
The capsule machine has miko and a nun key chain. The miko is not surprising as this is a Shintō shrine, but the nun key chain is a bit surprising because it's definitely a Christian symbol. Interestingly enough, most of these shrines seem to have no problem selling cute items.

\subsubsection{6 (Sunday) - Uji}

Morning and afternoon - Visited Byodoin. There was a matsuri with many working class people putting up stands. They were dressed in the Japanese equivalent of blue collar workers, they wore coveralls, cargo style pants, tank tops, tabi-style shoes, talked roughly, smoked openly, and many of them had dyed hair turning their hair an orangish blonde or reddish brown. Several of my students and I walked around the small town looking at the various stalls which had things like video games, anime/manga character items (keychains, plush, etc.), and airsoft guns, in addition to the numerous food stalls. Tried speaking to some of the people working the stalls, many of who were in their twenties or older, and they all mostly responded that everyone bought things there, especially children and teens. They said that some adults got really competitive to win anime figures and things like that but that they were usually still polite. When I asked 
about otaku, the stall workers repeated that lots of people bought or browsed through things.

In a shop off of the main street where the matsuri is being held, there are smaller shops. The city mascot Mayumaro was featured on many items in the shops. In one shop, I asked about Mayumaro and what he was exactly, if he was an egg, a youkai, and so on. The shopkeeper, an elderly woman in her sixties seemed a bit confused at first and admitted she didn't know, but that he was cute. Cute seems to be the most popular thing that many of the Japanese I speak to are concerned with. I checked online using free wi-fi from a cafe and found that he was supposed to be a silkworm cocoon. Visited one of the oldest Shintō shrines, the Uji Shrine, and saw a baby dedication ceremony and a wedding. Many people attended the wedding and it was raining while the sun was out, which in Japan is very auspicious as the saying is that the "kitsune is getting married" which connected to an old folktale. The wedding guests were dressed in suits and formal wear and the bride and groom wore traditional kimono.

The baby dedication had fewer people and was clearly more of an intimate family event. The parents were accompanied by who seemed to be both sets of grandparents to the young child. This shrine is adjacent to the Ujigami Shrine, which is connected to the early clan system of clan kami. The children are brought here after they are 30 months to 100 days old and have their first shrine visit where they are registered with the shrine. The baby is accepted as a member of the community and thus becomes an ujiko. The family is dressed in what could be called Sunday best in the United States. There was also a gift shop near what served as an entrance and exit. Miko were running the shop and 
there was a very clear sign that said no photographs with an image of a camera with an "X" through it.

\subsubsection{6 (Monday) - Tenri}

Morning and afternoon - Visited Tenri Elementary School and Tenri University. Spent the day with assigned Tenri students who would acts as language interpreters and who got to practice their English with our group. Our interpreter was very kind and patient. I spoke with her in Japanese and in addition to talking about the area, elementary school and college, I got to inquire about otaku in English - as this was beneficial for both of us. I asked what she thought of the word. She seemed surprised and explained that many people don't look highly upon otaku, especially if all they do is play video games, watch anime, and things like that. This student explained that it was not good to be an otaku and insinuated that it was immature. I also had the opportunity to speak to two of the teachers who spoke English and they both said the students really liked anime and manga. Clearly there is a difference between liking anime and being obsessed with it. The children are also young so it is possible that they are not considered otaku until they reach middle school, which seems to be the case because that is when most social groups and clubs are formed and students begin to explore their interests. I avoided asking about religion because Tenri is associated with the Tenrikyo faith. Tenrikyo is a shinshukyo (new religion) that originated in the $19^{\text {th }} \mathrm{c}$., founded by a woman (Oyasama), and is a modern Shintō sect in Japan. At lunch, the students all prayed before the meal and again at the end of lunch. Nearby is the large main Tenrikyo Temple where we observed many junior high and high school students praying before evening classes. 


\subsubsection{6 (Saturday) - Nara}

Morning - Nara Deer park observing tourists visiting the deer and on their way to Kofukuiji or Todaiji. Many students that walked by have anime and manga key chains and buttons on their backpacks. I ask one group of students' teacher if all of the student's like anime and manga. She seems surprised I know what anime and manga are and answers affirmatively. I ask her about otaku, which again, she seems surprised I know about, and she says that adult otaku are not very well liked because they should have grown up. She said that she thought students don't worry about being labeled an otaku until they are around 15 and 16 . I asked why and she said it was because then you are more concerned with being "kuuru" or cool. I did not talk to her long because the kids were clearly on a field trip and I thanked her for her time.

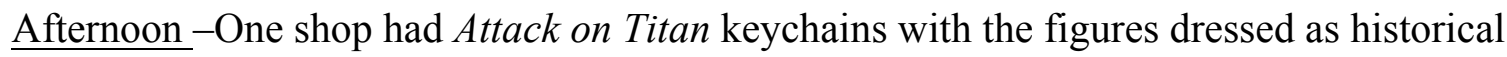
and religious figures. I was not allowed to take photos and noticed that many gift shops did not allow photos to be taken. The shopkeeper with the Attack on Titan merchandise said that she sometimes had college students that were from out of town buy anime themed things. I inquired if she thought they were otaku. She laughed at that and said that you can tell otaku because they are not fashionable or "hansamu" (handsome).

Evening - Went to Lawson's to get dinner and noticed a young woman browsing the manga in front of the store. I tried to catch her attention by also browsing the manga, because many Japanese seem surprised that people outside of Japan know the language, read manga, watch anime, and so on. She finally smiles at me and I try to start a conversation. The most I get is an affirmative nod to my comment that manga was popular in Japan. I have noticed that it is very difficult to start conversations with 
strangers here and I know most of it is because I am a stranger and a foreigner. Also, I can't always be fully certain of true responses because of honne and tatemae or true face and façade - They may be giving me the answers that they think I want to hear because I am a foreigner and are practicing tatemae. Honne is their true feelings and thoughts whereas tatemae is the behavior and opinions that are expected, especially when in public. I will continue to try.

\subsubsection{6 (Sunday) - Nara}

Morning - Lots of the shops in Nara have the Buddhist themed gachapon (capsule machines) out front where you can buy a capsule with a plastic/PVC figure for $¥ 200-500$. I have seen more Buddhist themed items but I believe that is due to Nara's biggest cultural attractions being Todaiji and Kofukuji, which are both Buddhist. The city's mascots Sento-kun and Manto-kun are also Buddhist in nature. Surprisingly one of the home stay moms I ran into this morning said that her grandfather had immensely dislike Sento-kun. She was a bit chattier than most of the Japanese that I have met, possibly because she knows English and was very happy to practice. She explained that Sento-kun was offensive. This was very interesting because many anime and manga use Buddhist themes and ideas. There is a series about the Buddha and Jesus living in modern day Tokyo. She struggled a bit to explain why but said that it was because Sento-kun looked like the Buddha with deer antlers and her grandfather felt that disrespected the Buddha. This was the first time I had heard such a thing but I believe it would be similar to Jesus being depicted in a childlike or exaggerated manner and Christians becoming very upset.

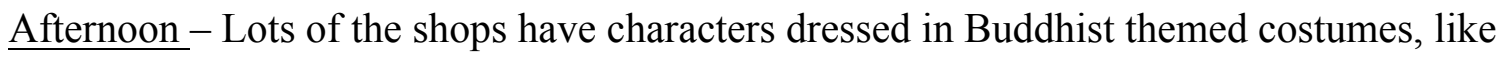
the Doraemon keychain where he is dressed like a green Buddha statue, or dressed in 
historical period clothing, lots of popular anime/manga franchises with characters dressed in things like Shinsengumi outfits or samurai armor.

\subsubsection{6 (Monday) - Tokyo}

Morning - On the Shinkansen to Tokyo, we have passed numerous ads featuring anime style females trying to entice customers, cute anime style anthropomorphic animals doing the same, and various anime series promoting products and upcoming movies. There is an anime styled mascot for everything. Each newsstand at the station also has manga to purchase. Kanda station seems to have the most advertisements because it is in Tokyo and it is close to Akihabara. Tokyo is a bit like New York, just with more cartoons and comic styled artwork on ads, posters, and signs. As with Nara, every convenience store we have passed has its manga on display in the front windows.

Afternoon -There are numerous ads in Shibuya, which looks similar to Times Square in New York. There are animated ads playing next to and after live action ads. Many of the shops in the area consist of trendy cafes, clothing stores (including skater themed clothing), Tower Records (a music CD store), McDonalds, and more. Everything here is features more high-end fashion that what I saw in Nara. The Tower Records was very interesting as it has not only CDs and music, but gachapon machines on nearly every floor. There was also a display place for music and soundtracks from various anime which was not surprising because most if not all series have an opening and ending theme song by a pop idol, pop group, or other well-known musical acts. Upon leaving Shinjuku, I met a Canadian tourist who chatted with me on the way back to the Kanda Station. Although she was not Japanese, I asked her about what she had noticed about the otaku in Tokyo. She was a self-proclaimed "otaku" back home but said she was surprised to 
discover it was not exactly a good thing in Japan. She was surprised when Japanese friends brought her to the Kanda shrine and she saw Love Live! merchandise there. I told her a bit about my dissertation and what I was hoping to find there and she confirmed many of my suspicions. She said her friends were surprised she recognized the series and that they were not religious in anyway, but one of the girls had a job interview of some sort coming up and wanted to get a luck in business charm from the Kanda shrine. The Canadian girl showed me her photos she took and suggested things to look for, including the stairs to a side entrance of the shrine that is used in the anime Love Live!

Evening - Despite it being past 2100 (9:00 PM), I went back out to Akihabara, which is about a 15-minute walk from the hotel. Akihabara is the so-called "mecca" for otaku. It did not disappoint. As I got closer there were billboards with anime girls draped over one another, signs with anime girls winking and holding food, and nearly every poster or sign had an illustrated young looking female on it. There are also many advertisements for maid cafés.

Once I got into Akihabara, I was not surprised to find a large billboard with women dressed in maid uniforms, all smiles, and open hands welcoming me to Akihabara. There seem to be arcades, much larger than the one in Nara, in every other building or so, and they all had the same Love Live! merchandise in the claw and UFO machines on the first floor. Each arcade had a similar set up to the one in Nara, although some of them had the bottom two floors stocked with claw/UFO machines, and then rhythm games, and so on. However, it was surprising to see that each arcade had the same Love Live! figures and prizes, considering that the arcades were not owned by the same companies - for instance, Taito and Sega. This truly speaks to the popularity of this series. 
The other observation I have as I got closer to Akihabara, the people started to change as well. People are no longer dressed in the haute couture or high-end fashion that I saw in Shibuya or the area around my hotel. There are a lot more t-shirts, track jackets, and what I now clearly understand to be "unfashionable" pants here. Most of the people I have seen in Japan to this point have worn neatly pressed and skinny style jeans or khakis that have been rolled up at the bottom - what we would call "hipster" back home. The young men here have awkwardly fitting pants coupled with out of date shoes - they look like the New Balance tennis shoes that are jokingly referred to as "Dad" shoes in the U.S. Many of the young men are dressed in a way that many Americans would jokingly refer to as "dad clothes." They have large backpacks that stick out and numerous key chains of anime girls winking, posing, and holding various objects that cover their bags, along with buttons of other animated females. In one shop that sold manga, anime, video games, and other miscellanea, I saw young men who were studying the goods on the shelves. One young man I observed held a figurine box close to his face, turning the box around and closely inspecting it. He was thin, his hair a bit messy and longer than I had seen so far, most young men had shaved heads, gelled hair, or trendy haircuts. His shirt was wrinkled, his jeans were a bit short, and he had on white New Balance shoes. His backpack looked like it was nearly full to bursting, and I have read that this is often because of how much merchandise the otaku buy. He definitely meeting all of the stereotypical criteria for otaku. I waited until he had seemed to make a decision on the figurine and when he noticed me I smiled and said hello. He immediately seemed to panic (his eyes widened and he looked around him) and went down a nearby aisle after nodding at me. I tried speaking with several other young men in the shop but they all had similar responses or 
ignored me completely. Most notable about my time in this shop was that I was the only female in the shop during the hour I spent in there. Many of the figurines were of busty female characters. There were also body pillow covers located near the cashier, but a no photos sign was posted there and throughout other places in the store.

Outside of the shop and scattered throughout main strip of this area, were young women dressed in maid costumes and handing out flyers. They spoke in higher pitched and cutesy voices trying to get passerby to visit their maid cafes. Some of them ignored me, and only one out of the seven or so I passed, actually acknowledged me. She gave me a flyer and tried to walk me over to the door that lead to the café. When I asked her questions, her responses were mostly deflections and encouragements to get me to go inside. I gave up trying to speak with her, because she was working and I realized that I could be interfering with her working and keeping her from gaining customers. Even if I did visit the maid café, there are no photos allowed, and I felt certain that they would not let me take notes. Mainly the cafes are there so that the customer can be treated well and forget his worries that lie outside of the café. The maids play games with the customers, you can pick which maid you want to wait on you, there are various prices for varying levels of service (like taking a photo), and so on. I don't think the maids would tell me anything other than a scripted response to my questions and it would be rude of me to try and interview them while they are working.

I also noticed that there are some shops with adult videos where the customer can choose the AV actress they want to watch. The more I walk around Akihabara, the more I notice that nearly most, if not all, of the images in the area depict women striking sexy poses, nearly nude or in bikinis, and it is very clear who the intended recipients of these images 
are - men. The Love Live! figurines have their skirts designed in such a way that you can see their underwear.

\subsubsection{6 (Thursday) - Washinomiya Shrine and Kanda Shrine}

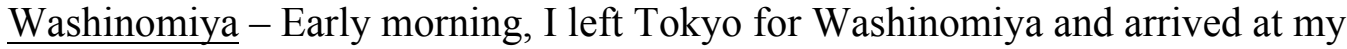

destination at roughly 0925AM (the train ride is about an hour and fifteen minutes away depending on the trains you take). From the station in Washinomiya, the shrine is only about a five-minute walk. The area is very rural. The further I got away from Tokyo, I noticed that the advertisements and landscape drastically changed. There were very little illustrated ads and pop culture themed posters or signs in the Washinomiya station. The landscape itself was mostly empty fields, older looking traditional style houses, and rice paddy fields. Once I got closer to the shrine, I saw more pop culture and illustrated ads, but still nothing compared to Tokyo. There was a shuttered building, a restaurant, with hand painted images of the characters from Lucky 2$\}$ Star on it that read "Welcome to Washinomiya". Walking back towards the shrine and its main entrance where the torii is, I saw a small banner with the Hiiragi twins dressed as miko fluttering from a streetlight/utility pole in front of the torii. A few feet away outside of the torii on the ground was a smooth black stone that resembles an ema with the sisters on it as well. In front of the stone was a wooden basket with some Japanese yen thrown into it. The torii itself was faded and was not the vibrant vermillion red that I had seen at other Shintō shrines in Japan. This shrine is very old and many of the trees nearby are covered in moss and very large. The town was very quiet and could be termed "sleepy," as the several hours I was there nothing seemed to be open and much of the surrounding area was either 
houses or fields. The only Japanese I ran into at first were elderly Japanese out for a walk with friends (no more than 3 or 4 to a group) or walking their dog.

The shrine itself is small but situated in a small wooded area. After walking through the torii, there is a public restroom to the left with a Coca-Cola Vending machine nearby. In Japan, I have become used to seeing various vending machines on temple and shrine grounds. In the U.S., I do not think vending machines on church property would go over very well. On the left as one heads towards the main shrine, is a pond that is roped off where supposedly a dragon god rests. The shrine grounds are very quiet as right across from the pond a tree that is surrounded by ema tablets. The tree has three panels for omikuji, fortunes from having one's fortune told at the shrine, and the other three are for ema, wooden prayer tablets. There are many tablets with the characters from Lucky 2 Star drawn on it, several say "Happy Birthday Konata!" and include a hand drawn image of her on it in addition to the other three main characters from the series. There are also some ema that depict characters from other franchises, some that I recognize, such as Attack on Titan, and others that I don't. A few tablets include anime females on the tablet that look as if they were officially licensed products. What I mean is that the trademark and copyright info is at the bottom right corner of some of the images. However, when I visited the gift shop, I could not see any such ema for sale. Washinomiya shrine surprisingly seemed to have no anime themed items for sale, despite the outside of the shrine having a café/restaurant that was only several feet away that sold Lucky $\succsim$ Star themed items. Though, one thing that was obvious and more prominent than some of the other Shintō shrines I visited was a rather large sign, which prohibited photographs being taken. I began to understand why as I noticed the miko working the gift shop. Miko are 
often depicted in anime and manga and I could see why that could be problematic for the young women working at real shrines. Their job is fetishized and commonly depicted in

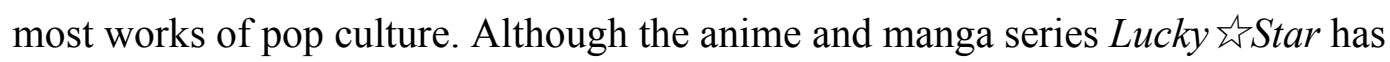
brought many people to visit this shrine, and despite newspapers reporting that the head priest said that they (in reference to the otaku) were polite and respectful, I could see how troublesome it may be for the young women who work at the shrine. It is very much a living shrine and as I sat and observed visitors to the shrine, many of them were older, from their 40 s to their 80 s. I watched as several people visited each small altar on the property, disappearing into the wooded areas and returning 15 minutes or so later to pray at the small altar about 40 feet or so away from the pond area. They were quiet and solemn in their prayers. One can usually discern the Japanese visitors to the shrines in Japan because they are often quiet and solemn compared to the many tourists I have seen who have their cameras out and who never seem to stop and pray at the altars. One elderly woman noticed me sitting on a bench watching everyone and she smiled at me. She spoke some English and asked me if I was American. We talked and I mentioned that the shrine was very quiet. She confirmed my suspicions about an off-season and said that during the Haji-sai festival the town is very lively. The Haji-sai festival is in autumn (September to be exact) and it certainly explained the quiet in the area. I asked her if she had seen Lucky «ॅStar and she laughed at me and said her grandson had tried showing and explaining it to her. I asked if she thought he might be like an otaku. She said he was in college and like cartoons but that he was studying hard. I was not sure if that was a deflection or if there was a greater implication. From what it sounded like, he was preparing to graduate and was looking for work. She said he had a girlfriend, then asked 
me if I was looking for a Japanese boyfriend. The rest of our conversation resulted in her asking me about America and what I thought of Japan. She eventually had to leave and I thanked her for her time. After she left, I tried unsuccessfully to speak to the miko and shrine attendants.

Around 1107AM I noticed two young men outside near the torii. They stood out because one bespectacled young man was very slim and dressed in a pink button down shirt with dark blue jeans and his friend was husky and dressed in a baggy orange t-shirt with dark blue jeans as well. They resembled some of the otaku I had seen in Akihabara. They immediately stopped in the parking lot of the shrine and took a photo of the torii. The torii is prominently featured in the opening of the Lucky $\downarrow$ Star anime. Both young men had on large backpacks. They both smiled and laughed as they took photos and were very excited. I realized that they were possibly on an anime pilgrimage. Surprisingly, neither had the telltale charms of otaku on their backpacks. Once they walked past the torii, they immediately headed over to the tree surrounded by ema. They read and examined many of the ema. Every now and then they laughed at the tablets and pointed to them. When one of the miko crossed from the gift shop area to one of the nearby buildings they became very excited and the young man in orange tried taking a photo. As they walked further into the shrine grounds, I noticed another young man approach the torii. He was dressed in a green polo shirt and khaki pants. I watched him swing his backpack around and he removed a couple of keychains and pulled out a camera. He also took pictures of the torii and smiled the whole time he was doing it. Similar to the other two young men, he immediately headed to the ema tablets. Smiling, chuckling, and frowning at some of them. I watched him go to the gift shop and purchased an ema. I tried speaking with him 
but he smiled and apologized saying he did not speak English although I was talking to him in Japanese. I tried speaking again and he paused to listen to me. The most I could get out of him in conversation was that he did like Lucky $\succsim$ Star. It is very hard to get interviews, especially as a foreigner. As I left the shrine around 1340PM, three more young men passed me, talking about the shrine and pointing to it excitedly when it came into view. Clearly, while Lucky $\lesssim$ Star aired some time ago, it is still influential and the allure of the series causes otaku to still visit the shrine as part of an otaku pilgrimage. Kanda - Arrived in Akihabara around 1428PM. As I walked to the Kanda Shrine, I realized immediately that it was very different from the Washinomiya Shrine. The Washinomiya Shrine was in a sleepy town out in the countryside whereas the Kanda shrine is in the middle of Tokyo, surrounded by tall concrete buildings and right near Akihabara. It was much busier and I saw many men and women in business dress sitting on benches located on the shrine grounds, some praying near statues of the kami of fortune or near the main altar, and some sitting on a small elevated wooden platform and looking as if they were meditating. Similar to Washinomiya, the people praying performed the traditional form, clapping hands and bowing. They wore serious expressions and it was clear this was a serious visit. Compared to Washinomiya, the Kanda torii was much different, it was a made of metal, there looked to be a patina on the torii, much like the government shrines of the WWII period when Kokka Shintō was prominent. There was a gift shop to the left of the open area just past the torii and it sold various items inside, including drinks and snacks. Some gimmicky souvenirs with samurai and ninjas adorning pens and so on were available for sell, and other items that were more serious, like omamori. There is a fancy gate just after the torii with statues of 
guardians nearby on either side of the gate. Near this gate is a sign in English, Chinese, and Korean, which explains the importance of this shrine. There was nothing like this in Washinomiya. The sign notes that the shrine is one of the oldest shrines in Tokyo, and giving a history of the shrine itself and the deities enshrined there. It also notes the matsuri associated with the Kanda shrine.

As a larger shrine, there are more than one racks dedicated to the ema here. There are at least four areas that I count, spread out in the corners of what could be considered a quad or courtyard of the shrine, that are dedicated to just ema tablets. The racks are long and covered on both sides, and several of them have tablets hanging from the ends. Surprisingly, there are official Love Live! ema sold here, with two different styles. One style features Nozomi who is a miko at the Kanda shrine in the anime and the other style features all of the girls dressed in kimono and holding fans. Some of the ema read "thank you!" or reference an event within the anime known as "Final LoveLive!" One area has these ema racks set up so that it forms a tunnel of sorts and when you walk through it there are ema surrounding you on both sides and hanging above you. It is overwhelming. Right next to the gift shop is an actual building with a little café that also of course has souvenirs and other items for sell. The main gift shop outside is run by the miko and again, there are no photographs allowed. There is also a gachapon nearby with Shintō themed figures and a small replica of the Nozomi ema. I did not notice and gachapon outside of Washinomiya or outside of the shrine.

Different from the Washinomiya shrine is that there are numerous products with Love Live! character Nozomi on them, including an omamori charm, as well as the two styles of ema. There is a poster nearby with the Love Live! characters on it, within the temple 
grounds, whereas Lucky $\lesssim$ Star themed things were outside of the shrine. The large ema with all of the Love Live! characters was $¥ 1500$, which was much more expensive than some of the ema at Washinomiya and other shrines. They also have charms you can place on your electronics or business card holder, a small ema with Nozomi for $¥ 1000$, the omamori with Nozomi was $¥ 800$, and other charms were much more affordable and the same price as the other shrines which was about $¥ 500-800$ but they did not have any of the Love Live! characters on them. This shrine is much busier and there were at least 15 visitors within the shine in the several hours I spent here. The miko here also did not speak with me unless it was when I was purchasing something. Many people come into the shrine, pray, and then leave. The young people I see come in and mill about. I notice more otaku here admiring and critiquing some of the ema. This shrine is near a bustling district full of consumers and has clearly molded itself to meet their needs, whereas Washinomiya was quiet and had serious visitors who came to pray and walk around, save for the otaku visitors I saw there. I did see some possible otaku taking photos of the stairs that are used in the Love Live! anime by the characters. They were not available to speak with me. Similar to the otaku at Washinomiya, they were either by themselves or in small groups of two or three.

Kanda Shrine is also unique to the Washinomiya Shrine because there is a sign posted, with English and illustrations, nearby that explain how to properly pray at the shrine. Washinomiya had the children's illustration of how to purify your hands and mouth, but it was written only in Japanese. Additionally, unlike the otaku at the Washinomiya Shrine, the otaku here look just like the ones I saw in Akihabara. They have numerous key chains and other pop culture paraphernalia that mark them as otaku. They seem more 
welcome at Kanda than at Washinomiya, because here they are right next to Akihabara and it is located in a city versus a rural town where the shrine does not use officially endorsed merchandise from pop culture.

Also noteworthy is that many of these shrines do not have tax on their items. Every time I have purchased something during my stay here, there has been an $8 \%$ sales tax. But at the shrines there has not been any tax or receipts given. It appears that the money the shrines make stay within the shrines themselves. Possibly similar to churches in the U.S.? Just outside of Kanda Shrine is a Lawson's convenience store that has a banner of IdolMaster outside of the store and inside.

Evening - I met a young woman who spoke fluent English and had lived in the U.S. for a year when she was a college student. She had heard me mention Kentucky to another person in my group and she explained that she had studied in Western Kentucky. She was very excited to speak in English. We spoke about the otaku and she said that many in Japan still look down upon them. They are seen as immature because they still cling to pop culture and ignore everything else. I asked her about other adults who read manga, watched anime, and bought pop culture items (like key chains, charms, and so on) but she assured me that it was different. It was moderation. The otaku are extreme in their obsession with pop culture. I was surprised she said obsession but she explained that it couldn't be described in any other way. I asked her about religion in Japan and she confirmed much of what I have read. Most of the visits are out of tradition rather than a religious duty. She said some people do take religion seriously, but that she had not met that many who did. I asked if she would date an otaku or closet otaku and she thought about it for some time. Finally, she said that she felt she would if they could be more 
normal. I asked what she meant and what did normal mean, but she laughed the question off. We spent the rest of the evening with her giving my group advice on restaurants and bars in the area.

\subsubsection{6 (Friday) - Hiroshima}

Late morning -Many images of the cartoon mascot of the Hiroshima Carp baseball team are plastered around the city. There are some religious symbols here and there, but they are mostly souvenir items with rice paddles because Hiroshima is supposed to be renown for their rice. The hotel has a small gift shop with themed items for the Hiroshima Carp as well as a Hello Kitty in baseball gear and traditional kimono. Most of the city is serious as this is the first city to be targeted by a nuclear weapon and to have the first city to be hit by an atomic bomb. The main tourist draws here are the Hiroshima Carp baseball team, the Genbaku Dome (AKA the Atomic Dome), and the Hiroshima Peace Memorial Park and nearby Hiroshima Peace Memorial Museum.

\subsubsection{6 (Saturday) - Miyajima Island}

$\underline{\text { Afternoon }}-$ Several of the shrines in this area actually sold Hello Kitty omamori for $¥ 500-800$, but as usual I could not take any photos because they were prohibited. As you head towards Mt. Misen, there were Buddhist temples that had Jizo statues wearing sunglasses, hats, and t-shirts (one statue had a Nike t-shirt on). There were also of course vending machines a couple of gachapon at the bottom of Mt. Misen. As we were leaving, we walked through a small shopping district to get to the ferry. I saw a golden Hello Kitty holding a rice paddle with a large Red Shintō torii behind her. Hello Kitty was maybe 2 or $2 \frac{1}{2}$ feet tall and the torii was at least 3 foot tall. It was very interesting and I managed 
to get a photo. A pop culture figure, known around the world, with Shintō themed items and symbols.

\subsubsection{6 (Sunday) - Himeji}

Mid-morning - Arrived in Himeji on the way to Kyoto. From the station exit you can see Himeji Castle. Most interesting however is the city mascot Shiromaru-hime (literally, "princess white ball”), a cute mascot that is a round white ball shape with the Himeji

castle on top of her head. Inside the station a person in a costume of the mascot came out and we took pictures with her. Images of this mascot were on the windows and doors of the tourism center located within the station. The main attraction in this area seemed to be the Himeji castle. Not unlike the other tourist sites we have visited, this one also had a gift shop that sold a multitude of typical souvenirs but also some that had religious themes. There were also recognizable anime and manga characters on various products.

\subsubsection{6 (Tuesday) - Kyoto}

Late morning and afternoon - Visited Kiyomizu-dera, a Buddhist temple. This particular temple had Hello Kitty omamori but the main draw was the womb tunnel. You pay $¥ 100$ or so to enter a tunnel that is associated with the Buddha's mother, and it is pitch black. As you move through the tunnel you come to a stone with light shining on it and the exit. The stone has the Sanskrit word for "womb" engraved on it and it is supposed to symbolize your rebirth. I also drank from the Otowa Waterfall which is supposed to bring fortune, but apparently each stream gives some benefit, such as longevity, success at school, and a fortunate love life. You are not supposed to drink from all three because that is greedy. There is also a shrine dedicated to a kami of love and matchmaking, the Jishu Shrine. There are two stones in front of the shrine, and if you can walk from one 
stone to the other with your eyes closed, it brings you luck in love. Many tourists visited this area and it was surprising if anyone could do it. You could have a friend help guide you but then that meant you needed an intermediary in your love life too. There are also multiple things sold nearby for luck in love. There is definitely a commodity of spiritual aid being marketed towards visitors but not all of the shrines use licensed pop culture figures to sell charms.

\subsubsection{6 (Wednesday) - Kyoto}

Morning and Afternoon - Visited Kinkaku-ji and Ryoan-ji. There weren't as many discernable gift shops although the streets leading up to both places had gift and specialty shops as well as restaurants and cafes. There is definitely a thriving economy that springs up around these temples and shrines once they become tourist destinations or renowned for some special thing. These shops that built up around these shrines/temples was also present in Nara and the other places we visited as well, but it's truly become clear as I visit each new place. The shops often have a blending of cultural/prefectural specific goods, pop culture themed goods that tie into some historical aspect, and typical tourist fare (like ninjas, samurai, and rental kimonos).

\subsubsection{6 (Thursday) - Kyoto}

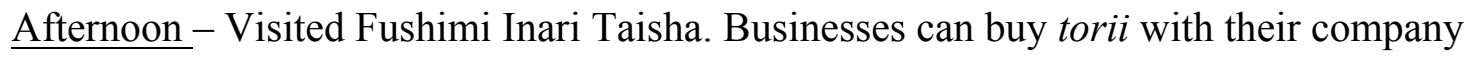
name on it for blessings for the year. They can buy small torii or large torii, the same size as the ones found in front of shrines. There are many souvenir stops and drink stops as you move towards the top of the compound. Some items include charms and key chains with foxes on them, as the Inari Taisha is the shrine to Inari, messenger of the gods who is closely associated with foxes. The shrine itself is also associated with business success, 
in addition to rice and fertility. Many business names were engraved on the large torii that they purchased. It's an interesting dynamic considering that it is free advertising and shows that the company is dedicated to tradition, which in turn is very important to Japanese culture.

\subsubsection{6 (Monday) - Kyoto}

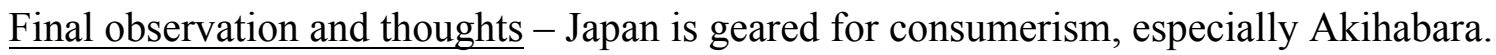
Women are dressed as maids and compete for passerby's patronage, handing out flyers and trying to entice the men that pass by. Advertisements are on TV, buses, subways, trains, and essentially everywhere. Many Japanese that I have encountered and know personally have pointed out the disposable culture of Japan. Rain umbrellas are often bought cheaply and left in stations or convenience store umbrella racks. Vending machines are scattered throughout cities, on nearly every street corner, in alleys, at temples and shrines, as well as mountaintops. Temples and shrines sell charms, wooden prayer tablets, and some sell items with licensed characters such as Love Live! and Hello Kitty, in addition to some charging an entrance fee. While the shrines/temples may not always use licensed pop culture items to make money for the shrine/temple, they do capitalize on pop culture itself as well as commodifying the "specialties" of the shrine/temple - whether it be luck in love or successful business. 


\section{CURRICULUM VITA}

NAME: $\quad$ Kendra Nicole Sheehan

ADDRESS: $\quad 1036$ West Indian Trail

Louisville, KY 40213

DOB: $\quad$ Louisville, KY - July 2, 1984

EDUCATION

\& TRAINING: $\quad$ B.A., Humanities

University of Louisville

2002-2010

M.A., Humanities, Concentration in Literature

and Religion

University of Louisville

2010-2012

Ph. D., Humanities, Culture, Criticism, and Contemporary Thought

University of Louisville

2012-2017

PUBLICATIONS: Co-author of "ClarissaBlogs: Narrative, Writing, and the Self." KAIROS. 19.2, Spring 2015.

Co-author of "Being an Ally." White paper.

2013

BOOK REVIEWS: "Patrick W. Galbraith, Thiam Huat Kam, and Bjorn-Ole Kamm, eds. Debating Otaku in Contemporary Japan: Historical

Perspectives and New Horizons." History: Reviews of New Books 44.6 (2016).

PRESENTATIONS: "Popular Culture as Upāya: Osamu Tezuka's Buddha and Nakamura Hikaru's Seinto Oniisan." Panel: "Monstrous: Taking Interdisciplinary to Task Via Rigorous Methodologies and 
Popular Culture." Presented at The Louisville Conference on Literature and Culture Since 1900. Louisville, Kentucky. 2014

"Taking the High Road and Adapting to Change." Presented at the University of Louisville REACH Tutor Training. Louisville, Kentucky. 2011

"The Japanese Cultural Obsession." Presented at the University of Louisville AHA Graduate Conference/RE Conference. Louisville, Kentucky. 2011

INVITED PRESENTATIONS: $\quad$ Film Moderator: “The Hidden Fortress (1958)." The Eleventh Annual International Film Series, The Intercultural Communication and the Department of Communication, University of Louisville. 2017

Film Moderator: "Metropolis (2001)." The Eighth Annual International Film Series, The Intercultural Communication and the Department of Communication, University of Louisville. 2014 